\title{
Two Wars, Two Narratives: A Comparative Study of AP's Coverage of 1982 and 2006 Israel-Lebanon Conflicts
}

\author{
by \\ Shahrzad Faramarzi \\ A thesis submitted to the Faculty of Graduate and Postdoctoral Affairs \\ in partial fulfillment of the requirements for the degree of \\ Master of Journalism \\ in \\ Journalism \\ Carleton University \\ Ottawa, Ontario \\ (C) 2014 \\ Shahrzad Faramarzi
}




\section{Acknowledgements}

Foremost, I would like to express my sincere gratitude to my advisor Professor Karim Karim for the continuous support of my study and research, for his patience, motivation, enthusiasm, and immense knowledge of the subject. His guidance helped me in all the time of research and writing of this thesis. Also, I would like to thank the rest of my thesis committee: Susan Harada, Klaus Pohl and Antoine Char. Special thanks go to former AP Middle East news editor GG Labelle, Special AP correspondent Charles J. Hanley and former BBC Middle East correspondent Tim Llewellyn for tirelessly providing insight into the workings of journalism. I am also grateful to fellow Carleton student Masoud Nematollahi for sharing his technical skills and creative input in the presentation of this thesis. I also thank my friends and former Globe and Mail colleagues Joan Ramsay and Wayne Walters for their stimulating discussions about the thesis and support in seeing it through. Also, I would like to thank my family: my brother Faramarz, sisters Nazanin and Maryam (despite her aversion to politics) for supporting me in this endeavor, my niece Farnaz Faramarzi for helping me transcribe many of the recorded interviews, and my grandniece Ava Shisheboran who kept me on track when I tended to detour towards procrastination. Lastly, I would like to pay tribute to Anthony Shadid, whose excellence in journalism gave me hope for the future of the profession, and AP photographer Anja Niedringhaus with whom I covered many stories in Iraq and who encouraged me to write this thesis, and whom I interviewed on Skype from Afghanistan for this thesis. Unfortunately they are no longer with us: Anja was killed in Afghanistan earlier this year; Anthony died while covering the war in Syria in February 2012. Their death is a huge loss to journalism. 
Table of Contents

Acknowledgements .........................................................................................................1

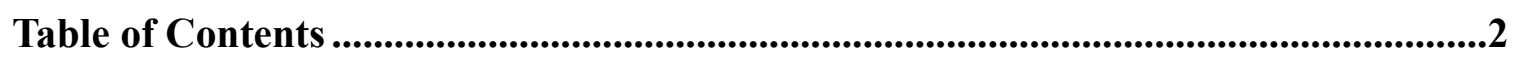

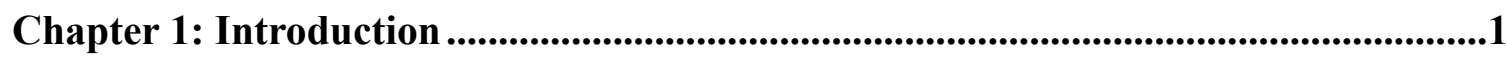

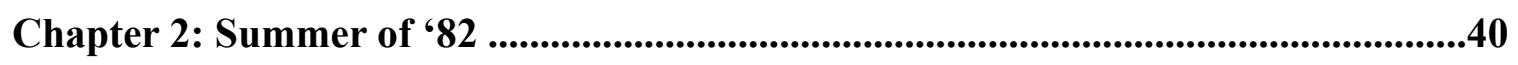

Chapter 3: Competing Narratives - 1982-2000 ...............................................................8.

Chapter 4: "War on Terror"

Chapter 5: Summer of '06 ...........................................................................159

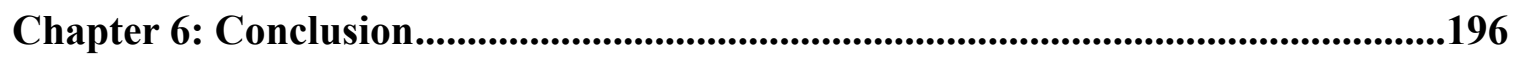

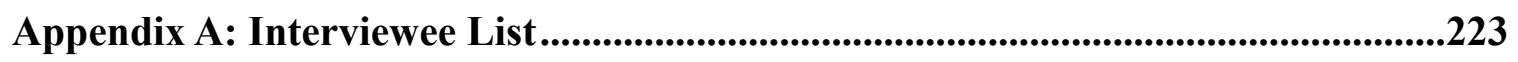

Appendix B: A History of The Associated Press ....................................................225

Appendix C: List of Internal AP Communications ..................................................233

Appendix D: Letter from Tel Aviv Bureau Chief Frank Crepeau to Sr. Editors.....235

Appendix E: Letter from Beirut News Editor Stephen Hindi to Senior Editors.....237

Appendix F: Some of the General Questions Posed to AP Interviewees ...................250

References................................................................................................................................251

List of Cited AP Stories .......................................................................................................254 


\begin{abstract}
This thesis investigates how coverage of Western mainstream media, with a focus on The Associated Press news agency, changed over more than two decades by studying and comparing reporting of two Israeli wars on Lebanon: in 1982 and 2006. The two wars represent a microcosm of media coverage of the conflicts between the same two countries decades apart. Israel's effective use of public relations campaign to regain its reputation in the international mainstream media following its 1982 invasion of Lebanon and following the massacre of Palestinian refugees there, coupled with America's post-9/11 "war on terror" narrative are at the center of the evolution of media coverage of the Middle East and conflicts there, including the 2006 war. This evolution in coverage of two wars is the main theme of this thesis is explored in detail; its effects are demonstrated throughout the chapters with academic evidence as well journalistic examples almost entirely through the coverage of the AP, one of the world's largest international news organizations, whose enormous influence forms the narrative. The striking difference between AP's coverage of the two Israeli wars on Lebanon reflects the extent of the evolution of media reporting, not least because the latter war was waged in the name of counter-terrorism. The research for the thesis is foreground in extensive scholarly work, using a hybrid of academic and journalistic research. I have borrowed from the works of several academics, as well as journalists.
\end{abstract}




\section{Chapter 1: Introduction}

"If there were no coverage [...] there'd be no war. Yes, the newsmen and the media men around the world are actually the fighters, not the soldiers any more." - Marshall McLuhan ${ }^{1}$

"If you tell a lie big enough and keep repeating it, people will eventually come to believe it. The lie can be maintained only for such time as the State can shield the people from the political, economic and/or military consequences of the lie. It thus becomes vitally important for the State to use all of its powers to repress dissent, for the truth is the mortal enemy of the lie, and thus by extension, the truth is the greatest enemy of the State."- Paul Joseph Goebbels ${ }^{2}$

Mainstream Western media coverage of the Middle East has evolved vastly over the more than 30 years that I have been a reporter - gradually in the first couple of decades, but more dramatically since $9 / 11$, when Cold War ideology was all but replaced by that of "war on terror." Nowhere has this transformation been as marked as in the coverage of Middle East conflicts. In 1982, following Israel`s invasion of Lebanon, reporters could walk into Palestinian refugee camps in Beirut in the aftermath of a massacre and talk to survivors, do their own investigation, and write very much what they saw and heard. The story overwhelmingly reflected what had happened. Nowadays, when reporters come back from a story, they are not always expected to write what they saw and heard, but are often told by editors: "Here's what we need from you..."

This thesis investigates how Western mainstream media coverage, with a focus on The Associated Press news agency, changed over more than two decades by studying and comparing the reporting of two Israeli wars on Lebanon: in 1982 and 
2006. The two wars represent a microcosm of coverage of the conflicts between the same two countries decades apart. Israel's effective public relations campaign to regain its reputation in the international mainstream media following its 1982 invasion of Lebanon and the massacre of Palestinian refugees there, coupled with America's post-9/11 "war on terror" narrative are at the center of the evolution of coverage of conflicts in the Middle East during the period under study. "Since 9/11, Israel's PR strategy has been to frame all Palestinian actions by, violent or not, terrorism. To the extent that they can do that, they've repackaged an illegal military occupation as part of America's war on terrorism," says Robert Jensen, a journalism professor at the University of Texas in Austin. ${ }^{3}$

The evolution in coverage of the two wars is explored in detail; its effects are examined throughout the following chapters with academic evidence as well as journalistic examples almost entirely through the coverage of the AP, one of the world's largest international news organizations that employs 2,500 journalists in more than 100 countries. The media around the world depend on the AP (as on other wire services such as Reuters and Agence France Presse) for news, allowing the news agency a vital role in framing the narrative and what it considers worthy or unworthy news.

This thesis demonstrates that during the 1982 Israeli invasion, the AP relied mostly on field reporting and facts on the ground. Reporters' knowledge of the area history and geopolitics - allowed them to exercise a fair amount of skepticism in their work, and they were willing to risk their lives in order to get their teeth into the story. 
In contrast, the coverage in 2006 unambiguously leaned toward the Israeli side that claimed it was fighting a "terrorist" organization - Hezbollah. Israel's military and official position was the main narrative, sometime even not giving enough space or credence to its own journalists whose reports may have challenged that narrative, leaving some reporters to wonder if it was worth risking their lives. Human interest stories that reflected the plight of Lebanese civilians or Hezbollah's gains on the battlefield rarely found the space or prominence in AP copy. This was the case even as the AP boasted of its strict rule: the requirement of two sources for a specific news. A story based on one source would rarely be approved, AP contends, and pickups from other media outlets must be confirmed by an AP source. ${ }^{4}$

\section{Methodology}

The research for the thesis is foreground in extensive scholarly work - using a hybrid of academic and journalistic research. I have borrowed from, among others, the works of academics such as Noam Chomsky, Simon Cottle, Herbert J. Gas, David Gilmour, Daniel Hallin, Edward Herman, Karim H. Karim, Jean Said Makdisi, Robert W. McChesney, Angus Richard Norton, Greg Philo, Daniel Pipes, Jay Rosen, Edward Said, Michael Schudson, and Stephen Ward; as well as journalists Terry A. Anderson, Robert Fisk, Tom Friedman, Phillip Knightly, Tim Llewellyn, John Pilger, Eric Rouleau, Ze'ev Schiff and Ehud Ya'ari, a substantial number of stories by AP correspondents, and many more. The significant segment of the academic literature permits the visualization and analysis of media coverage - not only their strengths, but 
also their failures. I provide a set of stories that show a pattern that could explain some of the evolution in the coverage.

In addition, more than 25 former and current AP journalists, including senior editors and heads of departments, are interviewed - by email, telephone, Skype and in person - contributing to the understanding of the changes. I chose to interviewee this selection of interviewees because they were either based as reporters or editors in the Middle East, or were editors or senior editors on the international desk in New York that handled Middle East copy. Four declined to be interviewed; one who agreed, did not respond to my emailed questions. At least four were interviewed more than once. The AP staffers include locals, Americans and non-Americans. Twenty of them spoke on the record, four asked not to be identified; three of those who spoke on the record, asked not to be identified when commenting on certain sensitive issues. To maintain confidentiality, I have respected their wishes and identified all those who spoke anonymously as Interviewees A, B, C, etc. Also included, are "accountability" interviews, responding to criticisms of certain AP reporting. Because of lack of time and in certain cases opportunity, the interviews do not include AP managers. Most of the senior editors and correspondents preferred not to identify the editors who they claimed put pressure on them to make changes or omit certain information or context; it was not clear whether they included senior people in the management hierarchy. Some of these issues will be addressed in the chapters. The questions that are cited in Appendix $\mathrm{F}$ were used as a general guide for the interviews. 
Appendix A provides names and positions of the Interviewees and dates of interviews, as well as a list of those who spoke anonymously, followed by Appendix B that gives a detailed look at how wire services in international bureaus, in this case the AP, have operated over the past three decades, shedding light on technical and technological changes and on the process of the evolution of reporting, writing and editing of stories, and how stories and narratives are formulated before the story is published. Appendices C and D reproduce a 1980 exchange of letters between two senior editors in the Beirut and Tel Aviv bureaus on the coverage of a controversial incident in south Lebanon. The exchange highlights how news was conceived, details the reporting and writing process, selection of sources, and the powerful role of gatekeepers. It also highlights, if not necessarily ideological influences, political factors at play.

AP electronic archives only go back to 1985 , making researching stories difficult. Even stories after 1985 are difficult to access because of the nature of the frequency of updates and two different cycles per day. ${ }^{5} \mathrm{~A}$ list of the AP stories used in the thesis and a reference list is provided at the end of the thesis. One hundred stories have been cited in the endnotes, some with links accessed through Google search, others found in AP archives, and a few via LexisNexis. The stories are examined to establish a pattern on how AP covered the two wars, looking for: presence or absence of context $t^{6}$ (or selective context and where it is found in the story), presence or absence of historical background, source selection (prominence of government/ military sources, including military communiqués; presence or absence of competing positions, alternative voices and views); timelines and sequence of events leading to 
the actual events of the story in question; presence of value-laden language or labels (whether subtle, inflammatory, misleading or inaccurate), "balance," whether vital information is low in the story rather than high up; Absence of vital information. No doubt a simple search of the Google could produce stories that meet some or even all the above criteria, but my aim is to look for a pattern of routine coverage, including boilerplates, ${ }^{7}$ such as "Hezbollah, which the United States considers a terrorist organization," or Israel set up the security zone to prevent cross-border attack." These will be explored in detail in Chapter Three.

Missing context and missing vital information is not uncommon in mainstream reporting from the Middle East - where the pattern can become that of partiality and where the timeline changes according to the narrative, and not facts. In looking at timelines, for example, I survey how the language of "retaliation" has generally been used in stories. Mainstream media timelines usually stress, whatever the facts, that Israel is responding to attacks, in the case of this study, by the PLO in the 1980s or Hezbollah in more recent years. Both sides of the conflict routinely present their attacks as being retaliation for previous attacks or actions and portray them as essentially defensive. According to the media watchdog, Fairness \& Accuracy in Reporting, "whether one regards these justifications as credible explanations or self-serving rhetoric, the fact is that reporters make choices about whether to report them." ${ }^{8}$ The fact that the AP, for instance, generally characterizes Israeli violence as "retaliation" far more often than those of Palestinians or Hezbollah, suggests value judgment on the part of journalists, laying responsibility for the cycle 
of violence on the group being"retaliated" against, since they presumably initiated the conflict, and by doing so, oversimplifying the complicated conflict and doing a disservice to their audience. There is a great deal of history to be covered and explain when discussing these conflicts and the question arises how far back one needs to go in the timeline. The answer is, it depends on the event: sometime you need to go back decades and sometime perhaps just a few days. When reporting the 1982 invasion of Lebanon, the lead of a story that claims Israelis action is to stop PLO rocket attacks on northern Israel, is in fact factually wrong. As we shall find out in Chapter Two, the PLO had not violated a nearly year-old ceasefire once. If the news organization chooses to quote the Israeli army that it is for this reason for its attack, then it has a responsibility to add a line - even in the lead of a story - that the Israeli assertion is inaccurate. In this case you go as far back as the ceasefire came into effect 11 months earlier. It is also noteworthy that none of the stories researched reported Israel itself had in fact in the previous nine months of the June 1982 invasion made 2,125 violations of Lebanese airspace and 652 violations of Lebanese territorial waters. ${ }^{9}$

The importance of timelines will be explored in detail in coming chapters as they shed light on their impact on providing the audience with a clear view of how history is shaped and how events do not come in a vacuum. In the last Chapter we see the impact of these blurred timelines on the audience as a study by a Glasgow University found. ${ }^{10}$

Also cited in the appendix, are: copies that I kept of an "AP Log" (an internal AP bulletin), a few internal AP memos in the form of emails or private AP messages 
that are exchanged between AP staffers only, and personal notes of my interviews and reporting. While this is not a personal journalistic memoir, a substantial portion of the thesis is drawn from my own journalistic experience and reporting for the AP, allowing me to be a prime "source" for parts of the study. In these cases, I use my experience to support or refute some of the academic theories under study as well as with evidence from the memos, emails, private messages and even telephone conversations.

I joined the AP in September 1980, two days before the Iran-Iraq war erupted. The AP, like all other American news organizations, had been expelled from Iran in the wake of the seizure of U.S. Embassy staff on Nov. 4, 1979. Iranian leaders perceived American reporters as linked to the U.S. government. With no access to first-hand reporting from Iran, the AP had relied on reports by the official Pars news agency (later renamed the Islamic Republic News Agency) and the BBC's monitoring service of state-run Tehran radio. The reports, which only reflected government line, were handled by AP's London bureau. Any independent news out of Tehran would have been valuable for the AP, which was in competition with the British Reuters and the Agence France Press news agencies, which still had offices in Tehran. The Beirut office, headquarters of AP's Middle East operation, took over the coverage of Iran from London and I, the only Persian speaker who worked for an international medium outside Iran at the time, became the sole source of independent news of the most important story of the time. Despite the stories I produced for the AP - including numerous scoops - I refrained from using my byline for fear of repercussions against 
my family, who still lived in Iran. For almost a year, I was an anonymous reporter covering Iran from Lebanon. I was also naïve, with no ambition for fame and content with getting the stories. In June 1981, more than nine months after I started working for the AP, Farouk Nassar, who was writing the breaking news of Iranian President Abolhassan Bani-Sadr's impeachment as I fed him the information I was receiving on the telephone from the Iranian parliament in Tehran, insisted that I let him use my byline because the AP was beating every news organization, including those based in Tehran.

The coverage of Iran was by no means limited to the war. My stories on human rights abuses, including the imprisonment, torture and execution of Iranian children, which received huge publicity around the world, drew the ire of Iranian authorities. The Iranian Foreign Ministry and the national news agency in official statements denounced my coverage, referring to me as a "counter-revolutionary," a charge that carried the death sentence. Fortunately, I was not in Iran to face such a punishment, but I had known all along the high price I was paying to report objectively. To continue my work meant jeopardizing any chance of going back to Iran. ${ }^{11}$ The AP appreciated the severity of the situation, and Middle East bureau chief Nicolas B. Tatro was most supportive.

When on June 6, 1982 Israel invaded Lebanon, I switched to daily war reporting, traveling around the country and coming face to face with a different kind of personal risk. I learned journalism in the field, not in the classroom. The war ended in August that year with the departure of the Palestine Liberation Organization along 
with its leader, Yasser Arafat. No sooner had the PLO left Lebanon than more than 1,500 Palestinian civilians were massacred by Israeli-backed Lebanese Christian militiamen in the Sabra and Shatilla refugee camps. Over the next years, I covered every major story in Lebanon, including the April 1983 and 1984 bombings of the U.S. Embassy and the Marine barracks, the continued Israeli occupation of southern Lebanon, the kidnapping of Western hostages, including AP bureau chief Terry A. Anderson. Coverage of all the above events is examined in the thesis.

As a journalist for a major news organization, I had the good fortune of traveling to many major conflict zones to report first-hand and learning in-depth the ins and outs of journalism. I returned to Canada at the end of 2000 and did not resume field reporting until early in 2003 just before the outbreak of the Iraq war. I noticed a striking change that had occurred in just two years of absence. ${ }^{12}$ A new generation of reporters fresh from journalism schools and perhaps suffering from the trauma of 9/11 were now reporting from Afghanistan and Iraq. A climate of "political correctness" that encouraged uncritical patriotic reporting reigned, affecting even colleagues of my own generation who started reporting through the same distorted lens.

The thesis will shed light on the changes, and its focus on the AP in no way attempts to single out the agency as the prime culprit. The AP has some of the most professional reporters with the strictest journalistic ethics. The changes that have occurred over the past years have affected all mainstream media, not just the AP. Just as Karim H. Karim maintains in his book, The Islamic Peril, ${ }^{13}$ my thesis does not advance 
the argument that there is a centrally-organized journalistic conspiracy against Islam or the Middle East, because, "the mechanics of the mass media in liberal political systems do not favor such overt orchestration." 14 The thesis focuses on the AP for three reasons: In addition to my familiarity with the organization and its inner workings, it would have been impossible to examine the coverage of all the major mainstream media for such a study; and since most academic studies have focused on major newspapers or networks, and very few, if any, on a major news agency, it makes it a more worthy and unique study. It is hoped that the project would be valuable for those interested in media studies and the Middle East.

While the huge technological changes over the decades have facilitated news gathering, they have also made field journalism seem less necessary as journalists rely increasingly on live TV coverage on 24-hour news channels for color and description of developing news instead of going out into the field. In 1982, a large team of AP journalists and stringers was spread around the various battlefronts to bring news to the world, even to the local media. In 2006, only two full-time reporters covered the war from Lebanon at a given time and not necessarily the fighting itself. The agency relied mostly on Israeli military and government communiqués for the progress on the war; to give "balance" to the reports, it cited a few Hezbollah statements. Statements from Lebanese officials were used to give casualties numbers, which were often overshadowed by the lower figures provided by the Israeli government. Reporters in the field mostly 
wrote features; analyses were often written in Cairo, thousands of miles away from the action.

The Middle East, consisting of an area that spans southwestern and western Asia and North Africa, is one of the most militarized regions of the world - and parts of it enjoy enormous oil wealth, thus it receives a great deal of international media attention not always veering toward facts. Coverage is largely from the perspective of each country's relationship with the West, particularly the United States, and since the U.S. is involved both directly and indirectly in almost every country of the region, the coverage is so politicized - and often partial - that, as many academics and media experts have noted, some of the basic and classical journalistic "rules" are often compromised. The coverage is generally characterized by what Edward Said referred to as a "highly exaggerated stereotyping and belligerent hostility"15 - a racial and religious misrepresentation that is no longer practiced with such impunity in today's "politically correct" culture. "So inflamed against Islam has the media environment in the United States and the West generally become. ... [that] malicious generalizations about Islam have become the last acceptable form of denigration of foreign culture in the West; what is said about the Muslim mind, or character, or religion, or culture as a whole cannot now be said in mainstream discussion about Africans, Jews, other Orientals, or Asians." 16

At the same time, little attention is paid to providing context or background in reporting this complex and ancient part of the world. It is, therefore, largely dogged 
by what academics such as Said and Noam Chomsky would generally regard as superficial reporting, resulting in the presentation of misleading information and discrepancies in the details of particular events or conflicts, specifically regarding their links to the West.

According to Herman and Chomsky, by relying on experts and authority figures, the media construct a narrative and establish it as the only true and genuine story; other dissenting views would then contradict popular beliefs and feelings which further solidifies the monopolizing narrative. ${ }^{17}$ To this effect, this thesis provides examples of value-laden language, labels, selective sources and timelines that sometime lead to distortion, spin, and confusion. A study by Glasgow University, that highlights this confusion, found many respondents believed it was the Palestinians who were occupying there Israeli-occupied territories and not the Israelis. ${ }^{18}$ Robert W. McChesney notes context may appear periodically, but is rarely followed up with little impact. These theories will be explored in detail.

In both wars that I covered, Israel used a vast arsenal of U.S.-supplied hightech weapons against guerrillas armed mostly with crude rockets. In 1982, the Palestine Liberation Organization's military capability was no match for Israel's superior army, which claimed its aim was to end PLO rocket fire against its north. But its occupation of Lebanon lasted 18 years (which led to the creation of Hezbollah as a resistance guerrilla group) and tarnished its reputation worldwide and its military at home. In addition to killing tens of thousands of civilians and laying siege to West Beirut for two months and destroying much of its infrastructure, Israel also allowed 
its Lebanese allies of the Christian Phalange militias to enter the Sabra and Shatilla Palestinian refugee camps in Beirut and massacre more than 1,500 civilians as the Israeli army watched. If the 1968 Tet offensive by the Vietcong proved a key moment in the U.S. war in Vietnam and changed the tide of public support, the Sabra and Shatilla massacre, the bloodiest single incident in the Arab-Israeli conflict until then, marked a turning point in Israeli public support for the war. ${ }^{19}$ The incident also proved to be a key factor in the drastic change in coverage of the Arab-Israeli conflicts in mainstream U.S. media in the years to come. Following the backlash, Israel launched an aggressive public relations campaign to improve its tarnished image. The Hasbara Project ${ }^{20}$ that targeted Western media, included "sustained cultivation of interpersonal relationships with media professionals and influential newsmakers, the early dissemination of news capsule press releases to foreign bureau offices in order to have an on-hand, convenient, ready-made response and included viewpoint in the accounting of the day's significant events, and even the publication of prescribed vernacular and reporting guidelines that not only sanitize the tone, but more importantly, help to implicitly shape the lexicon - and, consequently, the underlying sympathetic attachment - of news articles." ${ }^{21}$ The project that has become an extraordinary propaganda machine today will show up throughout the thesis and will be explored as it becomes more aggressive over the years.

Reporting on the Israeli-Arab conflicts has proven to be one of the most challenging for journalists, especially in post-1982 invasion of Lebanon and even more so in post-9/11. These conflicts that recur periodically are the most scrutinized 
by Israel's propaganda machine that, according to media critics, goes as far as "harassing" journalists and their editors in order to make sure the coverage is predominantly pro-Israel. ${ }^{22}$ The American Israeli Public Affairs Committee (AIPAC) is the most influential U.S. organization to reiterate the official Israeli line and organize grassroots opposition to unfavorable coverage. A host of media watchdog groups monitor and pressure journalists and their editors to make sure coverage is pro-Israel. The most prominent is the Committee for Accuracy in Middle East Reporting in America, or CAMERA, ${ }^{23}$ an American pro-Israeli media-monitoring organization. Another, apisraelwatch.com, ${ }^{24}$ reserves its scrutiny for AP stories. "AP claims to have more than half the world's population as readers and viewers," says an August 20, 2010 entry on its Website. "It influences public opinion and government policy internationally, as no one else. However, AP can write whatever it wants. Sure, freedom of the press is the best safeguard of democracy; democracy the best protector of human rights. But on the other hand, no one insures that what AP writes is truthful and fair, but... our feedback. There is a need to put this in check." ${ }^{25}$ It says it singles out the AP "because we like AP and we want it to abide by its standards also about Israel." Also "because we want AP to set the standard for all other firms. ... Because AP is the biggest and after that reports fairly and honestly about Israel, all the others will have to follow. ... because this action is about helping the best to improve, not about killing the worst." The site also acknowledges when the AP satisfies their standards. "You'll find the good AP reports reviewed in Chapter 2, the poor ones in Chapter 3, all of them below or in Chapter 0, and the most important ones in Chapter 
5." It offers recommendations on how to make AP coverage favorable to Israel.

When, for example, the “AP misses the mark: We don't whine - rather, we accuse.” It urges its followers to investigate "who trained AP's senior editors and who pays them," and then fine them for "slander" so that the organization "won't pay to be a hate monger or bigot anymore." It also urges its readers to write emails to the AP with their complaints. ${ }^{26}$

Another site that scrutinizes AP's Israel coverage is Yourish.com. ${ }^{27}$ The Israel Project's 2009 Global Language Dictionary ${ }^{28}$ a manual that provides Israeli supporters with "many specific words and phrases to help you communicate effectively in support of Israel," is a reference for spreading the Israeli propaganda. AP's former Israel bureau chief Steven Gutkin acknowledges that the Israel story is the globe's most scrutinized story.

The story of Israel is that of a nation rising from the ashes of the worst genocide in human history, being attacked from all sides upon its inception. Depending on your point of view, it's also a story about the persecuted becoming the persecutors. All of this, of course, is happening to the people of the Bible, the descendants of the Hebrew slaves who were led out of Egypt by Moses and from whose ranks emerged Jesus Christ. It's as if a new chapter of the Bible is being written in our times. Whether you think the Bible is mythology or the word of God is beside the point. The point is we are all human beings who love a good story, and this one is particularly good." 29

Gutkin says the Jerusalem bureau tried to take the challenge in stride. "As long as we angered each side equally, we surmised, we were doing something right." ${ }^{\prime 30}$

As bureau chief, I knew it was one of my key roles to fight bias in our reporting. Was this achieved all the time? I doubt it. But I know an honest attempt was made at all times. I always told our reporters not to deliver 
"milk toast" and to lay bare the raw passions of each side in all their glory, rather than trying to tone down the arguments. While fairness was of utmost importance, I told them, not every story had to be 50-50 (if you were reporting in 1930s Germany, I asked, would you be compelled to give half the space to the Jewish side and the other half to the Nazis?) ... There's no such thing as perfect balance and a complete lack of bias. Not when you're dealing with human beings. But there is something called good faith, and I'm proud to say we had lots of it in Israel and Palestine. I say that in the spirit of fighting bias - not as a Jew, but as a journalist.

We shall explore in Chapter 5 how the AP Jerusalem covered the 2006 war.

Reporting on Middle East conflicts prior to 1982 was not free of bias either or without ready-made narratives. During the Cold War, enemies of Israel were identified by their ideological ties to the former Soviet Union: Syrian arms and fighter planes were almost always referred to as Soviet-made, but rarely were Israeli weapons or government described as U.S.-made or U.S.-backed or financed. ${ }^{31}$ Arab countries that were U.S. allies were (and still are) described as moderate while American adversaries were called hardline, or even rogue, states.

The newer generation of journalists who neither experienced pre-1982 nor pre-9/11 Middle East journalism, have largely been trained to report on the Middle East from the prism of the "war on terror" and are often equipped with ready-made narratives and preconceptions they may not even be aware of. In post-9/11 reporting on the Middle East, says former CIA officer Philip Giraldi, "control of the preferred narrative accelerated and became even more essential in the instant-news political culture as the government and corporate mainstream media worked together to label, identify and attack a series of enemies as a response to what has been shaped as a global terrorist 
threat. The best known attempt to shift the blame and thereby redirect the narrative was President George W. Bush's famous assertion that 'those evildoers' of 9/11 'hate us because of our freedom.' Other, more plausible motives need not apply." 32

Media critics hoped the attacks on New York and the Pentagon in Washington would provide an opportunity for the media to "redeem" themselves. At the same time, they praised the same media for rising to the challenge when the first airplane crashed into the World Trade Center. American sociologist Michael Schudson wrote of the media's extraordinary job and specifically New York Times' coverage, as "little short of miraculous" in reporting "intensely, humanly, and in large measure fairly." $33 \mathrm{He}$ acknowledged - but without criticism - that the coverage lacked context and did not ask the necessary questions. In what appeared as justification, he cited syndicated columnist Ellen Goodman, who wrote on December 7, 2001: “There was only one side. No editor demanded a quote from someone saying why it was fine to fly airplanes into buildings. No one expected reporters to take an 'objective' view of the terrorists." 34 Goodman, said Schudson, was ready to embrace the mantra of Fox news director Roger Ailes: "be accurate, be fair, be American."

But what exactly is accuracy and fairness - or even American? Schudson did not seem concerned that journalism's real test comes during times of crises. To be accurate and fair is not only to report the events as precisely as they take shape or how people react to them, or suffer because of them, but to put the events into context, to tell readers and viewers why it happened - and the history of American foreign policy in the Middle East, going as far back as the 1980s, when the U.S. trained and financed Afghan and Arab 
fighters to fight the Soviet occupation of Afghanistan. Generally, some of the same journalists who failed this test were the ones who had belittled journalists from police states for publicly expressing similar sentiments toward their ruling tyrants, or failing to grill their officials. This trend set a disturbing journalistic precedence for what was to come. Thirteen years on, we can explore the effects more clearly. A new generation of aspiring reporters was the first to be influenced by this post-9/11 journalism "ethics." At the height of the wars and occupations, the major news organizations had two or three reporters at a time on the ground, plus photographers, yet news was at best superficial when it came to understanding the countries and the region at large. The role of the military was rarely questioned. Most of the journalists went to cover Iraq for example had never been to the Middle East and had no knowledge of the region, its politics, religion or culture. ${ }^{35}$ For fear of pressures - either real or imagined - journalists mostly avoided asking officials and military personnel tough questions about their actions against innocent civilian Iraqis. Later in the war, stories that demonized and dehumanized Muslims or Arabs, on the other hand, flourished. ${ }^{36}$

For years, AP foreign editor Nate Polowetzky's motto was: “cover the fall of the sparrow," that is the full flow of details making a story. Foreign stories were moved on U.S. wires with the idea that some newspaper in America with audiences unfamiliar with the world would print each story. The most important AP rule, says former AP Middle East news editor GG Labelle (Appendix A, 13), was the need for objectivity - to "cover a story down the middle, not giving too much credence to one side or another in any conflict." The down the middle rule is what Daniel C. Hallin ${ }^{37}$ 
calls the "sphere of legitimate controversy" where "objectivity and balance reign as the supreme journalistic virtues." 38 It implies, Labelle notes, covering the story dispassionately, not getting caught up in the emotions of a situation. However, many journalists, including some working for the AP, regarded "objectivity" as an impossible goal and believed "fairness" was a better target. In either case, however, there was a tendency to put the point of view of both sides of a conflict into the story. "This sometime added up to wishy-washy coverage. It also meant downgrading what a reporter had witnessed by setting it against comment by some spokesman or other who was not even on the scene," says Labelle. According to Edward S. Herman and Noam Chomsky's propaganda model ${ }^{39}$ such a notion of objectivity in practice ends up heavily favoring the viewpoint of government and powerful corporations.

Since the middle of the nineteen century when science and empiricism replaced religion to explain the world, there have been endless debates and discussions about what constitutes objective journalism, or whether it is at all possible. By the turn of the twentieth century, according to media historian David Mindich, the flaws of objective journalism began to surface. ${ }^{40}$ Scholars have widely accepted that the traditional definition of objectivity in the modern practice of journalism is an ideal that cannot be reached. Journalistic standard of objectivity has traditionally been defined by six components: factuality, fairness, non-bias, independence, non-interpretation, and neutrality/detachment. ${ }^{41}$ Straying from any of those components was considered flawed journalism. Nevertheless, "traditional" journalism that relies on expert sources, reporting "facts," and aiming for balance is 
open to debate, says Hallin, and objectivity continues to be considered a "mask behind which journalists conceal their aptitude for distortions, de-contextualization and mere laziness." 42 To avoid being accused of political bias, he argues, "journalists adopted the concept of objective journalism whereby: the journalist's basic task is to 'present facts,' to tell what happened, not to pass judgment on it." ${ }^{\text {"43 }}$ Sociology professor Gaye Tuchman takes a similar view, arguing that objectivity is used as an ethic to protect journalists from criticisms of illegitimacy: by quoting people, for example, or verifying facts to ensure accuracy, and the inclusion of doubt when facts cannot be confirmed. ${ }^{44}$ Schudson extends Tuchman's approach by arguing that objectivity is not only an ethic, or a ritual, but an ideology for journalists and their audience. ${ }^{45}$ In his 1978 book, Discovering the News, he wrote:

From the beginning ... criticism of the 'myth' of objectivity has accompanied its enunciation. Objectivity in journalism seems to have been destined to be as much a scapegoat as a belief and more an awkward defense than a forthright affirmation.... . Journalists came to believe in objectivity, to the extent that they did, because they wanted to, needed to, were forced by ordinary human aspiration to seek escape from their own deep convictions of doubt and drift. $^{46}$

Some academics have chosen to steer away from the notion altogether. In his book, Islamic Peril, Karim H. Karim argues that objectivity is "a human impossibility"47 - accuracy is more in the realm of mathematics than journalism; balance, of which fairness is a component, is "reduced to ritually supplying just two points of view that may not be essentially different." He prefers the term "conscientious" or "informed" journalism that requires "going beyond the dominant cognitive scripts and models that 
govern traditional reporting of the subject matter, avoiding the use of generalizations and stereotypes, and seeking diverse viewpoints on 'positive' and 'negative' aspects of the story." $48 \mathrm{He}$ adds: "Bad journalism is replete with speculation, false dichotomies, and absolutes (e.g., clichés such as 'the gulf between Islam and the West can never be bridged')." While there have been some attempts "to understand Muslims better, the older discourses on Islam continue largely to provide the frameworks for their portrayal." ${ }^{49}$ These frameworks will be explored in the following chapters.

In his influential study of U.S. media during the war on Vietnam, Daniel Hallin argued that journalism's commitment to objectivity has always been compartmentalized. He devised a paradigm to explain the shifting patterns of how journalists cover a war and decide which news should be covered and which ones ignored. In the sphere of consensus, journalists "do not feel compelled to present opposing views or to remain disinterested observers. ${ }^{\circ 0}$ In their coverage of Vietnam, he said, journalists went as far as reporting lies that they were aware the establishment was telling them and omitting significant facts that would have shed light on the nature of the war. There was, according to Hallin, a consensus on Cold War ideology that identified Communism as a threat to American national security, so reporters - many of whom shared the ideology - did not discuss or question it. The Johnson administration was able to exploit this sense of "patriotism" to its advantage without the need to impose censorship on the media, which for their part and to the delight of the government, seemed more than willing to resort to self-censorship. ${ }^{51}$ In the sphere of legitimate controversy, "objectivity and balance reign as the supreme journalistic virtues." ${ }^{52}$ Here, journalists seek conscientiously to be 
balanced and objective, and feel free to invoke a generalized "we" and to take for granted shared values and shared assumptions. ${ }^{53}$ When President Kennedy was assassinated, said Hallin, no journalist felt obliged to seek out sources to praise the assassin as well as to condemn him. The assassination was treated as a national tragedy and the media audience addressed as part of a large national family that had suffered a grievous blow - similar to the coverage of 9/11 nearly four decades later. The sphere of deviance is where the journalist "plays the role of exposing, condemning, or excluding from the public agenda those who violate or challenge the political consensus," and, therefore, are unworthy of being heard or read. ${ }^{54}$ Journalists also depart from standard norms of objective reporting and feel authorized to treat as marginal, laughable, dangerous, or ridiculous individuals and groups who fall far outside a range of variation taken as legitimate.

In his book, Deciding What's News, sociologist Herbert Gans argued that while “journalists attempt complete impartiality, especially by eschewing 'extremist' ideology," implicit values are inextricable from the news - even in terms of selecting stories, accessing sources, and asking certain questions.

The values in the news are rarely explicit and must be found between the lines - in what actors and activities are reported or ignored, and in how they are described. If a news story deals with activities which are generally considered undesirable and whose descriptions contain negative connotations, then the story implicitly expresses a value about what is desirable. In the process, the news also assumes a consensus about values that may not exist, for it reminds the audience of values that are being violated and assumes that the audience shares these values. Because journalists do not, in most instances, deliberately insert values into the news, these values must be inferred. Since inference cannot take place without an enferrer, however, and different people come to the news with different perceptions, they may infer many different values from what they see or read. Also, the analyst's own values make him or her more sensitive 
to some values in the news than to others; as a result, content analysis is often a comparison of the analyst's values with those that 'exist' in the content. ${ }^{55}$

Gans' theory will be explored further in Chapter Three with examples of AP's use of value-laden language and labels, and journalists' opinion of them. Unlike reporting on domestic news, American media generally treat foreign news with less detachment, particularly those considered rivals or hostile to the U.S. Also, journalists insert implicit American values even as they try to be impartial. They often express the dominant political ideology unconsciously. ${ }^{56}$ Islam and the Middle East have now replaced the ideological narrative that once framed stories about the former Communist bloc.

News reporting has clearly changed since Gans published his book in 1979 when national news was limited mostly to what he called "mono-perspectival news, sometimes also called stenographic news," and when news was based on authoritative sources (usually government). In a 2011 article, Gans introduced the concept of "multi perspectival journalism." ${ }^{57}$ Professional journalists have not changed, wrote Gans, nor has there been a big change in news judgments - even the "inverted pyramid" is still in place. The change, he said, has occurred in the newsrooms. Today, thanks to cable news and the Internet, the news is much more "multiperspectival" than it was in the past, even though it reaches a far smaller news audience than traditional legacy news. ${ }^{58}$

In his book, Gans described news organizations - which in many ways remain the same - as undemocratic, even "militaristic" where the top editors (or TV/radio producers) and their assistants "have power to decide what gets into the print or on the air, at what length, and in what order, subject only to suggestions or vetoes from news and corporate 
management." Since, "every story passes through several hands before it reaches the audience," newsrooms are described as assembly lines. Senior editors, he said, are responsible for "selecting and readying stories in their own sections, with the advice, consent, and final review of their superiors." Each senior editor, in turn, "reports to one of the top editors, who divide the section amongst themselves; but the top editor usually reviews the work for his assistants." The function of the journalists is story production: they assemble the information that goes into a story and write or film it. The final shape of the story is often a compromise. Policy, said Gans, is made by corporate and news executives who "sit" outside the news organization. Top editors and producers consult with executives about "touchy" stories which might generate audience or government protest. "Communication with top editors must normally go through channels, although they are concurrently expected to maintain an 'open-door policy,"” wrote Gans. "Like all organizations with branches, news organizations experience endemic conflict of interest between New York and the bureaus, which often feel that their stories are not considered important enough in New York." Lastly, said Gans, "the power of top editors, and of superiors in general, is maintained by organization-wide pressures for conformity." 59 Changes in the newsrooms and technology are discussed in detail in chapters two and five, as well as in Appendix B. Also discussed extensively throughout the thesis, is the point Gans makes - central to this study - the power and pressure from groups or individuals, including sources and audiences, "with power to hurt them, their organizations, and their firms." ${ }^{\prime 0}$ One of the major pressures that impacts coverage of the 
Middle East, as mentioned, is Israel's public relations efforts - examples of which were give above.

Debate about objectivity has also centered on the role of the modern-day journalist: is it someone who merely chronicles events and simplifies complicated issues for a mass audience, as the host of the BBC Radio Ulster William Crawley articulately asked two journalists with opposing views in a March 4, 2012 discussion? ${ }^{61}$ Or is the journalist expected to be a fearless crusader, telling "the right side" of the story? Or are those lines often blurred? Martin Bell, a former BBC correspondent who covered the 1992-1995 war in Bosnia, believes there is nothing new about "campaigning journalism" and cites William Howard Russell of the Times of London during the 1854-1856 Crimean War as an example. Russell, he said, implicitly campaigned in his writings from the front for better medical treatment. His powerful dispatches apparently were instrumental in bringing in more supplies and even bringing down the government in London. ${ }^{62}$ Journalist Brendan O'Neill ${ }^{63}$ on the other hand, accused some journalists of trying "to change the shape of the conflict" they report on, and who could "encourage intervention" - as we have seen in the war on Iraq. He raised the crucial point of context and background history that is often missing in many of the mainstream media's reporting of international news and conflicts that lead to missing the nuance and historical aspects specific to the conflict.

Brent Cunningham, managing editor of Columbia Journalism Review, dares ten journalists to define objectivity and assures us that all ten will give different answers. ${ }^{64}$ According to journalism professor Michael Bugeja, "objectivity is seeing the world as it 
is, not how you wish it were.” The Society of Professional Journalists in the U.S. acknowledged this dilemma in 1996 and dropped "objectivity" from its ethics code. It also changed "the truth" to simply "truth." ${ }^{65}$ Journalists' "tortured relationship with objectivity" is the conflicting expectation of having to be neutral yet investigative, disengaged but have an impact, be fair, but have an edge. ${ }^{66}$ One of the reasons why news objectivity has remained a sought-after discipline and why journalists continue to believe in it as a necessary goal, says Cunningham, is because nothing has replaced it, one that is less restrictive and more grounded in reality. "Objectivity helps us make decisions quickly - we are disinterested observers after all - and it protects us from the consequences of what we write. We'd like to think it buoys our embattled credibility. But our pursuit of objectivity can trip us up on the way to 'truth.' Objectivity excuses lazy reporting. If you're on deadline and all you have is 'both sides of the story,' that's often good enough," says Cunningham. In pursuit of objectivity, he says, "we fail to push the story, incrementally, toward a deeper understanding of what is true and what is false." $\mathrm{He}$ quotes Steven R. Weisman, the chief diplomatic correspondent for the New York Times, who felt obliged to dig more when he became an editorial writer. "If you have to decide who is right, then you must do more reporting," Cunningham quotes Weisman as saying. "Relying on official sources is the easiest, quickest way to get both the 'he said' and the 'she said"' and, thus, 'balance.'

Among media scholars who have offered alternatives to traditional definitions - or requirements - of objectivity, is Stephen Ward, professor of Journalism Ethics at the University of Wisconsin-Madison, who believes objectivity depends on the place or time 
it is employed. He puts forward the concept of "pragmatic objectivity" - that he acknowledges is not perfect. ${ }^{67}$

Pragmatic objectivity begins with the premise that everything we know is an interpretation of some aspect of our world. All beliefs, descriptions, theories and points of view contain some element of conceptualization, theorizing and evaluation. Even our perceptions of objects do not provide direct contact with reality, but are the result of much filtering of stimuli by our concepts, beliefs and expectations. An interpretation is objective if it is well justified according to the best available standards. ${ }^{68}$

Ward suggests three types of standards: empirical, that "tests a belief's agreement with the facts, such as standards for careful observation, controlled experiments, statistical measurement and prediction;" coherence that "evaluates how consistent an interpretation is with the rest of what we believe, such as standards of valid reasoning;" and rational debate that "includes a commitment to rational persuasion and tolerance, to fair consideration of rival views and counter-evidence" - or balance. He agrees that these standards will in many cases conflict and require "imprecise trade-offs" between them. While he accepts that it is not humanly possible to reach certain knowledge, journalists can "muddle along perfectly well" with certain plausible beliefs and standards. All pragmatic objectivity demands is skepticism about particular claims and standards. "We can avoid a narrow viewpoint by keeping our standards of objectivity open to reform. We can do no better," argues Ward, since "there are no value-free or theory-free reports."

But in order to have a balanced report, is it enough to include all views or only the credible ones? Who decides which ones are credible? "Decisions about relevancy and balance test the journalist's ability to make weighted judgments in a problematic context, 
under pressure of deadlines. There are no easy formulas to help one decide, no absolute principles. Yet reasonable, non-arbitrary judgments must be made about specific norms such as fairness and the overall objectivity of a story," says Ward. But who decides that journalists have met the standards when standards are subjective? Neutrality, a component of pragmatic news objectivity, comes in various forms and degrees, depending on the story, he says. Objective, neutral reporters should approach issues without allowing their passions, interests or preconceptions to bias their reports. We shall explore in Chapter Four whether this is possible. Unlike straight news reports, interpretive and analytical pieces require context and assessment, including historical perspective, says Ward. "Reporters and editors need a clear idea of what objectivity is and why it is valuable - as more and more, reporters use a lively, opinionated style, or adopt an interpretive stance toward stories, when facts are mixed with interpretation and context. This argument is explored in Chapter Five with regard to AP's move toward interspersing analysis and interpretation within hard news.

In assessing Ward's theory of "pragmatic objectivity" as an alternative to the strict concept of "objectivity," Winnipeg University journalism professors Brian Turner and Judith Kearns go even further and argue that "the current economic climate may call for an even greater tolerance of imperfection, and more patience about the unfolding of truth in time." ${ }^{99}$ They question the feasibility of objective journalism, at the heart of which it requires reporters to provide straight, unbiased information by using authoritative and reliable sources and quotations; to provide attribution and be vigilant in the verification of their information; to balance their 
story by providing different points of view; and avoid loaded or emotional language. These criteria, they say, render it difficult for journalists to make proper judgments. Neutral language, they say, can sometime be inappropriate because it can understate the unfairness or the gravity of a situation. The balancing of a report can be misleading, for it could suggest the opposite sides are equally valid. The subtle use of emotive words, mainly adjectives that denote negativity or sympathy are another form of journalistic misconduct. For example, the 9/11 attacks are often referred to as "tragic" in mainstream American media ${ }^{70}$ while the 1982 massacre of more than 1,500 Palestinians in a refugee camp in Lebanon by Christian militias, as far as my research goes, is rarely referred to as tragic. Hezbollah is almost always referred to in the Western media as Iranian-backed ${ }^{71}$ or Iranian-financed, but Israel is almost never described as U.S.-backed. By omitting some references and amplifying others, the media undermine the objectivity that they boast about or often insist they uphold. Neither Turner and Kearns, nor University of Groningen professor Chris Peters address these subtle and overlooked media practices. Turner and Kearns claim that since journalism is "inherently a value-laden craft" and "can never have the rigor of science," fewer and fewer journalists - who "rely on non-systematic hodgepodge of common sense, skepticism, and follow informal rules with varying consistency - are embracing the traditional practice of journalism. The ideals that assume reporting can be free of bias and the reporter "can be a perfect 'recording instrument' for conveying the truth is to deny both the humanity of the journalist and the complexity of her task." ${ }^{72}$ Instead, they suggest imperfection. 
The goal in this 'precarious epistemological situation' ought not to be perfection or the Truth, but the best one can do in the circumstances, the truth as one sees it. For this, the use of facts and expert opinion is necessary, but it is rarely sufficient. What is also needed is interpretation of fact and opinion - in short, 'reasonable judgment in a context.' Traditional objectivity subverts such judgment. ...Imperfectionism reduces expectations but does not settle for the status quo. It recognizes that institutions, perfect forms of reasoning, and imperfect spheres of human activity may still contribute something useful to society... It sees value in seeking the most reasonable beliefs and the best, but imperfect, practices in many areas of life; it values practical reasoning and non-absolute forms of inquiry, even if the conclusions are fallible. ${ }^{73}$

They then give a list of Ward's guidelines that call on journalists to be pragmatic and employ methods of traditional objectivity with the possibility that they may all not be achieved. "Reflective equilibrium," they contend, can resolve the flaws in achieving the "balance" that has dogged traditional objective journalism. ${ }^{74}$

The problem with this argument is that it appears to put the blame entirely on the unfeasibility of achieving objective journalism as human beings, and not on journalists, who the scholars see as genuinely desiring to be honest reporters. They give a great deal of credit to the integrity of the media, including journalists and editors, and ignore the fact that journalists have often neglected to do their job professionally - not because of human nature, but by failing to give context to complex stories and ignoring the bigger picture of a conflict, or selecting ethos as journalist O'Neill mentions: seeing things from the "good-and-evil mindset." Time and budget constraints mainly limit the number of stories and places that can be covered; but those that journalists do cover, including from bureaus and from behind 
desks, also often fail to give the whole picture. It was not time or budget constraints that prevented the AP in November 2012 to report accurately and diligently when it claimed a diagram it had obtained from "officials of a country critical of Iran's atomic program," showed Iranian scientists had run computer simulations for a nuclear weapon that would produce more than triple the explosive force of the World War II bomb that destroyed Hiroshima. ${ }^{75}$ Thanks to bloggers who drew attention to the story that went viral, two respected scientists shot down the "scoop" in an article in the Bulletin of Atomic Scientists, saying the diagram was unlikely to have been made by research scientists and that the image did not "imply that computer simulations were actually run, even if they were, this is the type of project a student could present in a nuclear-science course." 76 The blame in this case lies entirely on AP's misreporting and has nothing to do with difficulties of juggling time constraints, huge news flows and shortage of staff. This kind of journalistic misconduct has been around long before budget cuts and shrinking staff. It could even be argued that "pragmatic objectivity" has been a commonplace in mainstream media, even if not the kind Ward had in mind.

In light of the above review, this is the yardstick I have used to assess objectivity: good journalism requires the discipline of being honest, credible, authentic, and informative. These can be achieved to a great extent with indepth knowledge about a story - the history and context that is required to explain and frame it; by being aware of and challenging any biases that may creep into copy or during reporting, or from sources; by diligently examining opposing views, not just 
citing them - the contrived he-said/she-said balances; by thinking critically, and exercising skepticism. Journalists must not only ask what happened, where and how, but why. In writing stories, they ought to make sure they are not using value-laden language or labels, are not blurring timeline of events, to make sure a story has context with sufficient historical background. This is possible even as an embed reporter with one's own army. Academic Howard Tumber ${ }^{77}$ is right in that the military go to a considerable length to constrain and channel what embed reporters see and produce and that the journalists understand the limitations of their reporting. However his argument that embed journalists can only cover the mechanics of how a modern war is fought is debatable. By relying on the limited sources available, says Tumber, embed reporters have to the difficult task of putting together the jigsaw to produce a complete picture and therefore there is no guarantee of objectivity or providing the truth.

But is it not a good journalism exercise to try to put the jigsaw together? Embed journalists can be neutral and objective and do not necessarily have to be supportive of the military in their writing. They can quiz and grill their military sources and challenge them if they happen to be giving them propaganda. There is no rule that says embed journalists have to be accommodating. It is true that journalists cannot reveal the identity of their sources if they have been so instructed, or write about certain troop movements, but this does not mean that they have to be part of the military team, even if they grow close to some of the troops or care for their wellbeing. They can remain skeptical and vigilant and not allow the military to use them 
as propaganda tool, even if they have no other sources to talk to. Western journalists who embed with a local army - say in Iraq or Afghanistan - are able to keep their professional distance and write skeptically about a foreign army, so why not about their own? There are some Western journalists who do so. Embed journalists have to be upfront in informing the public that their reporting is one-sided and their information cannot be independently verified. They have to clarify how exactly they went about gathering their information and how much of the action was for the benefit of the camera, for example. Even when interviewing civilian Iraqis, for instance, where the military is present, the information and opinion of the interviewees could be distorted: civilians may be afraid to talk honestly; or translators provided by the military do not always give the exact translation - as I witnessed in Iraq.

\section{Endnotes}

\footnotetext{
${ }^{1}$ Marshall McLuhan and David Carson The Book of Probes (NY: Ginko Press, 2003).

2 This quote has been challenged and some claim it does not belong to Goebbels, yet it's widely cited.

3 "Peace, Propaganda \& the Promised Land: U.S. Media \& the Israeli-Palestinian Conflict," 2004, Documentary directed by Bathsheba Ratzkoff, Sut Jhally. http://www.youtube.com/watch?v=eCL6WdnuNp4

4 Tanalee Smith (Appendix A, 27), AP editor in Cairo, New York and Asia. Email Interview. April 26, 2013.
} 
${ }^{5}$ There are three cycles in day at the AP: AM - indicates that morning newspapers have first use of the story; PM - afternoon newspapers have first use of the story; On a fast developing events, stories are updated frequently and at great speed, mainly catering to radio and TV clients and Websites; they can, throughout the day, reach 10th or 20th Ld Writethrus. The designator BC before a slug is for an item used by either AMs or PMs immediately if it is a spot item, or on the publication date if it is an advance. Usually stories are numbered in sequence - e.g. BC-ME-GEN--Lebanon-Fighting ....1st Ld Writethru, or just 2nd Ld, 10th Ld, etc. and/or 1st Add, 2nd Add, etc.

Some stories are fixtures - advances and AP Photo and Graphic Updates, for example, are given predetermined numbers. For instance, the PMs Digest that opens the PMs cycle is always a9000 or p9000 on the high-speed lines. Priority codes are used by the AP to assure that stories are sent in the order of their urgency. At newspapers, the codes can be used by computer systems to determine the order in which stories come to an editor's attention. For example, f - Flash, highest priority, seldom used; $b$ - Bulletins, first adds to bulletins, kill notes; $\mathrm{u}$ - Urgent, high-priority copy, including all corrections. It must be used on all items that carry an urgent slug; $r$ - Regular priority: stories of a routine nature; $d$ - Deferred priority: used on spot copy that can be delayed; a - for weekday advances designed for use more than 12 hours after transmission. (Hold-for-release material sent for use less than 12 hours after transmission carries a spot news priority); $\mathrm{s}$ for Sunday advances designed for use more than 12 hours after transmission; $\mathrm{w}$ - Release at will. Copy that has a publishing value during and after the current transmission cycle. Source: FILING THE WIRE. http:// fredericksburg.com/FreeLanceStarCompany/Newsrooms/newsroom/APStyle/APtxt/Filewire.htm

${ }^{6}$ Context is the circumstances that form a setting for an event, statement or idea and in terms in which it can be fully understood and assessed. It is the set of circumstances, time, place, background, environment within which an event takes place. It determines the conditions and the meaning in which the event is understood. It is a scheme of relations that alters the way we understand things. That set of relations can very broadly and deeply expand out or it can be narrow and pointed making the latter much more easy to grasp and draw definitive conclusions from. If something is taken out of its scheme of relations, the base upon which conclusions can be drawn are shifted. See: Jim Sniechowski, https://www.linkedin.com/today/post/ article/20140120014126-85816712-the-difference-between-context-and-agenda

${ }^{7}$ Boilerplate is phrases or sentences that are a standard way of saying something and are often used (source: Webster dictionary).

8 FAIR, "In U.S. Media, Palestinians Attack, Israel Retaliates," April 4, 2002. http://fair.org/take-action/ action-alerts/in-u-s-media-palestinians-attack-israel-retaliates/

${ }^{9}$ According to Lebanese army figures cited by the New York Times, 1.4 Israeli violations of Lebanese territory were recorded every day from 1968-74, with 17 a day in 1975, when the tally ended. By October 1977, it was estimated that the total number of refugees from the south had reached 300,000. Noam Chomsky,

Fateful Triangle: Israel, the United States, and the Palestinians (Montreal: Black Rose Books Ltd., 1984).

10 Greg Philo and M. Berry, More Bad News from Israel (London: Pluto, 2004).

${ }^{11}$ I was self-exiled until 1995. By then I was working at Toronto's Globe and Mail newspaper and had not reported or written on Iran for more than five years. In Iran, many of the people who had kept a close eye on the international media and journalists had moved on by then and it looked safe to venture back into the

country. This changed in 1998 when I was totally banned by authorities from reporting from Iran.

${ }^{12}$ See for example, Douglas Kellner, International Journal of Communication, "The Media In and After 9/11," 2007. ijoc.org/index.php/ijoc/article/download/197/102

${ }^{13}$ Karim H. Karim, The Islamic Peril: Media and Global Violence (Montreal: Black Rose Books, 2003) p. 4. 
14 ibid.

${ }^{15}$ Edward Said, Covering Islam: How the Media and the Experts Determine How We See the Rest of the World (New York: Knopf Doubleday Publishing Group, 1997) P. xi

16 ibid.

17 Edward S. Herman and Noam Chomsky, Manufacturing Consent: The Political Economy of the Mass Media, (New York: Pantheon, 2002). P. xii

18 Greg Philo and M. Berry, More Bad News from Israel (London: Pluto, 2004)

${ }^{19}$ Linda A. Malone, "The Kahan Report, Ariel Sharon and the SabraShatilla Massacres in Lebanon: Responsibility Under International Law for Massacres of Civilian Populations," William \& Mary Law School. (1985): http://scholarship.law.wm.edu/cgi/viewcontent.cgi?article=1606\& context=facpubs

20 The Israel Project's 2009: GLOBAL LANGUAGE DICTIONARY http://www.webcitation.org/query? url $=\mathrm{http} \% 3 \mathrm{~A} \% 2 \mathrm{~F} \% 2 \mathrm{Fwww}$. newsweek.com $\% 2 \mathrm{Fmedia} \% 2 \mathrm{~F} 70 \% 2 \mathrm{Ftip}$ report.pdf\&date $=2009-08-06$

21 “Peace, Propaganda \& the Promised Land: U.S. Media \& the Israeli-Palestinian Conflict," op cit.

22 ibid.

${ }^{23}$ Documentary, "Peace, Propaganda \& the Promised Land: U.S. Media \& the Israeli-Palestinian Conflict," 2004 -http://www.youtube.com/watch?v=cAN5GjJKAac. Also see: CAMERA. http://www.camera.org/ index.asp? $\mathrm{x}$ context $=2 \& \mathrm{x}$ outlet $=2 \& . .$.

${ }^{24}$ AP Israel Watch. http://apisraelwatch.wordpress.com/

25 ibid.

26 ibid.

27 http://www.yourish.com/2009/09/04/8729

28 The Israel Project' 2009 Global Language Dictionary. http://www.webcitation.org/query?url=http\%3A $\% 2$ F\%2Fwww.newsweek.com $\% 2$ Fmedia $\% 2$ F70\%2Ftip_report.pdf

29 Steven Gutkin, Goa Streets, "My Life As An AP Bureau Chief In Israel," Sept. 5, 2014. http://www.goastreets.com/life-ap-bureau-chief-israel/

30 ibid.

31 GG Labelle (Appendix A, 13): “One reason the reference to U.S.-manufactured arms may be dropped in stories destined for U.S. newspapers is that AP reporters and editors think most American readers already know planes like the F-16 are U.S. products. Or maybe it's just that the reporters or editors themselves know the weapons are U.S.-supplied and it doesn't occur to them to put that in the story." 
32 Philip Giraldi, The American Conservative, "Why We Hate Them: Arabs in Western Eyes" January 2, 2013. http://www.theamericanconservative.com/articles/why-we-hate-them-arabs-in-western-eyes/

${ }^{33}$ Michael Schudson, "What's unusual about covering politics as usual," in Barbie Zelizer and Stuart Allan (ed.), Journalism After September 11 (New York: Rutledge, 2002). P. 37.

34 ibid. p. 39.

35 For instance, a senior journalist, one of AP's star correspondents dispatched to Iraq offered his take on the difference between Sunnis and Shias in Iraq: unlike Sunni women, he said, Shia women wore the long black abaya to cover their bodies head to toe. Unbeknown to him, however, abayas are worn by both Shia and Sunni women.

${ }^{36}$ Kellner, op cit.

${ }^{37}$ Daniel C. Hallin, The "Uncensored War": The Media and Vietnam, (California: University of California Press, 1989).

38 ibid, p. 116.

39 Edward Herman and Noam Chomsky, Manufacturing Consent: The Political Economy of the Mass Media (New York: Pantheon,1988).

40 Brent Cunningham, Columbia Journalism Review, "Re-thinking Objectivity," July 11, 2003. http:// www.cjr.org/feature/rethinking_objectivity.php?page=all

${ }^{41}$ Stephen Ward, The invention of journalism ethics: the path to objectivity and beyond. (Montreal: McGillQueen's University Press, 2004).

42 Hallin, op cit p. 117.

43 ibid.

${ }^{44}$ Gaye Tuchman, The American Journal of Sociology, Objectivity as Strategic Ritual: An Examination of Newsmen's Notions of Objectivity," (Chicago: The University of Chicago Press, 1972) pp. 660-679.

45 ibid, p.152. Also see: Bolette B Blaagaard, Aalborg University Copenhagen, "Shifting boundaries: Objectivity, citizen journalism and tomorrow's journalists," 2013. https://www.academia.edu/7452532 Shifting_boundaries_Objectivity_citizen_journalism_and_tomorrows_journalists_Article

46 Michael Schudson, Discovering the News: A Social History of American Newspapers (New York: Basic Books, 1978) pp. 157-59.

47 Karim H. Karim, Islamic Peril: Media and Global Violence (Montreal: Black Rose Books, 2002) p. 179.

48 ibid.

49 ibid.

50 ibid, pp. 116-117. 
51 ibid.

52 ibid, p. 116.

53 ibid, p. 117.

54 ibid.

55 Herbert J. Gans, Deciding What's News: A Study of CBS Evening News, NBC Nightly News, Newsweek, and Time (Chicago: Northwestern University Press, 1979) pp. 39-69.

56 ibid.

57 Herbert J. Gans, Journalism, "Multiperspectival news revisited: Journalism and representative democracy," January 2011. http://jou.sagepub.com/content/12/1/3.abstract

58 Nikki Usher, Nieman Journalism Lab, "'News media are targeted but audiences are not': Herbert Gans on multiperspectival journalism," MARCH 21, 2011. http://www.niemanlab.org/2011/03/news-media-aretargeted-but-audiences-are-not-herbert-gans-on-multiperspectival-journalism/

5959 Herbert J. Gans, Deciding What's News: A Study of CBS Evening News, NBC Nightly News, Newsweek, and Time (Chicago: Northwestern University Press, 1979) pp. 94-96.

60 ibid p. 80.

61 Brendan O’Neill, BBC Radio Ulster, “Journalism of attachment,” November 23, 2006.

62 ibid.

63 ibid.

64 Brent Cunningham, Columbia Journalism Review, “Re-thinking Objectivity,” July 11, 2004. http:// www.cjr.org/feature/rethinking_objectivity.php?page=all

65ibid.

66 E.J. Dionne, book, They Only Look Dead, (New York: Simon and Schuster, 1996).

67 Stephen Ward, The Invention of Journalism Ethics: The Path to Objectivity and Beyond, April 2006. http://www.mqup.ca/invention-of-journalism-ethics--the-products-9780773528116.php

68 Stephen Ward, Shorentstein Center, "Pragmatic News Objectivity: Objectivity With a Human Face," 1999. http://shorensteincenter.org/wp-content/uploads/2012/03/d37_ward.pdf

69 Brian Turner and Judith Kearns, "Pragmatic Objectivity in Practice: Reading the Globe and Mail columns of Christie Blatchford," Canadian Journal of Communication, 2010. http://connection.ebscohost.com/ c/articles/49802910/pragmatic-objectivity-practice-reading-globe-mail-columns-christie-blatchford 
70 See for example, AP that appeared in ABC Website, "Nation remembers 9/11 -- September 11, 2013, the 12th anniversary of 9/11," Sep 11, 2013. ,http://www.abcactionnews.com/news/national/nation-remembers911-september-11-2013-the-12th-anniversary-of-911

${ }^{71}$ See for example, Zeina Karam, AP appeared on NBC Website, "Iran-backed Hezbollah warns it may intervene in Syria war," May 1, 2013. http://worldnews.nbcnews.com/_news/2013/05/01/17997650-iranbacked-hezbollah-warns-it-may-intervene-in-syria-war?lite

72 Turner and Kearns, op cit.

73 ibid.

74 ibid.

75 George Jahn, AP archives, “AP EXCLUSIVE: GRAPH SUGGESTS IRAN WORKING ON BOMB," Nov. 27, 2012. http://bigstory.ap.org/article/ap-exclusive-graph-suggests-iran-working$\underline{\text { bomb }}$

76 Yousaf Butt and Ferenc Dalnoki-Veress, Bulletin of Atomic Scientists, "DIY graphic design," Nov. 28, 2012

http://thebulletin.org/diy-graphic-design

77 Tumber, Howard and Frank Webster, Journalists under Fire: Information War and Journalistic Practices (New York: Sage Publications, 2006). 


\section{Chapter 2: Summer of '82}

The first wave of warplanes dived through the sky at 3:10, shattering Beirut's already tense afternoon. The first AP dispatch was out within minutes: Israeli jets had bombed "Palestinian strongholds in a swift retaliation for the attempted assassination a day earlier of the Israeli ambassador to Britain."1 A spokesman for the Palestine Liberation Organization (PLO) said "preliminary counts showed at least 30 people were killed and 120 wounded, many of them women and children."2 Dubbed "Operation Peace for Galilee" 3 with the aim of pushing PLO artillery out of range of the northern settlements of Galilee, the Israeli military command in Tel Aviv said "as a result of the criminal attack on the Israeli ambassador and other breaches of the agreement on ceasing hostilities, the Israeli government instructed the Israeli Defense Forces (IDF) to attack terrorist targets in Beirut."4 In the next two days Israel's ground forces advanced up to five kilometers south of Beirut's international airport. ${ }^{5}$ For the first time in the history of media coverage of Arab-Israeli wars, the Western press could operate on both sides of the front line. "There had been some coverage out of Cairo in the previous wars, but not battlefield, or very little of that. But with the '82 Israeli invasion of Lebanon, first of all we had a resident international press corps in Beirut, which turned out to be the destination of the Israelis, so it wasn't like we even had to try to get there - the invasion, the war came to us, or at least those of us who stayed," says Earleen Fisher (Appendix A, 5), a senior correspondent in Lebanon in the early 1980s, in an interview for this thesis. 
Despite a huge international media presence, there have only been a few studies of media coverage of the 1982 war - including Noam Chomsky's ${ }^{6}$ and a report accusing U.S. TV networks of biased reporting against Israel. ${ }^{7}$ The invasion was part of a Cold War conflict that involved several regional and international players - U.S.backed Israel and its Phalange ally; and Soviet-backed PLO and Syria. The invasion would have a ripple effect on the region for years to come. Israel maintained its occupation of most, and later parts of Lebanon for 18 years that saw a bloody armed resistance, resulting in the birth of the nationalist-religious Hezbollah, and Iran's regional ascent. It entangled the U.S. in Lebanese politics and brought it face-to-face with Shia Muslim militants. A series of suicide bombings against U.S. targets in Lebanon diminished American influence in the strategic nation and made the U.S. unwilling to get involved militarily in the region until 9/11. Israel, which became bogged down in Lebanon, lost a significant amount of its credibility, while Iran and Syria gained influence.

As far as my research could verify, there has been no study of AP's coverage of the 1982 invasion and its aftermath. This chapter will show - based on the little literature available - that the major theme that dominated media coverage of the war especially at its outset - was generally the Israeli narrative of self-defense against cross-border shelling of its northern settlements by the Lebanon-based PLO. I will demonstrate AP's operation in the Beirut bureau, where much of the coverage occurred. Interviews with former and current AP journalists who reported on the war provide insight into how the wire service functioned in the early 1980s, including the 
technical and technological aspects of communication; how news was gathered and the factors that influenced selection of stories and sources; writing, editing and gatekeeping at headquarters. AP journalists comment on value-ridden labels and other stereotypes and clichés that have entered mainstream media lexicon that are rarely questioned. According to sociologist Herbert J. Gans, ${ }^{8}$ even though journalists attempt impartiality, implicit values are inextricable from the news, in terms of selecting stories, accessing sources and asking certain questions. Was AP's commitment to objectivity compartmentalized as Daniel Hallin has argued $?^{9}$ In addition to six $\mathrm{AP}$ journalists and an $\mathrm{ABC}$ reporter, two scholars and a medical doctor who treated war casualties are interviewed for this chapter. All spoke on the record. AP journalists are asked if they were under pressure from senior editors, their government, the Israeli military, PLO, or others to report certain stories or omit others. How were pressures, if any, demonstrated? Did they make any effort to challenge these pressures or resist them? How did these pressures impact coverage? Were journalists, as scholars contend, constrained by their allegiances to professionally shared values? The power of top editors, Gans maintains, is maintained by organization-wide pressures for conformity. The chapter will also try to determine if American journalists, as Gans argues, consciously or unconsciously subscribe to and crystallize America's dominant values of politics and society. ${ }^{10}$

This chapter takes a small sample of AP stories - 20 in all - filed during the invasion, beginning with June 4, 1982 (as cited above) when Israel attacked Lebanon two days before a full-scale land, air and sea invasion that lasted two months. In 
analyzing each story, I use the yardstick introduced in the previous chapter to establish news objectivity. The sample of stories is used as a template to establish a pattern of how AP reported the invasion, dissecting almost every paragraph (even sentences if necessary) to look for the dominant narrative, source selection, timelines, employment of specific terminologies, and presence or absence of context and background and the use of value-laden language. The details of the results of the survey are addressed at the end of this chapter. Generally, AP's source selection shows that it retained its neutrality for the most part with regard to the developing news relating to the fighting. However, this attempt at "balance" reporting was hampered by the dominant narrative that explained the eruption of the war and the reasons behind it only from Israel's view. The stories filed in the early days of the war showed that little attempt was made to bring an accurate presentation of context and background. The dominant narrative generally repeated without skepticism or challenge Israel's official justification for going to war: retaliation for the assassination attempt on Israeli ambassador Shlomo Argov in London; and that Israel was acting in self-defense to stop PLO attacks on northern Israel. The AP stories did not spell out that Argov's attackers did not belong to the PLO, and did not explicitly identify them as enemies of the Palestinian group. This narrative was misleading because it presented Israel as the victim and justified for a) retaliating against the PLO (even though for the first 24 hours it was not determined who had shot the ambassador) and b) taking preventive action to stop guerrilla rocket attacks. Even if AP did report Israel's claim on the first day that it was retaliating for the shooting in 
London, it could have also explained - preferably in the lead where the Israeli claim was cited - that it was yet unclear who carried out the London attack. Whether it was negligence on the part of the writer or editor who were under extreme pressure to move the urgent stories on the wire, the story on the eruption of the 1982 war was poor in context, skepticism, background, and led to a misleading narrative that would continue for days and weeks to come.

As the war escalated - and after the Israelis laid siege to Beirut - and civilian deaths mounted, stories became more critical, skeptical, and challenged many of Israel's narratives, such as the human shield allegation, its denial of using cluster and phosphorous bombs, or deliberately targeting the civilian population. Journalists kept a skeptical attitude when PLO and later Israeli officials tried to feed them with propaganda. They were generally professional, thorough and comprehensive. There was a great deal of emphasis on human stories.

AP Beirut was the news agency's main Middle East bureau run by Nicolas B. Tatro, who was on assignment in Yemen when Israel invaded. His wife, Earleen Fisher, ${ }^{11}$ a correspondent, took charge of the operation with the help of Mideast news editor Tom Baldwin. In the main newsroom, Farouk Nassar, AP's veteran Lebanese journalist and main spot news writer, pounded out bulletin after bulletin on an old typewriter. His copy was typed by a staffer on a telex machine - a teletypewriter connected to a telegraph that operated like a typewriter - in an adjoining room and filed through a teletype machine to a wire that went directly to New York headquarters where decisions were made on whether and in what form the 
stories would be disseminated to subscribers in the U.S. and elsewhere in the world. Most communications with headquarters were conducted via a private inter-AP message wire. New York sent queries by message about a story and Beirut answered by message - partly because telephone service was unreliable in Beirut and partly because messages were much cheaper than international telephone calls. AP staffers in the bureau usually did not see what went to American clients until weeks or months later, when a package of newspaper clippings arrived by mail and they saw the changes that New York editors had made to their stories.

The AP relied on local radio and newspaper reports for preliminary information, as well as on a network of stringers in various cities and government agencies (police, the president's office, parliament, etc.). The bureau could then decide what to use and whether to send a staffer to look for more details. The main An Nahar daily was the most authoritative, but like other publications that were politically influenced, it was under pressure from Syria and the Christian or Muslim militias to conform to their politics. "You had to read between the lines," says Tatro (Appendix A, 27), and “we had pretty good discussions. We weren't afraid to analyze. We were pretty good at it I thought for not going too far." 
All senior editors and correspondents interviewed agreed AP's New York headquarters rarely, if ever, interfered with their coverage of the invasion. "Basically we decided internally what the story was," recalls Tatro. "I don't remember getting any guidance from the outside about it, from headquarters or anywhere else. I think we had a real good sense of what was going around, talking to diplomats and so forth. ... [Today], there are people micromanaging you and using what they learned at journalism school and all that to try to organize the newsroom and great emphasis on management, not so much emphasis on leadership."

GG Labelle (Appendix A, 13), Middle East news editor from 1983 to 1985 and again in the 1990s, describes AP Beirut's operation in the early 1980s:

Since we thought of the Beirut story as an important one, we tended to cover every event we could. This was not discouraged by New York headquarters since, if it used the day-to-day story at all on any given day, it edited the story as it saw fit for distribution outside the Middle East.

Ellen Nimmons (Appendix A, 20), current assistant international editor in New York, was new on the foreign desk in 1982:

We couldn't even call Beirut. We had to use the message wire. This probably increased the independence of the bureaus. ... In NY, we of course edited the stories, we had control as far as get it through the desk (the American wire and world wires ran from New York). There were stories that would come in and we'd say 'what?' 'what do you mean by this, why are you saying that?' It was really difficult. We could hold things up or we could change them, but in terms of directing the coverage, not so much.

In 1982, the dominant narrative was: "Will Israel drive the PLO from Lebanon and dominate Lebanon?” says AP's Charles J. Hanley (Appendix A, 8), who covered 
the war from the Israeli side. Based on my search of some of the dispatches that will be demonstrated later in the chapter, the AP identified Israeli targets as PLO "strongholds," yet the casualties were most of the time civilians. According to Chomsky, after the "initial bombings on 'predetermined PLO. positions' and 'PLO strongholds' in the terms pronounced appropriate by General Sharon, and adopted by Israel's American supporters, and an early example - in this war - of how the IDF never aims at civilian targets, as Begin explained while recalling the familiar military doctrine of punishing the civilian population.

According to Chomsky, each successive war brings new levels of ferocity and destruction. To make his case that Israel hit the civilian populations deliberately in 1982, Chomsky refers to General Mordechai Gur, Israel's former chief of staff and member of the Labor Party, as admitting in a 1978 newspaper interview that his army did not make a distinction between civilian and non-civilian population in its wars with Egypt, Jordan and during its 1978 invasion of Lebanon. ${ }^{12}$ "Do you think that I pretend not to know what we have done all these years? What did we do the entire length of the Suez Canal? A million and a half refugees! ... Since when has the population of south Lebanon become so sacred? They knew perfectly well what the terrorists were doing. After the massacre at Avivim, ${ }^{13} \mathrm{I}$ had four villages in south Lebanon bombed without authorization." 14 The interviewer reminded Gur that military communiqués always spoke of returning fire (retaliating) and of counter strikes against "terrorist objectives," to which he replied: "Please be serious. Did you not know that the entire valley of the Jordan had been emptied of its inhabitants as a 
result of the war of attrition [1969-70]?"15 Asked if he believed the population should be punished, he said: "Of course, and I have never had any doubts about that. When I authorized Yanouch [diminutive name of the commander of the northern front, responsible for the Lebanese operation] to use aviation, artillery and tanks [in the 1978 invasion], I knew exactly what I was doing. It has now been thirty years, from the time of our Independence War until now, that we have been fighting against the civilian [Arab] population which inhabited the villages and towns, and every time that we do it, the same question gets asked: 'should we or should we not strike at civilians?"”16

The significance of Gur's remarks, said Israeli military analyst Ze'ev Schiff, "was the admission that the Israeli army had always struck civilian populations, purposely and consciously." 17

Prime Minister Menachem Begin in 1982 referred to the above comments made by Gur during a Knesset debate in response to Labor Party legislators who were criticizing him for bombing civilians in Lebanon. ${ }^{18} \mathrm{He}$ reminded them that similar atrocities had also occurred under the Labor government, said Chomsky. The remarks in 1979 "apply with considerable accuracy to the Lebanese invasion four years later, and with still more force," wrote Chomsky, adding that the military doctrine of attacking defenseless civilians derived from Israel's first prime minister, David BenGurion's advice. ${ }^{19}$ "What is necessary is cruel and strong reactions," Ben-Gurion wrote in a January 1, 1948 entry in his Independence War Diary. "We need precision in time, place and casualties. If we know the family, strike mercilessly, women and 
children included. Otherwise the reaction is inefficient. At the place of action there is no need to distinguish between guilty and innocent. Where there was no attack - we should not strike. ${ }^{20}$ And all the while, wrote Chomsky, the press in the U.S. was regularly "accused of failing to recognize the amazing and historically unique Israeli efforts to spare civilians and of exaggerating the scale of the destruction and terror."21 What actually happened in the days and months before and immediately after Argov's shooting in London is vital to establish media's dominant narrative, sourcing, story selection and selective contexts. What was rarely indicated in the stories was that the Israeli Cabinet, less than 24 hours before the attempt on Argov had voted on a full-scale invasion. The vote took place five hours and 40 minutes before warplanes bombed Beirut. ${ }^{22}$ While Scotland Yard had not yet revealed the attackers' identities, Israeli intelligence strongly suspected, but did not disclose, that the anti-PLO Abu Nidal, ${ }^{23}$ who masterminded the killing of scores of Jews and fellow Palestinians in the 1970s and 1980s and who was no friend of the PLO, was behind the attempt. But the Israelis did not disclose this important information. Four days later, even when it was officially established who was responsible, the AP's dominant narrative remained the same.

Why did the AP not distinguish between the PLO and Abu Nidal? Fisher (Appendix A, 5) says Beirut mentioned it prominently in the copy but believes New York editors took it out. It was only an error of judgment for "not knowing or caring about the difference between the gazillion flavors of Palestinians," and "not a conscious effort to whitewash Israel." Also, she says, explaining it "would take up 
precious paragraphs of space." Nimmons (Appendix A, 20) says it was certainly not done "purposely to make it wrong."

More importantly, why did the AP not establish early on that the PLO had not violated the ceasefire for 11 months? "I was under the impression that we were saying [these] in our copy out of Beirut," says Fisher. "There was the 1981 mini-war ${ }^{24}$ that lasted a couple of weeks and then it was like nothing seemed to happen from then until [the invasion]." She says the Tel Aviv and Beirut bureaus wrote separate stories throughout a given day and often New York wrapped up the stories from each bureau into one for the morning American papers. "Given the communications, we didn't know what was happening to the copy."

Stephen K. Hindy (Appendix A, 10), AP's Middle East news editor from February 1979 to September 1981, disputes the assertion by Noam Chomsky, ${ }^{25}$ whose research of the Lebanon war goes deeper than any other contemporary work, that the media failed to report Israel's frequent ceasefire violations before the invasion, and insists the AP did report routinely Israeli shelling of southern Lebanon. "No one ever said don't cover this. We sent the stories," says Hindy, "but I have the feeling they weren't getting much attention because it was kind of same old things over and over." However, he cannot remember if the AP, himself included, specified that the Israeli shelling violated the ceasefire, or whether the copy mentioned the PLO had adhered to the truce. "Ceasefire didn't have much meaning," says Hindy. "There were a handful of PLO attempts to infiltrate [Israel], but it was overwhelmingly attacks from Israel.” Besides, explains Tatro (Appendix A, 27), Palestinians were not militarily 
inactive in south Lebanon before the invasion. By the end of the 1970s, they were running a virtual state-within-a-state in Lebanon.

For months prior to the invasion, Israeli analysts had been speculating that Defense Minister Ariel Sharon was planning to go to war and was waiting for the opportune time to execute it. ${ }^{26}$ Following Sharon's visit to Washington in mid-May 1982, Pentagon officials leaked to U.S. journalists details of the plan. Clearly, the invasion had been plotted long before the attempt on Argov. Sharon's grand plan envisaged that after destroying the PLO in Lebanon, Israel would prop the Christian Phalange and manipulate the Lebanese parliament in the August vote to install its ally Bashir Gemayel as president. ${ }^{27}$ Sharon and Gemayel met as early as January 1982 to plan the invasion. ${ }^{28}$

With the mounting of civilian casualties, media coverage of the invasion became more critical of Israel, to a point that Israel had to regularly defend itself or deny damning reports about its actions - such as using phosphorous and cluster bombs $^{29}$ against civilians. Meanwhile, Israel's supporters in the U.S. waged an aggressive campaign to discredit the media, especially the TV networks. ${ }^{30}$

There was an "opening" during the war and for almost a year afterward when journalists were able to engage in independent reporting, say Hindy (Appendix A, 10) and former $\mathrm{ABC}$ News correspondent Charles Glass (Appendix A, 7). Hindy believes the opening was perhaps because many of the Israel-based journalists were reporting from Lebanon during the war and witnessed what was happening first-hand. Before that, Hindy refers to the overall AP coverage as biased toward Israel. Most of all, he 
remembers tension over stories with AP colleagues in Tel Aviv. "We were always fighting with the Israeli point of view. It was extremely frustrating because we would actually be there and see things, and see shelling and see wounded people and then the Israeli military spokesman's account would be given equal weight to our eyewitness account. ... The frustration I had was that when it got to the foreign desk and it got to the A-wire, the Israeli military spokesman would be given as much credibility as the guys who were on the ground in Lebanon."

The "tug of war" between AP's Tel Aviv and Beirut bureaus was relentless. There were no direct telephone lines between the two countries since they were technically at war - so the only way the two bureaus corresponded was via AP's message wire. Tel Aviv would, for instance, tell Beirut, “'Hey, this is what the Israeli military spokesman is telling us' in an attempt to discredit Beirut's reports," says Hindy. "We had a dueling story on virtually everything. It was a tug of war and they won. ... I think New York more often than not sided with Tel Aviv."

Hindy cites an April 18, 1980 incident to demonstrate the tense working relationship with the Tel Aviv bureau: A UN convoy he was traveling in was ambushed by Lebanese militiamen who later killed two Irish soldiers and injured a third. In his story, Hindy identified one of the gunmen as a member of an Israelibacked militia. However, it was challenged by the Tel Aviv bureau because the IDF had denied the gunmen were Israeli allies. ${ }^{31}$ New York went with the Tel Aviv version and referred to the abductors as "Arab villagers." 
The "tug of war" and the underlying tensions between the two bureaus offer a unique insight into the working of competing views, narratives and interpretations of the same event. It sheds light on how news is conceived, and it details the reporting and writing process, selection of sources, and the powerful role of gatekeepers. It also highlights, if not necessarily ideological influences, political factors at play. In the case of Hindy, as an eyewitness, he was the primary source of the report. He had knowledge and experience of the area and spoke Arabic. He used a UN officer, who identified at least one of the gunmen, as his source. In addition, he interviewed the UN commander for an official comment. The Tel Aviv bureau chief, the late Frank Crepeau, on the other hand, used the Israeli military as the primary source, which he trusted more than the UN. "I was there, they could not deny what I saw, but in spite of that, the story they wrote ended up ... putting a big spin on my story."

In the 1982 war, Israel's strategy was to force PLO fighters into West Beirut and lay siege to the capital, cutting off water, food, fuel, medical supplies, and electricity as it bombarded it, a strategy presumably to force the PLO to surrender and turn the population against it. ${ }^{32}$ The AP kept the bureau open in West Beirut, where communications were in tatters, causing a great deal of difficulty for journalists to function. Says Tatro (Appendix A, 27):

We had that famous situation in the Commodore Hotel ${ }^{33}$ which had a telex machine. We had a dedicated [telephone] line - a telex machine [that] lasted a long time, but we had run out of ribbons and we ran out of paper. So you could go and type on it but you had no idea what anybody would say and respond. You were never sure if you really communicated or left just a bunch of garble on the telex back at headquarters. 
Tatro and AP's technician Francois Ghattas went to Beirut's Post, Telegraph and Telephone (PTT) offices to check the problem. In the basement, Tatro (Appendix A, 27) says, they found the incoming international circuit had been intentionally axed, apparently by the Israelis.

Copy from Israel, mostly accompanied by alert bells that ensured their urgency, carried a sentence at the top of each dispatch that the report had been submitted to the Israeli military censor. ${ }^{34}$ In some cases, the agency said the censor had ordered material removed. Israel-based reporters were only allowed north into occupied Lebanon under Israeli military escort and had to submit their dispatches to Israeli censorship. There was no formal media censorship in Lebanon. Journalists had unimpeded access to battlefronts (except for some of the Israeli positions), bombing sites, hospitals, and victims. They were able to interview with little restriction civilians, fighters, politicians and militia leaders. However, TV footage from Beirut that had to be sent to Israel for transmission (unable to file from Lebanon for technical reasons) could be censored by the Israelis before being filed to headquarters. It was easier for print reporters. Hanley, who traveled with the invading army to occupied Lebanese areas in the south, says the Israelis "were simply escorts into the war zone, after which we were able to do what we wanted. As for Israeli censorship, I recall only one instance ... It was simply the deletion of the specific location on the Golan Heights from which I was reporting on deployment of American volunteers in defensive positions." There was PLO meddling, says Tatro. 
There were intimidations and pressures from PLO officials, including a blind man with a gun from the Popular Front for the Liberation of Palestine (PFLP) who used to brief journalists in the lobby of the Commodore Hotel along with one of their older diplomats.... PLO officials would ask questions such as: 'Are you going to talk to the Israelis? Where do you stand with Arafat on this?' They came with some message. But Arafat's Fatah group did not come to the Commodore. Reporters had to go to them at their offices with questions or for interviews. ... They were sort of rigid, like the Russians, difficult interviews because they always gave you the propaganda.

Press reports and video footage of civilian casualties; routine interviews with doctors, the International Committee of the Red Cross (ICRC) and other humanitarian relief groups, filled Western newspaper pages and television screens. The coverage provoked international condemnation for the brutality of targeting civilians, hospitals, orphanages and other civil institutions. It was no surprise then that Western, especially American, media coverage of the 1982 invasion drew strong criticism from Israel and its U.S. supporters, who accused them of anti-Israel and pro-PLO bias. ${ }^{35}$ They specifically disputed casualty figures because they were provided by the Lebanese police, Lebanese government, the PLO, and international relief workers. (Lebanese government casualty figures were based on police records that were based on hospital counts, as well as civil defense centers.) At the same time, media scholars, such as Chomsky, accused the same media of being pro-Israel. Based on a random survey of American press and television reports, I discovered that the "anti-Israel" charges appeared to center on stories filed from Lebanon, while most of the "antiPLO" stories originated in Israel or in in the U.S, mostly as editorial or opinion 
pieces. ${ }^{36} \mathrm{TV}$ networks reporting from Lebanon bore the brunt of Israeli military censorship - and the ire of pro-Israeli supporters in the U.S. ${ }^{37}$ Perhaps one of the strongest and most critical reports about Israeli actions in Lebanon was a dispatch by NBC's John Chancellor, standing on the roof of a building in Beirut on August 2, 1982 in which he referred to the invading army as "imperial Israel" carrying out "savage"38 attacks on Lebanon. "What's an Israeli army doing here in Beirut? The answer is that we are now dealing with an imperial Israel, which is solving its problems in someone else's country, and world opinion be damned." He compared that day's fierce bombing of Beirut to Nazi aerial attacks during the Spanish Civil War. ${ }^{39}$ (Note, Prime Minister Begin in justifying his invasion, compared Arafat to Hitler. $)^{40}$

On June 25, a report by ABC's Richard Threlkeld began with footage of Israeli Prime Minister Menachem Begin speaking to a nearly empty United Nations General Assembly - in an effort to bring home the unpopularity of Israel's war. The 3.9-minute video ${ }^{41}$ also showed Threlkeld speaking from a devastated neighborhood in south Lebanon, interspersed with shots of an injured child being carried away. The same report showed displaced civilians and a coffin. For context, Threlkeld referred to the plight of Palestinian refugees since the 1948 establishment of the state of Israel: "The war has turned many of them back into refugees," because they had no home to go to. A brief background to Israeli belligerence, such as the annexation of Arab East Jerusalem and the Syrian-occupied Golan Heights, both captured during the 1967 Arab-Israeli War, and the building of Jewish settlements on the occupied Palestinian 
West Bank provided the bigger picture. He weaved in Israel's goal of having its Lebanese Christian allies run the country. Israel, he said was perceived as "a neighborhood bully." 42

Such details, and elaborate context, would be rare today in mainstream media reporting of a similar conflict, such as the 2006 Israel-Lebanon war, the 2008-9, 2012 and 2014 Israel wars against Gaza. More importantly, the harsh references to Israel would be almost impossible.

NBC was singled out by pro-Israel supporters in the U.S. scrutiny. A documentary called "NBC in Lebanon: A Study of Media Misrepresentation" sponsored by the American Jewish group “Americans for a Safe Israel” accused NBC of "faulty coverage. "We see NBC film clips of ruined buildings; we hear correspondents saying they were not military positions. The implication is that Israeli artillery fire was always indiscriminate," said the documentary that came out in 1983. NBC Nightly News, it said, relied overwhelmingly on anti-Israel subjects for its interviews. ${ }^{43}$ It is odd that journalists were expected to search for pro-Israelis in towns and cities under deadly attacks. One might ask whether the media was criticized for not looking for sympathizers of the $9 / 11$ hijackers from among their victims.

Meanwhile, the documentary praised other journalists, including New York Times' David K. Shipler who reported that the PLO frequently used civilians as cover and placed its weapons and ammunition in densely populated civilian areas "in the hope that this would either deter Israeli attack, or extract a price from Israel in world opinion for the killing of civilians." 44 
In a February 18, 1984 opinion piece in the New York Times, John Corry, who mainly supported the views of the documentary, offered his thoughts: "Television journalism has a dynamic of its own; it can be a captive of its own images. The images of collapsed buildings, ruined streets and grieving civilians make a good story. Indeed, they become the whole truth of the story. Journalism, in general, suffers from a lack of memory, and television journalism suffers from it grievously." ${ }^{45}$ Corry was right when he said images are presented without context, as is also the case with stories that appear supportive of Israel, a lack that not only is true with TV reporting on the Middle East, but also print. Corry concluded: "NBC, along with $\mathrm{CBS}$ and $\mathrm{ABC}$ - whose coverage, according to the documentary, was only marginally better - compresses daily history into 22 minutes each night. Events have no past. The PLO had no history of terrorism and murder; Lebanon was not an ancient battleground. Truth was born anew each night. 'NBC in Lebanon' is flawed; it is also disquieting for people who watch the evening news." ${ }^{46}$

Another major critique was voiced in a report by the controversial Jewish AntiDefamation League of B'nai Brith (ADL) $)^{47}$ that lashed out at U.S. TV networks for using inadequate sources for civilian casualties. "Who are "Lebanese police,", "Who is the 'Lebanese government,"' asked the October 1984 report, directing its anger specifically at casualty figures cited by $\mathrm{ABC}$ and $\mathrm{NBC}$ on June $4 .{ }^{48}$ It ridiculed CBS for quoting "international relief officials" in Beirut who reported casualty figures in Sidon. "Who are these 'international relief officials,' and if they are in Beirut, how could they be reporting 
on casualties in Sidon?"49 It did not, however, say where the media were supposed to obtain the figures.

Martin Peretz, editor of New Republic and a supporter of Israel, said Israel had "lost" the press years before 1982, because "most journalists are young people of the Vietnam generation whose sympathy is always granted to anyone who calls himself 'a guerrilla' or a 'freedom fighter'" (an apparent reference to the PLO), and that television simply 'makes the problem worse." "50

Pro-Israel critics in the U.S. and elsewhere claimed that news organizations were deceived by the PLO's sophisticated and elaborate propaganda machine that exploited the suffering of children ${ }^{51}$ - a claim ridiculed by journalists and others with extensive experience of PLO's incompetence in public relations. Earleen Fisher (Appendix A, 5) refers to some of the PLO officials' unsophisticated PR efforts, including a claim by spokesman Mahmoud Labadi that the Israelis had let loose poisoned balloons over Lebanon to harm children. "Anybody who had ever dealt with the PLO's so-called information officers knew that it was next to impossible to get anything plausible or credible out of them, especially when it came to [casualty] numbers. ...It was a combination of propaganda and incompetence." While the mainstream narrative of "bad Arabs" against "good Israelis" - long the dominant narrative in America - was temporarily interrupted, it did not, however, necessarily mean the media became pro-PLO or anti-Israel. They became as "objective" as any media could be. Professor Julie Peteet explains: "Anything, regardless of its quality that allows the articulation of the Palestinian experience is 
seen as pro-Arab propaganda and anti-Israel." ${ }^{2} \mathrm{ABC}$ 's Glass (Appendix A, 7) says skepticism about Israel was mainly due to the fact that the media were surprised to see Israel behave that way:

There was a lot of pretending that Israel had somehow changed, that it had lost its soul and so forth, which as we know wasn't true. In 1948 they expelled three-quarters of the population of Palestine, in 1967, they expelled hundreds of thousands of people from the West Bank, incarcerated people in Gaza, they began a program of colonization of stealing land and demolishing houses and putting in settlements - most of which was completely ignored. ${ }^{53}$

Labelle (Appendix A, 13) believes perceptions of bias may have had to do with source selection:

Stories filed from Lebanon, Israel and the U.S. were different in tone and emphasis and what was perceived as fact. That would be natural given that U.S. stories were based on quotes from American officials, Israeli-datelined ones on statements by Israeli government or military officials, and those from Lebanon on events on the ground and Palestinian and Lebanese sources. Even foreign reporters in Lebanon with the IDF would see things differently than foreign reporters watching the invasion from the Lebanese side. This has long been a complaint of AP editors in New York - that they get different stories from Israel and Lebanon about the same events.

Also, the Reagan administration's position during the war was not always on par with Israel's, especially after the number of civilian deaths increased. For this reason, says Tatro (Appendix A, 27), American media did not hand Israel the same "carte blanche" it had before the war. Mainstream media "tend to very closely do whatever the government position is," says Chomsky (Appendix A, 4) in an interview with me. "The government's position sometimes changes, so the media interpretation changes. ${ }^{\circ 4}$ 
Pro-Israeli commentator Daniel Pipes' explanation of the critical reporting in 1982 resonates with Glass's argument, though while Glass believes it was because of journalists' disillusionment in Israel, Pipes complained that Israel was held to “impossible moral standards" because of America's huge interest and familiarity with Israel and Jews - "in contrast to the alien quality of Muslim life." 55

One of Israel's contentious allegations was that the PLO used civilians as human shields, a charge that Israel has often used in its conflicts with Arabs. A July 26, 1982 statement by the Israeli Embassy claimed the PLO had "entrenched themselves in the heart of residential West Beirut ... creat[ing] acute danger to the safety of the Lebanese as well as Palestinian men, women and children from behind whom these PLO forces are sending out volleys of artillery and small-arms fire against the Lebanese and Israeli forces in East Beirut and beyond" in "blatant violation of the rules of warfare." 56

Labelle (Appendix A, 13) says the media usually report the "human shield" charge as an accusation. "It's hard to see a way around that. The best a reporter can do to verify or refute the accusation is to quote authorities on the other side, or local people. It's hard to absolutely do either since reporters are usually not on the scene before an Israeli attack to see in person what was happening at the time."

While some of the claims may have been true in 1982 - as in the case of a school in the southern city of Sidon - this was not always so. Fisher (Appendix A, 5) investigated an air raid on the school that killed at least 120 Lebanese and Palestinian civilians, mostly women and children who had fled Israeli bombardment of Tyre, a 
city to the south. She found that PLO fighters had placed a T-54 tank outside the school. Hospitals, clearly marked with Red Cross signs on the roofs, were not spared either. Doctors denied that guerrilla guns were positioned next to them. Toward the end of the war, of West Beirut's 17 hospitals and emergency centers, 12, including International Committee of the Red Cross's (ICRC) emergency field hospital, had been forced shut after coming under Israeli shellfire, and because of lack of medical supplies due to the siege.$^{57}$ Dr. Amal Shamaa (Appendix A, 23) is adamant that the Israelis intentionally shelled hospitals, including Berbir where she worked, for five consecutive days, preventing medics from leaving the hospital and forcing them to live in the stench of decaying bodies. Her assertion at the time was widely reported. Media reports of Israel's use of phosphorous bombs against civilians were perhaps some of the most damaging to Israel's reputation and credibility. Israel denied using them on civilians until journalists saw dying and dead victims. Dr. Shamaa was one of the first medics to draw attention to the use of phosphorous bombs. AP reporter Terry Anderson (Appendix A, 1) on July 19 watched as Dr. Shamaa tried in vain to save a three-year-old boy from burning phosphorus that had hit his refugee camp a day earlier:

Three-year-old Ahmad Baytam, his face and part of his chest covered with severe burns, was tied to the bed with soft bandages. As Dr. Amal Shamaa leaned over to point out the injuries caused by burning phosphorous, his heart stopped.

The doctor bent over his body and put her stethoscope on his chest, then called to a nurse and medical orderly, "Arrest." The slim, intense pediatrician began pushing hard on the wounded chest, while the orderly started breathing into his mouth. The nurse ran for heart needles 
and an electro-shock machine. Dr. Shamaa ... leaned against a wall. "It was respiratory damage. They inhale the phosphorous," she said. ${ }^{58}$

According to Lebanese government figures, nearly 18,000 civilians ${ }^{59}$ were killed ${ }^{60}$ in the war. ${ }^{61}$ Israeli Chief of Staff Rafael Eitan said 117 Israeli soldiers had been killed "in the entire western sector of Lebanon." 62 Eight had died in Beirut, three in accidents. Israel's estimate of the Lebanese dead was 930, including 340 civilians. The number of PLO fighters killed was given as 4,000. These figures were generally ridiculed by reporters and relief workers. In Israel itself, casualty figures drawn from Lebanese sources were regularly cited. Army credibility was at such a low, wrote military correspondent Hirsh Goodman, that "thousands of Israeli troops who bear eye-witness to events ... have taken to listening to Radio Lebanon in English and Arabic to get what they believe is a credible picture of the war." ${ }^{93}$

With foreign news, implicit American values dominate the reporting in U.S. media, even as journalists try to be impartial, according to Herbert Gans. Journalists often express dominant political ideology unconsciously. The AP, while an American agency, has hundreds of non-American staffers. Is the AP then less driven by American values than other mainstream U.S. news organizations? Tatro (Appendix A, 27), an American, partly agrees with Gans' theory, but says it is more complex than that:

There was some definite personal influence on what we did, but how we did it was an empirical process. ... We had strong values about the need for attribution, the need for reliable sources and verification of what they had to say and check out reports. We were reactive in many ways, but that was I think valid. People liked questions. It was part of the public debate: what happened? what's going on? did they really do 
this - such as the human shield business. And we go and check. Were the Israelis responsible for turning on and off the electricity in Beirut? You go to the electric company and find them sitting in their chairs. I guess they were. So we did things with a very empiricist approach. Now whether the Chinese or the Russians or the Lebanese themselves would cover the same way, I suppose not. They're coming from a different interpretation of what's going on in their minds. They might cover different aspects, but if you have an empirical way of reporting, what you're going to do is valid. We had the biggest collection of nationalities. It was dominated by Americans only because you had an American leader. We thought for the world, so these were the questions that came to us. Maybe there were different questions at different places that would have led to different stories being written; no question. But you can't cover everything. There are times that you need to note that depending on the context of the story and not knowing the culture or not knowing what's going on on the ground often leads people astray. It's not necessarily the reporting they are doing is bad, it's the incompleteness of the story. Honestly, whoever was doing it has a reason, has a motivation. That needs to be part of the story, but that's just an empirical approach that will save you from that kind of mistake. If people don't know what the local culture is and don't have any idea what an international audience think about such things, they might not choose to explain it, but I think most good reporters would.

In 1982 , there were about 10 American and the same number of local staff in Beirut at one point or another. The local staff knew they were expected to deliver what the American audience could understand, therefore the news was mainly from an American perspective even if the coverage may have seemed too simplistic or lacked context. As a young journalist, I was under the impression that since the U.S. enjoyed a free press, our reporting was, therefore, the best possible. No questions were asked - not yet. Even the missing context or background in stories did not raise eyebrows at the time - not even some of the latent or obvious signs of "bias" in the copy. It seemed only natural that American or Western values dominated the coverage. 
Fisher (Appendix A, 5), an American:

In Lebanon, it's not a war that involves your own country directly and I remember a great frustration at thinking that there seemed to be people in the United States who thought it was a good guy-bad guy story and the Israelis were automatically the good guys. Part of that is just the product of the era. I mean everybody had seen the movie, Exodus or The Ten Commandments, in which Moses was the good guy and by derivation the Israelis were the good guys. But it was not as simple as that.

Weeks of arduous negotiations to end the war were conducted in secret, often under Israeli fire. On August 12, Arafat finally agreed to Israel's condition for ceasefire to leave Beirut after the Americans gave assurances that the tens of thousands of Palestinian civilians left behind in refugee camps would be protected by a multinational peacekeeping force (MNF) stationed in Lebanon. On August 23, Parliament elected Bashir Gemayel, Israel's ally and enemy of the PLO - as the new president of Lebanon. Gemayel was to take office the following month; Israel's remaining goal was to sign a peace treaty with Lebanon that would entail the withdrawal of Syrian forces and prevent the PLO from returning to Beirut after Israeli forces withdrew from Lebanon.

After 12 years in Beirut, the PLO leader began his next exile in Tunisia. On September 10, the U.S. Marines withdrew from Beirut, followed by the French and Italians. The Lebanese Army began to move into West Beirut. But the war was far from over. Immediately after he was elected, Gemayel repudiated earlier promises to Israel, informing it that a peace treaty was inconceivable as long as the Israeli army or any other foreign forces remained in Lebanon and that it could be concluded only 
with the consent of all Lebanese factions. On September 14, Gemayel was assassinated in a massive explosion that leveled the Phalange Party headquarters, putting the entire Israeli project in Lebanon in jeopardy. Gemayel's brother, Amin, who was hostile to the Israeli presence in Lebanon, was elected president with U.S. backing. ${ }^{64}$

As we have seen, a great deal of the 1982 war coverage was dictated by dysfunctional technology that largely stemmed from power cuts. Telephone lines were almost non-existent, resulting in either relying on information provided by local radios and stringers, or journalists risking their lives and venture out into the war zones to bring the news. The Beirut bureau and New York headquarters were virtually cut off from each other; Beirut-based journalists did not see New York's edit of their copy, which at times did not reflect their reporting. New York, unfamiliar with the story, for example, edited out some vital information because it may have been too confusing, such as the identity of the attackers who shot and injured the Israeli ambassador in London. Original stories filed by Beirut are unavailable, therefore, the word of the journalists interviewed are taken for granted. What everyone agrees is that there was no interference from headquarters in the coverage of the war. Journalists selected news and sources depending on the event.

To measure objectivity in AP stories by using the yardstick established in Chapter One, I surveyed a sample of 20 stories: four spot news from Beirut (June $4,{ }^{65}$ $22,{ }^{66} 23,{ }^{67}$ and 24, 1982) and two features (July $9^{68}$ and August $10,{ }^{69} 1982$ ); seven from Tel Aviv (June 9; ${ }^{70}$ July 25, ${ }^{71}$ August 14 ${ }^{72}$; September 15, $22,{ }^{74} 25,{ }^{75} 25,{ }^{76} 1982$ 
- all but one brief sidebar were analyses); two one spot stories (wrapped up in New York, June $8,1982^{77}$ ); from Washington (June 11, 1982 ${ }^{78}$ ); one spot from Damascus (June 11, 1982 $2^{79}$ ); one spot from Moscow (September 20, 1982 ${ }^{80}$ ); and one spot from Havana (July 30, 1982 ${ }^{81}$ ). Two of the Beirut-dated stories were the only ones from Lebanon during the war that I could find in LexisNexus. A search of Google also found three stories, including one feature, all published in American newspapers. Most of the other stories on the war were Israel-dated. The survey found the following:

a) Source selection: local Lebanese radio and newspaper reports, breaking news tips from AP stringers around the country, and first hand reporting by a large team of AP reporters and photographers from various battle fronts and other locations. Sources for the day-to-day battles and progress of the war included prominently the Israeli army. In addition sources included the official Palestinian WAFA news agency and PLO statements that were obtained with difficulty. The AP Beirut made its own list of casualties that were painstakingly drawn from the Lebanese police, Lebanese civil defense and the local Red Cross, as well as the International Committee of the Red Cross and other international and Lebanese relief agencies. In addition reporters made daily visits to hospitals.

b) Dominant narrative: in the early days of the invasion, the narrative was that Israel was retaliating for the assassination attempt on its ambassador in London. The AP generally repeated without skepticism Israel's public justification for 
going to war, which was also alleged to be acting in self-defense to stop PLO attacks on northern Israel.

c) Context and background: The context for the days and months before and immediately after Argov's shooting in London is vital to establish media's dominant narrative, sourcing, story selection and selective contexts. What was rarely indicated in the stories were: a) the Israeli Cabinet, less than 24 hours before the attempt on Argov had voted on a full-scale invasion; b) the history of Lebanon-PLO-Israel situation dynamics: since mid-1981, the PLO had adhered to a U.S.-negotiated ceasefire, while between August 1981 and May 1982, Israel made 2,125 violations of Lebanese airspace and 652 violations of Lebanese territorial waters. ${ }^{82}$ Therefore, the suggestion that Palestinian rockets had been raining on Israel before the invasion was inaccurate. It appeared in passing and only as part of another context: "The UN peacekeepers were supposed to provide a buffer between the Palestinians and Israel, but the guerrillas eventually infiltrated back into the area." ${ }^{83}$ Even here, the context was one-sided, giving credence to Israel's justification. However, by June 22, the AP had added another context in addition to Israel's justification: "The invasion was launched June 6 with the stated goal of driving the Palestinian guerrillas 25 miles back from Israel's border (the reference to "Israel's stated goal appeared to be a template for most AP copy during the war), but the invasion army drove all the way to Beirut, 50 miles north of the border, and appeared intent on destroying the guerrillas' Beirut nerve center." ${ }^{84}$ Here, it is not clear whether Israel's stated goal was a lie or 
that Israel had changed its mind after invading. A June 11 story out of Washington about Israel's supporters and critics in the U.S. Congress had all the ingredients of an "objective" story. The lead read: "Congressional supporters of Israel mustered their forces Friday while critics spoke out sharply against Israel's use of U.S.-supplied weaponry in its invasion of Lebanon." ${ }^{85}$ It went on to say that five senators had sent a letter to President Reagan stressing the need for "mobilizing quickly America's diplomatic resources to assist in restoring unity and full independence to Lebanon." What stands out in the story is the "balance" - it mentions U.S.-supplied weapons, especially in its lead - and goes on to mention it three more times - something rare in the past and for certain today. The weapons included cluster bombs that the US delivered to Israel under conditions for usage, i.e. to target tanks and military vehicles. It is interesting to see that Lebanon's well-being was seen as an important information at the top of the story, in which the "present crisis" is equated with the Israel invasion. Also, the story makes a point to mention that criticism of Israel was omitted from the letter. The strong use of language - denouncing the Israeli drive into Lebanon - is also rare in today's coverage of Israel; so is the quote that refers to the "blind allegiance" to Israel. The selection of two quotes is also remarkable: "that country now feels it has a free hand to use American firepower with total disregard for U.S. law and total disregard for America's best interests in the Middle East;" and, "James Abourezk, D-S.D ... said the House resolution had a relatively small number of cosponsors because "the Israeli lobby has intimidated most politicians 
- it's what I call political terrorism."” The piece would be rare in today's mainstream American journalism; even more significant was the fact that the U.S. Congress took such a stand. Even in the unlikely event that it would take such a position today, the media may not necessarily report it so bluntly. A comprehensive analysis of the war and its aftermath from Tel Aviv appeared on September 15, 1982, titled "Gemayel Death Could be Third Israeli Setback in Lebanon." It was rich in background and context: "Israel hoped the PLO's defeat would break its hold on the people of the occupied West Bank of the Jordan River and Gaza Strip, and allow a Palestinian leadership not linked to the PLO to come forward and accept the limited self-rule Israel is offering for the territories." $\$ 6$ However, half way through the 653-word story, it begins to lean toward the Israeli narrative. First, it claims that "the immediate result of Gemayel's murder was that Israeli troops were ordered into hostile west Beirut," - which -without clarification or evidence - makes it sound as if Israel went into west Beirut reluctantly and did not in fact invade it. The following paragraph makes a value judgment: "That could mean more casualties for an Israel that already is emotionally wrenched by the loss of 340 men so far in the 101-day-old invasion. At the same time, however, the push into west Beirut may allow the Israelis to root out any remaining Palestinian guerrillas and Moslem leftist militias there."

d) Omission: On the first day of the war, the AP did not say that there had not yet been any claim of responsibility for the Israeli ambassador's shooting in London or that it was unclear who was behind it. Had it done so, it would have at 
least raised some doubt in the mind of the reader about the Israeli assertion. It could have explained - preferably in the lead where the Israeli claim was cited that it was yet unclear who carried out the attack. The lead of one of the first stories read: "Waves of Israeli jets thundered over southern Beirut today, rocketing and bombing the capital's Palestinian strongholds in swift retaliation for the attempted assassination of the Israeli ambassador to Britain.” The Israeli claim that it was in retaliation came only in the penultimate paragraph of the 11paragraph story that appeared in the Spokane Chronicle. In other words, the lead took the Israeli assertion at face-value that it was in retaliation for the shooting in London and presented it as a fact. Or it was the writer's assumption that it was. Also missing from the story and other stories surveyed was the fact that none of the targets of Israeli bombardments belonged to Abu Nidal's group (which did not even have an office or representative in Lebanon). Whether it was sloppiness on the part of the writer or editor who were under extreme pressure to move the urgent stories on the wire, the story on the day of the eruption of the 1982 war was poor in context, skepticism, background, leading to a misleading narrative that would continue for days and weeks to come. On June 8, four days after the war broke out, when it was officially established who was behind the attack on Argov, AP copy identified Argov's attackers only as "Arab gunmen," without spelling out that they were not the PLO or that they were in fact enemies of the PLO. An 811-word Tel Aviv-dated story on June 9 about Prime Minister Menachem Begin and Defense Minister Ariel Sharon, titled, "Israel's Two War 
Leaders Unlikely Partners" omitted a crucial information about Begin - that he was the leader of the Irgun militia that carried out deadly attacks on the Palestinian population, including the massacre of 112 civilians in the village of Deir Yassin on April 9, 1948. However, the story was filled with quotations from Begin denouncing the PLO as a "terrorist" organization. "To Begin there is a direct line between the Nazi Holocaust and the Palestinian war on Israel. In a speech to Parliament on the third day of the war, Begin ranged through history from the days of King Solomon to the anarchist terrorism at the turn of the century and wound up calling the Palestine Liberation Organization the most despicable outfit since the Nazis. 'We will defend our children,' said Begin, his voice quavering with anger and sadness. And if the hand of a two-legged animal is raised against them, it will be cut off." Note the word, "sadness." It is unclear what the writer was trying to convey here. Yet in another paragraph, in reference to Sharon, the story identifies Arab actions against Israel as terrorism while Israel responds to them: "As a young major, Sharon was put in charge of running a secret army unit that carried out reprisals for Arab terrorist attacks."

e) Language: AP copy generally referred to Israeli bombardment of Lebanon as hitting PLO "targets" or "strongholds." The use of words such as "targets" or "strongholds" belonging to the PLO gave the misleading impression that these were military bases and encampment in the middle of nowhere. Few stories mention that these "strongholds" were in fact residential neighborhoods of highrise buildings and narrow streets, and refugee camps - hence the big number of 
civilian casualties. An August 10 story, however, puts this fact in context: "The guerrillas of the PLO are the target of the two-month-old Israeli invasion, and they are holding out among the people of west Beirut." ${ }^{87}$ Without making any value-judgment, the story describes the actual situation on the ground in Beirut. Also, in a June 22 story roundup of war developments, the AP mentions civilian targets, saying the Israeli bombardments of Beirut followed "a day of incessant artillery and gunboat shelling of Palestinian targets and residential neighborhoods in west Beirut Monday." ${ }^{88}$ By June 22, the AP had added another context in addition to Israel's justification: "The invasion was launched June 6 with the stated goal of driving the Palestinian guerrillas 25 miles back from Israel's border, but the invasion army drove all the way to Beirut, 50 miles north of the border, and appeared intent on destroying the guerrillas' Beirut nerve center. The new Beirut bombardments followed a day of incessant artillery and gunboat shelling of Palestinian targets and residential neighborhoods in west Beirut Monday." 89 The reference to "Israel's stated goal" appeared to be a boilerplate during the war. AP's coverage of the 1982 war, like most other mainstream media, shifted across Hallin's three spheres with various degrees and at different stages of the conflict. At the very beginning, most mainstream Western media, including the AP, generally worked from the more traditional sphere of legitimate controversy, even though the two antagonistic sides were not represented equally. They moved to the deviance sphere by some news outlets when civilian casualties mounted and destruction of Lebanon became widespread. AP stories that editors in New York put 
together perhaps continued to be in the "sphere of legitimate controversy," while human interest sidebars filed from Lebanon were indeed down in the middle - while exposing the suffering of civilians, they did not necessarily condemn Israeli behavior or exclude Israeli justifications for their actions. In studying media war coverage, according to Simon Cottle, we need to "consider their generalities and specifics, as well as informing theoretical frameworks and methodologies in order to reach a deeper understanding of the various dimensions of the various dynamics, complexities and contingencies of media production and performance in national and international mediatized conflicts today." $"$ It does not mean "media representations are beyond critical analysis or evaluation, or that we cannot develop the critical benchmarks to systematically and incisively analyze forms of media output, but it is to say that notions of 'bias,' 'distortions' or even 'propaganda' cannot do all the hard work for us. ${ }^{91}$ Conflicts are simple to define when they are initially a struggle between opposing interests or outlook, said Cottle, but they become less so when they are "theorized as latent or manifest, structurally determined or purposefully enacted, objectively real or subjectively perceived, raising philosophical issues about origins, determination, social construction and the role of intentionality and agency in their enactment." ${ }^{.92}$

Despite a few instances where context and background were missing, the AP coverage of the 1982 war enjoyed a great deal of discipline in being honest in reporting straight news, writing analysis and features, especially in reflecting the human suffering of civilians under bombardment (I was able to access only two of 
those stories, but from my recollection, there were a great number of them). The human element factor was prominent in explaining the plight of victims, such as Terry Anderson's powerful account of the dying child in hospital as Dr. Amal Shamaa tried to save him from wounds he suffered from an Israeli phosphorous attack; or Earleen Fisher's "Death of a Button Seller" that took the reader to the very spot the woman was cut down by an Israeli shell with her vivid, detached, yet moving writing. Fisher made no judgment in her story, she did not accuse anyone, only reconstructed the events, avoiding loaded or emotional language. As did Anderson, even though he was so overwhelmed with emotion, as Dr. Amal Shamaa (Appendix A, 23) told me 30 years later, that "he ran out of the hospital and I didn't see him again." Their credibility and authenticity were of high standard: Anderson was a primary source watching the child die, with additional medical information from the doctor who treated the boy. Fisher painstakingly reconstructed every detail of the incident by talking to witnesses and the button seller's family. The information Anderson and Fisher provided were not just about those two single incidents, but the effects of the siege and bombardment; they gave the reader glimpses of a day in the life of an ordinary civilian during the war. There was no need for "balance" to give opposing views. There was no need for a comment from the Israeli army, a denial perhaps that they used phosphorous bombs against civilians, or that the people killed in the line of bread were collateral damage or human shields. The balance would only have made the story hypocritical, not objective; it would not have been informative. An analysis about the controversial and banned use of phosphorous bombs or shelling civilians 
would have warranted opposing views. They AP did that too. - as in the example of the Sidon school where refugees had taken shelter when Israeli planes bombed it. Fisher, as a primary source, saw a T-54 tank that belonged to the PLO outside the school. Whether the PLO had used the refugees as a human shield is unclear, but Fisher's job was to report it without making an absolute judgment. The three stories stand out because of the reporters' discipline in reporting them, as were scores of others during the 1982 invasion.

Fisher, an American, did not speak Arabic, but her deep knowledge of the Middle East, its long complexed history, politics, people and culture (she lived in Lebanon and bought buttons from the shop where the woman in her story worked), made her an authority on the region - and beyond. Everyone in the office considered her a walking encyclopedia. The most important component of the AP operation in Beirut in the 1980s was its strive for accuracy to the extent that I was mortified when I went on a reporting assignment and worried if I missed any detail. Fisher, who handled most of the editing in Beirut, was merciless - and unforgiving - for making sure all the details were there.

\section{Endnotes}

\footnotetext{
1 Associated Press, published in Spokane Chronicle, June 4, 1982 - http://news.google.com/newspapers?

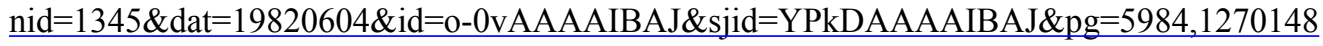

2 ibid.

${ }^{3}$ ibid.

${ }^{4}$ ibid.
} 
${ }^{5}$ Robert Fisk, Pity the Nation: The Abduction of Lebanon. (UK: Andre Deutsch, 1990).

${ }^{6}$ Noam Chomsky, Fateful Triangle: Israel, the United States, and the Palestinians (Montreal: Black Rose Books Ltd., 1984).

7 Edward Alexander, "NBC'S War in Lebanon: The Distorting Mirror," 1983, http://afsi.org/pamphlets/ NBC war in lebanon alexander[1].pdf; See also: John Corry, New York Times, "TV: View of NBC Coverage of Lebanon Invasion," Feb. 18, 1984. http://www.nytimes.com/1984/02/18/movies/tv-view-of-nbccoverage-of-lebanon-invasion.html

${ }^{8}$ See Chapter One for Hallin's theory of compartmentalized objectivity. Daniel C. Hallin, The "Uncensored War": The Media and Vietnam (California: University of California Press, 1989) pp. 116-117.

${ }^{9}$ Michael Schudson, "What's unusual about covering politics as usual" in Barbie Zelizer and Stuart Allan (ed.), Journalism After September 11 (New York: Routledge, 2002).

10 See Chapter One for Gans' theory. Herbert J. Gans, Deciding What's News: A Study of CBS Evening News, NBC Nightly News, Newsweek, and Time (Chicago: Northwestern University Press, 1979) pp. 94-96.

${ }^{11}$ Fisher used the byline Earleen F. Tatro during the 1982 invasion.

${ }^{12}$ Chomsky, op cit, p. 220. See also Edward Said, "Question of Palestine," 1979, quoting from Al Hamishmar, May 10, 1978. [Publisher: Vintage; Vintage Bks Ed., Apr. 1992 edition (April 7, 1992).

${ }^{13}$ A school bus attack by PFLP-GC in the "frontline settlement" of Avivim - about one kilometer from the Blue Line with Lebanon - on May 22, 1970, killed 12 people, including nine children. Israel shelled four Lebanese border villages, killing 20 civilians and forcing thousands of people in the southern Lebanon to flee north. See also Chomsky, op cit.

${ }^{14}$ Said, op cit.

15 ibid.

16 ibid.

17 Chomsky, op cit, p.181.

${ }^{18}$ Chomsky, op cit, p. 220

${ }^{19}$ Chomsky, op cit, p. 182.

20 ibid.

${ }^{21}$ Chomsky, op cit, p. 220.

${ }^{22}$ Ze'ev Schiff and Ehud Ya'ari, Israel's Lebanon War ( New York: Simon \& Schuster, 1984).

${ }^{23}$ Sabri al-Banna, also known as Abu Nidal, had even vowed to kill Arafat for expressing willingness to make peace with Israel. The PLO had sentenced him to death for crimes against the Palestinian people.

24 On 17, July 1981, Israeli bombs and rockets killed about 300 civilians in Lebanon. The PLO retaliated by attacking northern Israel. The civilian casualties in Lebanon provoked international outrage, prompting the US to suspend scheduled shipment of F16 fighter jets to Israel. It also led to a U.S.-brokered cease-fire between Israel, the PLO and Syria. See also, CNN, “Timeline: Decades of conflict in Lebanon, Israel," July 14, 2006 -http://edition.cnn.com/2006/WORLD/meast/07/14/israel.lebanon.timeline/ 
25 Chomsky, op cit p. 192.

${ }^{26}$ Schiff and Ya'ari, op cit.

27 Ze'ev Schiff cited by Chomsky, op cit

${ }^{28}$ Chomsky, op cit p. 195.

${ }^{29}$ Fisk, op cit.

30 Alexander, op cit.

${ }^{31}$ Internal AP memos provided by Stephen K. Hindy. For full transcript see Appendix C.

${ }^{32}$ Chomsky, op cit. p. 218.

${ }^{33}$ The Commodore Hotel was the base of most of the international press during the invasion.

${ }^{34}$ As an example, see: AP archive, "EDITOR'S NOTE - THE FOLLOWING COPY WAS SUBMITTED TO THE ISRAELI," June 16,1985. http://www.apnewsarchive.com/1985/EDITOR-S-NOTE-The-following-copy-was-submitted-to-the-Israeli-military-censor-who-ordered-a-significant-deletions-/id-304c7c3eb2e6fbca03d6cb3e49ec6731

${ }^{35}$ Chomsky op cit.

${ }^{36}$ Henry Kamm, New York Times, "Israelis Shrugs off any PLO Gains," July 17, 1982. http://www.nytimes.com/1982/07/17/world/israelis-shrug-off-any-plo-gains.html

${ }^{37}$ See for example these series of ABC reports on the 1982 invasion and its immediate aftermath. Note the difference in critical reporting between reports originating from Lebanon and those from Jerusalem: 1. Israel: Invasions of Lebanon, part 1. https://www.youtube.com/watch?

$\mathrm{v}=\mathrm{GN} 3 \mathrm{~L} 6 \mathrm{Ci}-9 \mathrm{uA} \&$ list=PL2CBE4F0603BA9FE5. 2. Israel vs. the PLO -The Invasion of Lebanon 1982 Part 2. https://www.youtube.com/watch?v=ykNSpx1w91A. 3. Israel vs. the PLO -The Invasion of Lebanon 1982 Part 3. https://www.youtube.com/watch?v=ynyNmnL-FGE. 4. Israel vs. the PLO -The Invasion of Lebanon 1982 Part 4. https://www.youtube.com/watch?v=Q45P510lbbk. 5. Israel vs. the PLO -The Invasion of Lebanon 1982 Part 5. https://www.youtube.com/watch?v=1sd7bRcFgW0

38 Arthur Unger, The Christian Science Monitor, “Television's 'battle of Lebanon'- distortions?” Aug. 12, 1982. http://www.csmonitor.com/1982/0812/081253.html

39 ibid.

40 Following an angry telephone call President Reagan made to Prime Minister Begin on August 14, 1982 instructing a ceasefire, Begin wrote a defiant letter to Reagan saying: "In a war whose purpose is to annihilate the leader of the terrorists in West Beirut, I feel as though I have sent an army to Berlin to wipe out Hitler in the bunker." See, Sandra Mackey, Lebanon: A House Divided (New York: Norton \& Company, 2006) pp. 177-78.

${ }^{41}$ Segment begins at minutes 5.39: Israel Vs. The PLO -The Invasion of Lebanon 1982 Part 3. https:// www.youtube.com/watch?v=ynyNmnL-FGE 
42 ibid.

43 John Corry, New York Times, “TV: View of NBC Coverage of Lebanon Invasion,” Feb. 18, 1984. http:// www.nytimes.com/1984/02/18/movies/tv-view-of-nbc-coverage-of-lebanon-invasion.html

44 ibid.

45 ibid.

46 ibid.

${ }^{47}$ According to its Website, ADL was founded in 1913 "to stop the defamation of the Jewish people and to secure justice and fair treatment to all." Now America's premier civil rights/human relations agency, ADL fights anti-Semitism and all forms of bigotry, defends democratic ideals and protects civil rights for all.

${ }^{48}$ Chomsky, op cit, p. 284.

49 ibid.

50 ibid

${ }^{51}$ For example, Edward Alexander, "NBC's War in Lebanon: The Distorting Mirror" - http://afsi.org/pamphlets/NBC_war_in_lebanon_alexander[1].pdf

52 University of California Press, "We Shall Return: Women of Palestine. by Ingela Bendt," 1984.

: http://www.jstor.org/discover/10.2307/2536903?

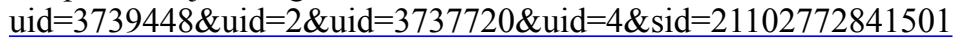

53 Note in his June 25, 1982 dispatch, ABC's Richard Threlkeld hinted at this disillusionment of Israel: "As for Israel, it has never been more secure and never so quite alone in the world. It has confounded its enemies and it has commanded fear and respect, but it's not the Israel its first Prime Minister Ben-Gurion always imagined it would be, that Israel, that light onto the nations." "Israel vs. The PLO -The Invasion of Lebanon 1982 Part.3": https://www.youtube.com/watch?v=ynyNmnL-FGE. Recall, however, Ben-Gurion's comments on targeting civilian casualties.

${ }^{54}$ Noam Chomsky. Personal interview. Cambridge, MA, May 2009.

55 Daniel Pipes, “The Media and the Middle East,” June 1984 — http://www.danielpipes.org/166/the-media-and-the-middle-east

56 ibid.

${ }^{57}$ Chomsky, op cit.

58 Fisk, op cit p. 285.

59 Peggy Thomson, Counterpunch, "20 Years After Sabra and Shatila: the Forgotten Massacres," Sept. 18, 2002. http://www.counterpunch.org/2002/09/18/sabra-and-shatila-the-forgotten-massacres/ 
${ }^{60}$ AP's Eearleen Fisher and I had the grim job of compiling the casualty figures - the civilian dead - based on tallies from the police (that our police stringer Bahjat Jaber provided), hospitals, local and international relief organizations and the government. One of my beats in the summer of ' 82 was to make daily visit to the offices of ICRC, a few blocks from the AP bureau, for an update on the latest casualty figures, number of people fleeing the fighting and the general condition of the humanitarian relief mission. I also made daily tours of Beirut's major hospitals where tearful and frustrated relatives searched hospitals looking for loved ones missing following Israeli shelling. I also visited schools and unoccupied buildings where the fleeing population had taken refuge.

${ }^{61}$ George E. Bisharat, USA Today, “Did Israel really need to savage the beauty of Beirut?” Aug. 1, 2006 : http://usatoday30.usatoday.com/news/opinion/editorials/2006-08-01-beirut-beauty-edit_x.htm ). See also Fisk, op cit. p. 418: "According to the most detailed figures, almost 17,825 between June 4 June and the end of September 1982 alone - were the result of Israeli action."

${ }^{62}$ Chomsky, op cit. p. 221.

63 ibid, p. 299.

64 Thomas Friedman, From Beirut to Jerusalem (London: Collins, 1990), p. 157. See also: http:// www.photius.com/countries/lebanon/national_security/lebanon_national_security_the_siege_of_beirut.html

65 "Israel bombs Beirut to avenge shooting," Spokane Chronicle, June 4, 1982. http://news.google.com/ newspapers? nid=1345\&dat=19820604\&id=0-0vAAAAIBAJ\&sjid=YPkDAAAAIBAJ\&pg $=5984,1270148$

66 Michael Goldsmith, AP archives, June 22, 1982.

${ }^{67}$ Farouk Nassar, AP archives, June 23, 1982. Also, AP published in New York Times, PLO Troops Begin Pullout in Beirut, Aug. 22, 1982. http://www.nytimes.com/1982/08/22/world/plo-troops-begin-pullout-inbeirut-french-enter-city.html

68 Fisk, op cit p. 285.

69 Earleen F. Tatro, The Daily Register, Death of Lebanese woman recounted, Aug. 10, 1982. http:// 209.212.22.88/Data/RBR/1980-1989/1982/1982.08.10.pdf

70 Marcus Eliason, AP archives, “Israel's Two War Leaders Unlikely Partners,” June 9, 1982.

${ }^{71}$ AP archives, July 25, 1982.

72 Charles J. Hanley, AP archives, “Lebanon Crisis Won't End With PLO Pullout,” Aug. 14, 1982.

${ }^{73}$ Marcus Eliason, AP archives, "Gemayel Death Could be Third Israeli Setback in Lebanon," Sept. 15, 1982.

${ }^{74}$ Larry Thorson, AP archives, "Defense minister with big ideas for Israel," Sept. 22, 1982.

${ }^{75}$ Marcus Eliason, AP archives, Sept. 25, 1982

76 AP archives, “Colonel Who Resigned Over War Speaks for First Time,” Sept. 1982.

77 AP archives, June 8, 1982. 
78 Barton Reppert, AP archives, "Lines Of Support, Opposition To Israeli Action Forming In Congress," June 11, 1982.

79 Nicolas B. Tatro, AP archives, “Syrians Parade Israeli Tank Through Damascus,” June 11, 1982.

80 David Minthorn, AP archives, “Brezhnev Blames U.S. for Massacre, Urges U.N. Action. Sept. 20, 1982.

81 George Gedda, AP archives, July 30, 1982.

82 According to Lebanese army figures cited by the New York Times, 1.4 Israeli violations of Lebanese territory were recorded every day from 1968-74, with 17 a day in 1975, when the tally ended. By October 1977 , it was estimated that the total number of refugees from the south had reached 300,000. Noam Chomsky, Fateful Triangle: Israel, the United States, and the Palestinians (Montreal: Black Rose Books Ltd., 1984).

${ }^{83}$ Undated AP story of June 8, 1982 accessed through LexusNexus.

${ }^{84}$ Michael Goldsmith, AP archives, June 22, 1982.

85 Barton Reppert, AP archives, "Lines Of Support, Opposition To Israeli Action Forming In Congress," June 11, 1982.

${ }^{86}$ Marcus Eliason, AP archives, “Gemayel Death Could be Third Israeli Setback in Lebanon,” Sept. 15, 1982.

${ }^{87}$ Earleen F. Tatro, The Daily Register, Death of Lebanese woman recounted, Aug. 10, 1982. http:// 209.212.22.88/Data/RBR/1980-1989/1982/1982.08.10.pdf

${ }^{88}$ Michael Goldsmith, AP archives, June 22, 1982.

89 ibid.

90 Simon Cottle, Mediatized Media: Development in Media and Conflict Studies (UK: Open University Press, 2006).

91 ibid.

92 ibid. 


\section{Chapter 3: Competing Narratives - 1982-2000}

A day after the multinational peacekeepers left Lebanon on Sept. 11, 1982, Israeli Defense Minister Ariel Sharon, without evidence, charged that " 2,000 terrorists" remained inside the Palestinian refugee camps. ${ }^{1}$ Under the U.S.-brokered truce accord that ended the 1982 invasion, the Americans had guaranteed the security of Palestinian civilians in the refugee camps. Less than two days after Bashir Gemayel was assassinated on Tuesday Sept. 14, the Israeli army invaded West Beirut despite a pledge in the ceasefire agreement that it would not do so. ${ }^{2}$ It established control of the periphery of Sabra and Shatilla refugee camps in Beirut and allowed in Phalange militiamen. For more than 40 hours militiamen slaughtered unarmed civilians as Israeli officers and soldiers around the camps watched with binoculars, and illuminated the night with flares so the militiamen could go about their killing. ${ }^{3}$ They prevented Palestinian camps' residents from escaping. ${ }^{4}$ On the morning of Saturday Sept. 16, international journalists and diplomats arrived in the camps to discover hundreds of scattered corpses. "The bodies of families, men, women and children, were in the cinderblock shacks that had been their homes. On the street, bodies of men lay in a jumble as if they had been herded together and gunned down," the AP reported. ${ }^{5}$

This chapter takes four major topics - the Palestinian massacre, U.S. involvement in Lebanon, Israel's occupation that resulted in the birth of Hezbollah (1982 to 1985), and the 1996 Israel-Hezbollah war to extrapolate the changes in AP 
coverage in a span of more than a decade, and examine why and how AP's impartiality diminished over the years. It also features interviews with more than 25 former and current AP journalists to establish some of the factors that led to these changes. It also relies extensively on first-person narratives, and my personal experiences.

News of the massacre struck like lightening throughout the world, prompting the MNF to return to Lebanon. The invasion and the massacre - catalyst for a gradual change in media coverage - earned Israel worldwide criticism. The international media described the slaughter of the refugees as revenge for Gemayel's death, even though the plan for going into the camps was taken long before the assassination. Two days before he was killed, Gemayel agreed with Sharon to "mop up" the camps. ${ }^{6}$ When news of the massacre reached the outside world, the Phalange denied involvement. Israel denied any knowledge. But after the media reported the Israeli presence around the camps, Israel denied responsibility for it. ${ }^{7}$ Israeli Chief of Staff Rafael Eitan blamed Phalangists and indirectly the Lebanese army and the Americans. ${ }^{8}$ However, at a Cabinet meeting in Jerusalem, Sharon, Eitan and General Amir Drori, the senior Israeli commander in Lebanon, acknowledged that the Israeli Defense Forces (IDF) had coordinated the Phalangists' storming of the camps. 9 "Initially, the Israelis were saying 'oh we don't know anything about that.' And then we went to the observation post that the Israelis had set up around the camps, and you could see from these posts right into the camps.... It was pretty easy to refute their claims that they didn't know what was happening," Stephen K. Hindy 
(Appendix A, 10), who was in charge of the AP operation after the bureau chief left on vacation, says in an interview for this thesis. The presence of Israeli and Israelbased journalists in the camps, says Hindy, perhaps allowed the coverage to reflect what had actually happened without giving credence to IDF denials.

When the Israeli government, under pubic pressure, established the Kahan Commission to investigate the massacre, Tatro asked me to line up survivors so we could have immediate reactions when the results came out. One survivor was Ektefa Shallah, whose husband was killed on the first afternoon of the massacre. Unaware of the significance of what she was revealing, she told me that Israeli soldiers had accompanied the militiamen during the massacre. The soldiers spoke to each other in Hebrew, a language she learned as a child before she fled her home in the Tel Aviv suburb of Jaffa during the1948 war that led to the creation of the state of Israel. Her daughter, Jamila, also talked to an Israeli soldier. So did their neighbor, Amneh Khalifa. The revelation of an Israeli presence in the camps during the massacre was a huge scoop. I messaged the phonetic pronunciation of what Shallah said were the Israeli soldiers' comments in Hebrew to AP's Tel Aviv office which confirmed they were indeed Hebrew words. The story, published on December 22, $1982^{10}$ made a big splash in a huge number of newspapers around the world. The AP promoted it as it did every exclusive story and picked it as the story of the month - a sharp contrast to how the AP was to cover the 2006 war as we shall see in Chapter 5 .

While not finding any Israeli directly responsible, the Kahan Commission concluded on February 8, 1983 that Sharon bore "personal responsibility" for "not 
ordering appropriate measures for preventing or reducing the danger of massacre" before sending the Phalangists into the camps. ${ }^{11}$ It suggested that Prime Minister Menachem Begin remove him from office. Sharon resigned as defense minister but retained his cabinet position as minister without portfolio, and over the next 16 years held four more ministerial posts before becoming prime minister in February 2001.

The stain on Israel stuck for a while, and the general U.S. media were "able to say things about what Israel did that they were not able to say before and after that," says former $\mathrm{ABC}$ correspondent Charles Glass (Appendix A, 7) in an interview. "Something big happened during the massacre of Sabra and Shatilla which opened a space for more critical reporting of what Israel was doing in Lebanon. ... That window was opened for almost a year I would say and then closed again when Sabra and Shatilla was forgotten." American media narratives had long been perceived as inducing apathy toward Arab suffering. "The "original sin," according to Chomsky, was the adoption of certain vocabularies as points of reference, such as "terrorists," that encompass "the whole of the Palestinian people." When Palestinians are "terrorists," they can "be bombed, shelled, expelled, denied their humanity."12

Inside Israel, criticisms were harsher than outside. Some 400,000 Israelis out of a population of 4 million - demonstrated in Tel Aviv on Sept. 25, 1982 to protest the Beirut massacre, the largest anti-government demonstration Israel had ever seen. ${ }^{13}$ Peace activist Naomi Kies referred to television showing "a little boy coming out of the rubble with his hands up," conjuring up memories of "a Holocaust picture we wanted to forget." ${ }^{14}$ Such strong commentaries were difficult to take for Israel, 
which is fixated on its world image. "Israelis are very sensitive about their image abroad, especially in view of the fact that whatever happened in Lebanon is being felt by Jewish communities abroad, with a considerable rise in anti-Semitism," Meron Medzini, a former director of the Government's information office, told the New York Times. ${ }^{15}$

Even before the massacre, an AP story of July $25,1982,{ }^{16}$ addressed the issue. "Israel's image in the world press as a result of the Israeli invasion of Lebanon could spark a new wave of anti-Semitism, a group of professors and reserve army officers warned Sunday." Begin called for a swift correction of the image.

The Hasbara Project, launched in 1983 in its present form, was to ensure good press in U.S. media. The aggressive public relations campaign to rebrand Israel's damaged image would in the coming years transform into one of the world's most sophisticated. It would train Israeli press officers in nine Israeli consulates in the U.S. in communications and public relations skills, monitor media outlets and develop relationships with journalists. ${ }^{17}$ The advocacy's principle strategy was to "delegitimize" coverage deemed unfavorable to Israel, and a common strategy was to slap the anti-Semitic label. 18 "As one of these press officers said in the 1980s, he had breakfast, lunch and dinner with journalists, and that a typical day would involve conversations with producers at leading news and TV talk shows about the content of the program. He described it as in fact, 'a joint formulation of ideas."'19 The American Israeli Public Affairs Committee (AIPAC), would become the most influential U.S. organization to reiterate the official Israeli line and organize 
grassroots opposition to unfavorable coverage. A host of media watchdog groups would monitor and pressure journalists and their editors to make sure coverage is proIsrael. The most prominent is the Committee for Accuracy in Middle East Reporting in America, or CAMERA ${ }^{20}$, an American pro-Israeli media-monitoring organization. In a short time, Israel's public relations drive succeeded in overhauling American media coverage of the Middle East as we shall see later in this chapter and the following chapters.

This is not to say that Israel's propaganda machine was inactive before the invasion. Immediately after Israel stormed West Beirut in September, soldiers made unannounced visits to the AP office and the Commodore Hotel where the international press stayed. "They kind of let their point be known. They were schmoozing and saying 'did you notice this, did you notice that? This is what our policy is' ... So they started to politic ${ }^{21}$ [sic] the press in a very American sort of way," says Tatro. According to Labelle (Appendix A, 13):

Most Americans view the history of the Arab-Israeli conflict through an Israeli prism. Jewish groups in the U.S. also push the Israeli version of events and are quick to criticize news stories with which they disagree. So American reporters in the Middle East, faced with a skewed view of history by their readers, are likely to be cautious about reporting events involving Israel or its troops because their stories are likely to be challenged if they get something wrong.

Fisher, who moved to Israel from Lebanon a year after the invasion, remembers some of the intimidations: 
It was a constant, 'the Beirut press was in the PLO camp' ... There was no concept of impartial or neutral reporter. It's like, 'everybody's for us or against us.' If you were in Beirut, you are for the Palestinians and you are against the Israelis. It was terribly simplistic. It was like, 'we know you're not to be trusted,' or 'you're not one of us.'

In early 2000s, when the PR had reached its peak, a pro-Israel lobby asked AP's Jerusalem office ${ }^{22}$ to provide a breakdown of the staffers' religions and ethnicities - Jews, Christians and Palestinians. ${ }^{23}$ The Israel-Palestinian story was one of the closest watched in the world; "the least thing would trigger floods of complaints - from readers, officials, interest groups," says Susan Sevareid (Appendix A, 24), a former AP reporter in the Middle East, whom I interviewed. One of Jerusalem bureau's main tasks was to make sure it did not trigger an avalanche of complaints emailed or telephoned to top editors. It was not so much keeping damaging information out of the news, says Sevareid, but avoiding "silly factual mistakes that would be used to discredit everything written." Effort was made to "properly attribute anything that could be deemed judgmental or favorable to one side, and to take care to avoid inflammatory word choices." Another former AP reporter who asked not to be identified and will be referred to throughout the thesis as Interviewee A (Appendix A, 28), adds: "Everybody was extra careful of their copy because they knew how heavily it was going to be scrutinized by Israeli/Jewish lobbyist groups back in the States."

"My experience was that every time that you wrote a story about Israel - there is a group called CAMERA - you would just get emails from them, from groups like that; they would write it up on their website and complain about your story. They 
went to bosses, tried to bring pressure on them as well... If nothing else, they take time and you have to deal with them politely. It is a barrage," says the journalist. Israel's PR drive, central to this thesis, will resurface throughout the thesis and will be explored as it becomes more aggressive over the years.

In the wake of the camps' massacre, U.S. Marines, French paratroopers and Italian forces returned to Lebanon, landing in Beirut again on September 24, 1982. A small contingent of British troops joined them later. With the U.S. Marines in Lebanon, AP coverage became heavily focused on them. The 1,800 force deployed at the airport and the perimeter to its immediate south in Khalde. They Marines patrolled the Shia Muslim slums of Beirut's southern suburbs. The French patrolled the commercial center of West Beirut, while the Italian area of operation encompassed Shatilla, Bourj el-Barajneh and the adjacent Shia districts. The Americans also maintained Sixth Fleet aircraft offshore. Meanwhile, the Israelis withdrew only 10 kilometers from West Beirut, going back to the frontlines they held during the siege of Beirut. The Syrian army controlled the coastline, about 30 kilometers north of Beirut; along the summit of Mount Lebanon to Sofar on the Beirut-Damascus highway, and east across the Bekaa Valley. The Chouf Mountain area, occupied by Druze and Maronite militias (the latter brought up by the Israelis), were in a state of semi-war. Further south, the Israeli occupation forces were fighting an armed Lebanese resistance that was growing more deadly by the day. Also, there were up to 10,000 Palestinian guerrillas in the eastern Bekaa and in and around the northern Lebanese city of Tripoli. The presence of several hundred Iranian 
Revolutionary Guards in Bekaa's ancient city of Baalbek was with the acquiescence of the Syrians. Amal was the most prominent of Shia groups, although a more religious faction (Islamic Amal) that had fought the Israelis drew its inspiration from Iran. $^{24}$

It was against this backdrop that the MNF operated. The months following the deployment saw increasing conflict between Israel and the U.S. at the rhetorical level and even occasional direct military confrontation. ${ }^{25}$ The U.S. administration intermittently reported to the U.S. Congress on Israel's use of aircraft, armor, artillery, and other equipment for offensive missions across the border in Lebanon. At first the Muslim Lebanese and Palestinian population perceived the Americans as protecting them from the Israelis and the Phalange Christians. What endeared them most was a publicized incident on Feb. 25, 1983 when a Marine captain drew his pistol to block three Israeli tanks that had penetrated his position, and jumped onto one of them. ${ }^{26}$ The incident was played up with great relish by the local media depicting the Marine as a hero. The Marines gave the media, including the Lebanese, regular access without coming across as propagandists; they did not impose censorship, nor did they pressure the media to echo their line.

The Reagan administration, however, soon began to take the side of the Phalange-dominated government against Druze and Shia factions. American troops gradually came to be seen as enemies by these factions. Mistrust turned to outright belligerence once American forces used their firepower to shell Shia and Druze 
positions in the mountains surrounding Beirut. It took 17 months for the mighty Western force to collapse with irreparable consequences. ${ }^{27}$

The AP covered every event pertaining to the Marines. The coverage echoed Daniel Hallin's description of journalistic routines of covering wars, i.e. daily "human interest vignettes about the troops, occasional 'light stories' which have no significant value as information of the war."28 One AP Beirut routine was to telephone the Marine base every morning to ask about their day's activities for a fresh angle of the early morning cycle. On quiet days, mundane comments such as, "I washed my armpit" or "brushed my teeth," were duly inserted in the main story.

Daniel Pipes described media's reporting of the Marines distorted:

Problems arise when the U.S. angle comes to dominate; Americans find it more interesting to read about themselves than about foreigners. It is fearfully easy for them to lose track of the larger question in favor of the U.S. role. Journalists are the first to fall into this trap." 29

The problem with that, he said, was that international issues become domesticated. Pipes' analysis, however, did not apply to the AP. In the 1980s, while covering the Marines extensively, the AP did not ignore other news in Lebanon. Its reporting was broad and perhaps one of the most comprehensive and hands on of any media organization. It investigated almost every significant event, rumor or massacre, and did not rely simply on military or government press releases, or radio reports. Most of the time telephone lines were non-existent, which meant journalists had to make trips to the Marines or other politicians and spokespeople themselves, hold face-to-face meetings with them, interact and ultimately get much more than a simple 
quote. Unlike the 2006 or Iraq wars, AP reporters had more than brief meetings with civilians. Field reporting was AP's strength. While a reporter was with the Marines, another was reporting the militia war, another covering inter-PLO battles in northern Lebanon.

When rumors started circulating that a few hundred Iranian Revolutionary Guards, who had slipped into Lebanon during the confusion of the invasion, had set up headquarters in the ancient city of Baalbek, I went to investigate. A revolutionary guard admitted that they were in Lebanon for "propaganda reasons" and "to guide the people to export Iran's Islamic revolution." 30 The Israeli invasion had given the Iranians an opportunity to export their revolution under the pretext of defending Shias and other "oppressed" Muslims against the Israelis and the Phalange. Ironically, the Israelis helped seal Iran's influence in Lebanon for years to come. The Iranians would train men of the Islamic Amal, the group that splintered from the more "moderate" mainstream Amal and was most likely behind the bombings against U.S. and Western targets in the months ahead. The Islamic Amal would in just a few years transform into Hezbollah, the group behind the campaign of kidnappings and suicide bombings, and ultimately driving the Israeli occupation out of Lebanon almost 20 years later. ${ }^{31}$

Their first target was the U.S. Embassy in Beirut on April 18, 1983 when a suicide bomber drove his car into the building, killing 63 people, ${ }^{32}$ including 17 Americans - eight of whom worked for the Central Intelligence Agency, including its top Middle East analyst and Near East director, Robert Ames and the agency's entire Middle East contingent. Thirty-two Lebanese employees and 14 visitors and 
passersby were also killed. It was the deadliest attack on a U.S. diplomatic mission until then and was seen to mark the start of anti-U.S. attacks by Islamist groups. The loss of human intelligence would cost the United States dearly in the months and years to come. However, Not only American policy did not change after the attack, U.S. ties with the Gemayel government strengthened. It came 34 days after Reagan ordered the Americans to fire on anti-government militia positions, effectively becoming a party to the civil war. On Sept. 19, 1983, U.S. navy warships for the first time opened fire in support of the Lebanese army on the Druze militia in a battle for the strategic hillside town of Souk el-Gharb. I was at the Marine base during one of the firefights when the commander ordered everyone into foxholes, including me. I asked a senior officer if I could first call in the news alert to the office. "Just one minute," he barked. I told an AP editor about the imminent attack. He wanted details. I did not have any; without asking, I handed the officer the phone. He gave the AP a hasty statement that Americans were about to launch an attack on the nearby hills. I was then escorted into a foxhole with a group of Marines. The firing started shortly afterward. That incident was the start of a bigger conflict between the U.S. and the militias.

Six months after the embassy bombing, a truck, carrying about 21,000 pounds of TNT, rammed into the Marine base, killing 241 Americans. Minutes later another truck blew up the French military barracks, killing more than 50. Three players were involved in the twin bombings, as with the U.S. Embassy blast: Syria, Iran and the Shia group that actually carried out the attacks. The latter two - despite repeated 
denials - would become the new powers that emerged as a result of Israel's invasion and a thorn in America's Mideast policy. The attacks, ranked as the largest loss of U.S. military life in a single incident since the World War II Battle of Iwo Jima, ${ }^{33}$ led to the humiliating departure of the multinational forces from Beirut after 533 days of deployment. It was one of America's first experiences with suicide bombings.

The security situation in Beirut was deteriorating by the day. At the same time, conspiracy theories abounded and the AP made sure to shoot them down with evidence, as I shall explain below. U.S. attempt to explain the security chaos in Lebanon in the Cold War context backfired: Americans leaked outrageous reports to the media - fed by the Lebanese intelligence close to the Phalange who were liaising with Israel's intelligence. One leak claimed the Soviets were planning an attack by Shia or Iranian "suicide pilots" on the Sixth Fleet, and alleged Soviet soldiers were spotted in the eastern Bekaa Valley. Labelle went to Baalbek to check out the rumors and found the report to be false. ${ }^{34}$

On Feb. 6, 1984, Druze and Shia militias wrested West Beirut from the army. The Marines were totally cut off and surrounded by the militias. The army they had trained, backed and funded had collapsed and splintered into rival Christian and Muslim factions. The following day, Reagan announced the "redeployment" of the Marines to ships offshore, taking the war to another level. On February 8, 1983, the battleship USS New Jersey fired more than 250 16-inch shells at what it said were Druze and Syrian artillery and missile batteries in the Syrian-controlled mountains. I interviewed civilian survivors in a hospital, whose homes had collapsed on their 
heads, and surveyed a home beside a crater 3.6 meters wide and one meter deep. ${ }^{35}$ There was no evidence of gun positions. We picked pieces of the shells to show the Marines; they had no comment.

Soon the MNF left Lebanon. The Americans did not allow the media to photograph their departure as they had when they arrived with great fanfare in September 1982. "It's not because your camera is dangerous. It's because some people consider the results, the reactions to the photographs, might be dangerous or I don't know how to put it - damaging to the foreign policy or something like that,"36 a U.S. Embassy spokesman told an AP photographer.

The country had disintegrated. The Israelis still occupied a third of the country, Syria occupied the Bekaa Valley and parts of the north. The Phalange controlled the Christian areas in east Beirut and central Lebanon. The government controlled almost nothing, only the presidential palace. The mood in West Beirut was becoming increasingly anti-Western. In February 1984, an American academic and a French engineer were kidnapped, to be rescued two months later by Amal militia. The kidnapping was claimed by the Islamic Jihad, the same group that attacked U.S. and MNF targets. On March 16, William Buckley, the CIA's station chief in Lebanon, was abducted. It would be the start of a long series of abduction of Westerners.

The AP avoided calling the abductors terrorists, as it did not refer to the Marine and U.S. Embassy bombings as terrorist acts. "From the point of view of the people who watched the attack, U.S. Marines were seen as an armed occupying force taking an active role in the Lebanese civil war," says former AP's Anderson 
(Appendix A, 1) whom I interviewed. ${ }^{37}$ But the AP did take U.S. diplomats at their word when they blamed Sheikh Mohammed Hussein Fadlallah, a senior Shia cleric, for the suicide bombings and kidnapping of the Western hostages..$^{38}$ From then on, Fadlallah was referred to in AP copy as Hezbollah's "spiritual leader" or "spiritual advisor" or "mentor." ${ }^{39}$ On March 8, 1985 the CIA masterminded a car bombing outside Fadlallah's home, killing 80 civilians and wounding about $200 .{ }^{40}$ Fadlallah escaped without injury. Confusion over his ties to Hezbollah would dog the media until his death in 2010. Fadlallah did support the Lebanese resistance against Israel's occupation, and he was a fierce opponent of U.S. policy in the region. "We are against the American policy that supports Israel, but we are not against the American people, American university professors, American intellectuals, American businessmen," Fadlallah told me in 1984, referring to the professions of some of the hostages. "In principle I am against all kidnappings. Also, we do not believe in acts such as blowing up embassies to defend our position, or hijacking planes and taking passengers hostage." ${ }^{11}$

Americans have little "ability to distinguish between the different strains of Islamist and Islamic thought," Anderson (Appendix A, 1) told me in the interview a day after Fadlallah's death. "The spiritual leader thing was a handy label. ... It allowed Western intelligence to blame him for all his followers' acts.” The man behind the kidnappings - and perhaps the suicide bombings - was believed to be Imad Mughniyeh, who was sought by U.S. authorities for years until his assassination in 
Damascus in 2008.42 "There was no face/picture of Imad Mughniyeh, they needed a picture to put a face on terrorists," said Anderson.

According to Chomsky, the danger of distorted labeling is that they are stored in archives and become history's narrative. Many of the younger generation of journalists in writing Fadlallah's obituary repeated the wrong information we had stored in the 1980s archives. ${ }^{43}$ Even CNN's Octavia Nasr, a Lebanese fired for expressing in a tweet her admiration for Fadlallah, was wrong when she described Fadlallah as "one of Hezbollah's giants."”44

For the next few years following the MNF's departure, the AP focused extensively on Israel's occupation of southern Lebanon, reporting on the daily attacks, ambushes and bombings: armed guerrillas, suicide bombers and ordinary people striking at the occupiers with sticks and stones, with boulders or felled trees across roads to block their path, with tires set afire to protest the occupation, and villagers holding protest rallies. The Israelis hit back with force - firing indiscriminately, making sweeping arrests and sealing off villages. ${ }^{45}$ They cut down and burned trees and broke down walls to prevent guerrilla ambushes. A grenade attack on their patrol elicited firing at crowded squares, killing civilians, followed by forced closure of shops for three days as punishment; they dug ditches, put up walls and surrounded their military posts with high mounds of earth. In one week they were ambushed 28 times with bombs and automatic fire. In one month they suffered 70 attacks. In one year there were 508 such incidents. ${ }^{46}$ While publicly proclaiming victory over the militants, south Lebanon increasingly became a death trap for the 
Israelis, who had apparently expected the same mute challenge in Lebanon as they faced from Palestinians in the occupied West Bank whose weapons were stones. They were taken aback by the professionalism of the Lebanese who were well versed in guerrilla warfare, ${ }^{47}$ something the Israelis were unfamiliar with and never managed to master. If Israel's intention of invading Lebanon was to secure its northern border from PLO attacks, it now had much more ruthless - and determined - Lebanese guerrillas to contend with. The action-reaction cycle became a familiar pattern as the predominantly Shia population of southern Lebanon resisted. Soon Hezbollah would emerge, carrying out most of the attacks, and over the years, Iran's influence would be embodied in Hezbollah, Lebanon's most robust, organized and sophisticated group, becoming a virtual state-within-a-state, with a small army of about 6,000 soldiers who fought off mighty Israel and forced it to end its 20-year occupation in $2000 .{ }^{48}$

In June 1985, the Israelis retreated to a 10-kilometer-deep strip just north of its border - calling it a "security zone," and eventually reduced its troops to about 1,000. The label was adopted in most of the AP copy examples of which are provided later. Israel justified its occupation of the border strip as a defense against attacks, not by the PLO anymore, but Lebanese guerrillas, whom it referred to as terrorists, although they had not attacked civilians nor fired rockets into Israel's northern Galilee before the invasion. Their main motivation at the time was to drive the occupation out ${ }^{49}$. Unlike the PLO, Hezbollah was an enormously popular grassroots Lebanese group with a huge following in the Shia population. ${ }^{50}$ While Hezbollah's creation was the result of the 1982 invasion and occupation of predominantly Shia south Lebanon, it 
is, however, doubtful that without Iran's financial, military, ideological, and political help, it would have developed into today's formidable force that has proven so far to be an unbeatable enemy for Israel.

The AP covered most of the incidents - big and small. Journalists spent days, sometime weeks, in the south. I reported a great deal from the southern village of Jibsheet that straddles two hills above the town of Nabatiyeh - eventually putting its name on the map as the birthplace of Shia resistance to Israeli occupation. Jibsheet's radicalism was inspired by a local young cleric, Sheikh Ragheb Harb, who was assassinated by Israel-run Lebanese militiamen in 1984. Harb's supporters would go on to transform into Hezbollah. One incident that was decisive in paving the way for Hezbollah's ascent occurred in Nabatiyeh on October 16, 1983 during the procession of Ashoura, a Shia religious ceremony. An Israeli army convoy that drove into a crowd of thousands was pelted by stones and one of its trucks set ablaze. The soldiers opened fire, killing two and wounding seven. The Israelis denied anyone was hurt, claiming soldiers had merely fired in the air to disperse the attackers. However, I interviewed the injured and visited the graves of the dead. With names and details, the AP was able to challenge Israel's denial. ${ }^{51}$

Violence in Lebanon became personal when AP bureau chief Terry Anderson was kidnapped on March 16, 1985. Labelle and his wife, Eileen Powell, also an AP journalist, and an American photographer left Lebanon. Foreigners of other news outlets also left. The Western hostages became AP's main focus of coverage, even though there were many more non-Western captives in Lebanon. I left several months 
later, and did not return to the Middle East on assignment until the fall of 1995, based in Jerusalem when I noticed a change in AP coverage.

Take the April 111996 Israeli military strikes on Lebanon that came after Hezbollah fired Katyusha rockets into Israeli-occupied south Lebanon and northern Israel on April 9 following the previous day's death of a Lebanese boy by a land mine that the UN and local residents said Israel had planted. ${ }^{52}$ I reported on the fighting from the Israeli side of the border. The attacks mostly killed Lebanese civilians and destroyed civilian infrastructures, including roads, water installations and power plants. ${ }^{53}$ Israel's justification for initiating the war, rarely challenged by the AP, was to stop Hezbollah from firing rockets. A search of online archives show that the AP did not specify in its stories the fact that Hezbollah had fired rockets on northern Israel in retaliation for the death of the Lebanese teenager on April 8. Days earlier, according to the UN, Israeli soldiers had planted a roadside explosive inside a UNcontrolled area - outside the Israeli-occupied zone in southern Lebanon - killing the teenager and wounding three people. This crucial information continued to be omitted from the timeline of the 16-day war coverage and after it ended. (According to a British newspaper report, Israeli soldiers had planted inside the UN zone plastic mines and booby traps that killed the Lebanese boy. Shortly after the Israeli bombardment ended, Israeli officers met UN ordnance officers and handed them detailed maps of the explosives they had planted. ${ }^{54}$ ) Only an April 19 "chronology"55 of the fighting mentioned that on April 8, a "Lebanese boy was killed by a land mine in southern Lebanon, with local residents accusing Israel of planting the mine."56 
While the UN also confirmed this, this crucial information was not in any of the 20 AP stories accessed on the Internet. On April 9, the AP chronology said, in response to the death, Hezbollah guerrillas began "firing Katyusha rockets into northern Israel daily." ${ }^{57}$ On April 10, Hezbollah guerrillas killed an Israeli soldier and wounded two more in attacks on "Israel's self-declared 'security zone' in south Lebanon." 58

A rudimentary study of $20 \mathrm{AP}$ stories ${ }^{59}$ on the 1996 fighting shows that little attempt was made to clearly explain the position of Lebanese guerrillas. Of the 20 stories - that included features - surveyed, seven referred without qualification to the Israeli attacks on Lebanon as retaliatory. The timeline almost always began with Israelis retaliating. For instance, "The Israeli air raid on Beirut - the second on the Lebanese capital in as many days - was in retaliation for Hezbollah guerrilla rocket attacks on northern Israel Friday morning." ${ }^{60}$ An April 9, 1996 story reported that Hezbollah said it fired "a barrage of rocket attacks at northern Israel," in retaliation for a land mine explosion that killed a Lebanese teen-ager. ${ }^{61}$ Note: Hezbollah "said." When reporting Israel's "retaliation" as in the above example, AP stories reported it as a given, without citing Israeli authorities.

Of the seven stories that made references to the Israeli-occupied strip of land, only one mentioned clearly that Israel was occupying Lebanon. The others called it: "the strip of land they [Israelis] control in southern Lebanon," 62 "security belt along the border manned by Israeli troops and a pro-Israeli Lebanese militia,"63 Israeli "presence in a narrow buffer zone," ${ }^{44}$ Hezbollah fighting "to drive Israeli troops from southern Lebanon," 65 "the border zone they [Israelis] hold in southern Lebanon to 
curb attacks on northern Israel." ${ }^{\prime 66}$ One story only helped to confuse: "Israel's top general emphasized yesterday that Israel has the right to return fire on Hezbollah guerrillas who attack Israeli soldiers from inside Lebanese villages, even if it causes civilian casualties." ${ }^{97}$ The story did not clarify that the general was referring to Hezbollah attacking Israeli soldiers inside the Israeli occupied area in Lebanon. This reductive interpretation of Israel's presence blurred the fact that Israel was illegally occupying a part of Lebanon - an informal fallacy based on misrepresentation of the topic of discussion.

An April 21, 1996 story made the following language choices: "Katyusha rockets continued to rain down on Kiryat Shmona and other northern settlements Saturday, and Israeli warplanes bombarded Hezbollah targets on the other side of the bother." ${ }^{\prime 8}$ In other words, Hezbollah bombed civilian communities, Israel bombed militia targets. Another paragraph referred to Israel's military operation as being "part of the escalating battle it is waging against the Iranian-backed Hezbollah in south Lebanon," which could mean that Israel was in fact fighting a proxy war with Iran, especially that the story did not mention Israel occupied a part of south Lebanon. "Israel blames Hezbollah guerrillas for the heavy civilian toll, accusing them of firing on Israel from inside Lebanese villages and using civilians as shields," said a story dated April 25, 1996, ${ }^{69}$ without giving context or showing skepticism about the unsubstantiated claim.

Lebanese views of the occupation that did appear sometime were scattered and confusing, while contrary perspective that blamed guerrillas for starting the 
violence was often clear and consistent. The AP featured at least one story ${ }^{70}$ from the 1996 fighting that was critical of Israel for not protecting its Arab citizens near the Lebanon border, who, unlike their fellow Jewish citizens, were not provided with government-built shelters.

The war culminated in the April 18 Israeli shelling of a UN base (a protected zone under international law) in the village of Qana and the death of 106 civilians, more than half of them children, who had taken refuge from the surrounding villages after being told by the Israelis to leave their homes. Israel and the U.S. blamed Hezbollah for the Qana massacre, saying the group used civilians as human shield. The UN Security Council, under pressure from the Clinton administration, refused to condemn Israel's Qana attack. The U.S. tried unsuccessfully to have UN Secretary-General Boutros Boutros-Ghali suppress a report blaming Israel for the massacre. Nonetheless, the U.S. media took the administration's charges at facevalue. ${ }^{71}$ After Boutros-Ghali did publish the findings - albeit watered down - the U.S. announced that it would use its veto if he ran again. ${ }^{72}$ On April 26, the U.S. negotiated a truce under which Hezbollah and Israel agreed - as they did in 1993 - to refrain from attacking civilians. ${ }^{73}$

Despite its declared objectivity, following the 1982 invasion and throughout the 1990s, value-laden labels had found their way into AP copy, language that was built into the definition of news, particularly about a country or group deemed unfriendly by the U.S. ${ }^{74}$ Examples are discussed in detail below. "Although individual words and phrases may not amount to very much in the great flow produced each day, 
language matters," wrote New York Times public editor Margaret Sullivan. ${ }^{75}$ Indeed language in the form of labels can help legitimize or delegitimize certain physical force. Value-laden language is used, for instance, to name certain kinds of political violence as terrorism for one group, and self defense for another. Journalists work as "integration propagandists," according to Karim Karim, integrating their audiences within dominant belief systems. ${ }^{76}$ Chomsky calls this system "brainwashing under freedom," a practice prevalent in democracies. The AP invariably referred to the 10kilometer deep strip inside Lebanon along the southern border that Israel occupied until 2000 as "security zone," "so-called security zone," "self-proclaimed security zone," "security belt," "buffer zone," or simply "buffer' - terminology that viewed the strip from Israel's standpoint. ${ }^{77}$ Israel's justification that it set up the zone to prevent guerrilla attacks on Israel - in effect legitimizing its occupation - was rarely questioned. The AP seldom, if at all, addressed the fact in news stories that the guerrillas were a resistance force trying to rid their country of foreign occupation, a legitimate act under international law; and more importantly, that Hezbollah was an outcome of the occupation. Take this paragraph from a September 8, 1997 story, which had become almost an AP template in reference to Israel-occupied strip of land. "Israel set up the security zone to protect its northern settlements from crossborder guerrilla attacks. About 1,200 Israeli soldiers and 2,500 militiamen patrol the zone." ${ }^{.78}$ Or this provocative lead from a Lebanon-dated story of September 9, 1997. "Gloating over the deaths of 11 Israeli soldiers killed in a commando raid into Lebanon, Shiite Muslim guerrillas showed off mutilated Israeli bodies yesterday and 
called the battle a grave defeat for Israel." 79 The third paragraph reads: "A 12th Israeli soldier was missing and presumed dead. Four others were wounded when the commandos came ashore early yesterday 30 miles north of the Israeli border - well outside Israel's security zone in southern Lebanon - and were met by Hezbollah militiamen and Lebanese army soldiers." Only in the 10th paragraph do we learn that Israel occupied Lebanese land. "Sheik Hassan Nasrallah, secretary-general of the Iranian-backed Hezbollah, warned Israel would encounter more roadside bombs and gunfire if it again attacks outside its occupation zone in the south." Two paragraphs down: "The raid was like scores of commando forays Israeli elite forces have made into Lebanon over the past 30 years. This time, however, the casualties were greater than in any combat action since Israel set up its occupation zone in 1985 to protect its northern border." Only at the bottom of the story does it mention that "Over the years, Israeli commando raids in Lebanon also have killed a Hezbollah leader and kidnapped two others, who remain in Israeli jails."

"Whatever it was called, the 22-year occupation of south Lebanon was a textbook demonstration of the American media's mind-controlling activities led by two giants - The Associated Press and the New York Times. During those 22 years the media worked tirelessly to re-characterize Israel's occupation of south Lebanon as something other than it was," according to Mitchell Kaidy, of the Washington Report on Middle East Affairs. ${ }^{80}$ "The term worked for disinformational purposes, but was purely propagandistic." Even Chomsky used the label in his book, The Fateful Triangle. ${ }^{81}$ 
The second value-loaded language and narrative was casting Israel as being reactive in responding to guerrilla actions, while Lebanese guerrillas were depicted as provoking Israeli attacks; in other words the guerrillas were portrayed as initiators in the cycle of tit-for-tat violence. Stories rarely said, for example, that Hezbollah attacks had in fact been in response to earlier Israeli assaults. The lead of an AP story dated November 17, $1993^{82}$ reads: "Hezbollah guerrillas Tuesday mounted their heaviest attack on Israeli-held territory in southern Lebanon ..., security officials said. Israel retaliated with air raids." By linguistically altering the narrative, blurring responsibility, and emphasizing Israel's security, the media failed to correctly define causes and effects. Questions as to what happened, where and how were addressed, but rarely, if at all, was it clarified as to why they happened. So coverage was often fudged, "facts" were made to fit evidence, and failed to make clear that the attacks were actually in response to Israeli aggression; emphasis on Israel being a democratic state and merely containing guerrillas as best as it possibly could become the dominant narrative. Timelines blurred historical facts to the point that violence, including suicide bombings, was often portrayed as the cause and origin of the conflict. With the sanitization of the language, Israel was shown as the victim trying to defend itself. One of the effects of the blurring of timelines was highlight in a study by Glasgow University that found many respondents believed it was the Palestinians who were occupying the Israeli-occupied Palestinian territories and not the Israelis. ${ }^{83}$

AP's New York editors interviewed for the thesis were generally unaware of the linguistic leavening in the copy; a few admitted their negligence was due to 
their preconceived views about Israel and Arabs. Ellen Knickmeyer, an American who worked on the foreign desk in the 1990s, explains:

You grow up reading news coverage that's crafted in a certain way and typically portrays the Israelis more sympathetically than the Arabs; that's the context you have, what you think is the situation. Almost everybody in the U.S., at least at the time I was growing up, was thinking Israel was this spunky little state that had to fight off its neighbors to survive as a country; [that] it was founded by Holocaust survivors. So most people grew up with a pretty sympathetic view of Israel. There's not a lot from the opposing side there (in America). There was an attack on the Munich Olympics, so a Palestinian was synonymous with terrorist in the U.S. ...There were people on the desk who had come from the Jerusalem bureau. But there were no Arabs on the desk when I was there.

Having cited some of the stories and how AP presented events, we now turn to some specifics, such as the employment of value-laden languages and timelines. Many AP stories without evidence identified targets of Israeli airstrikes as Hezbollah "strongholds," "suspected strongholds," "paths," or "'trails," yet most of the time, the casualties were civilian, and this contradiction did not factor in the stories. A May 4, 1993 lead and ensuing paragraph read ${ }^{84}$ : "Israeli helicopters and tanks attacked suspected Shia Muslim guerrilla bases in southern Lebanon today and security sources said two guerrillas were believed killed and seven people wounded. An eighth person, a Lebanese woman, was later wounded when Hezbollah guerrillas fired mortars and rocket-propelled grenades into Israel's self-designated 'security zone' in southern Lebanon, said the sources." 
Prior to 9/11, the AP stylebook had barred the use of the word "terrorist," but Hezbollah was frequently referred to as being "considered a terrorist organization" by the U.S. In other words, the AP went around the value-loaded word of "terrorist" by making it an official U.S. government label, not necessarily that of the news organization. A boilerplate ${ }^{85}$ in AP's computer system instructed the style-approved language to be inserted into stories, including language for how to refer to Hezbollah. As New York Times' Sullivan asserted, "When news organizations accept the government's way of speaking, they seem to accept the government's way of thinking." 86 This explains how shifts in language and metaphor make the Middle East unintelligible.

Repeatedly identifying Hezbollah as a Shia Muslim group reinforced the stereotypical characterization of Islam as an "ugly, intolerant and violent" religion, just as the word "fundamentalism" came to mean religious fanaticism in the Western media. $^{87}$

As we have seen, in reporting on Israel's conflicts, the source that dominated the narrative was often Israel, whether its government, army, politicians, or ordinary people. It often happened unconsciously as the journalist was unaware of the implications of the value-loaded language. According to Edward Said, ${ }^{88}$ foreign journalists reporting on Muslim countries are generally ill-equipped to provide adequate understanding of current events there. Except for a very few American journalists at the AP, most did not speak the language or have deep knowledge of the region and its modern history. This lack of expertise is even more acute today. Local 
employees of Western media had little understanding of how their part of the world was portrayed in the West, or were aware of the impact the narrative and nuances had on the West's understanding of the region. Over the decades of my employment with the AP, save for a handful with extensive knowledge of Islam and Mideast history, many of AP's local, non-American staffers were also not well-versed in the history, religion or even literature of their region. Their preconception of the Western media being free and unbiased allowed them to go with the flow.

Having put forward some of the theoretical and academic arguments of the three major narratives or value-laden language often used by the AP, I will feature the views and experiences of dozens of AP journalists - American, non-American and Middle Eastern. Their testimonies will enable us to walk through the process of source and news selection, and narratives. The study will demonstrate how these value-laden labels found their way in AP copy; journalists' opinions of them and whether they were aware of their impact. Personal opinions and experiences help determine if these practices stem from journalists' belief system. Journalists' mindset in applying the language is crucial to our understanding as to why they were seldom challenged.

Of the more than 25 journalists interviewed, 17 commented on the label, “security zone." Six of them said they were unaware of its value-laden nature or its implications. Nine, who were aware, had varying reasons for accepting or rejecting it; none challenged its use. Only one disputed the routine use of the label. A former senior editor in New York, who requested anonymity and shall be referred to 
as Interviewee B (Appendix A, 29) throughout the thesis, concedes the label "parroted the source," and that "the quote marks is meant to signal that Israel calls it that but 'hey the AP isn't calling it that. [It is a] failed attempt at objectivity.'

Ellen Nimmons (Appendix A, 20), AP's current assistant international editor, also acknowledges its frequent usage. "We tried to use neutral terms, but you can't always find them." Earleen Fisher (Appendix A, 5) finds it acceptable if clarified it was a label that Israel used. However, as I was to discover, using inverted commas or prefacing the label with self-declared, did not guarantee clarity that the area was occupied. Because of the label, a copy editor ${ }^{89}$ at Toronto's Globe and Mail in the early 1990 s told me she was under the impression that there was no Israeli presence there but run by its proxy Lebanese militias.

Former New York editor Leslie Shepherd (Appendix A, 25), a Canadians, makes a distinction between the views of a democratic state and a militia:

I think that somehow you can use different language when you're referring to a government as opposed to an opposition movement of any kind, whether a democratically elected opposition party or a grassroots movement or whatever. ... You give the benefit of the doubt by and large to an elected government with huge caveats.

A non-American editor in Cairo in the early 2000s, who shall be referred to as Interviewee C (Appendix A, 30), says:

We were not encouraged to add a broader perspective, or were simply habitually expected to follow the narrative that had become boilerplates. I guess it is self-censorship. You just don't venture out into uncharted waters. These narratives are what history is made of. ... [There was a] big difference in reporting from the Israeli side on one hand and Cairo on the other, with more pronounced pro-Israeli 
viewpoints expressed in Jerusalem stories, which tended to lack balance.

The internalization of the term "security zone" meant it was often accepted without thought. Even Arab reporters did not challenge it. One, Interviewee D (Appendix A, 31), explains: "You get programmed" that they become reality. Interviewee E (Appendix A, 32), another Arab, says: "To me, it was its name, I accepted it."

Of the six AP journalists who commented on the use of the word "retaliate" when describing Israeli responses to attacks, five said they were unaware of its implication; one disagreed that the word was value-loaded. Shepherd says she did not "necessarily infer retaliation as defense. "It was just the language we used at the time." She says she accepted the language filed by the bureaus at face value. "You were trying to make sure it was balanced."

Of the 12 journalists who commented on the label "the U.S. considers Hezbollah a terrorist" group, four said the fact that the AP caters mainly to U.S. newspapers justified its use; one had been unaware of its implication; one was dismissive; one did not believe it was routinely used; and three criticized its use, one of them only mildly. Interviewee B (Appendix A, 29), believes it was "a way for the AP to avoid labeling an organization on its own.”

Nimmons (Appendix A, 20) says the AP continues to use the label, and has added the European Union, which designated Hezbollah's military wing a terrorist organization in July 2013. "I think it's because we are looking for a short hand way to 
tell readers something about this group. And we would have to put a paragraph to explain what Hezbollah is, and that wouldn't do it fully, because there's a lot going on with Hezbollah.”

Donna Bryson (Appendix A, 3), an editor in New York and later Middle East news editor in Cairo, says: "I believe AP reporters strive for balance and fairness, but I know subtle language can leave readers convinced we don't. One unwritten rule that pertains here is the definition of terrorism and terrorist, labels used primarily for nonstate actors. A government is never described as terrorist, though the actions of some governments might arguably fit that description." She adds:

Reporters don't question their own language enough, and that might be a matter of the professionally shared values you mention. Our sense of what a journalist is, developed at university and in the workplace, is probably more to blame for conformity in the industry than the 'power' of top editors and an organization's culture.

Interviewee F (Appendix A, 32),says: "The references seemed fair and I was not conscious that these were loaded references. ... What similar qualifications [could we have used] for the other side? We couldn't possibly say the terrorist state of Israel, could we?"

This chapter laid out some of the changes the AP coverage underwent in reporting the Lebanon-Israel conflicts. In the early to mid-1980s, the AP. was at the forefront of providing news to the world, including local Lebanese media. It did not, for the most part, take at face-value rumors or information disseminated by interested parties, and reporters aggressively checked them out. On many occasions, Americans, Israelis, the warring militias had to retract charges - e.g. suicide pilot rumors, Israeli 
presence in refugee camps during the massacre, Israelis opening fire on crowds. Except for a few value-laden labels, AP copy was comprehensive.

By and large, AP's Mideast coverage in this period was - as Karim Karim would describe - as conscientious and informed ${ }^{90}$ and often reflected the reality despite the inbuilt Western preconceived biases about Arabs in favor of Israel, and despite the enormous power and influence of Israel behind the scenes at all levels of Western institutions. Journalists generally had the freedom to report what they saw and judged events without interference or guidance, as long as every effort was made to be accurate. They were not held back from making it clear when necessary that the Israelis were using extreme measures against civilians.

Over the years, however, coverage moved away from the more neutral to often taking Israel's position at face-value, as demonstrated in reporting the 1996 war. Timelines became increasingly one-sided, stories did not consistently give a full and fair account of the conflict (in some ways the picture was incomplete and often misleading). "The opposite of impartiality is partial coverage, that is, coverage which fails to mention relevant events or issues," said leading academic at Glasgow University Greg Philo. ${ }^{91}$ Selective use of material, ignorance of crucial evidence, and avoidance to go into vital areas of significance gave the impression that the Israelis were in constant self-defense mode. More on cause and effects will be discussed in chapter six.

As the American government became even more pro-Israel, so did the coverage. Failing to reflect properly the massive imbalance of power between the two 
sides: a state and an army with unprecedented American backing and massive weapons of war, and with virtually open-ended Western backing versus a small guerrilla group resisting occupation with rudimentary arsenal - AP copy increasingly depicted the Israelis as "victims," and Arabs as "the other," sometime even using inflammatory language to describe their actions as we saw in the September 6, 1997 story. ${ }^{92}$ Priority and more space were given to Israeli views of events; at the same time Lebanese guerrillas were cast as extremist Islamists, rendering them inferior and provocative. Failure to explain background and context - guerrilla reactions, whether violent or otherwise in the context of the continued occupation and Lebanese humiliation and suffering - and a reluctance to challenge Israeli views, further distorted the narrative and coverage.

Faced with an aggressive Israeli publicity machine, says Tim Llewellyn, the media - managers, middle managers and journalists - preferred to avoid and avert trouble and confrontation, they chose compliance rather than face charges of antiSemitism, which is more and more broadly used today to characterize anything that seems to contradict or criticize Israel's methods and interests. ${ }^{93}$ But the PR machine was not the only reason for the change in coverage. As Pipes noted, U.S. journalists could identify with the Israelis more than with Arabs, the "other," perhaps a hangover from history books and stories they heard growing up. Even the educated, the "liberal" with more questioning attitude, could not shake off the preconceptions. Also, there still seemed to be the inclination to trust the official word, the Israeli or American - as Shepherd notes - because they are democracies. Even non-Western 
journalists tended to accept their "otherness" and embrace the narrative that perhaps reduced them as a people to aggressors. If that was the narrative of a free media, then they must be true. When they eventually realized it was not the case, they were powerless to change the narrative, as Interviewee $\mathrm{C}$ (Appendix A, 30), asserts. They remained complacent. In other words, after years of such coverage, the audience - and the journalists - were instilled with the idea that though the killings and attacks by Israel were unwarranted and violent, "stuff happens" and the Arabs asked for it. This sentiment was dominant as we shall see during the 2006 war.

The unqualified support for Israel no longer had to do with the perception that it was weak and surrounded by hostile neighbors. Israel's army was the strongest in the region - thanks to U.S. assistance. Israelis boasted about their "superior" culture and technology over Arabs. A journalist said in an interview that during a briefing some years ago in Jerusalem, a senior AP official described the Palestinians as "primitive people" - an attribute reminiscent of the Orientalist construct of Arabs. The reporter, who divulged the information on condition of anonymity, says:

That was the first thing he told me, he was briefing me about Jerusalem, he was telling me about the Israel coverage. He said Palestinians are primitive people. He was just describing the conflict as he saw it. He said there had never been a good Arab military leader, the Arabs had never had a good military commander which is something I've heard since then from other people who have a pretty strong bias for Israel." 94

I contacted the AP official (Interviewee K: Appendix A, 37) by email and he denied it and also wished to remain anonymous. 
Another former AP journalist, Susan Sevareid (Appendix A, 24) covered

Israel's withdrawal in 2000 from the Lebanon-Israel border. Her testimony, as she told me in an interview, sheds light on the change that occurred in AP's coverage between 1982 and 2000. Throughout the day on May 25, 2000, Lebanese residents walked along the fence, pointing at soldiers, peering into Israel and breaking into chants that led to impromptu demonstrations. At one point, she says, Israeli soldiers started shooting at the demonstrators, some in the back as they ran. Sevareid telephoned her report to Cairo.

Later that day, I called in another update to the story and was told by the news editor in Cairo that New York had not yet moved the earlier lead with the injuries. She said they were holding it until Jerusalem could get Israeli army confirmation. The editor in New York, who was very senior and had vast Middle East experience, wondered how I could be sure the soldiers had inflicted the wounds and that they weren't caused by someone firing on the Lebanese side. I, on the other hand, wondered what in the world I was doing standing there getting shot at if New York wouldn't believe me until what I saw was confirmed by an Israeli army spokesman sitting in Jerusalem. While I was complaining, the confirmation came through and the update moved.

\section{Endnotes}

\footnotetext{
1 Richard Becker, Global Research, “Ariel Sharon: Serial War Criminal, Mass Murderer,” Jan. 13, 2014 http://www.globalresearch.ca/ariel-sharon-serial-war-criminal-mass-murderer/5364664?print=1

2 Richard Curtiss, Remembering the Sabra-Shatila Massacres, September 1987 -http://www.wrmea.org/ wrmea-archives/103-washington-report-archives-1982-1987/september-1987/834-remembering-the-sabrashatila-massacres.html

3 Jewish Virtual Library, "First Lebanon War: The Kahan Commission of Inquiry," Feb. 8, 1983- http:// www.jewishvirtuallibrary.org/jsource/History/kahan.html
} 
4 Thomas L. Friedman, New York Times, “The Beirut Massacre: The Four Days,” Sept. 26, 1982 - http:// www.nytimes.com/1982/09/26/world/the-beirut-massacre-the-four-days.html?pagewanted=4\&pagewant$\underline{\text { ed }=\text { all }}$

${ }^{5}$ Breaking News: How the Associated Press Has Covered War, Peace, and Everything Else, ed. Associated Press (New York: Princeton Architectural Press, 2007), p. 288.

${ }^{6}$ Benny Morris, The Righteous Victims: A History of the Zionist-Arab Conflict, 1881-1999 (New York: A. Knopf, 1999) p. 540.

${ }^{7}$ Ze'ev Schiff and Ehud Ya'ari, Israel's Lebanon War (New York: Simon and Schuster, 1984), p. 251.

${ }^{8}$ Amnon Kapeliouk, Sabra \& Shatilla: Inquiry into a Massacre, translated from French by Khalil Jahshan (Belmont, MA: Association of Arab-American University Graduates, 1984), pp. 49-50.

${ }^{9}$ Prime Minister's Office, Israel State Archives, "The Kahan Commission on the Sabra and Shatila Massacre," 10 February 1983 -http://www.archives.gov.il/ArchiveGov_Eng/Publications/ElectronicPirsum/KahanCommission/. See also, Ze'ev Schiff and Ehud Ya'ari, Israel's Lebanon War (New York: Simon and Schuster, 1984), p. 279-80.

10 Scheherezade Faramarzi, AP published in Philadelphia Inquirer, "Survivors: Israelis Watched Massacre," P. 14-A, Dec. 22, 1982.

11 Jewish Virtual Library, "First Lebanon War: The Kahan Commission of Inquiry," p. 104, Feb. 8, 1983 http://www.jewishvirtuallibrary.org/jsource/History/kahan.html

12 This belief was confirmed by an Israeli military prosecutor, according to a 2012 report by Defence for Children International funded by the UK government, 2012. See Amira Haas, Ha'aretz, "U.K. slams Israel with stiff upper lip: Not all Palestinian kids are potential terrorists," Jul. 9, 2012 -http://www.haaretz.com/ news/features/u-k-slams-israel-with-stiff-upper-lip-not-all-palestinian-kids-are-potential-terrorists-1.449784

${ }^{13}$ Marcus Eliason, AP accessed through LexisNexus, Sept. 25, 2006.

14 James Feron, New York Times, "West Beirut siege is affecting Israelis' self image,” August 23, 1982 http://www.nytimes.com/1982/08/23/world/west-beirut-seige-is-affecting-israelis-self-image.html

15 ibid.

${ }^{16}$ AP story accessed in LexisNexis; Also see: Amir Oren, Ha'aretz, "1982 memo shows Israel learned little from first Lebanon War," Jul 12, 2009 - http://www.haaretz.com/print-edition/features/1982-memo-showsisrael-learned-little-from-first-lebanon-war-1.279802

17 Barak Ravid, Haaretz, "Think tank: Israel's poor international image not the fault of failed hasbara," Dec.30, 2012. http://www.haaretz.com/news/diplomacy-defense/think-tank-israel-s-poor-international-image-not-the-fault-of-failed-hasbara.premium-1.490718

18 ibid.

19 Professor Robert Jensen, Documentary, "Peace, Propaganda \& the Promised Land: U.S. Media \& the Israeli-Palestinian Conflict,” 2004. http://www.youtube.com/watch?v=cAN5GjJKAac

20 ibid. 
21 Shrewdly tactful.

22 AP moved its Israel bureau from Tel Aviv to Jerusalem in 1987.

23 According to an AP reporter who asked not to be identified. According to Steven Gutkin, during his tenure as AP's Jerusalem bureau chief between 2004 and 2010, the AP staff was made up of mostly Israeli Jews and Palestinian Muslim, with a smaller number of non-Jewish and non-Muslim foreigners. Steven Gutkin, Goa Streets, "My Life As An AP Bureau Chief In Israel," September 5, 2014. http://www.goastreets.com/life-ap-bureau-chief-israel/

24 Robert Fisk, Pity the Nation: The Abduction of Lebanon. (UK: Andre Deutsch, 1990).

25 Chomsky, op cit.

26 ibid.

27 ibid.

28 Daniel C. Hallin, The "Uncensored War": The Media and Vietnam, (California: University of California Press, 1989).

29 Daniel Pipes, New Republic, “Lebanon Eyewitness,” Aug. 2, 1982 - http://www.danielpipes.org/166/themedia-and-the-middle-east

30 Scheherezade Faramarzi, The Galveston Daily News, "Exporting Islamic fundamentalism to Lebanon, Nov. 6, 1982. http://www.newspapers.com/newspage/16609382/

31 Angus Richard Norton, Hezbollah: A Short History, New Jersey: Princeton University Press, 2005.

32 Association for Diplomatic Studies and Training, "The Bombing of U.S. Embassy Beirut," April 18, 1983. http://adst.org/2013/04/the-bombing-of-u-s-embassy-beirut-april-18-1983/

33 Arlington Cemetery, "Suicide bomber killed 241 American troops 25 years ago in barracks" Oct. 23, 2008. http://www.arlingtoncemetery.net/terror.htm

34 Fisk, op cit. p. 523.

35 Scheherezade Faramarzi, AP published in The Gettysburg Times, "Victims tell of terror shelling by battleship New Jersey,” Feb. 14, 1984. http://www.newspapers.com/newspage/47524262/

36 Fisk, op cit. p. 534n.

37 Terry Anderson. Personal interview, Beirut, Lebanon. July 2010.

38 See for example, Donna Abu-Nasr, AP archives, "Hezbollah Leader Wants Hostage Issue Solved," Jul. 24, 1988. http://www.apnewsarchive.com/1988/Hezbollah-Leader-Wants-Hostage-Issue-Solved/ id-9758dea1a4e509496c50c357a04afd28 
${ }^{39}$ See for example, Hamza Hendawi, AP published in Washington Post, "Lebanese Cleric Derides Bush Policies," Sept. 27, 2006. http://www.washingtonpost.com/wp-dyn/content/article/2006/09/27/ AR2006092701269 pf.html

40 Washington Post reporter Bob Woodward's Veil: The Secret Wars of the CIA 1981-1987, reveals that CIA Director William Casey, funneled money to a professional hit team to assassinate Fadlallah. Also, according to former CIA case officer Robert Baer who worked in Beirut during the 1980s, is quoted by Foreign Policy as saying: "I can guarantee you, and I have seen every bit of intelligence, that Fadlallah had no connection [to the attacks]. ... He wasn't our friend, let's get that straight, but that doesn't mean he was a master terrorist." See David Kenner, Foreign Policy, July 6, 2010, http://www.foreignpolicy.com/ articles/2010/07/06/the sheikh_who_got_away

${ }^{41}$ Material drawn from notes of Fadlallah interview with author July 31, 1984.

42 Scheherezade Faramarzi, AP archives, "Slain Hezbollah commander Mughniyeh was a key organizer of 2006 war with Israel," Feb. 26, 2008. http://www.highbeam.com/doc/1A1-D8V288104.html

${ }^{43}$ See for example, Borzou Daragahi, Los Angeles Times, "Top Lebanese Shiite cleric Fadlallah dies at 75," July 5, 2010. http://www.sfgate.com/news/article/Top-Lebanese-Shiite-cleric-Fadlallah-diesat-75-3182372.php

44 Octavia Nasr, Jul 4, 2010 via Twitter - octavianasrCNN

45 Scheherezade Faramarzi, AP published in Tulsa World, "Cycle of Resentment Grows in Israeli-occupied Lebanon," May 13, 1984.

46 ibid.

${ }^{47}$ Fisk, op cit.

48 Scheherezade Faramarzi, AP story in Roth Army, "Hezbollah puts down deep roots," Aug. 21, 2006. http://www.rotharmy.com/forums/archive/index.php?t-39537.html

${ }^{49}$ Norton, Augustus Richard, Hezbollah: A Short History (New Jersey: Princeton University Press, 2007).

50 Fadi Derbass, review of his book in Arab News, "What led to the rapid increased popularity of Hezbollah in Lebanon?" 12 June 2013. http://arabnews.us/index.php/en/home/9-2013-04-30-13-59-49/295-whatled-to-the-rapid-increased-popularity-of-hezbollah-in-lebanon-search-by-dr-khader-hawthorn

${ }^{51}$ My AP story is unavailable on the internet, however reference to the incident is made by Robert Fisk who traveled with me to Nabatiyeh. See: Adonis Diaries, "Genesis of Hezbollah of Lebanon: Connecting the dots," Sept. 21, 2011. http://adonis49.wordpress.com/2011/09/21/part-3-genesis-of-hezbollah-oflebanon-connecting-the-dots/

52 Chronology of Recent Fighting, AP archives, April 19, 1996.http://www.apnewsarchive.com/1996/ Chronology-of-Recent-Fighting/id-7608f3ed94a7e12aca9de9e540bddcba?SearchText=lebanon\%20April \%201996\%20hezbollah\%20israel\%20; Display 
53 A high-ranking Israeli officer in Kiryat Shmona in 1996, in response to my query as to why his army was attacking civilian sites, said they wanted to destroy Lebanon's - not Hezbollah's - economic infrastructure.

54 Robert Fisk, The Independent, "The Deadly Secret that Led to Bloodbath at Qana," June 1, 1996. http:// www.independent.co.uk/news/world/the-deadly-secret-that-led-to-bloodbath-at-qana-1334867.html

55 AP Archives, “CHRONOLOGY OF RECENT FIGHTING,” Apr. 19, 1996.http://www.apnewsarchive.com/1996/Chronology-of-Recent-Fighting/id-7608f3ed94a7e12aca9de9e540bddcba?SearchText=lebanon \%20April\%201996\%20hezbollah\%20israel\%20; Display

56 According to Interviewee D (Appendix A, 31) this entry was only added after a local journalist brought it to the attention of the news editor who was writing the chronology, which originally began with the Hezbollah rocket attacks.

57 AP Archives, "CHRONOLOGY OF RECENT FIGHTING,” Apr. 19, 1996.http://www.apnewsarchive.com/1996/Chronology-of-Recent-Fighting/id-7608f3ed94a7e12aca9de9e540bddcba?SearchText=lebanon \%20April\%201996\%20hezbollah\%20israel\%20;Display

58 ibid. 
59 AP archives, "Guerrillas Fire Katyusha Rockets on Northern Israel," April 9, 1996; "Israelis Again Fire on Rebel Hub in Beirut," April 12, 1996. http://www.deseretnews.com/article/483092/ISRAELIS-AGAINFIRE-ON-REBEL-HUB-IN-BEIRUT.html?pg=all; Barry Schweid, AP archives, "Christopher Works on Agreement to Halt Israel-Hezbollah Conflict," April 15, 1996. http://www.apnewsarchive.com/1996/ Christopher-Works-on-Agreement-to-Halt-Israel-Hezbollah-Conflict/idd5ee2ce426cb3e7b1103ce545c5e01d8? SearchText=lebanon\%20April\%201996\%20hezbollah\%20israel \%20;Display_ Hussein Dakroub, The Brownsville Herald, "Israel-Hezbollah battles claim more lives in Lebanon," April 16, 1996. http://newspaperarchive.com/us texas/brownsville/brownsville-herald/ 1996/04-16/page-3; Jack Katzenell, AP archives, "Overwhelming public support for bombardment of Lebanon,” April 16, 1996. http://newspaperarchive.com/us/texas/brownsville/brownsville-herald/ 1996/04-16/page-3; Dianna Cahn, AP archives, "Israelis Flee Rocket Fire, But Strongly Support War," April 16, 1996; Nicolas B. Tatro, AP archives, "U.S. Truce Proposals: International Monitoring and Syrian Guarantee, April 17, 1996. http://www.apnewsarchive.com/1996/U-S-Truce-Proposals-International-Monitoring-And-Syrian-Guarantee/id-ecf4922d8d05458c41da4e6c2a8e3ade?SearchText=lebanon\%20April \%201996\%20hezbollah\%20israel\%20;Display_; Scheherezade Faramarzi, AP, "Israeli Arabs: Government doesn't protect us from rockets." April 17, 1996, http://www.apnewsarchive.com/1996/Israeli-Arabs-Government-Doesn-t-Protect-Us-from-Rockets/id-0c8ba8001532115d3049f10e087f8e3f?

SearchText=Scheherezade\%20faramarzi\%201996\%20Arab\%20Israelis\%20shelters\%20;Display; Robert H. Reid, AP archives, Pressure Mounts in Security Council for Cease-fire in Lebanon, April 18, 1996; Tarek al-Issawi, AP archives, "Israeli Aircraft Attack Apartment Building in Southern Lebanon, 11 Killed," April 18, 1996, http://www.apnewsarchive.com/1996/Israeli-Aircraft-Attack-Apartment-Building-inSouthern-Lebanon-11-Killed/id-0aflbc2f474a8cd46a22dc5f803551d5; AP published in Arizona Daily Wildcat, "Israeli attack kills 75 UN refugees," April 19, 1996. http://wc.arizona.edu/papers/ 89/141/01_2_m.html; AP archives, "Chronology of Recent Fighting," April 19, 1996. http://www.apnewsarchive.com/1996/Chronology-of-Recent-Fighting/id-7608f3ed94a7e12aca9de9e540bddcba?SearchText=lebanon\%20April\%201996\%20hezbollah\%20israel\%20;Display ; Dafna Linzer, News Press, April 21, 1996. http://archives.savannahnow.com/sav_pdf_archive/text/fr147/A_2323472.pdf; Sam F. Ghattas, AP archives, "Christopher in Lebanon, Israeli Warplanes, Gunboats in Action," April 24, 1996. http:// www.apnewsarchive.com/1996/Christopher-In-Lebanon-Israeli-Warplanes-Gunboats-In-Action/idac712413140aa0068461a6312b7a5c05?SearchText=lebanon\%20April\%201996\%20hezbollah\%20israel \%20;Display; Hilary Appelman, AP archives, "Israelis Say Fighting to Prevent New Tragedy," April 25, 1996; Louis Meixler, AP archives, "UN General Assembly Condemns Israeli Attack on Civilians in Lebanon," April 26, 1996. http://www.apnewsarchive.com/1996/U-N-General-Assembly-Condemns-Israeli-Attack-on-Civilians-in-Lebanon/id-ef6ad8298d968f103c7ce9727f26198a?SearchText=lebanon \%20April\%201996\%20hezbollah\%20israel\%20;Display_; Tarek Al-Issawi, South Coast Today, "Lebanese refugees go home." Saturday April 28, 1996. http://www.southcoasttoday.com/apps/pbcs.dll/article?AID=/ 19960428/NEWS/304289998; Robert H. Reid, AP archives, "Israel's Artillery Commander Denies UN Camp was Targeted," May 6, 1996. http://www.apnewsarchive.com/1996/Israel-s-Artillery-CommanderDenies-U-N-Camp-Was-Targeted/id-b31cdd71ba2242d2a6dd1d903f864bf3; AP published in Los Angeles Times, "Videotape Supports Claims Israel Targeted UN Base," May 7, 1996. http://articles.latimes.com/ 1996-05-07/news/mn-1404_1 u-n-base; Nicolas B. Tatro, AP archives, "Peres Says UN Report One-sided, Israel Releases Own Video," May 8, 1996. http://www.apnewsarchive.com/1996/Peres-Says-U-N-ReportOne-Sided-Israel-Releases-Own-Video/id-093623e23748028d9a3fa8d88e3d0fc1?SearchText=lebanon \%20April\%201996\%20hezbollah\%20israel\%20;Display; Nicolas B. Tatro, AP archives, "Israel Blames Peackeepers for Contributing to Qana Shelling Tragedy," May 15, 1996. http://www.apnewsarchive.com/ 1996/Israel-Blames-Peacekeepers-For-Contributing-To-Qana-Shelling-Tragedy/id-6e66bec43ff9d55ffc84718eaba3061d?SearchText=lebanon $\% 20$ April $\% 201996 \% 20$ hezbollah $\% 20$ israel $\% 20$; Display

60 AP published in Desert News, "Israelis Again Fire on Rebel Hub in Beirut," April 12, 1996. http:// www.deseretnews.com/article/483092/ISRAELIS-AGAIN-FIRE-ON-REBEL-HUB-IN-BEIRUT.html? $\mathrm{pg}=$ all

61 AP archives, “Guerrillas Fire Katyusha Rockets on Norther Israel,” April 9, 1996 
62 AP published in Desert News, "Israelis Again Fire on Rebel Hub in Beirut," April 12, 1996. http:// www.deseretnews.com/article/483092/ISRAELIS-AGAIN-FIRE-ON-REBEL-HUB-IN-BEIRUT.html? pg=all

63 Barry Schweid, AP archives, "Christopher Works on Agreement to Halt Israel-Hezbollah conflict," April 15, 1996. http://www.apnewsarchive.com/1996/Christopher-Works-on-Agreement-to-Halt-Israel-Hezbollah-Conflict/id-d5ee2ce426cb3e7b1103ce545c5e01d8?SearchText=lebanon\%20April\%201996\%20hezbollah\%20israel\%20;Display

64 Dianna Cahn, AP archives, “Israelis Flee Rocket Fire, But Strongly Support War, April 16, 1996.

65 Hussein Dakroub, The Brownsville Herald, "Israel-Hezbollah battles claim more lives in Lebanon," April 16, 1996. http://newspaperarchive.com/us/texas/brownsville/brownsville-herald/1996/04-16/ page-3

66 Tarek al-Issawi, AP archives, "Israeli Aircraft Attack Apartment Building in Southern Lebanon, 11 Killed. April 18, 1996.

${ }^{67}$ Tarek al-Issawi, AP published in South Coast Today, "Lebanese Go Home," April 28, 1996. http://www.southcoasttoday.com/apps/pbcs.dll/article?AID=/19960428/NEWS/304289998

${ }^{68}$ Dafna Linzer, News Press, April 21, 1996. http://archives.savannahnow.com/sav_pdf_archive/text/fr147/ A 2323472.pdf

${ }^{69}$ Hilary Appelman, AP archives, "Israelis Say Fighting to Prevent New Tragedy,” April 25, 1996.

70 Scheherezade Faramarzi, AP archives, "Israeli Arabs: Government doesn't protect us from rockets." April 17, 1996, http://www.apnewsarchive.com/1996/Israeli-Arabs-Government-Doesn-t-Protect-Us-fromRockets/id-0c8ba8001532115d3049f10e087f8e3f?SearchText=Scheherezade\%20faramarzi \%201996\%20Arab\%20Israelis\%20shelters\%20;Display

71 AP published in Arizona Daily Wildcat, "Israeli attack kills 75 UN refugees," April 19, 1996. http:// wc.arizona.edu/papers/89/141/01_2 m.html. See also: Robert H. Reid, AP archives, "Israel's Artillery Commander Denies UN Camp was Targeted," May 6, 1996. http://www.apnewsarchive.com/1996/Israel-sArtillery-Commander-Denies-U-N-Camp-Was-Targeted/id-b31cdd71ba2242d2a6dd1d903f864bf3

72 Eric Rouleau, Le Monde diplomatique, "Why Washington wants rid of Mr. Boutros-Ghali," November 1996 -http://mondediplo.com/1996/11/un

${ }^{73}$ Norton, op cit.

74 Herbert Gans, Deciding What's News: A Study of CBS Evening News, NBC Nightly News, Newsweek and Time (Chicago: Northwestern University Press, 1979). Gans was mainly referring to Communist countries, but this theory can be applied to anywhere the US regards as unfriendly.

75 Margaret Sullivan, New York Times, “Targeted Killing,' 'Detainee' and 'Torture': Why Language Choice Matters," April 12, 2013. http://publiceditor.blogs.nytimes.com/2013/04/12/targeted-killing-detainee-andtorture-why-language-choice-matters/? $\mathrm{php}=$ true \& type $=\mathrm{blogs \&} \_\mathrm{r}=0$

76 Karim H. Karim, Islamic Peril: Media and Global Violence (Montréal: Black Rose, 2003). 
77 AP story published in the Los Angeles Times, "Israeli, Arab Gunners Duel on Lebanon Border," Jan. 31, 1991. http://articles.latimes.com/1991-01-31/news/mn-622 1 israeli-settlement. See also: AP story published in the Los Angeles Times, "Israeli-Backed Militia Returns Guerrilla Fire," Feb. 28, 1993. http://articles.latimes.com/1993-02-28/news/mn-423_1_south-lebanon-army

78 AP published in the Los Angeles Times, "Guerrillas attack Israeli-occupied zone," Sept. 8, 1997. http:// www.southcoasttoday.com/apps/pbcs.dll/article?AID=/19970908/NEWS/309089984\&emailAFriend=1

79 AP story published in Desert News, "Israel military 'in pain' after loss in Lebanon, Sept. 6, 1997. http:// www.deseretnews.com/article/581302/Israel-military-in-pain-after-loss-in-Lebanon.html?pg=all

80 Mitchell Kaddy, Washington Report on Middle East Affairs, Disinformation in the U.S. Media Turned Occupied Territory into Israel's 'Security Zone,' July 2000. http://www.questia.com/magazine/

1P3-509431111/disinformation-in-the-u-s-media-turned-occupied-territory

${ }^{81}$ Chomsky op cit.

82 AP published in the Los Angeles Times, "Guerrillas Attack in S. Lebanon," Nov 17, 1993. http://articles.latimes.com/1993-11-17/news/mn-57785_1_southern-lebanon examples

83 Greg Philo and M. Berry, Bad News from Israel (London: Pluto, 2004) pp. 261-275.

84 Edmond Shadid, AP archives, "Seven Wounded in Israeli copter Raid, 2 Killed in Tank Fire," May 4, 1993. http://www.apnewsarchive.com/1993/Seven-Wounded-In-Israeli-Copter-Raid-2-Killed-in-Tank-Fire/ id-9b04ea2f7477bba5af8fe20fd04207be

${ }^{85}$ Boilerplate is phrases or sentences that are a standard way of saying something and are often used (source: Webster dictionary)

${ }^{86}$ Sullivan, op cit.

${ }^{87}$ Karim, opt cit. p. 34.

88 Edward W. Said, Covering Islam: How the Media and the Experts Determine How We See the Rest of the World (New York: Vintage Books, 1981).

89 The Globe and Mail editor, who shall remain anonymous, has not been quoted anywhere in the thesis.

${ }^{90}$ Karim H. Karim, Islamic Peril: Media and Global Violence (Montreal: Black Rose Books, 2002) p. 179.

91 Report of the Independent Panel for the BBC Governors on Impartiality of BBC Coverage of the IsraeliPalestinian Conflict, April 2006. http://www.bbc.co.uk/bbctrust/assets/files/pdf/our_work/govs/panel_report final.txt

92 Ahmed Mantash, AP published in South Coast Today, "Guerrillas gloat over slain Israelis," Sept. 6, 1997. http://www.southcoasttoday.com/apps/pbcs.dll/article?AID=/19970906/NEWS/ $\underline{309069921 \& \text { emailAFriend }=1}$

93 Tim Llewellyn, "The BBC Bias: Firmly in the Arms of Zion, Media talks at Nottingham (March 15) and Istanbul (April 22-23), 2014. Transcript of the lecture provided by Llewellyn. 
Competing Narratives

94 The journalist wished to remain anonymous. 


\section{Chapter 4: "War on Terror"}

"They hate our freedoms - our freedom of religion, our freedom of speech, our freedom to vote and assemble and disagree with each other." - George W. Bush, Sept. 20, 2001 ${ }^{1}$

'Muslims do not 'hate our freedom,' but rather, they hate our policies. The overwhelming majority voice their objections to what they see as one-sided support in favor of Israel and against Palestinian rights, and the longstanding, even increasing support for what Muslims collectively see as tyrannies, most notably Egypt, Saudi Arabia, Jordan, Pakistan, and the Gulf States. Thus, when American public diplomacy talks about bringing democracy to Islamic societies, this is seen as no more than self-serving hypocrisy." - Unclassified study published by the U.S. Defense Science Board in 2004. ${ }^{2}$

September 11, 2001 was a catalyst in the transformation of mainstream U.S.

media - particularly in their coverage of the Middle East and Islam. Academic Silvio Waisbord ${ }^{3}$ describes $9 / 11$ as a watershed moment that brutally rattled the American consciousness of stability and protection.

This chapter examines how the 2001 attacks impacted AP coverage of the Middle East. Many of today's "veteran" foreign correspondents began their career shortly before or at the outset of 9/11, armed with a high dose of patriotism and a new "bad guy" vs the traditional "good guy" narrative. The "bad guys," being Muslim "terrorists" - were framed in a way that encompassed the world's Muslim population at large - who hate Western freedom and are bent on undermining its democracy. The narrative of the two ensuing wars in Afghanistan and Iraq were framed as "retaliation" for 9/11: to punish the "bad guys," and the Western "saviors" freeing the Afghan and Iraqi people of dictatorships and bringing democracy to them. This chapter briefly examines AP`s coverage of 9/11 and will focus mainly on the 
controversial months leading up to the Iraq war. It will include interviews with former and current AP journalists regarding the drastic changes in the coverage, and ask if journalists were under pressure from top editors and management to adhere to a patriotic tone, toe the government line. It will ask how they dealt with such pressures, if any, including pressures to verify reports of Iraq's weapons of mass destruction or its al-Qaida links. How did they conform to a set of new standards, and how patriotism affected the AP coverage? Four events that provide glaring examples of the changes will be discussed: the August 2003 killing of six Iraqi civilians in Baghdad by U.S. soldiers, the 2004 attack on a wedding party, mainstream Muslims in Europe, and the 2007 seizure of a British ship by Iranians in the Persian Gulf.

The immediate change that occurred at the AP after 9/11 was the loose use of the word "terrorism," because it had become part of the lexicon of American public mood. "There was a general recognition that there was a difference, some attacks were intended mostly to make the general population afraid as opposed to taking out a specific target," explains Ellen Nimmons (Appendix A, 20), AP's assistant foreign editor. The AP, she adds, is still careful about its usage. "We take our cues from both officials and from the people who carry it out themselves. There are of course groups that proudly profess what they're up to, to make people afraid and others who say it's all about strategy." She continues: "I think what 9/11 did was it woke a large part of the population to the fact that attacks are sometimes intended to terrify people."

To give comfort to a grieving, shocked country, Waisbord explains, mainstream media reverted to nationalism and hawkish patriotism, which provided 
the script to make $9 / 11$ intelligible. Uncritically, mainstream media propagated patriotism as both a cultural comfort and an analytical framework from which to understand risk. As a result, a "culture of fear"4 took shape as the media, echoing the government, helped perpetuate hate, echo calls for revenge, and exaggerate al-Qaida's organizational sophistication. Unwilling to challenge the blatant biases, they "offered a vision of a country in panic, reeling from the September 11 attacks. ${ }^{5}$

However, almost all former and current AP journalists interviewed say no one was explicitly instructed to make the coverage patriotic. Although some mainstream media reporters swallowed the government line (Judith Miller and the New York Times $^{6}$ being prime examples), AP's GG Labelle (Appendix A, 13) doubts news organizations became shills for the government. Former Mideast chief Earleen Fisher (Appendix A, 5) says she did not see any "glaring cases" where reporters "totally bought into the American propaganda machine." There was, however, a marked lack of critical and analytical attitude toward the Bush administration and its actions that conflicted with the freedom of the press and other freedoms, and later in its efforts to rally support for war. Objective reporting out of AP's Washington bureau was a greater challenge, says Interviewee B (Appendix A, 29), a senior editor in New York at the time of 9/11, because the White House's broad definition of terrorists came to dominate AP's narrative and language. Says Interviewee B (Appendix A, 29):

There was great frustration among AP journalists in Washington and especially in New York about the lack of reportable evidence provided by the Bush administration. Other news organizations were basing reports on anonymous Iraqi and other foreign officials who claimed to 
have insider information about Saddam's purported WMD program. There was some pressure on reporters to track down some of these same sources to stay competitive with the competition, particularly the New York Times. But AP reporters were far more skeptical of these anonymous sources than the Bush White House and even some other major news organizations. AP did quote the White House as insisting there was evidence of Saddam's WMD program. And of course AP gave major coverage to Secretary of State Colin Powell's infamous presentation $^{7}$ at the UN which led up to the war. AP also gave credence to the British report ${ }^{8}$ that also appeared to confirm the U.S. conclusion that Saddam had WMD and would use them. Bottom line: AP gave great credence to the Bush administration's accusations even as reporters and top editors behind the scenes were highly skeptical because no real smoking gun evidence was presented.

Labelle (Appendix A, 13) agrees: "Leading up to the invasion of Iraq, I recall there was chatter on the AP International Desk about how the Washington copy seemed soft on the president." Another senior editor in New York, Interviewee G (Appendix A, 34), says pressure came "from the news leadership of the AP in New York who had ties or conversations with people in the government. ... But I never witnessed any of that ... I saw the consequences of where we just didn't report.” The interviewee would not elaborate on who the news leadership were. It was not clear where the pressures stemmed from, says retired AP Special Correspondent Charles J. Hanley (Appendix A, 8), who covered the weapons inspections of 2002-2003 from Iraq, New York and Washington, and wrote some of the very few "skeptical" articles in the lead-up to the war. He adds in an interview for this thesis:

The problems were of several kinds, and the sources of the problems were often unclear. For example, I recall three Iraq-dated WMD stories of mine that I considered important - in the lead-up to the invasion - 
being spiked without discussion or notification. In all three cases, because of our communications situation in Baghdad, I didn't realize until a cycle or two later that they hadn't moved. I never knew who was responsible (my gut told me INT [international] was vetting my stuff with WDC). We were filing through the pre-war War Desk in Doha, which told me they didn't know what happened.

After America and Britain launched "Operation Enduring Freedom" against Afghanistan on Oct. 7, 2001, and later the Iraq war, dubbed "Operation Iraqi Freedom," coverage became centralized and a tightly controlled desk was set up. For every shift, there was an editor on the "war desk," helped by a lead editor and a number of other editors, all under senior managers. While before the war bureaus were able to file to the world or regional wires without passing through the U.S. filter, all copy now had to be filtered through New York or Washington, depending on the shift, says Ron Kampeas, who was an editor on the AP desk in Washington at the outset of the Iraq invasion. The afternoon "PM cycle" was written out of Washington and the morning "AM cycle" in Baghdad - in effect bypassing the Cairo bureau which was AP's Middle East control bureau. Says Kampeas (Appendix A, 11):

It was never explained why, but it seemed clear that editors were wary of an increased ability by readers in the U.S. to read overseas copy through the internet, and that they wanted to maintain a uniform narrative. It would have been embarrassing for AP to run a 'patriotic' story on the A-wire and one less so, say, in Germany or Latin America. Watching 'incoming,' I noticed that the DC rewrite would incorporate only copy from embeds, and not copy from non-embeds. It seemed clear to me the reason for this was to run copy that made it seem as if the war was going smoothly.

Consequently stories became so confusing, says Interview G, that it was "difficult to make sense of the copy," even though there were several reporters in the 
field in Afghanistan and later in Iraq. Reporters on the ground were filing notes to be written in New York instead of complete stories, rendering the process extremely frustrating for the many journalists and senior editors based in the Middle East, including those on a desk set up in Doha, Qatar, which was seen as a "failed operation."

"It's a good example of New York taking over and directing coverage," says Interviewee G (Appendix A, 34),. "The problem is New York thought they knew better about what the story should say than the guys on the ground.” New York's takeover of the coverage meant it "assigned a clear narrative" for the war where there rarely is clarity to begin with, says Interviewee G. Another senior manager Interviewee H (Appendix A, 35) - believes this move was not "so much of an attempt to influence the content of the news story as just a power grab by Washington and New York on the top story. I simply knew that New York wanted to control the story. I think New York was simply launching a more centralized control on the news report."

By minimizing journalists' first hand reporting, Interviewee G (Appendix A, 34) says, newspapers and other media were no longer using AP copy as before. "We saw a lot of things, but all of the good stuff in my opinion, all of that personal anecdotal experience, most of it was either buried at the bottom of something or just didn't make the final cut. I don't think that was driven by ideology or politics. That was just driven by a wrong editing attempt to impose a narrative on a story where in the fog of war finding a narrative" is difficult to accomplish. 
Some of the deliberate manipulation or spin, says Interviewee G (Appendix A, 34), was reporting civilian casualties after Afghanistan was invaded. A story by an AP reporter who visited graves where civilians were being buried was "sat on or deemphasized" for a while but eventually published. "Over time, it ultimately became clear that there was some sort of disregard of civilians vis-a-vis their targeting, and it's still an issue as you know," says Interview G.

In the run up to the Iraq war, U.S. administration's strategy was to make its case through the media by amplifying pieces of intelligence selectively and passing them along as anonymous officials and as conclusive proof of Iraq's possession of WMD and ties to al-Qaida. The New York Times led the way in selling the WMD myth (even as UN weapons inspectors in Iraq insisted they had found no evidence of the weapons) and Iraq's links to al-Qaida. ${ }^{9}$

At the AP, pressure on journalists by senior editors to match New York Times “scoops" was very strong despite violating "every internal principle we had," says Kampeas (Appendix A, 11). Ellen Knickmeyer (Appendix A, 12), who was in Iraq in the run up to the invasion, found herself chasing the Times' WMD reports. "The AP may have been cowed not by the administration but by what seemed to be great $N Y T$ exclusives, and because of that went with the prevailing story line of alleged WMD." She adds: "It did not occur to me, really, that both the Bush administration and the New York Times could be completely off-base as they talked of evidence of weapons of mass destruction.... I and some other AP reporters did not do a good job critically examining the Bush administration's stated reason for the invasion. In my time there I 
wound up only going on the Saddam regime's press tours of sites that the U.S. had alleged were WMD sites."

At the same time, the AP was among the first news organizations to expose the nonexistence of WMD and push back against the patriotic narrative, ${ }^{10}$ says Kampeas. In Iraq, AP gave extensive coverage of UN weapons inspectors' search for WMD and their apparent failure to find any real evidence. But the inspectors' reports were delayed and released in New York, reducing their impact, says Labelle (Appendix A, 13). Also, he says, since Iraq sometime blocked the inspectors and regularly criticized their efforts, ${ }^{11}$ the stories about Iraq's handling of the inspectors may have actually given credence to the belief that such weapons did exist. Labelle cites an instance on the international desk "when a reporter was bullied into changing a story that opposed the U.S. viewpoint and cast doubt on the administration's argument that high-strength aluminum tubes obtained by Iraq could be used to develop nuclear weapons. When the New York desk questioned the story and said it lacked balance, the reporter redid it to suggest exactly the opposite, that such tubes could indeed have been intended for nuclear weapons production. ${ }^{12}$ Later, it turned out the tubes had no application in making nuclear weapons and were only used for building standard rockets that Iraq had long possessed." The Iraq Survey Group ${ }^{13}$ in the fall of 2004 concluded in its final report, authored by Charles Duelfer, that there was no evidence that Iraq had a WMD stockpile or program at the time of the invasion. "Baghdad's interest in high-strength, high-specification aluminum tubes dual-use items controlled under Annex 3 of the Ongoing Monitoring and Verification 
Plan as possible centrifuge rotors - is best explained by its efforts to produce $81-\mathrm{mm}$ rockets. ISG conducted numerous interviews related to Iraq's interest in acquiring these tubes - information that regularly pointed toward similar tubes being used in the Nasser-81 ground-to-ground rocket system," the report said. ${ }^{14}$

The media watchdog, FAIR, names four journalists who did not suspend critical judgment in reporting on pre-war weapons claims. Some carried out the basic journalistic tasks of checking facts and holding the powerful to account, according to FAIR's Steve Rendall. ${ }^{15}$ Among the four named was Hanley, who in one story before the war began in March 2003 flatly stated that Iraq had no WMD.

Even before that, Hanley did not take government allegations at face value.

On January 18, 2003, he wrote:

Many of the suspicions raised in the headline-making U.S.-British reports were based on satellite imagery of Iraqi installations, remote photos taken during the inspectors' four-year absence from Iraq. Now that more than $100 \mathrm{UN}$ specialists can again "see under the roofs," as Perricos put it, the alarms look less warranted.

American intelligence analysts, for example, wrote that new structures photographed at Tuwaitha, a former nuclear weapons complex south of Baghdad, might indicate a revival of weapons work. Since Dec. 4, however, inspectors from ElBaradei's International Atomic Energy Agency (IAEA) have scrutinized that vast complex almost a dozen times, and reported no violations. ${ }^{16}$

Hanley (Appendix A, 8) explains in the interview the challenges he and others faced in investigating the Iraq weapons story.

Much can be said, but one factor, I'm sure, was simply a lack of expertise in the media in the subject of WMD, an inability to look at the more detailed allegations and understand them and see through them.... 
My copy was repeatedly spiked without any consultation. It seemed the narrative in Washington became so overwhelming that anything that didn't fit into that narrative simply seemed too odd, too much of an outlier to put on the wire. One other point, among many: There was an attitude in the Washington media, which I heard, that it didn't matter, that they weren't interested in digging into this WMD stuff because the powers that be are bent on war and we shouldn't waste our time on this, when we should be spending our time on preparing to cover the war (lining up embeds, equipment etc.). I'll say flatly that writers were not under any pressure to demonstrate patriotism or avoid being critical, skeptical. I had stories killed without any discussion. So there wasn't active 'pressure,' just the pressure of seeing stories spiked, which might lead some to avoid doing such stories, but not in my case.

Nor were the media, says Hanley, afraid to report "atrocities and other negative stories about U.S. military operations in Afghanistan and, later, Iraq." (I will examine this later in the chapter.)

In my case, with Iraq, my reporting ran contrary to the line coming out of the administration in Washington. I'm not specifically aware of pressure on 'senior editors' from higher-ups, government, U.S. military etc. in relation to post-9/11 coverage. But of course that kind of pressure is omnipresent in the news business, i.e., government officials, lobbyists et al. complaining about stories, or doing the opposite, i.e., pushing certain stories."

Pressures were not direct - no phone calls or discussions - says Hanley, except for a few times. "There was direct pressure that I resisted, pressure to try to match Judy Miller's fallacious NYTimes stories about the presence of WMD, early in the invasion period. There was another example or two, an effort to keep me from reporting on civilian casualties south of Baghdad as the invasion period was winding down, but again I resisted, did the reporting and got the story."17 
One complaint conservative newspaper publishers had of the AP, says Interviewee B (Appendix A, 29), was that it was not reporting good news from Iraq in the war's aftermath.

The Bush administration was touting its rebuilding efforts and moves to help Iraq have Democratic elections. Reporters on the ground and their AP editors knew better - i.e. that the country was becoming more dangerous and divided post war. So yes there was a 'consensus' among many U.S. newspaper leaders that backed the Bush White House, but I think AP maintained its objectivity for the most part despite pressures from time to time to look for more 'good news stories' out of Iraq.

In Iraq, reporters' own self-censorship came in various forms: avoiding critical reporting of the actions of U.S. troops, dismissing or ignoring - especially in the early days and months of the war - reports that indicated misconduct by soldiers, sometime taking military officials' words at face value despite the inaccurate information they had provided regarding Iraq's WMD possession. Even when reporters were willing to go the extra mile to investigate American atrocities, they often had to tread carefully with the kind of "balance" that often tilted in favor of the military. One example was the U.S. aerial bombing of a wedding party ${ }^{18}$ in May 2004 that killed up to 45 people, mostly women and children from the Bou Fahad tribe in Mogr el-Deeb, a desert village on the Syrian border. The U.S. military insisted the target was a suspected safe-house for foreign fighters from Syria. In a statement, the U.S. Central Command said coalition forces conducted a military operation at 3 a.m. against a "suspected foreign fighter safe house" in the open desert. The coalition troops came under hostile fire and "close air support was provided," the statement said. The troops recovered 
weapons, Iraqi and Syrian currency, some passports and some satellite communications gear, it said. ${ }^{19}$

Over the next few days, photographer Anja Niedringhaus and I were able to gather evidence - including video footage from the wedding that confirmed the attack was indeed on a wedding party and the victims were overwhelmingly women and children. ${ }^{20}$ We interviewed more than a dozen survivors a day after the bombing and were able to identify many of them on the wedding party video - which ran for several hours. Also, the day after the attack, AP television (APTN) traveled to Mogr el-Deeb to videotape the wedding site: a devastated building and remnants of a tent, pots and pans, pieces of what appeared to be remnants of ordnance, one of which bore the marking "ATU-35," similar to those on U.S. bombs. Another tape, recorded a day later in the town of Ramadi - where the dead were buried and the injured hospitalized - showed Hussein al-Ali, a popular Baghdad wedding singer hired for the festivities, lying dead in a burial shroud - his face clearly visible and wearing the same tan shirt he wore seen performing in the earlier wedding video. His brother, a stocky man with close-cropped hair, played an electric organ. ${ }^{21}$

The army approached the AP several times asking for the video of the actual wedding that I had obtained from the survivors. A few days after the attack, a dozen U.S. soldiers came to the AP offices at the Palestine Hotel in Baghdad for the video. As they headed to the newsroom, Niedringhaus ran to the APTN office which was at the other end of the long corridor, took the tapes and hid in the bathroom. The AP news editor, who was apparently willing to hand the soldiers the tapes, told them 
Niedringhaus had them. Failing to find her, the soldiers left. But the army kept up the pressure. When it eventually admitted that it might have been a wedding attack, it still insisted that foreign fighters were killed, and at one point spokesman Brig. Gen. Mark Kimmitt made the remarkable claim that "bad people have celebrations, too. Bad people have parties too." 22 Niedringhaus and I kept the story alive for almost a week with evidence after evidence that the attack was indeed on a civilian wedding party. The army persisted in its denial. ${ }^{23}$ At a daily briefing the army produced "Sudanese passports" to prove they were foreign fighters. Foreign journalists, with little knowledge of Arabic, failed to notice that the so-called "passports" were in fact driving licenses, as apparent in their reporting at face-value Kimmitt's comments. ${ }^{24}$ After nearly a week, the AP began softening the story. ${ }^{25}$ For example, the lead of an AP story dated May 23, 2005, began with Kimmitt's charges and only referred to AP's own finding lower in the copy. "The U.S. military said Saturday it has found "no evidence of a wedding" at the site of an airstrike last week near the Syrian border, and said evidence so far suggested the target was a desert base for foreign terrorists sneaking into Iraq," the story said. It said Kimmitt "showed slides of military binoculars, guns and battery packs that could be used to trigger roadside bombs found by U.S. troops at the site. He said 'terrorist manuals,' telephone numbers for Afghanistan and foreign passports, including one Sudanese, were also recovered there."

In a May 26 email, I complained to then foreign editor Deborah Seward about the drastic edit of my story ${ }^{26}$ that "sounded like we were refuting everything we've 
been saying for the past five days." The second paragraph of the edited story was the most disturbing, I wrote to Seward: it used an irrelevant quote from the musician's widow to make the story look balanced. ("The military presented its case at a news conference while elsewhere in the capital, the widow of a popular Baghdad wedding singer who was among up to 45 people killed in Wednesday's attack said "he was an example of beauty.") For the sake of accuracy, I wrote to Seward, I had tried the previous week to be very meticulous in getting details, matching them against other details, spoke to dozens of witnesses, relatives and victims. I even drew up a list of the names of those who were killed and injured, their ages, etc. I saw a seriously injured baby, spoke to an injured teenaged girl and four women in the hospital. I said my story was supposed to be about the man - the musician seen in the film playing his organ and whose body was later filmed in a cemetery in Ramadi - the most crucial evidence that it was indeed a wedding party that was attacked. Yet the edited story had 14 paragraphs of Kimmitt's comments, and only gave the Iraqis' side of the story in paragraph 15. In her reply, Seward assured me that "nobody deliberately distorted the copy. Your points are well taken and we'll look at the copy." There was, however, no further discussion of the matter. Niedringhaus (Appendix A, 19) also had problems filing photos of the dead Iraqis at the wedding. When she sent the pictures, London Photos declined to use them, saying they were "raw hamburgers," and only used them after she threatened to resign. ${ }^{27}$

As atrocious as acts committed by U.S. soldiers may have been, the media often amplify emotional and psychological reasons that could drive American soldiers 
to extreme behaviors: They believed they were under fire, or they responded to defend themselves, as shown below. While this may be true, responsibility is thus diminished. When soldiers reacted to the blowing up of an electrical transformer that plunged a Baghdad neighborhood into total darkness (August 2003), killing six innocent Iraqi civilians in a matter of 45 minutes, the AP story told readers that the Americans were fearing an attack, or as in one AP report, because they were "confronted by daily guerrilla attacks that have claimed 56 American lives since May 1 (2003), U.S. troops are on edge." ${ }^{28}$ In other words, they did not mean to kill, therefore, they should not be judged as deviant and killers. Their action almost never reflects on the military. Even those who are deemed deviant are portrayed as special cases. On the other hand, if an Iraqi goes on a killing spree against American troops, attempts are rarely made - if at all - to explain why he may have done so, to explore whether it was revenge for the death of a loved one by a U.S. soldier, or if he opposed the illegal U.S. occupation of his country. On the contrary, this Iraqi often comes to represent the general Iraqi population, is labeled a terrorist, generally a reference to Islamic extremists sympathetic to al-Qaida - even if he is not. As were the two innocent young men who were killed by U.S. soldiers when the Baghdad neighborhood went dark. Without evidence, the military accused them of being terrorists and imprisoned two surviving friends. ${ }^{29}$ Reporters duly inserted this label in their story (even though they were aware the victims were innocent), fulfilling the journalistic requirement of giving balance, and by doing so they likely planted suspicion in the readers' mind: maybe they were not so innocent after all. The media 
succeeded in dehumanizing the Iraqis, just as they dehumanized the Vietnamese decades earlier. ${ }^{30}$ They moved away from the real story, the murder of two innocent Iraqi youths, who were no longer seen as victims but potential perpetrators and their deaths perhaps unavoidable. For example, the lead of a 334-word AP story from Baghdad on Feb. 28, 2008, ${ }^{31}$ said: "U.S. soldiers killed an Iraqi civilian who raised suspicion and failed to heed warnings to stop as he approached their foot patrol north of Baghdad, the military said Thursday." The following paragraph: "The man was wearing a bulky jacket and had his hands in his pockets Wednesday as he walked toward the troops in the area around Muqdadiyah, about 60 miles north of Baghdad, according to a statement." Third paragraph: "U.S. troops issued warnings for the man to stop, then killed him when he failed to heed them, the military said, adding no weapon was found when the man was searched. No U.S. troops were wounded in the incident, which was under investigation." Only in the fourth paragraph - instead of the first - do we learn that the "slain man was elderly and suffered from mental disabilities and hearing problems."

In 2005, I transferred from Iraq to Morocco to report on "terrorism" in Europe and North Africa. In May 2006, I was assigned an in-depth project on why ordinary mainstream Muslims in Europe were silent in the face of attacks in Madrid (2004 train bombings), Amsterdam (2004) and London (2005 transit suicide bombings). ${ }^{32}$ I began my investigation by putting the question to a couple of leading European scholars of Islam, Olivier Roy and Rudd Peters, who found fault with the premise of the story - as I had told the editor (Appendix C, 1) when he requested the project. In 
the 1970s, said Roy, when the communist and anti-imperialist Baader Meinhof carried out bombings in the name of the proletariat, workers did not demonstrate against the group because they had nothing to do with the bombers, why then should Europe's Muslims - who originate from 57 countries, differ in culture, language and even the strain of Islam they follow - speak out against, or apologize for actions of radicals who do not represent them? Roy said (Appendix C, 2) it was a mistake to look at Muslims in Europe as a community and expect them to react as a community as apparently Western media often do. All the more than five dozen Muslims interviewed in Amsterdam, Paris and London, agreed with Roy's assessment. However, the AP editor wanted a more condemnatory piece about Muslims when he saw my finished story. ${ }^{33}$ An exchange of internal AP private messages over a couple of days between myself and the editor in London ensued before the story was finally published. The exchange, a document that I have kept in my files (Appendix C, 1), highlights the battle some journalists had to fight in pursuit of reporting facts that may have gone against the narrative senior AP editors had in mind when assigning a project like this (Appendix C, 3).

"We need a bit more balance," the editor wrote to me in the private message (Appendix C, 1). "You make the good point (as we discussed earlier) that most Muslims feel no obligation to speak out against terrorism. ... Could you get an expert to express the European point of view of: 'Why aren't Muslims speaking up?'As we discussed, more vocal expressions of revulsion against the attacks in the media or in protests could work to mainstream Muslim's advantage - showing the West that there 
is, much more to Islam than violent radicalism. You might want to mention Hirsi $\mathrm{Ali}^{34}$ - an exception to the rule. Without being as "in-your-face" and anti-Islam as Hirsi Ali, why aren't there more courageous voices like hers saying 'enough is enough! the terrorists distort Islam. This is wrong!'” In other words, he did not want only independent and experienced analysts, but the kind that would provide inflammatory balance to the actual situation on the ground.

I explained that everyone I had spoken to - including those with strong antiMuslim views - had said Muslim leaders were the ones who were expected to condemn the attacks, not ordinary people and that I had only found one woman writer on the Internet who demanded that average Muslim people should do so. The rest, I wrote, were bloggers, and asked the editor if he wanted me to use their viewpoints. I had even mentioned Hirsi Ali’s position to Roy and Rudd who said it was wrong to link the two together.

But the AP editor persisted: "Sharpen up a bit the argument of those who think there should be unequivocal repudiation given how much of the terrorism is Islamic and how many of the radicals seem to take it upon themselves to speak for Islam." It was clear what the AP wanted: to reconfirm the stereotype narrative of Muslims as innately violent-spirited. All they needed from me was to fill in the blanks and provide quotes and opinions that reaffirmed this bias. I decided to see how far the editor would go with this, so I told him I would look for an "anti-Muslim" expert to provide the "balance" he was seeking. The following day, I informed him that I was trying to interview an Israeli professor in London with strong views against Muslims, to which he responded, "great." 
I had to settle for an Irish professor at King's College in London - also fiercely antiMuslim - when the Israeli academic was unavailable. John Thorne (Appendix C, 4), a journalist colleague in Rabat, put me in touch with Rory Miller, who began the interview by accusing the whole Muslim population of Europe of supporting terrorism because of their silence toward attacks, and said Muslims were innately pro-violence in their cause. ${ }^{35}$ After probing him with questions like: What exactly were mainstream European Muslims supposed to do, Miller responded: "They have to be law-abiding citizens." Did he have any reason to believe they were not law abiding? "No," he said. His argument began to fall apart and in the end he said angrily: "Listen, John [Thorne] said you wanted my help, this is what I think." I repeated my question: What do you expect Muslims do? He replied: “Maybe you should focus your story on why Muslims don't criticize their leaders!" I had no radical quote to use in my story. The editor came with another idea to bring "balance" to the story. There have been polls, he said, "showing a significant minority supporting suicide bombings in Israel, and prominent figures who have spoken out have been intimidated. Think it should be fairly straightforward to weave in." I objected to the new line for a story whose focus was mainstream European Muslims reacting to attacks in Europe. He was demanding the use of the T-word, that makes Muslims come across as complicit in the bombings no matter where. He was apparently following a peculiar American - even Western - practice of laying collective guilt on all Muslims $^{36}$ for suicide bombers throughout the world. The story was about bombings and attacks in Europe, in their own countries - where they immigrated and were born. But their feelings about bombings in Israel, I wrote to the editor, was moving away from the 
topic of my story. How about then asking them for their thoughts about bombings in Iraq, Afghanistan or Indonesia? But the editor was adamant in his request at any cost. "The polls show there is support for terrorism (e.g. 30 percent support for suicide bombers in Israel, a significant number expressing sympathy for attacks in Europe).... Support for suicide bombings in Israel is a clear indication that some people living here have been radicalized and I remember there being other polls that show sympathy for the terrorists in Europe," the editor wrote.

It was hard to even find the mentioned poll. The only one I could find that quoted the 30 percent was on a site of pro-Israel Daniel Pipes, headlined, "More Survey Research from a British Islamist Hell," ${ }^{37}$ with a link to Populus ${ }^{38}$ poll of 500 British Muslims conducted for a coalition of Jewish community groups from December 9-19, 2005. According to this poll, 30 percent said the state of Israel has no right to exist, while 53 percent said it had; 16 percent believed that suicide bombings in Israel can be justified.

But that was not the point and the editor and I both knew it. It was clear the AP only wanted me to provide quotes and opinions that fit the narrative. I refused and threatened to go to higher ups in New York. The editor backed down, finally telling me by telephone that he agreed with me and that he was under pressure from the top editor in London. ${ }^{39}$

The above example sheds light on source selection and basing a story on a predetermined storyline. The effect of 9/11 on media coverage is clearly evident here, where the attempt to equate Islam with terrorism and extremism is almost too blunt. 
Another instance of selective sourcing and value-loaded language was evident in a series of stories about an incident in March 2007, when the AP, without skepticism or challenge, accepted claims by British and American officials that "Naval forces of Iran's hardline Revolutionary Guards seized 15 British sailors and marines at gunpoint in Iraqi waters of the Persian Gulf." ${ }^{40}$ In value-laden language, it added in the same paragraph: "The provocative move comes during heightened tension between the West and Iran" even though the circumstances surrounding the incident were not clear yet. In the second paragraph, the story quotes state Iranian television as saying: "Iran insisted the British service members were seized because they had entered Iranian territory and were held 'for further investigation." Citing Iran's side of the story appeared no more than an attempt at "balance" since the AP had already judged the seizure as "provocative." The U.S. and British officials said the incident had occurred near the disputed Shatt al-Arab waterway, which flows between the two countries and empties in the Persian Gulf. But when a year later, British Defense Ministry documents ${ }^{41}$ revealed that the Britons were actually seized in internationally disputed waters, the media were no longer interested, even though the documents controversially explained that the incident occurred because the U.S.-led coalition designated a sea boundary for Iran's territorial waters without telling the Iranians where it was.

Still, these examples do not mean that there was a centrally-organized conspiracy at the AP to mislead or favor one side or the other ${ }^{42}$ as former AP's Jacqueline L. Hazelton (Appendix A, 9) explains. "Editors' behavior was generally more about what each individual believed higher-up editors wanted than it was about what higher-ups said 
they wanted." (Although in the case of Europe's "Silent Muslims," it was pressure from the top editor to conform to the narrative.) "This made it difficult for higher-ups to institute changes in editors' behavior as AP tried to change with the changing news environment (e.g., address the growth of cable news and the Internet)," she says in an interview for this thesis. On the print side, she adds, coverage directions were "always based on perceived news values rather than external pressure."

America's "war on terror" involved open and covert military operations and new security and finance legislations. ${ }^{43}$ Many states joined the campaign, using it as a pretext to clamp down on legitimate protest and freedom. ${ }^{44}$ Former Israeli military spokesman, Shai Nachman, admitted to British researchers ${ }^{45}$ that $9 / 11$ made it easier for his country to use the terrorism argument in its wars against Palestinians and Lebanese. "They made a strategic decision to turn all of the public relation over towards the war on terror. They already had quite a lot of good publicity going for them ... it wasn't that much different in terms of the exclusion of Palestinian perspectives or Arab perspectives before and after 9/11, but nonetheless it did give the Israelis a huge extra card to play and they played it very well, probably more in America than they did here [Europe]," 46 Greg Philo (Appendix A, 21), one of the researchers who interviewed Nachman, told me.

Many academics hoped that $9 / 11$ would provide the media with an opportunity to redeem itself as a new sense of purpose swept newspapers and newscasts after years of "frivolous" 47 journalism that had turned into celebrity entertainment. Most importantly, Jay Rosen, ${ }^{48}$ among other critics of media budget cuts, hoped for the return of quality foreign news. Such an opportunity did present itself immediately after the attacks. One of 
the first debates that questioned why America was hated abroad took place in a town-hall format conducted by ABC's Peter Jennings. There was unprecedented public interest to learn Arabic and even read the Quran. ${ }^{49}$ However, this curiosity was short-lived as the war propaganda began. Revenge was sought and the media parroted the words of the president and his hawkish administration. Americans heard about the Muslim monster jealous of their civilization, culture and values. Post- 9/11 took the media's dehumanization and demonization of Muslims and Arabs to new levels. ${ }^{50}$ While the Cold War was framed as a struggle against communism in the Western media, the "war on terror" that followed 9/11 was justified and legitimized as protecting the free and democratic world from Islamic "terrorists." Both wars stem from a system of domination; the difference between them was how they were justified and legitimated. ${ }^{51}$

Rosen, an academic, laid the largest portion of blame for Americans' lack of understanding of international news and informing them why America was hated around the world - a question that Americans only started asking and debating rather belatedly and only after $9 / 11$ - on corporate media for pulling out foreign correspondents and closing down a large number of overseas bureaus to cut cost. The media's justification was that American viewers were not interested in international news. ${ }^{52}$

However, prior to $9 / 11$ and despite overall budget cuts, there were still plenty of American journalists based in the Middle East - including reporters from the New York Times, the Washington Post and other major American newspapers, as well as The Associated Press and CNN - whose bureaus remained open and staff members were not noticeably slashed. All the major American TV networks also had bureaus in Israel, the 
source of present-day anti-American anger because of its strong support for Israel. While Israel has been at the core of Arab and Muslim anger/hatred of America for decades, Iraq became another cause after its invasion. Also, the majority of people in the Middle East and beyond accuse Washington of backing repressive Arab rulers, such as in Saudi Arabia - that mainstream media - duly and misleadingly - refer to as moderates because they are U.S. allies. ${ }^{53}$

Those news organizations that were present in the Middle East before 9/11 did not sound the alarm to the growing anti-American sentiments. Occasionally in features or analyses they may have touched on some of the deeper issues, ${ }^{54}$ but in their routine dispatches, they failed to put the events into context, or, for example, to tell Americans in so many words that Israel's occupation of Palestinian lands and its brutal treatment of civilians, as well as America's unwavering support of Israel were behind much of the gradual rise of the so-called Islamic radicalism. They did not tell their audiences that U.S. veto after veto of UN Security Council resolutions ${ }^{55}$ condemning Israeli atrocities had created a disturbing Arab resentment of America. ${ }^{56}$ Instead, they often painted the Israelis as the victims, subjected to savage missile and suicide attacks by Palestinian "terrorists," not explaining that their actions could have been in response to Israel's occupation of their lands, to the expansion of illegal Jewish settlements, (and more recently to the high cement walls that cut through their villages and fields, or to the total blockade of Gaza). ${ }^{57}$

Even when some reporters tried to address those issues after 9/11 - they faced “censorship" by editors. "Hatred of America built up over the years as Washington killed one UN Security Council resolution after another condemning Israel for its actions 
against the Palestinians, ${ }^{, 58}$ was the lead of a Cairo-edited AP story from Amman, Jordan in 2004. However, an editor in New York replaced the lead, without context, with an inflammatory quote from a Palestinian journalist: "Mohammed Domeh was relaxing on his living room sofa, watching the TV news when he heard the fateful words: President Bush was flatly ruling out the return of Palestinians such as himself to what is now Israel. 'When I heard what Bush had to say - and I am saying this as a Palestinian intellectual - I wished I could wear an explosive belt around my waist and blow myself up in front of Bush," said Domeh, 44." The reference to Domeh in the original copy that gave context to the quote was entirely taken out in the New York-edited version: he had said while he could never be a suicide bomber, Bush's words made him understand a bomber's motive due to Israel's policies against Palestinians. With the stroke of a pen, the AP editor in New York turned the Palestinian journalist in Amman into a villain, the "bad guy." It is important to note that the story had already been edited by the Middle East news editor in Cairo but not moved on the open wire. This kind of editing had become frequent and in my experience journalists were accustomed to it, causing them to exercise a form of selfcensorship, i.e. refrain from making a case that would remotely justify Arab anger and explain their subsequent actions. Rosen may be right in principle, but in practice, the availability of foreign correspondents overseas did not always enlighten or educate the American public to the reality on the ground.

Israel's PR drive may have played a role in the editing process of a June 10, 1996 AP feature ${ }^{59}$ from the Jewish settlement of Tekoa in the Israeli-occupied West Bank. The lead was altered ${ }^{60}$ to read: "Get a rabbi committed to settling Jews throughout the West 
Bank together with a sheik whose organization is responsible for the murders of dozens of Jews and what do you have? 'Chemistry,' says Rabbi Menachem Fruman, who met with Sheik Ahmed Yassin last week." The original, a copy of which I do not have, was a straight forward interview with the rabbi who spoke of his empathy for Yassin whom he had visited in jail. For this thesis, Ron Kampeas (Appendix A, 11), the editor in Jerusalem who had changed the lead, was asked if the balance was not unfairly in favor of the rabbi, and that the reference to Yassin as a murderer was inflammatory. "I guess I was going for the colorful balance," explained Kampeas. "On the other hand, Fruman was a true peacenik ... and although he was a settler by virtue of being someone who lived in a settlement, he was not a formal part of the movement. ... He ended up shunned to a degree. He was certainly not a part of the settler movement offshoots that were murderous - like the terrorist underground in the 1980s. Yassin, on the other hand, was a founder of Hamas." It is worth noting, however, that Hamas is a Palestinian group whose formation in the late 1980s was not only encouraged by Israel as a counter to the secular PLO, but was also respected by a large number of Palestinians as a resistance movement against Israel's occupation and siege of Gaza. Deadly suicide bombings in Israel by Hamas followed Israel's January 5, 1996 assassination of one of its top fighters, Yahya Ayyash, dubbed by mainstream Western media the bomb maker. ${ }^{61}$

Anti-U.S. attacks, such as on the World Trade Center in New York in 1993, U.S. embassies in Kenya and Tanzania in 1998, or USS Cole in Yemen in 2000, "did not prod the media to pay serious attention to examining the chance of terrorism on U.S. soil," said Waisbord. ${ }^{62}$ Even earlier, when the Cold War mentality pervaded the media, the public 
were not warned of the rise of dangerous guerrilla groups the Americans had trained and financed to fight the Soviet occupiers of Afghanistan in the $1980 \mathrm{~s} ;{ }^{63}$ nor did they later alert the public that these former guerrillas had turned against America for building increasing number of bases in the region, transforming it into a militarized zone. ${ }^{64}$ During the 1991 Gulf War, mainstream U.S. media were preoccupied with staying close to the military and their daily briefings, and failed to provide the big picture of the region's changing political dynamics and imminent threats from these extremist groups. Even earlier, a string of attacks against American targets in the 1980s - including the 1983 bombing of the American Embassy in Kuwait, two months after the U.S. Marines bombings in Beirut ${ }^{65}$ - did little to jolt the media. Journalists, however, largely chose to fill their reports with describing attackers as "crazed Islamist terrorists who hated Western democracy,"66 as though they had sprung out of nowhere. Even Waisbord could not resist this kind of evaluation:

Islamic fundamentalists showed nothing but contempt for the principles of democratic journalism. Mullah Omar's offer of money for the murder of Western journalists and the brutal murder of Wall Street Journal journalist Daniel Pearl patently attested to the visceral opposition of fundamentalist Islam to the U.S. media. It was even speculated that alQaida wanted to attack the media because it embod[ied] both freedom and excess. ${ }^{67}$

Waisbord ignored the fact that al-Qaida and its leader, Osama bin Laden, invited Western journalists on several occasions to his hideouts in Afghanistan, using them to propagate his messages. ${ }^{68}$ Before 9/11, the Taliban, whose leader is Mullah Omar, had a press office in Washington and a spokesman appeared regularly on American TV networks. Meanwhile, it was the Americans who bombed Western journalists in Iraq, 
killing three and wounding four in the early days of the Iraq invasion. ${ }^{69}$ The Taliban were not behind 9/11 and the Taliban are not al-Qaida and had not attacked any American institutions before. ${ }^{70}$ Pearl's killing occurred after the American invasion of Afghanistan. Also, the public was not told repeatedly - as they are told about the "bad guy" Muslims that the Afghan Taliban and Arab fighters were armed and financed by the U.S. only 20 years earlier to fight the Soviets in Afghanistan. Some of the Arab fighters later came to be known as al-Qaida. This crucial information was rarely mentioned in the mainstream media's daily reports out of the war zones..$^{71}$ This kind of journalism, according to academic Robert W. McChesney, ${ }^{72}$ "is more likely to produce confusion, cynicism, and apathy than understanding and informed action. Hence one of the paradoxes of professional journalism: it is arguably better at generating ignorance and apathy than informed and passionately engaged citizens." During the 2008-9 Israeli bombardment of Gaza, I was impressed that National Public Radio interviewed knowledgeable experts who credibly provided in-depth analyses of the conflict, refuted with evidence Israeli assertions that Hamas had violated the ceasefire sparking Israel's "retaliation." However, such crucial information was routinely omitted from the newscasts on top of the hour that listeners largely tune into - almost certainly leading to similar confusion to which McChesney refers.

In a pre-conflict phase, a process of demonization occurs by the discursive creation of a victim - Afghan and later Iraqi people were positioned as the victims of the brutal Taliban and Saddam Hussein. "Through this re-articulation, the signifier 'people' is incorporated into the realm of the Anglo-American Self that constitutes its protectors." $" 73$ 
The coalition waging the war against dictators is positioned as the "heroic safeguards of world security." At the same time, the American (and other Western) people are potential victims of Taliban/al-Qaida/Saddam - in Iraq's case, because of his potential use of weapons of mass destruction and supposed support for terrorist networks. Western powers, as generally reflected in the media, legitimize the use of violence to protect their people, but only as a last resort and out of necessity, while presenting themselves as liberators of the Afghan and Iraqi people. ${ }^{74}$ This narrative excludes the destructions in the two countries and loss of human lives, the latter often referred to by Western governments as "accidental" or "collateral damage." This process of "heroization" 75 is highlighted in the mastery of superior technology and weaponry that the "savior" soldiers use to avoid civilian deaths. At the same time, the "evilness"76 of the enemy is emphasized as a threat to humanity. "The Self's goodness emanates not only from the willingness to fight this evilness, but also on the attempts to rescue the victim. These three discursive positions - Self, enemy and victim - together form the core structure of the ideological model of war." ${ }^{.77}$ When the wars erupted, as in the 1991 war against Iraq, the American public was "seduced" into a "computer-game culture of smart bomb photography and instant drama," $" 78$ leaving some observers to question the media's complicity in misinforming Americans. Howard Tumber, an academic, maintains that only rich and militarily high-tech nations - the U.S. and the NATO alliance - can wage this form of "Information War," that does not require the mobilization of weaponry, especially missiles and aircraft, and there is little need for the wider populace to be engaged in their efforts. ${ }^{79}$ 


\section{Endnotes}

${ }^{1}$ George W. Bush, Address to a Joint Session of Congress and the American People, September 2001. http://georgewbush-whitehouse.archives.gov/news/releases/2001/09/20010920-8.html

${ }^{2}$ Report of the Defense Science Board Task Force on Strategic Communication, September 2004, Office of the Under Secretary of Defense For Acquisition, Technology, and Logistics. http://www.fas.org/irp/agency/ dod/dsb/commun.pdf

3 Silvio Waisbord, "Journalism, Risk and Patriotism," in Barbie Zelizer and Stuart Allan (ed.), Journalism After September 11 (New York: Rutledge, 2002).

4 ibid p. 202.

5 ibid. pp. 208-9.

6 Daniel Okrent, New York Times, “THE PUBLIC EDITOR; Weapons of Mass Destruction? Or Mass Distraction?" May 30, 2004. http://www.nytimes.com/2004/05/30/weekinreview/the-public-editor-weapons-ofmass-destruction-or-mass-distraction.html

${ }^{7}$ AP published in The Observer, "Powell Calls for United Nations to Watch Iraq," Feb. 6, 2003. http:// www.archives.nd.edu/Observer/2003-02-06_v37 089.pdf

${ }^{8}$ The Guardian, "Full text of Tony Blair's foreword to the dossier on Iraq," Sept. 24, 2002. http://www.theguardian.com/world/2002/sep/24/iraq.speeches

${ }^{9}$ For a collection of stories, see Media Matters For America. http://mediamatters.org/tags/prewar-intelligencewmd? $\mathrm{p}=2 \& \mathrm{~s}=15$

${ }^{10}$ Charles J. Hanley, AP published on casi.org.uk, Jan. 18, 2003. http://www.casi.org.uk/discuss/2003/msg00276.html. See also, Steve Rendall, Fairness \& Accuracy in Reporting (Fair), April 1, 2006, http:// fair.org/extra-online-articles/wrong-on-iraq-not-everyone/

11 See for example, Ellen Knickmeyer, AP published in Free Republic, "Iraq Warns UN Weapons Inspectors," Oct. 12, 2002. http://www.freerepublic.com/focus/f-news/768016/posts

12 George Jahn, Associated Press archives, “Officials: Tubing may have Iraq link," Sep. 18, 2002. http:// www.apnewsarchive.com/2002/Officials-Tubing-May-Have-Iraq-Link/id-77ece27e01da699ca7ea4db69245d5de?SearchText=george $\% 20$ jahn $\% 20$ Iraq\%20aluminum\%20tubes\%202002;Display

13 Iraq Survey Group Final Report, Global Security, 2004. http://www.globalsecurity.org/wmd/library/report/2004/isg-final-report/isg-final-report_vol2_nuclear-05.htm

14 ibid. 
15 Rendall, op cit.

16 Charles J. Hanley, AP published on casi.org.uk, Jan. 18, 2003. http://www.casi.org.uk/discuss/2003/msg00276.html

17 Niko Price, AP published in The St. Augustine Record, June 11, 2003. http://staugustine.com/stories/ 061103/ira 1597751.shtml. See also: Charles J. Hanley, AP published on truth.out.org, "Activists Confirm Iraqi Hospital Bombed," March 13, 2003. http://www.truth-out.org/archive/component/k2/item/43928

18 Scheherezade Faramarzi, AP published in Fredericksburg.com, May 20, 2004, "U.S. Aircraft Reportedly Kills 40 Iraqis" -http://www.fpp.co.uk/online/04/05/Iraq_wedding_massacre.html

19 ibid.

20 Scheherezade Faramarzi, AP published on Boston Globe.com, May 21, 2004,"'Iraqi survivors recount US tent shelling after wedding party"- http://www.boston.com/news/world/middleeast/articles/2004/05/21/ iraqi_survivors_recount_us tent_shelling_after_wedding_party/

21 Scheherezade Faramarzi, AP published on Commondreams.org, May 24, 2004, "Video Contradicts US Military, Shows Iraq Wedding Celebration" - http://www.commondreams.org/headlines04/0524-02.htm

22 CNN, “U.S.: No evidence of wedding at attack site," May 22, 2004. http://www.ar15.com/archive/topic.html? $\mathrm{b}=1 \& \mathrm{f}=5 \& \mathrm{t}=245324$

23 Rudi Williams, American Forces Press Service, "No Wedding Party, Children's Deaths Indicated, Military Spokesman Says," May 22, 2004. http://www.defense.gov/news/newsarticle.aspx?id=26427

${ }^{24}$ CNN, "U.S.: No evidence of wedding at attack site," May 22, 2004. http://www.ar15.com/archive/topic.html? $\mathrm{b}=1 \& \mathrm{f}=5 \& \mathrm{t}=245324$; also see: Dexter Filkins, New York Times, "U.S. Says It Has Arms From Site of Attack," May 23, 2004. http://www.nytimes.com/2004/05/23/international/middleeast/23LINE.html

25 Anthony Deutsch, AP published in Spartanburg Herald-Journal, "No wedding at border, says military: Evidence: Military binoculars, guns and passports," May 23, 2004. http://news.google.com/newspapers? $\underline{\text { nid }=1876 \& \text { dat }=20040523 \& \mathrm{id}=\text { zZ0fAAAAIBAJ\&sjid=ZNAEAAAAIBAJ\&pg }=6847,3233021}$

26 Scheherezade Faramarzi, AP published in Laredo Morning Times, May 25, 2004, "Photos may show U.S. attacked safe house, not wedding" - http://airwolf.lmtonline.com/news/archive/052504/pagea8.pdf

27 Anja Niedringhaus. Skype interview. Feb. 3, 2013.

28 Scheherezade Faramarzi, AP published Jacksonville.com, "Jittery U.S. soldiers firing in the dark kill six Iraqis trying to get home before curfew," August 10, 2003.http://jacksonville.com/tu-online/apnews/stories/ 081003/D7SR8BVG5.html

${ }^{29}$ Scheherezade Faramarzi, AP archives, "Iraqi criss-crosses country looking for son swallowed up in U.S. detention system, Dec. 17, 2003. http://www.highbeam.com/doc/1P1-88680988.html 
30 Daniel C Hallin, The "Uncensored War": The Media and Vietnam (California: University of California Press, 1989).

31 Kim Gamel, Associated Press, AP published in USA Today, Feb. 28, 2008, "US mil: Iraqi killed north of Baghdad" - http://usatoday30.usatoday.com/news/world/2008-02-28-1394763717_x.htm

32 Dutch filmmaker Theo van Gogh was assassinated on Nov. 2, 2004 by a Dutch-Moroccan Muslim apparently for his work with the Somali-born writer and politician Ayaan Hirsi Ali to produce a short TV film called Submission that was critical of Islam. http://usatoday30.usatoday.com/life/people/2004-11-02-vangogh-murder_x.htm

33 Scheherezade Faramarzi, AP archives, "Muslims address silence on Europe attacks, Jun. 24, 2006. http:// www.apnewsarchive.com/2006/Muslims-Address-Silence-on-Europe-Attacks/iddad282d986d9219f4a2b08afc26764a4?SearchText=scheherezade $\% 20$ faramarzi $\% 20$ silent $\% 20$ muslims \%20amsterdam\%202006; Display

34 Ayaan Hirsi Ali is a controversial Somali-born writer and politician known for her provocative attacks on Islam.

${ }^{35}$ I have a tape and transcript of the interview.

36 Amna Akbar, The Nation, "How Tarek Mehanna Went to Prison for a Thought Crime," Dec. 31, 2013. http://www.thenation.com/article/177750/how-tarek-mehanna-went-prison-thought-crime

37 Daniel Pipes, Daniel Pipes Forum, “More Survey Research from a British Islamist Hell,” Jul 26, 2005. http://www.danielpipes.org/blog/2005/07/more-survey-research-from-a-british-islamist

38 Populus, "Muslim Poll,” Dec. 9-19, 2005. http://www.populus.co.uk/the-times-muslim-poll-191205.html

${ }^{39}$ Recording of the conversation is unavailable.

40 Jim Krane, AP published in The St. Augustine Record, AP, March 24, 2007, "Iranian forces seize 15 U.K. sailors, marines," http://staugustine.com/stories/032407/world 4489119.shtml

${ }^{41}$ Dominic Kennedy, The Times, "Report reveals Iran seized British sailors in disputed waters," April 17, 2008. http://www.thetimes.co.uk/tto/news/politics/article2025032.ece

42 Karim H. Karim, The Islamic Peril: Media and Global Violence (Montreal: Black Rose Books, 2003).

43 Global Policy Forum, "War on Terrorism," https://www.globalpolicy.org/war-on-terrorism.html

44 Paul Delean, Montreal Gazette, "Terrorism used as an excuse to shut down dissent, conference hears," Oct. 10, 2010. http://therearenosunglasses.wordpress.com/2010/10/10/terrorism-used-as-an-excuse-to-shutdown-dissent-conference-hears/

45 Greg Philo and Mike Berry, More Bad News from Israel (London: Pluto, 2004).

46 Greg Philo. Skype interview. Oct. 24, 2013. 
47 Waisbord, op cit. and Jay Rosen in Barbie Zelizer and Stuart Allan (ed.), Journalism After September 11 (New York: Routledge, 2002).

48 Jay Rosen's "September 11 in the Mind of American Journalism" in Barbie Zelizer and Stuart Allan (ed.), Journalism After September 11 (New York: Rutledge, 2002).

49 Rick Hampson and Martha T. Moore, USA Today, "How 9/11 changed us: Person by person," Sept. 7, 2011.http:// usatoday30.usatoday.com/news/nation/story/2011-09-02/How-911-changed-us-Person-by-person/50246434/1

50 Liat Clark, Wired.co.uk,"US media helped anti-Muslim bodies gain influence, distort Islam," Nov. 30, 2012., http:// www.wired.co.uk/news/archive/2012-11/30/anti-muslim-influence-on-us-media

51 Ron Jacob, Counterpunch, “American Empire: the Feature Film,” July 7, 2012. http://www.counterpunch.org/2012/06/08/american-empire-the-feature-film/

52 Rosen, op cit.

53 Marwan Bishara, Arab Center for Research and Policy Studies, "U.S. Goals and Strategies Toward the Arab World," April 2003. http://english.dohainstitute.org/file/get/c1a362d4-d788-412c-8b51e91f6c14993f.pdf. See also, Abdel Mahdi Abdallah, Gloria Center, "Causes of Anti-Americanism in the Arab World: A Socio-Political Perspective," Dec. 6, 2003. http://www.gloria-center.org/2003/12/ abdallah-2003-12-06/

54 Robert W. McChesney, "September 11 and the Structural Limitations of U.S. Journalism" in Journalism After September 11, Barbie Zelizer and Stuart Allan (ed.), Journalism After September 11 (New York: Rutledge, 2002).

55 Bassam Haddad, Jadaliyya, "US on UN Veto: "Disgusting", "Shameful", "Deplorable", "a Travesty" . . . Really?" Feb. 5 2012. http://www.jadaliyya.com/pages/index/4237/us-on-un-veto disgusting-shamefuldeplorable-a-tra

56 Nazmi Al-Shalabi, Kifah Omari and Marwan Obeidat, International Journal of Humanities and Social Science Vol. 4 No. 4, "The Situation of American Studies in Jordan: Scenario and Diagnosis," The Hashemite University, Jordan, February 2014. http://www.ijhssnet.com/journals/Vol_4_No_4_Special_Issue February 2014/21.pdf

57 ibid.

58 Scheherezade Faramarzi, AP published on cbsnews.com, "Palestinians' Rage At U.S. Festers," published on CBS Website, April 23, 2004 - http://www.cbsnews.com/news/palestinians-rage-at-us-festers/

59 Scheherezade Faramarzi, AP archives, "Rabbis and Sheiks,” June 10, 1996.

${ }^{60}$ I do not have the raw copy.

61 Shaul Mishal, Avraham Sela, The Palestinian Hamas: Vision, Violence, and Coexistence (New York: Columbia University Press, 2006).

62 Waisbord, op cit. p. 204. 
63 Jason Burke, The Guardian, "Frankenstein the CIA created,” Jan. 17, 1999. http://www.theguardian.com/world/1999/jan/17/yemen.islam

64 Scheherezade Faramarzi, "How the Media Covers the Middle East," lecture at Brown University, Rhode Island, April 30, 2009.

65 PBS, Frontline, “Terrorist attacks on Americans, 1979-1988. http://www.pbs.org/wgbh/pages/frontline/ shows/target/etc/cron.html

66 ibid.

67 Waisbord, op cit. pp. 206-7.

68 Peter L. Bergen, The Osama Bin Laden I Know: An Oral History of Al Qaeda's Leader (New York: Free Press, 2006).

${ }^{69}$ US military forces killed three journalists in Baghdad on April 8, 2003. An Al-Jazeera correspondent was killed in a direct missile strike on Al-Jazeera's Baghdad offices. Shortly afterward, two cameramen, one with Reuters and another with the Telecino Spanish television were killed when a U.S. tank fired on Baghdad's Palestine Hotel which housed the international press. See $C N N$ Website, "U.S. attacks kill three journalists,” April 8, 2003 -http://www.cnn.com/2003/WORLD/meast/04/08/sprj.irq.hotel/

${ }^{70}$ Mujib Mashal, Al Jazeera, “Taliban 'offered bin Laden trial before 9/11,"” Sept. 11, 2011. http://www.aljazeera.com/news/asia/2011/09/20119115334167663.html

71 “The Covert Origins of ISIS," SCG News documentary, Aug. 28, 2014. http://scgnews.com/the-covertorigins-of-isis

72 Robert W. McChesney, in Barbie Zelizer and Stuart Allan (ed.), Journalism After September 11 (New York: Rutledge, 2002) P. 98.

${ }^{73}$ Nico Carpentier, The ideological model of war: Discursive mediations of the Self and the Enemy, (Amsterdam/New York: Rodopi, 2011) - http://www.inter-disciplinary.net/ptb/hhv/vcce/vcce1/carpentier\%20paper.pdf

74 ibid.

75 ibid.

76 ibid.

77 ibid.

78 Steven Barnet, Guardian, "Theatre of war," June 7, 1999. http://www.theguardian.com/media/1999/jun/ $\underline{07 / 8}$

79 Howard Tumber, "Information War and Journalistic Practice in the 21st Century," (2006). 


\section{Chapter 5: Summer of '06}

By 2006, the "war on terror" had all but become the dominant narrative in framing conflicts around the world. The "good guys" were as ever Westerners - and by association Israel - fighting the "bad guys" who "threatened" Western world order; fighting the unruly, undemocratic extremists bent on destroying Western-style democracies, a notion propagated by the U.S. and exploited by its autocratic allies to crack down on dissent. When on July 12, 2006, Hezbollah launched two simultaneous operations across Lebanon's border with Israel, it became about a terrorist group provocatively attacking Israelis going about their business on their side of the border. Most elements detrimental to the news were often missing: prominently context and history. While Hezbollah's goal in capturing the soldiers was to use them as "bargaining chips" in exchange for the remaining Lebanese "prisoners" held by Israel (similar prisoner exchanges had taken place a number of times in previous years), the act was portrayed as breaking with the norm in the volatile political and geographical landscape of Hezbollah-Israel confrontations. Hezbollah fighters were generally identified as "militant Shia Muslim" guerrillas, who - "infiltrated into Israel," "kidnapped"1 two soldiers, killed three and wounded two, and Israel merely retaliated for this provocation.

By the summer of 2006, Hezbollah had a well-trained, well-armed, highly motivated, and highly evolved war-fighting machine on Israel's northern border. It consisted of at least a 3,000-man strong light infantry and a commando brigade that was twice as large and overwhelmingly made up of veterans from the 18-year 
campaign against Israel. ${ }^{2}$ Hezbollah had calculated accurately and had designed an organization and operation plan based on well-grounded assumptions. As reserve IAF [Israeli Air Force] campaign-planning officer Ron Tira pointed out, "Hezbollah designed a war in which presumably Israel could only choose which soft underbelly to expose: the one whereby it avoids ground operation and exposes its home front vulnerability, or the one whereby it enters Lebanon and sustains the loss of soldiers in ongoing ground-based attrition with a guerrilla organization. Hezbollah's brilliant trap apparently left Israel with two undesirable options." ${ }^{3}$

Following the capture of the Israeli soldiers on July 12, 2006, Hezbollah fired rockets as a diversion at Israeli positions in two other Israeli sectors of the border. Israeli army commanders who only half an hour later learned about the initial attack, sent tanks and armored personnel carriers into Lebanon in pursuit of the soldiers. At 11 a.m. - two hours after the ambush of the soldiers - one of the tanks was destroyed by a land-mine that killed four crew members. It took the IDF many more hours - and one more soldier's life - to recover the damaged tank and the bodies of the crew members. ${ }^{4}$

Had a friendly army or militia carried out such a well-coordinated assault, mainstream Western media would likely have described it as a "daring" military operation as they commonly refer to Israel's attack on Iraq's nuclear reactor in $1981 .{ }^{5}$ In addition to its success in the initial operation, it would become the first time a small guerrilla that had been able to confront a mighty army such as Israel's. ${ }^{6}$ 
The AP and other news outlets generally reported Hezbollah's capture of Israel's soldiers as a “kidnapping. AP's Jerusalem bureau chief Steven Gutkin wrote: "Kidnappings changed everything: All that changed Wednesday, when Hezbollah guerrillas crossed into Israel, seizing Goldwasser and Regev and killing eight other soldiers in the ensuing fighting." A story by AP's Joseph Panossian on July 12 said: "Hezbollah militants crossed into Israel on Wednesday and captured two Israeli soldiers. Israel responded in southern Lebanon with warplanes, tanks and gunboats, and said eight of its soldiers had been killed in the violence." Israel's massive bombardment destroyed Lebanon's bridges and other infrastructure, as well as villages, mainstream media reported it as an effort to punish Hezbollah. ${ }^{7}$ Then Israeli Prime Minister Ehud Olmert declared that the Lebanese government, which Hezbollah was part of, would be responsible for the consequences - even though Lebanon's U.S.-backed prime minister, Fouad Saniora, had dissociated his government from Hezbollah's action. "If the soldiers are not returned, we will turn Lebanon's clock back 20 years,"8 threatened Olmert's Chief of Staff, Dan Halutz.

There were striking differences between AP's coverage of the 1982 and 2006 Israeli wars on Lebanon. While in 1982 the AP relied mostly on aggressive field reporting, in 2006, Israeli military communiques generally took precedence over journalists' reporting, leading some, including myself, to question the rationale of risking our lives when our reporting was not given a great deal of value. "We were being second-guessed on many cases," says Interviewee I (Appendix A, 36), a senior correspondent who covered the war. 
In this chapter, I demonstrate specifically how AP's coverage was unambiguously pro-Israel - in giving more space and prominence to the Israeli side: using few human interest stories that reflected the plight of Lebanese civilians compared to the barrage of stories about life in northern Israel under Hezbollah rockets; and the failure to prominently report Hezbollah's gains on the battlefield. Even when, for example, 16 children were killed in the southern Lebanese town of Qana as they took shelter, the AP took at face value Israel's position that blamed the deaths on Hezbollah for using them as "human shields," not checking if this was actually the case - which indeed proved not to be as documented a year later in a report by Human Rights Watch. ${ }^{9}$

Four events and issues will be examined to demonstrate how the AP covered the 2006 war: differences between the coverage by the Beirut and Jerusalem bureaus; controversy over casualty figures; the "human shield" allegation; and discrepancies in reporting military progress on the battlefield. In addition to technical and technological changes, geopolitical and "ideological" factors played a part. Nine current and former AP journalists interviewed - five on the record and the rest off the record - for this chapter shed light on the changes; they also give their opinions on the coverage. Also, Greg Philo, professor of Communications and Social Change at Glasgow University in UK, and co-author of More Bad News from Israel, analyzes in an interview for this thesis the general changes in media coverage of the Middle East.

Four Lebanese correspondents worked at AP's Beirut bureau in 2006. With the eruption of the war, three reporters from AP offices in Cairo and Islamabad, Pakistan 
came to help the Beirut operation, in addition to two of Cairo's senior editors who rotated in manning the desk in Beirut. I joined the coverage from my base in Rabat, Morocco about ten days after the war started. Other journalists joined later to replace the earlier visiting journalists.

By 2006, what was once the world desk that edited copy for points outside the United States had been replaced by a series of regional desks that took up that job. In the 1980s, copy written in Beirut was sent (via telex) to the New York International Desk for editing; Israel filed to New York separately. As a result, there were many competing stories on the wire. By the late 1990s, regional desks were created, including one in Cairo. Staffers filed by computer and could communicate electronically across borders with ease. As a result, there seemed to be fewer competing datelines in the 2006 coverage: Beirut handled a cycle if it had the stronger material and Jerusalem did a sidebar (side story that accompanies the mainbar or main news story); if the Israel story was stronger, it did the mainbar and Beirut did a sidebar. This is not to say that New York was not involved: the top editors met in the conference room at about 10 a.m. to pick the stories for the A-Wire (American) budget. The editors on the international desk would then call Cairo to let editors there know what New York wanted. In 2006, reporters and editors in Cairo, Beirut or Jerusalem could call up several stories from different places on different screens and simply shift the material into the copy. This made the stories more a roundup from everywhere than an account of what was happening in south Lebanon or northern Israel. In 1982, even when staffers were aware of an event outside Lebanon that 
should have been included in the story, they had to laboriously re-type it into the copy. Since the day-to-day stories did not include as much analysis as AP stories in general do today, bureau chief Nicolas B. Tatro was given an internal AP prize for his coverage of the 1982 invasion based on his news analyses. While it added perspective, it also meant there was less room for the details on the ground. The mechanics behind the coverage also played a part in this shift of emphasis.

A drawback of the new system, however, was that some of the stories, which carried datelines from south Lebanon, "had very little sense of place and not much feel for the suffering of civilians," says GG Labelle (Appendix A, 13). The stories that were filed on the A-wire for American clients "tended to try to pack in everything from Lebanon, Israel, Washington, the United Nations and anywhere else somehow involved - very much to the detriment of actual events witnessed by a reporter at the scene of fighting."

Alfred De Montesquiou (Appendix A, 16), an editor who sent the first news alerts on the war from Cairo, says in an interview, that Cairo - AP's Mideast control bureau - was neutral in its coverage of the 2006 war, and describes some of the tensions between the Cairo and Jerusalem bureaus:

We were a little bit suspicious of Jerusalem [bureau] being slightly off balance. ... I remember there was talk of war between Jerusalem and Cairo about who would have the mainbar. At the beginning it was mostly us, then they started taking it and at one point it was a bit ridiculous and some agreement was reached between Cairo, Jerusalem and New York. Basically the mainbar would shift every cycle. We would file every half cycle, so every 12 hours the mainbar depended on where the biggest news was. Everybody would do the urgent sidebars, but there would be one wrapup because at one point there were two 
competing stories, like two competing narratives being filed simultaneously out of Jerusalem and Cairo!

The dominant narrative - and theme - of the AP coverage shifted as the war went on for 34 days. At first it was Israel fighting for the return of two of its soldiers, as well as efforts by Israel to destroy Hezbollah. The kidnapping was mentioned in almost every story during the war. ${ }^{10}$ Also, the theme was that Hezbollah overplayed its hand in capturing the two soldiers. Later, it became that Israel overplayed its hand in the severity of its response, which still did not allow it to achieve its goals. ${ }^{11}$ There were a few analytic pieces that generally succeeded in putting the war in context. Among them: one that reviewed Israel's destruction of Lebanon's civilian infrastructure, ${ }^{12}$ and another on Israel expanding the war into a broad campaign to alter the Middle East. ${ }^{13}$ One effort at historical perspective was "Mideast-Echoes of ' 82 '"14 - one of the few stories that compared the 2006 war directly with the 1982 conflict. One of the first stories I covered that ran as an "urgent" was an interview with a senior Hezbollah official, Mahmoud Komati, who admitted that his group was surprised by Israel's strong reaction to the capture of two of its soldiers. ${ }^{15}$ Some of my sources who had close contact with Hezbollah promised to help me interview Hezbollah children for a story on how youngsters perceived the war. AP New York was very interested in anything that gave a slice of Hezbollah life, so it encouraged me to go ahead with the story idea. However, a deputy foreign editor remarkably cautioned in a private AP message (Appendix C, 5) against making the story come across as pro-Hezbollah. "On the children, I really think you could give it an edge by 
making it the children of Hezbollah specifically. You'd have to be careful not to make it a sympathy piece for the organization, of course," he wrote, making me wonder at the time if he would have asked the same were the story about children of Israeli ordered American military personnel.

When I visited a southern Beirut residential suburb, a Hezbollah stronghold, and wrote about a family returning after a week to retrieve personal belongings from their damaged home, the AP only used it on the world wire and not on the more important American wire. Later, a senior editor who was in Beirut to direct the war coverage, informed staffers, including me, that "New York has no appetite for features from Lebanon" - that is, human interest stories. This was at a time when AP's Israel bureau was frequently filing features on the struggle of Israeli civilians living under Hezbollah's rocket fire in the north of their country. Such stories included the agonies of civilians in a public bomb shelter in the northern town of Nahariya where "plumbing has become a matter of life and death,"16 or one on civilians in Kiryat Shmona, also a northern border town, "going stir crazy" in bomb shelters. ${ }^{17}$

Yet when on August 1, 2006, Israel raided a Hezbollah-run hospital in the ancient city of Baalbek and bombed the surrounding areas, ${ }^{18}$ killing seven civilians, the same AP editor was not interested in a human piece from there. I had been assigned by New York to write a comprehensive story on Hezbollah. Several hours after the August 1 attack, the editor asked me to travel to Baalbek, a dangerous route. I agreed that it was a good idea to report on the previous night's bombing. However, he said he only wanted me to go there for the more dramatic dateline of Baalbek for 
the big Hezbollah story. "No need for a story, go there and have lunch somewhere. We just want you there for the dateline," he told me (Appendix C, 6). When I returned to Beirut later that day with details of the bombing, ${ }^{19}$ the editor did not file it on the American wire. When I later complained to senior New York editors, I was told the editor had said the story was "shallow" (Appendix C, 7). Also, New York told denied that they had told the editor that it had no "appetite" for human sidebars from

\section{Lebanon.}

AP's lack of interest in Lebanese civilian suffering is illustrated in two of its most widely used features from Lebanon during the 2006 war: the rescue of 113 dogs, and a cliché story about the Lebanese persisting in their enjoyment of nightlife despite the war. ${ }^{20}$ Stories of human suffering in flattened neighborhoods did not easily make it to print in America. Reporting from the front was hindered by Israel declaring in the early days of the conflict that "everything" 21 was a legitimate IDF target in Lebanon, ${ }^{22}$ "not just southern Lebanon, not just the line of Hezbollah posts" - making it very dangerous for journalists to operate. Israeli Justice Minister Haim Raimon went further and notoriously declared:

All those now in south Lebanon are terrorists who are related in some way to Hezbollah. So if you take to the roads to flee, you are a terrorist - who else would travel the southern roads now? And, if you stay at home because the danger is so great, you are also a terrorist. For the innocent civilian, there is literally no way out. ${ }^{23}$ 
In reporting the Israeli ultimatum on the first day of the war, the AP lead presented the warning as conditional on the Lebanese government's failure "to rein in Hezbollah guerrillas." ${ }^{24}$ It added: "Since Israel's withdrawal from Lebanon in 2000, Hezbollah has carried out cross-border attacks, including Wednesday's ambush in which guerrillas captured two soldiers and killed eight." ${ }^{25}$ The story seemingly "justified" the Israeli threat to attack Lebanese civilians.

On August 7, Israeli warplanes dropped a leaflet banning the movement of any vehicle south of the Litani River, turning the entire region into a free-fire zone trapping about 100,000 civilians in south Lebanon. “Any vehicle of any kind traveling south of the Litani River will be bombarded, on suspicion of transporting rockets, military equipment and terrorists," the leaflets said. By August 13, the AP reported, "Aid convoys were stuck in ports or at warehouses because Israel refused to guarantee their safety on the roads. Thousands of people trapped in southern villages were believed to have run out of food and medicine and were drinking unsafe water."26

"We thought twice about sending AP reporters to these areas. I don't think it was policy, but I remember thinking that's really dangerous," says Interviewee J (Appendix A, 37). Despite such measure and its "disregard for civilian lives," ${ }^{27}$ Israel blamed Hezbollah for the huge civilian toll in Lebanon, claiming they were using them as "human shields" or hiding their rockets in civilian homes. However, Human Rights Watch, while accusing Hezbollah of deliberately and indiscriminately attacking Israeli civilian targets, found no evidence to support the Israeli allegations. 
"We can't exclude the possibility that it happens - but time and again villagers tell us that Hezbollah is fighting from the hills. Meanwhile, the homes hit by Israel have only civilians in them." 28

The term "human shield" has been used as a crux of Hasbara to absolve Israel of responsibility when it attacks hospitals, refugee centers, or homes, killing civilians. It was no surprise, therefore, that on July 15 missiles were fired on a fleeing three-car convoy draped with white flags after being instructed by the Israelis through loudspeakers to evacuate the village Marwaheen immediately or face shelling. Twenty-three people, mostly children, were killed. There was no TV footage from the aftermath of the gunship and helicopter attack on the destroyed pick-up van nor of the blackened soil where the missiles crashed. Israel never apologized for the massacre of Marwaheen residents. AP did not report on the massacre at the time. On the day the ceasefire was announced - August 14 - an AP story datelined Marwaheen did not mention the massacre. ${ }^{29}$ It did, however, remarkably refer to the arrival of Western journalists as "intruders" who had driven into Marwaheen while the Israelis were still present in the village. It was not until 45 days after the attack that a story from Marwaheen focused on the massacre. ${ }^{30}$ Another AP story, ${ }^{31}$ dated September 29, 2006 from Marwaheen, made a passing reference to the massacre in the 21st paragraph, without identifying the perpetrators: "Marwaheen, a Sunni village that survives on tobacco and olive crops, made headlines when vehicles carrying residents fleeing this summer's war came under missile fire that killed 12." The headlines, however, did not belong to the AP. 
The daily AP copy on the war's progress was mostly based on Israeli claims, such as destroying rocket launchers and medium-range missiles. Throughout the war, phrases such as "Israeli strikes on Hezbollah targets" 32 were repeated consistently. However, on the ground, it was largely Lebanon that was being destroyed and its people killed, not Hezbollah. Rarely did stories report Hezbollah's attacks on Israeli tanks as an "effort at resisting one of the world's most powerful military machines." 33 Instead, stories often referred to Hezbollah rockets striking northern Israel, while Israelis retaliated by bombing "Hezbollah strongholds" - even though these stronghold were also neighborhoods and "support among their residents for Hezbollah could not have been any less than Israeli citizens' support for their own military." 34 If Hezbollah areas cannot be considered neighborhoods, then why not refer to Israeli neighborhoods as 'Israeli military strongholds?”” asked blogger Habib Battah of the Journal of Middle East Broadcasters. ${ }^{35}$ The lack of balance, he said, "conveys humanity on the one side and vague militarism on the other."

On July 17, five days into the war, Israel dispatched limited ground forces that launched mostly of large-scale raids into Lebanese areas adjoining the border. In conjunction with air raids and ground battles, the Israeli navy imposed a blockade on the Lebanese coast. ${ }^{36}$ There was little indication in the AP copy that Israel was in fact facing great resistance from Hezbollah and its forces were being pushed back rather than make advances: An AP story ${ }^{37}$ on that day, with two bylines from Lebanon, yet datelined Jerusalem, said: "Israeli ground forces entered southern Lebanon to attack Hezbollah bases there, an Israeli government spokesman said Monday. The 
announcement came after Israeli fighter bombers pummeled Lebanese infrastructure Monday, setting Beirut's port ablaze and hitting a Hezbollah stronghold in attacks that killed at least 17 people." If a Hezbollah stronghold was hit, it would be assumed that the dead would be guerrillas, but the AP did not clarify who was killed. It continued the Israeli narrative: "Israel said its planes and artillery struck 60 targets in Lebanon overnight as its military sought punishment for the barrage of 20 rockets on Haifa." Hezbollah, the story added without any qualification, "is engaged in escalating warfare with Israel" - seemingly blaming Hezbollah for the bloodshed. Again it quoted the Israeli army as saying it had targeted a radar station that was used by Hezbollah to hit an Israeli warship - even though Hezbollah was not known to operate in northern Lebanon. The AP story explained without evidence that an Israeli missile that hit a private house in southern Lebanon, killing two people, "missed its target - a Hezbollah site," reinforcing the narrative that Israel avoids civilian deaths. The sources in the story - by two correspondents in Lebanon, one of whom was reporting from southern Lebanon - for the military activities were exclusively the Israeli army with one Lebanese security official giving a casualty toll. The dateline, for some reason, was Jerusalem. It is true that Hezbollah did not routinely provide military statements during the war, but one story ${ }^{38}$ highlights how AP gave more value to Israeli statements even when they contradict the reporting of its own journalists. When heavy battles in the Lebanese town of Bint Jbeil killed a number of invading Israeli soldiers, the AP quoted Prime Minister Fouad Saniora with the death toll, which turned out to be much higher than the eight that was established later. 
Interestingly, however, before it was clear that Saniora's figure was inaccurate, the AP story added the line: the number could not be independently verified. Regrettably that story which was later updated with the lower toll is no longer accessible on the internet or in the AP archives. I know this for a fact as I mentioned it to the editor on the desk (Appendix C, 8) who shrugged it off. It is worth noting that in my experience such clauses rarely, if ever, appear regarding statements from Israeli officials.

While Arab broadcasts, including BBC's Arabic Service, were reporting Israel's failure to make any substantial advances on the ground, AP's roundup ${ }^{39}$ of the fighting filed from Jerusalem on July 28 without skepticism quoted the Israeli government as explaining why Israel was not advancing on the ground: "Israel's government decided Thursday not to expand its battle with Hezbollah in southern Lebanon for now, but authorized the army to call up 30,000 reserve soldiers in case the fighting intensifies." It went on to give Israel's successes - citing Israeli government officials - in striking Hezbollah targets: 130, including a base where long-range rockets were stored, 57 Hezbollah structures, six missile launching sites, and six communication facilities. Jets also fired missiles at a building near the southern market town of Nabatiyeh.

An AP editor showed no enthusiasm when I mentioned (Appendix C, 9) AP's failure to address Israel's inability to make any substantial troop advances on Lebanese soil. I suggested I would talk to a few military experts to determine whether Israel indeed was not only unable to advance in the south, but was being continually repelled by Hezbollah. When the story ${ }^{40}$ was ready to go, the editor recommended 
(Appendix C, 5) that I water it down and refrain from suggesting that Israel was losing the war. It only moved on AP's lesser significant PMs cycle.

As during the 1982 invasion, controversy over civilian casualties boiled over during and long after the 2006 war. Some 1,183 Lebanese, about one-third of them children, and 39 Israeli civilians were killed. ${ }^{41}$ Some 4,054 Lebanese were injured and 970,000 displaced. In addition, 117 Israeli soldiers were killed. There is no credible figure for the number of Hezbollah fighters killed, though the best estimate is somewhere between 150 and 170. The IDF also killed 43 Lebanese security force personnel. ${ }^{42}$ Hezbollah launched thousands of rockets "on northern Israel," and the Israeli air force carried out more than 7,000 air attacks on about 7,000 "targets" in Lebanon between 12 July and August 14; its navy conducted an additional 2,500 bombardments. The Lebanese government estimated that 31 "vital points" (such as airports, ports, water and sewage treatment plants, electrical facilities) were completely or partially destroyed, as were around 80 bridges and 94 roads. In Israel, the level of physical destruction was far lower. The pro-Israeli blogger Michael Totten wrote on August 18: "I drove to Hezbollah's most targeted city of Kiryat Shmona to do a little post-war analysis... I expected to see at least one destroyed house... I drove all over and couldn't find one. Katyusha rockets are pipsqueakers."43 Amnesty International reported in August 2006: "The evidence strongly suggests that the extensive destruction of public works, power systems, civilian homes and industry was deliberate and an integral part of the military strategy, rather than 'collateral damage." $" 44$ 
Recalls Interviewee E (Appendix A, 32), who was tasked with gathering the casualty toll for the AP:

The problem was that the Lebanese did not record their casualties in the same neat and efficient way that the Israelis did. It was a struggle every day to find someone to give us the death toll at the end of the day. Always there were conflicting reports from security officials, the Red Cross and the Health Ministry if we could get to them. So it was a bit messy. There were no proper documentation. ... Hezbollah used to give [casualty figures] on specific incidents, but not all the time. They didn't keep a tally.

The civilian casualty controversy reached a peak on July 30, 2006 when Israel bombed a building in Qana, a village about 10 kilometers southeast of Tyre that is not a Hezbollah stronghold - where civilians had taken refuge from the war, killing 28, more than half of them children. Israel alleged Hezbollah had used the civilians in the building as a "human shield." Human Rights Watch in a report a year later, found: "Israeli officials have made the serious allegation that Hezbollah routinely used 'human shields' to immunize its forces from attack and thus bears responsibility for the high civilian toll in Lebanon. Apart from its position near UN personnel, Human Rights Watch found only a handful of instances of possible shielding behind civilians, but nothing to suggest there was widespread commission of this humanitarian law violation or any Hezbollah policy encouraging such practices. These relatively few cases do not begin to account for the Lebanese civilians who died under Israeli attacks. ${ }^{\circ 5}$ A near scandal erupted when Lebanese civil defense rescuer Salam Dhaher was photographed with a dead baby in Qana. 
After hours of digging, Dhaher emerged with the youngest victim. In a parched voice, he shouted something in Arabic and held the child up for the photographer. To many in the West, such photographs are surprising; but they are not unusual in the Middle East, where grief and drama are often intertwined, and that can include displaying of bodies. Dhaher cited 51 fatalities including 22 children, though later reports revised this to a lower figure of 28 , including 16 children. The photographs led to a number of websites accusing him of being a member of Hezbollah and of using bodies for propaganda purposes. ${ }^{46}$

A pro-Israel Website posted a video asserting that Dhaher had arranged for the child's body to be taken off an ambulance to be displayed for photographers. British author Richard North charged that Dhaher had taken control of the scene "to orchestrate false photo opportunities with the dead bodies." North later admitted to the Washington Post that he had no evidence that Dhaher was connected to Hezbollah, adding, "all I have to go on is gut instinct." ${ }^{47}$ The AP twice interviewed Dhaher who said he was not affiliated with any party. Commenting on his display of some of the bodies in Qana, he said: "I did hold the baby up, but I was saying "look at who the Israelis are killing. They are children. These are not fighters. They have no guns. They are children, civilians they are killing." 48

The media, which had no qualms about hailing rescuers digging for bodies as heroes on $9 / 11$, or echoing the anger felt for the suffering of the victims, would not allow the same honor to Lebanese respondents, or the same compassion for innocent civilians. In an analysis piece from Cairo, the AP, without evidence, took Israel's position for granted, accusing Hezbollah of using children as "human shields." A proposed lead that was sent to the New York desk read (Appendix C, 10). 
It's hard to beat a group of militant extremists who can use civilians as shields, melt into the local landscape at will and are pros at propaganda. The U.S. learned that after Sept. 11 and in Iraq. Now Israel faces the same conundrum - finding airstrikes deadly for civilians and ground incursions risky as it tries to wipe out Hezbollah."49

The final copy that appeared on the wires was slightly changed to read:

It's hard to defeat a group of extremists who can mingle among civilian supporters and are pros at propaganda. Israel's military faces the same conundrum the United States has encountered elsewhere finding that airstrikes are costly in civilian deaths and public support, while ground attacks are risky for soldiers. ${ }^{50}$

The human shield charge came in the third paragraph, albeit less strongly and attributed to Israel: "Israel apologized for the deaths and blamed Hezbollah, accusing it of using civilians as human shields." Israel's human shield charge against its enemies is deflated in a report by the Arab Association for Human Rights, an Israeli group that says the Israeli army placed military hardware, including artillery positions, inside Arab towns and villages during the 2006 war. $^{51}$ The overwhelming number of the Israeli civilian casualties was its Arab citizens in the north.

The AP analysis also prominently introduced the "war on terror" narrative:

The United States knows this scenario well from Iraq and elsewhere: Pictures of dead children and women killed in airstrikes can hurt support even among friends. ... Hezbollah's strength comes from its ability to hide fighters and weapons - both among the populace and in bunkers and tunnels - who can pop up once the Israelis pass by and fire more missiles toward Israel. That ability springs from its wide support among people in southern Lebanon.

Defense Secretary Donald H. Rumsfeld famously called it "asymmetric warfare" and identified it as the challenge America faced from terror groups after the Sept. 11 attacks, and from al-Qaida linked groups in Iraq. Israel faces just such a struggle against both Hezbollah 
in Lebanon and the militant group Hamas in Gaza, says Jon Alterman, a Mideast expert at the Center for Strategic and International Studies in Washington. ${ }^{52}$

The selection of certain analysts and "experts," as in the above passage echoes Edward Said's argument: it reveals the story's bias. A “core of experts" - or "careerist publicists" on the Islamic world, Said wrote, "has grown to prominence, and during a crisis they are brought out to pontificate on formulaic ideas about Islam on news programs or talks show" 53 and "have found a new field for their skills in demonology."

In several AP stories, death tolls were mentioned toward the bottom of the stories. When earlier in the war they were reported high in the stories, they often said "more than 900 people died," with no indication that the bulk was Lebanese.

As anyone who has worked for a news agency knows, essential details such as death tolls can get shoved down lower in the story as events develop and the new stuff gets put in at the top. Then leads have to be done to bring the relevant facts back into perspective. As a practical matter, in 1982 we would never have put an overall death toll in the last graph of a story because we'd have had to write through the entire story to update. In those days so-called write-thru leads were not common as they are now. Usually a whole new story was only done at the change of cycle, or twice in a day." 54

Pressures from outside to modify - i.e. water down casualty figures - were relentless. Three years after the war, on Sept. 5, 2009, the head of the Cairo-based Middle East operations, sent a message (Appendix C 11$)$ to Beirut staffers that New York had received a "complaint" about a story from Lebanon that said the 2006 war had killed about 1,200 people in Lebanon, most of them civilians. The complainant said "we ought to have phrased it as 'of the approximately 1,200 Lebanese deaths, 
Lebanon says most were civilians but Israel said 500 were Hezbollah fighters and released names of those it said were Hezbollah."' It referred to a December 2006 AP story $^{55}$ that gave the civilian death toll of 1,000 in addition to AP and Lebanese government figure of 250 Hezbollah dead and the Israeli figure of 600 dead Hezbollah. In an apparent attempt to appease the complainant, the AP chief was prepared to cast doubt on a toll gathered by AP's own staffers. In the email, she asked if there should be a correction or clarification. On Sept. 17, 2009, in an emailed memo (Appendix $\mathrm{C}, 12$ ) to senior editors on the international desk in New York, she wrote: (Note the use of the word 'failed,' and that AP adhered to complainant's alternative phrase.)

In the end, I do think we need to run a clarification on this story from Lebanon about casualties in the 2006 war, which you had asked about a while ago. ... The clarification should say essentially: 'The Associated Press in a story dated xxx failed to note that facts about casualties from the 2006 Hezbollah-Israel war remain in dispute. The month-long war killed about 1,200 people in Lebanon. Lebanon says most of those killed were civilians, but Israel says 600 of the number killed were Hezbollah militants.' I also have cautioned the Beirut bureau that we need to use wording like this in future stories, and not just say it killed mostly civilians - since that remains in dispute. The last story AP did showed at least 250 were Hezbollah but that story was from late $2006 .{ }^{56}$ Israel has released the names of 600 people it says were Hezbollah. Lebanon has never explored the issue further beyond saying Hezbollah were about 250 or 300 killed. ${ }^{57}$

It was not clear how Israel was able to have, not only an accurate number of

Hezbollah casualties, but also their names. What was more clear, however, was that

Israel's PR had succeeded in cowing AP into calling into question its own reporting. 
On August 31, 2007, in reporting the death of an Israeli man from wounds he suffered during the 2006 war, a story from Jerusalem said that the new death raised the Israeli fatality of the conflict to 159 , without mentioning the number of Lebanese killed. When I mentioned this to Cairo (Appendix C, 13), an editor there messaged Jerusalem:

We are careful to put in our stories from Lebanon, Cairo how many died on EACH side, I think that's only fair and accurate (not to mention how important something like that will become when we file online, under a Mideast page ... I mean, any story JER(usalem) files goes to the world, ...). Can you please stress this point to Jerusalem? I'll mention it to Gutkin ${ }^{58}$ also.

The story was updated with the Lebanon casualties.

Arab Media Watch charged in December 2006 that after a two-month investigation, it found that the AP persistently failed and refused "to explain how it came up with its curiously low Lebanese death toll" from that summer's war, ${ }^{59}$ saying it was about 30 percent less than most other sources - including the Lebanese authorities, the UN, human rights groups such as Amnesty International and the International Medical Centre, and much of the media and other newswire services such as Reuters and Agence France Presse - which oscillate around 1,200. ${ }^{60}$ It added:

Dated 31 October, it [AP] mentioned "more than 1,000 people dead on both sides, according to the UN and Israeli and Lebanese officials," but then stated that "of the total deaths, 159 were in Israel, including 39 soldiers.' Besides the fact that AP's figure for Israel's military casualties was wrong (39 civilians died, the rest were soldiers, according to the Israeli government), the maths still added up to around 850 Lebanese dead. The UN and Lebanese officials told AMW that at no point after the war did they release a Lebanese death toll as low as 850. In fact, they said the Lebanese toll had surpassed 1,000 well before the war ended, so the article was wrong to cite them as 
sources for the figures AP published. The HRC and Unicef were also cited as sources, but only to say that most of the Lebanese dead were civilians, and about a third were children. ${ }^{61}$

Arab Media Watch accused the AP of being uncooperative when contacted for clarification of the discrepancies and at one point was told the figures were given to them by HRC and the Lebanese Health Ministry and that they were "on-the-record figures that we're getting that we asked for precisely." However, it said, Jack Stokes, AP corporate communications in New York, "refused to tell AMW who AP's points of contact were at the HRC and the ministry, and told us to ask them who AP spoke to."

As strange and long-winded as that sounds, this is what we did. The HRC denied putting out a figure of 850 , giving it to AP or being contacted by them. The ministry also denied Stokes's claim. After refusing to tell us who the precise sources were, he then said he did not know who they were. Nonetheless, Stokes said he is 'still standing by' AP's figures and that 'we're comfortable with what we have out there and how we proceeded to get those numbers.' He added: 'Don't mistake my inability to tell you how precisely we arrived at this estimate with the journalism that went into producing it. ... We don't usually tell people what the details are and how we come up with certain things. ... I can't precisely explain how we got those precise numbers. ... You think it's that simple? ... We normally say, but you know...'62

Former AP's Alfred De Montesquiou (Appendix A, 16) compares the difficulties in reporting the Lebanese civilian casualties in 2006 with those of Palestinians during Israel's 2008-9 war on Gaza. Cairo bureau, he says, was anxious that the story he filed would go through them "because they were angry at how Jerusalem (bureau) was watering down and totally one-siding the copy. When I entered Gaza ... it was agreed between me and Cairo - I don't know if they decided it 
in New York or not -that I would not send my copy for editing to Jerusalem, but to Cairo, so that there would be a proper side of the story. Obviously it's an American (news) agency, we know that, but I didn't have the impression that it was that much watered down at the AP [in Cairo]."

Even though the Israeli military confirmed that the destruction of Lebanon's infrastructure was one of its goals, AP staffers in Beirut were instructed not to say so in stories. The reason, the staff were told, was because when the chief of the AP Mideast operations made a brief visit to Beirut in late 2006, she had not seen any destruction on her 15-minute drive from the airport to the AP office.

Israel may have succeeded in setting the tone for mainstream media coverage by its repeated outrage over the Hezbollah rockets and capture of its soldiers. But the war, which was at first popular inside Israel, eventually proved to be a disaster after it failed to achieve its declared goals - winning the soldiers' release and crushing Hezbollah. A report released in Jerusalem in January 2008 termed the war "a big and serious failure." ${ }^{93}$ Israeli Defense Minister Amir Peretz resigned after the report's release and later lost his post as head of the Labor Party. Halutz, the chief of Israel's military, also resigned. Although Prime Minister Ehud Olmert stayed in office, his public approval ratings remained very low. ${ }^{64}$ But the war boosted Hezbollah and its leader Hassan Nasrallah's popularity not only among the Lebanese Shias, but millions of the world's Arabs who were angered and ashamed by their government's perceived acquiescence to U.S. - and even Israeli - policies ${ }^{65}$ Even if it did not win an outright victory over Israel, Hezbollah was seen to have put up a good fight. "Nasrallah is 
doing what Arab governments are unwilling or incapable of doing - fighting Israel. He is embarrassing them," the AP quoted Vali Nasr, an expert on Shias, as saying. Another AP story, ${ }^{66}$ almost like a page from a U.S. State Department website, alarmingly warned of "the biggest risk" if the war "tipped the balance toward extremists and away from moderates across the Middle East, including in Lebanon, where the government has been dramatically weakened by the fighting. Damage to the fledgling democratically elected government would be a loss for the United States as it struggles to realize its secular vision for the region.”

The story warned that Egypt and Saudi Arabia that it described as moderate states, directed "harsh words on Israel." It added: "Yet as the fighting goes on, the mood is shifting perceptibly, at least among average Arabs, from anger at Hezbollah to more-familiar feelings of hostility toward Israel." It urged "Western-leaning and pro-democracy supporters in Lebanon" to "rejuvenate the street strength" and push for democracy ... the moderate side," in order to survive. "All of that is bad for both the United States and moderate Arab allies, such as Saudi Arabia and Egypt, who America depends on to carry its agenda in the Mideast. Those countries, on the defensive as Hezbollah fights Israel, lose their ability to push for peace talks or mediate for moderation behind the scenes with other militant groups like Hamas."

"To describe it overall, my feeling was that there was so much happening [that] we were struggling to verify it all, and I felt the report was incomplete and we weren't giving justice to the scale of the bloodshed," says Interviewee J (Appendix A, $37)$. 
In a way I just felt jealous that on the Israeli side they had the tools do it better, tools including information from the Israeli military. Some of the reporters in our Jerusalem bureau were Israeli [army] reservists and had very good sources ...I felt they could do a more accurate representation than we would, so I felt the information was lopsided. I felt we were running and giving it our all, like hamsters on wheels; we were working so hard and such long hours and I felt we didn't do justice. ${ }^{67}$

"In 1982, the AP used to pride itself of long stories, features and being distinctive," says Interviewee I (Appendix A, 36). "In 2006, we got to a point where we only had to state near facts quickly, very short stories; we were told newspapers do not want very long stories, they don't want all the details. We were being second guessed on sources, second guessed on casualties."

The 2006 war witnessed a successful use of the social media, highlighting the importance of the "new media" in contemporary war. With technological advances such as the use of satellite, the AP had by 2006 equipped staffers with AP Web video and journalists did standup reading of the news using APTN video. "A broadcast writer put it together from the mainbar and I read it on camera," says Lauren Frayer (Appendix A, 6), a Cairo-based reporter on assignment in Beirut, in an interview.

While the conflicts of 1982 and 2006 are linked in several important respects, they are important studies in contrasts. Their common denominator is the Israeli military - a conventional armed force - that fought in a country with non-state adversaries, the PLO and Hezbollah. Comparisons between the 1982 and 2006 wars can also be made in the military, regional and political landscapes. The earlier war was a full-fledged invasion with indiscriminate bombing of Lebanon and the eventual 
siege of Beirut. The Israelis fought not only with the PLO, but also with Syria's occupation troops in Lebanon, while having allies among Lebanon's Christians. AP did many good reports in 1982 and staffers received a great deal of support from headquarters. Just as the AP did its best to cover Arafat and his lieutenants in northern Lebanon in the 1980s, reporters in 2006 covered Hezbollah leader Hassan Nasrallah and his lieutenants (Nasrallah did not make any public appearances until after the 34 days of fight ended, speaking either on TV or in statements before that. Arafat, on the other hand, was front-and-center in the days before the Palestinians were forced to leave Beirut.)

The starkest contrast, however, lay in the extent and ferocity of the Israeli attacks in 1982. Eleven days into the 1982 war, wrote Charles J. Hanley, an estimated 10,000 people had been killed in Israel's air and ground assaults, compared with official tolls of at least 380 Lebanese and 36 Israelis in the same period in the second war. ${ }^{68}$ Unlikely the PLO, which was weak and had no military strategy, Hezbollah in 2006 fought vigorously, proving a tough adversary for Israel. It fired thousands of rockets unprecedentedly as far south as Haifa. Every time it fired its rockets, Israel won more sympathy with its American and European allies; yet sympathy for Israel did not wane when it hit cities and civilians in Lebanon, reflected in mainstream American media.

Apparently because of the disproportionate number of civilians killed in Lebanon compared to those in Israel did not win the Lebanese sympathy from the American public, the media were less outraged by the numbers of deaths or 
destruction in Lebanon. In 1982, there was considerably more world sympathy for the Palestinians than there was for Hezbollah in 2006; and far greater world sympathy for civilians in Lebanon which contributed to a stream of human stories. UN SecretaryGeneral Kofi Annan found blame on both sides in 2006, accusing Israel of "excessive use of force" and Hezbollah of holding "an entire nation hostage" with its anti-Israel campaign. ${ }^{69}$ While in 1982 the war was predominantly one-sided and Israel was not being hit, in 2006, the fight was on both sides. Also according to Interviewee I's (Appendix A, 36) assessment, compared to the earlier war, in 2006, the Israelis "were not as much off target and hit many of Hezbollah's positions."

They hit bridges which were not Hezbollah targets, but they did hit a lot of places that they had in their data as potential Hezbollah positions. Because they hit more Hezbollah targets than PLO positions in 1982, they were able to deflect some of the criticism from the West. They could say, 'we are hitting legitimate targets and if civilians were hit, they would say they made a mistake. ${ }^{70}$

It would be unfair to suggest that the Western media did a poor job covering the 2006 war when many field reporters risked their lives to tell the story and write about the suffering of the civilians. But Israel's public relations apparatus - Hasbara had become very sophisticated by 2006. Israeli spokesmen had become experts in conducting "extremely clear and well-organized soundbites and clearly designed sets of causal relationships, ${ }^{71}$ that included: “"we're being attacked, we don't want to have war, we want peace but have no choice but try to stop the constant attacks from rockets,"” says Greg Philo (Appendix A, 21) in an interview for this thesis. "These are being said again and again by different spokespeople." Journalists under pressure to 
omit explanations of the Arab side, he says, try to compensate by writing features on their suffering, "which for them would be a strong ground to be on."

If they are showing pictures of dead children or widows or people's funerals or whatever, especially if they are defined as innocent victims, then, that gives the journalists a kind of stronger [ground to stand on]... because they can't be criticized for showing pictures of innocent babies that are being killed. ${ }^{72}$

However, the impact of these human interest features on the audiences is weakened by Israel's sophisticated public relations campaign. "People see the images as awful and terrible, but the images make no difference because they don't have any conceptual framework to fit them in," says Philo. Referring to his research on how television news shapes 80 percent of the British audiences' opinions about the IsraelPalestine conflict, ${ }^{73}$ Philo says in the interview: "The quality of what they see and hear is so confused and partial that it is impossible to have a sensible public debate about the reasons for the conflict or how it might be resolved."74 Philo's study can also apply to Israel's 2006 conflict with Lebanon:

The only framework - not an alternative - they have is the Israeli one .... we found again and again, people were saying, 'terrible, yes, it's awful and shocking pictures, it's terrible what's happening to the Palestinians, but if only they would stop firing the rockets. And then they would just give you all the explanations that were being put out by the Israelis, because the Israelis completely control the explanatory frameworks through which the conflict was understood. And what followed from that was - which is very important - it didn't matter what the people saw. You could show them the most gross, appalling imagery and one woman, you could see in the book, is quoted as saying the pictures made her cry when she saw dead Palestinian children, she cried, but it didn't make her sympathize with the Palestinians because if only the Palestinians would go for peace; if only they would stop fighting, if only they would stop attacking the Israelis. So it didn't matter what they saw. 
And I think that's also a product of the growing - you might call - the grotesqueness of imagery in the media, not just in news programs, but generally in fiction and in programs like CSI. Everyone knows now what it looks like when a bullet hits a head, they've seen it so many times in CSI and people expect war to be bloody and brutal and appalling and awful and in a way the images don't actually shock them anymore. They sadden them and upset them, but they want to know how is it possible to stop it and who is responsible? Why is this happening? Who is doing it? ${ }^{75}$

The Hasbara effort in 2006 also consisted of bloggers launching aggressive campaigns to discredit any story or photo that portrayed Israel in a negative light. Pro-Israel bloggers were up in arms when an AP reporter opinionated in his personal blog ${ }^{76}$ in the early days of the 2006 war, prompting the AP - which rightly instructs its employees to "refrain from declaring their views on contentious public issues in any public forum or take part in organized action in support of causes or movements"77_ to nearly fire the reporter. ${ }^{78}$ Commenting on the general complaints that the AP receives about its coverage on the Israel-Arab issues, assistant foreign editor Ellen Nimmons (Appendix A, 19), whom I interviewed, says: "I certainly know that the Israelis complain to us every day." She says the Jerusalem bureau gets most of the complaints. "Occasionally I'll say can you ask such and such, and [Jerusalem] would say 'well [we] can ask and they will hang up on [us],' and I'd say 'ask anyway.'” As in 1982, American media coverage largely reflected their government's policies, which in 1982 was not very supportive of the invasion as it came to kill a vast number of civilians. Relations between Israel and America became tense when Israel only agreed to a ceasefire conditional on the PLO's departure from Beirut. Ariel Sharon, the architect of the invasion, was not popular in America, contributing to 
critical reporting about the war. But as we have seen, in 2006, U.S. media - including the AP - generally echoed American position by presenting the war as a just one because it was in response to the capturing and killing of Israeli soldiers on their side of the border. The U.S. was against an early ceasefire and at one point the Americans were accused of pushing Israel to prolong the war. Despite mounting deaths, U.S. President George W. Bush was pressing for a UN resolution linking a ceasefire with a broader plan for peace in the Middle East, and his Secretary of State Condoleezza Rice enraged the Lebanese when she likened the violence to the "birth pangs of a new Middle East." 79

Also, some of the Sunni Arab states and Lebanese Sunni and Christian leaders were happy to see Shia Hezbollah being attacked in $2006 .{ }^{80}$ In 1982, there were demonstrations against the war throughout the Arab world. In 2006, Saudi Arabia, Egypt, and Jordan blamed Hezbollah for recklessness in provoking the war. "There is a difference between legitimate resistance and miscalculated adventures," a spokesperson for the Saudi government said. ${ }^{81}$ King Abdullah of Jordan and then President Hosni Mubarak of Egypt warned that Hezbollah was dragging the Arab world into conflict through its misguided gambles and adventures. When the war dragged on and civilians were being killed, Arab states started to call for a ceasefire, says Interviewee I (Appendix A, 36).

While in 1982 Israeli peace movements had a significant effect on public attitudes and government policy, in July 2006, few Jewish Israelis opposed Olmert's war. From July 12 through early August, the "Peace Now" movement remained 
noticeably split, with many of its leaders and supporters - including such luminaries as the novelists Amos Oz and David Grossmann - expressing continued support for the war. $^{82}$

More importantly, by 2006 conflicts were framed in the $9 / 11$ context - as former IDF spokesman Shai Nachman acknowledged. ${ }^{83}$ The Israelis moved away their focus from the anti-Semitism argument to "war on terror."

We selected the [war on terror] instead of the second (anti-Semitism) because we are part of the Western world. We very much play the first argument. It's like if you've run out of arguments, you're stuck with anti-Semitism. The first one is based on common interests. ${ }^{84}$

Following the 2001 attacks on the U.S., says Philo (Appendix A, 20), Israel "made a strategic decision to turn all of the public relation over towards the war on terror. They already had quite a lot of good publicity going for them ... it wasn't that much different in terms of the exclusion of Palestinian perspectives or Arab perspectives before and after 9/11, but nonetheless it did give the Israelis a huge extra card to play and they played it very well, probably more in America than they did here [Europe]." ${ }^{.85}$

\section{Professor Robert Jensen agrees.}

Israel has made Americans empathize with its position by linking itself emotionally to Americans' 9/11 experience. Making a connection where there really isn't one. It's been breathtaking how American journalists have allowed themselves to be manipulated in this way. ${ }^{86}$ 


\title{
Endnotes
}

\begin{abstract}
1 Joseph Panossian, AP published in Desert News, "Hezbollah captures 2 Israeli soldiers in clashes, sparking Israeli offensive into Lebanon," July 12, 2006. http://www.deseretnews.com/article/640194197/ Hezbollah-captures-2-Israeli-soldiers-in-clashes-sparking-Israeli-offensive-into-Lebanon.html?pg=all. Also see: Steven Gutkin, AP published on NBC News, "Crisis allows Israel to pursue strategic goals, July 13, 2006. http://www.nbcnews.com/id/13847803/ns/world news-mideast n _ africa/t/crisis-allows-israel-pursue-strategic-goals/\#.U8rpioBdUUd. Aron Heller, AP published in Irish Examiner, "Israel suffers deadliest attack as rockets kill 15," August 7, 2006. http://www.irishexaminer.com/world/israel-suffers-deadliestattack-as-rockets-kill-15-10244.html
\end{abstract}

${ }^{2}$ Lieutenant Colonel Scott C. Farquhar, Back to Basics: A Study of the Second Lebanon War and Operation Cast Lead, ( Defense Department, 2009). http://www.cgsc.edu/carl/download/csipubs/farquhar.pdf

3 ibid.

${ }^{4}$ Helena Cobban, Boston Review, “The 33-Day War: Hizbullah's victory, Israel's choice," Nov. 2 , 2006.http://www.bostonreview.net/cobban-33-day-war

5 Joseph Federman, AP archive, "ISRAEL KEEPS SILENT ON MYSTERIOUS SUDAN

AIRSTRIKE," Oct. 25, 2012. http://bigstory.ap.org/article/israel-keeps-silent-mysterious-sudan-airstrike

${ }^{6}$ Cobban, op cit.

7 Sam F. Ghattas, AP published on Katu.com. "Israel continues to punish Lebanon, hits fuel supply," Jul 14, 2006. http://www.katu.com/news/3632791.html

${ }^{8}$ Ravi Nessman, AP published in Southeast Missourian, "Israeli troops raid Lebanon," Jul 13, 2006. http:// www.semissourian.com/story/1160085.html

${ }^{9}$ Human Rights Watch, "Why They Died", September 2007. http://www.hrw.org/pt/node/10734/section/10

10 Eileen Alt Powell, now retired AP Middle East correspondent. Email interview.

${ }^{11}$ GG Labelle, now retired senior editor. Email interview.

12 Hamza Hendawi, AP archives, “Hitting Hezbollah,” Jul 26, 2006.

13 Steven Gutkin, AP archives, “Olmert's Gamble,” Jul 14 19:16:30 2006.

14 Charles J. Hanley, AP published in Washington Post, “2 Key Americans See 1982 in Lebanon '06,” July 23, 2006. http://www.washingtonpost.com/wp-dyn/content/article/2006/07/23/AR2006072300210.html

15 Scheherezade Faramarzi, AP published in Washington Post, "Hezbollah Says Israeli Response a Surprise," July 25, 2006. http://www.washingtonpost.com/wp-dyn/content/article/2006/07/25/ AR2006072500974.html 
${ }^{16}$ Matti Friedman, AP published in Washington Post, "Plumbers Come to Rescue in Israeli Shelter," July 31, 2006. http://www.washingtonpost.com/wp-dyn/content/article/2006/07/27/AR2006072701046_pf.html

17 Aron Heller, AP published in Washington Post, "Northern Israelis Adapt to Life Under Fire," July 31, 2006. http://www.washingtonpost.com/wp-dyn/content/article/2006/07/31/AR2006073100540.html

18 Hussein Dakroub, AP archives, “Israel sends armored troops into Lebanon,” Aug. 1, 1006.

${ }^{19}$ Scheherezade Faramarzi, AP archives, "Night of Death,” Aug. 3, 2006.

20 AP, "Saving animals through 40 days \& nights of war in Lebanon \& Israel, September 2006. http:// www.animalpeoplenews.org/06/09/tsg.savinganimals09.06.htm. Donna Abu Nasr, AP published in Washington Post, "Famed Beirut nightlife shows resilience," July 22, 2006. http://www.washingtonpost.com/wpdyn/content/article/2006/07/22/AR2006072200543_pf.html

21 Cobban, op cit.

22 Layal Najib, a freelance photographer for Agence France-Presse, was killed July 23, 2006. She was hit by shrapnel from an Israeli missile while in a taxi on the road between the villages of Sadiqeen and Qana. She was trying to meet a convoy of villagers fleeing the Israeli bombardment of south Lebanon.

23 Amnesty International, "Document - Lebanon: Deliberate Destruction or 'Collateral Damage'? Israeli Attacks on Civilian Infrastructure," August 2006. http://www.amnesty.org/en/library/asset/ MDE18/007/2006/en/4c966a70-d3ff-11dd-8743-d305bea2b2c7/mde180072006en.html

24 AP published on Fox News "Israel: No Targets in Lebanon Are Immune," July 13, 2006, http://www.foxnews.com/printer friendly_wires/2006Jul13/0,4675,IsraelLebanonMilitary,00.html

25 ibid.

26 AP quoted Christian Berthiaume of the World Food Program in Geneva, Switzerland: "The Israeli forces were warning today, saying that there shouldn't be any vehicles in the southern part of Lebanon."

27 Peter Bouckaert, The Guardian, "White flags, not a legitimate target," July 31, 2006. http://www.theguardian.com/world/2006/jul/31/israelandthepalestinians.syria2. See also, AP printed in Fox News, "Israel: No Targets in Lebanon Are Immune," July 13, 2006. http://www.foxnews.com/printer friendly wires/ 2006Jul13/0,4675,IsraelLebanonMilitary,00.html

28 ibid.

29 Kathy Gannon, AP published in Washington Post, "Lebanese Find Destruction Back Home," Aug. 14, 2004. http://www.washingtonpost.com/wp-dyn/content/article/2006/08/14/AR2006081400821_pf.html

30 Todd Pitman, AP published in Washington Post, "Lebanese Father Mourns Loss of Family," Aug. 29, 2006. http://www.apnewsarchive.com/2006/Lebanese-Father-Mourns-Loss-of-Family/id-eld3f2e7ca6b594bc91988310e5d4f65?SearchText=\%20marwaheen \%202006;:Display

${ }^{31}$ Hamza Hendawi, AP published in Washington Post, "U.N.-Israel Encounter Highlights Discord," Sept. 29, 2006. http://www.washingtonpost.com/wp-dyn/content/article/2006/09/29/AR2006092900986_pf.html 
32 Ravi Nessman, AP archives, “Mideast Fighting,” Jul 28, 2006; Hamza Hendawi, AP archives, "Israel Targeting Hezbollah Infrastructure," Jul 26, 2006.

33 Habib Battah, "When Assumption Trumps Objectivity," Sept. 4, 2006. http://www.thecornerreport.com/ index.php?blog $=2$ \&page $=1 \&$ more $=1$ \&paged $=37$

34 ibid.

35 ibid.

36 Jonathan Spyer, The Global Research in International Affairs (GLORIA) Center, "Israel and Lebanon: Problematic Proximity," June 1, 2009. http://www.gloria-center.org/2009/06/spyer-2009-06-01/

${ }^{37}$ Hamza Hendawi and Lee Keath, AP story published in Free Republic, "Israel sends ground forces into Lebanon,” July 17, 2006. http://www.freerepublic.com/focus/f-news/1667025/posts

38 Hamza Hendawi and Lee Keath, AP story published in Free Republic, "Israel sends ground forces into Lebanon,” July 17, 2006. http://www.freerepublic.com/focus/f-news/1667025/posts

39 Ravi Nessman, AP published in Free Republic, "Israel OKs call-up of 30,000 reservists, Jul 27, 2006. http://www.freerepublic.com/focus/f-news/1673413/posts

40 Scheherezade Faramarzi, AP published in Washington Post, "Hezbollah's Fight Impresses Supporters," August 2, 2006. http://www.washingtonpost.com/wp-dyn/content/article/2006/08/02/

AR2006080200362_pf.html

41 Sam F. Ghattas, AP archives, "Lebanon Sees More Than 1,000 War Deaths, Dec. 28, 2006. http:// www.apnewsarchive.com/2006/Lebanon-Sees-More-Than-1-000-War-Deaths/id-82ccc1313d4332f45e2dc09f6bd44989

42 Cobban, op cit.

${ }^{43}$ Michael Totten, Michael Totten's Middle East Journal, “Terror War,” Aug. 18, 2006. http:// www.michaeltotten.com/archives/001240.html

44 Amnesty International, "Lebanon: Deliberate Destruction or 'Collateral Damage'? Israeli Attacks on Civilian Infrastructure," August 2006. http://www.amnesty.org/en/library/info/MDE18/007/2006

${ }^{45}$ Human Rights Watch, "Why They Died", September 2007. http://www.hrw.org/pt/node/10734/section/ $\underline{10}$

46 Kathy Gannon, AP published in Washington Post, “'Green Helmet' Helps Rescue the Wounded,” Aug. 11, 2006, http://www.washingtonpost.com/wp-dyn/content/article/2006/08/11/AR2006081101392.html

47 Jefferson Morley, Washington Post, “The Qana Conspiracy Theory," Aug. 12, 2006. http://blog.washingtonpost.com/worldopinionroundup/2006/08/the qana_conspiracy theory.html

48 Gannon, op cit. 
49 The proposed lead was sent by Sally Buzbee to the New York desk.

50 Sally Buzbee, AP archives, "Hezbollah May Have the Edge," July 30, 2006. http://www.apnewsarchive.com/2006/Analysis-Hezbollah-May-Have-the-Edge/id-9bc2c59e5313425cbf7a9082088453b5

51 Jonathan Cook, Al Jazeera, "Israeli war tactics criticized," Jan. 9, 2008. http://www.aljazeera.com/news/ middleeast/2007/12/2008525185248680582.html

52 Buzbee, op cit.

53 Edward W. Said, Covering Islam: How the Media and the Experts Determine How We See the Rest of the World (New York: Vintage Books, 1981) P. xi

54 Labelle (Appendix A, 13).

55 Sam F. Ghattas, AP archives, "Lebanon Sees More Than 1,ooo War Deaths, Dec. 28, 2006. http:// www.apnewsarchive.com/2006/Lebanon-Sees-More-Than-1-000-War-Deaths/id-82ccc1313d4332f45e2d$\underline{\mathrm{c} 09 \mathrm{f} 6 \mathrm{bd} 44989}$

56 Ghattas, op cit.

57 Internal AP memo.

58 Steven Gutkin was the Jerusalem bureau chief.

59 Arab Media Watch published by Electronic Intifada, "Associated Press refuses to explain its low Lebanese death toll," Dec. 14, 2006. http://electronicintifada.net/content/associated-press-refuses-explainits-low-lebanese-death-toll/3012

60 ibid.

61 ibid.

62 ibid.

63 Ellen Knickmeyer, Washington Post, "2006 War Called a 'Failure' for Israel,” Jan. 31, 2008. http:// www.washingtonpost.com/wp-dyn/content/article/2008/01/30/AR2008013000559.html

64 Ellen Knickmeyer, Washington Post, "2006 War Called a 'Failure' for Israel,” Jan. 31, 2008. http:// www.washingtonpost.com/wp-dyn/content/article/2008/01/30/AR2008013000559.html

65 Hamza Hendawi, AP archives, "Nasrallah's Popularity Climbs,” Sept. 25, 2006. http://www.apnewsarchive.com/2006/Nasrallah-s-Popularity-Climbs/id-da048352fd04c1028ed08a9a34ffb1db

66 Sally Buzbee, AP published in Desert News, "News analysis: Fighting could tip balance toward extremists," July 23 2006. http://www.deseretnews.com/article/640196964/Fighting-could-tip-balance-towardextremists.html?pg=all 
${ }^{67}$ Interviewee J (Appendix A, 37).

68 Charles J. Hanley, AP published in the Washington Post, "2 Key Americans See 1982 in Lebanon '06," July 23, 2006. http://www.washingtonpost.com/wp-dyn/content/article/2006/07/23/ AR2006072300210.html

69 AP published in USA Today, "Battles continue; Israel warns people to leave south Lebanon," Jul 21, 2006. http://usatoday30.usatoday.com/news/world/2006-07-20-israel-lebanon_x.htm

70 Interviewee I (Appendix A, 36).

${ }^{71}$ Greg Philo. Skype interview. Oct. 24, 2013.

72 ibid.

${ }^{73}$ Greg Philo and M. Berry M, More Bad News from Israel (London: Pluto, 2004).

74 Greg Philo, The Guardian, "What you get in 20 seconds," July 14, 2004. http://www.theguardian.com/ media/2004/jul/14/israel.middleeastthemedia

75 Philo. Skype interview, op cit.

76 The Jawa Report, The Subtle Anti-Israeli Biases of an AP Reporter, July 28, 2006. http://mypetjawa.mu.nu/archives/184103.php

77 Social Media Guidelines for AP Employees, May 2013. http://www.ap.org/Images/Social-Media-Guidelines tcm28-9832.pdf

${ }^{78}$ Based on general knowledge among AP staff.

79 Anne Gearan, AP published in South Coast Today, "Deal to end fighting won't help U.S. image," Aug. 13, 2006. http://www.southcoasttoday.com/apps/pbcs.dll/article?AID=/20060813/NEWS/

$\underline{308139977 \& \text { cid }=\text { sitesearch }}$

80 Elias Muhanna, Brown University professor. Email interview. Jul 20, 2014. Also see: The Daily Star, "Poll finds support for Hizbullah's retaliation," Jul 29, 2006: http://www.dailystar.com.lb/News/LebanonNews/2006/Jul-29/41696-poll-finds-support-for-hizbullahs-retaliation.ashx\#axzz3822AgHOo; Also see: Mai Yamani, The Daily Star, "Is Israel now the lesser enemy between some Muslims?" Jul 26, 2006. http:// www.dailystar.com.lb/Opinion/Commentary/2006/Jul-26/113053-is-israel-now-the-lesser-enemy-betweensome-muslims.ashx\#axzz3822AgHOo

81 New American Media, “Arab Regimes Back Israel's Attacks on Islamist Groups,” July 14th, 2006. http:// www.indybay.org/newsitems/2006/07/14/18288123.php?show_comments=1

82 Cobban, op cit.

83 See Philo interview in Chapter 4.

${ }^{84}$ Shai interview published in Philo and Berry, op cit. p. 249. 
${ }^{85}$ Philo. Skype interview, op cit.

86 Professor Robert Jensen Documentary, Peace, Propaganda \& the Promised Land: U.S. Media \& the Israeli-Palestinian Conflict, 2004 -http://www.youtube.com/watch?v=cAN5GjJKAac 


\section{Chapter 6: Conclusion}

This thesis set out to compare AP's coverage of the 1982 and 2006 wars that Israel waged against Lebanon to establish the changes that occurred during the years between them, and their possible causes and effects on journalism. In addition to technological changes, three major factors affecting the coverage were explored: the global "war on terror" narrative of post 9/11, when media bias and the binary narrative became more glaring and impenitent, reinvigoration of Israel's aggressive public relations (Hasbara) to improve its image and dominate the narrative following the 1982 invasion and the Sabra and Shatilla refugee camps massacre, and finally how AP's coverage reflected U.S. foreign policy and its relations with Israel. Other factors studied included AP's system of news reporting (including regionalization of the foreign bureaus), technological changes, and political and ideological pressures that impacted reporting.

The changes were reflected in the language, value-laden labels and phraseology to make "facts" fit the evidence; lack of context and history, and most importantly the egregious blurring of timelines (ignoring the cause and effect) - all contributed to the portrayal of the attacker as the victim and the victim as the oppressor. Questions of what happened, where and how were always asked, but rarely "why," at least not comprehensively and effectively, and if it was, it was usually in scattered long analysis pieces. This chapter wraps up the thesis with analysis of the findings and what the future holds for media coverage of war in the Middle East, and address the problems by providing alternative approaches to improve reporting. It will review the key 
explanations, analyses and findings from the voluminous research literature and journalistic examples provided in each chapter. It will analyze the interplay between the military and the media and the changing nature of warfare in globalized media:

censorship, propaganda and manipulation by the military and governments. As well, it will look at the new media that have entered the information domain, their shortcomings, but more importantly how they complement and strengthen future practices. Also in this segment, I will briefly look at what the AP did right and wrong in covering the two wars and how the three major factors mentioned contributed to the changes that we see today. Finally, I revisit the effects and transformation of Israel's Hasbara in its attempt to control mainstream media.

AP's importance lies in its large number of staff - more than any other American newspaper or broadcast network - stationed in more places than other news outlets. That amounts to serving as a tip service for big newspapers or broadcast networks on breaking news and even for in-depth analyses. The newspapers, in particular, could then do a fuller, more thoughtful story than the AP, which necessarily had to put together the story in bits and pieces for speed and, thus, had often exhausted itself, whereas the newspaper reporter might still have hours to put together the story at deadline. The AP may have set the news agenda for small or medium-size papers, and sometime for major ones, but that level of agenda-setting shrank as big newspapers and newspaper chains built their own news services (New York Times, Los Angeles Times, Washington Post, Gannett, etc.). The AP is still important in giving first word of a story as newspaper and broadcast staffs have shrunk, particularly overseas, in the current economic climate. But cable TV-channels, 
both American and foreign, have also taken over some of that job, as well as some websites. Also, as newspapers have given way to broadcasters or websites on delivering first word of a story, the print media have shifted to doing investigative reporting or overview analyses in which they, not the AP, set the agenda. ${ }^{1}$ As a cooperative "owned" by scores of newspapers, the AP has not historically had a corporate culture, although that has been changing in recent years. ${ }^{2}$

As we have seen, early 1980s were the pre-television age as far as getting the news. In Beirut, the AP had three or four radios on a radio monitoring desk, and the staff dialed back and forth between the state radio and the stations run by the various militias. ${ }^{3}$ Veteran Lebanese correspondent Farouk Nassar was the overseer of this operation, instructing the monitors what was and wasn't news, and usually writing the running story if something developed. The problem with the radio monitoring operation was that the various stations were notoriously inaccurate. It was up to Nassar to determine whether a radio report could be ignored, was worth checking out or could be used with attribution.

Technology in Beirut's bureau was rudimentary and technician Francois Ghattas, to save the operation from frequent electrical blackouts, had rigged a grid of $10 \mathrm{car}$ batteries that would support needed equipment - first the telex, later the computers - until someone could start the generator kept on the balcony outside the 4th floor office. Ghattas once managed to reverse the current and send enough power to the state telephone and telegraph company - which was suffering an electrical outage - so an AP story could be sent on to Cyprus. Ali Mahmoud, an Egyptian who was the AP bureau chief in Bahrain, said there was one Gulf newspaper that kept a picture of Ghattas over 
the AP teletype so it would not break down. The first computer gear arrived from London in the mid-' 80 s. ${ }^{4}$ In terms of news, the bureau in Beirut acted independently with little interference from New York and recruited some of the most versatile staffers and stringers to report on major events. Field reporting was the agency's strongest asset, with journalists "embedded" not with armed groups and armies, but civilians. Their first-hand reporting usually took precedence over other sources, including governments and the military, including the U.S. Marines and the Israeli Defense Force (IDF).

A gradual shift in reporting developed in the years following 1982, but it was too subtle to notice, even by reporters on the ground. As mentioned in the Introduction, I started working for the AP as a young journalist, taught the ropes by bureau chief Nicolas B. Tatro and his then wife, Earleen Fisher, who as my mentors insisted on accuracy above all, on reporting exactly what I saw without judgment. I still believe they taught me well and they reciprocated with their full trust in my professionalism and integrity as a journalist, who as an Iranian reporter found it only natural to report on my country as it was, even if I could be persecuted for my work. To me journalism should be above personal and ideological interests, and sometime above personal safety. Over time, however, I saw some slippage in AP's journalistic "standards" when focus was not always on the actual news but on what editors and American readers expected us to report. For instance, reporting - and amplifying - American or Israeli casualties took precedence over Lebanese or Palestinian casualties when U.S. Marines were deployed in Lebanon and Israeli troops occupied large parts of the country. Even when I became 
uncomfortable when labels such as "security zone" that were widely used in the mid-1980s, it did not dent my faith in my work and journalism in general.

The impact of Israel's Hasbara Project on the coverage was evident in the 1996 fighting between Israel and Hezbollah, though it was still far from what it is today. The biggest change came after 9/11 when not only the Israel-related coverage was affected but that of the whole of the Middle East and the Muslim world. The so-called "war on terror" became the watchword, and the AP willingly adopted it. The liberal use of Presidential George W. Bush's infamous phrase, "axis of evil” in reference to Iran became a common theme in AP copy. When I transferred to Lebanon in October 2006 to cover Iran's rising regional influence, I made it clear to editors that I did not want the label used in copy under my byline. The head of the Middle East Services agreed to take the reference out of an edited story ${ }^{5}$ had written. She explained her decision in AP's internal private message (Appendix C, 15) to a deputy international editor who had inserted the label in December 2006. She wrote while agreeing with my reluctance to use the phrase, it was necessary to make it clear on whose side the AP was. "I do think that since John $\mathrm{D}^{6}$ has asked Shaz ${ }^{7}$ to do everything she can to cultivate Iran sources so that we have some insight on them - it would be best to avoid "axis of evil" in this story, which is her first big one on Iran. I have inserted a substitute that gets very vividly (I hope) at Bush's criticism but also puts in Iran's side of the story. I do think it's going to be crucial for Shaz's stories under her byline to fairly give each side of the story, or she's going to be dead in water on source development efforts. I hope you understand that this 
DOES NOT in any way mean we kowtow to Iran ... not at all. Shaz has long track record of good, tough reporting and she and I are in complete agreement on this."

As we have seen in previous chapters, with the dawning of the new millennium, at first there was a noticeable change in language, in the way Arabs and their actions were described (inflammatory), and the way Israelis and their actions were depicted. Priority and maximum space was commonly given without challenge to Israeli views and proIsraeli commentators. Lack of context in describing violence became more salient, as did the blurring of responsibility: an inability or lack of will to correctly define causes and effects. "Israeli attacks and military actions, the Israeli emphasis on security, was all a retaliation" $"$ to Lebanese or Palestinian violence, "a reaction to a phenomenon that was never properly explained" - or explained enough - consequently giving the impression that the Lebanese or Palestinians had asked for the Israeli attacks and killings. Colorful description or detail of the killings were usually absent, while a great deal of care and space were usually afforded to portray the plight of the Israeli victims. Timelines were out of sync, making it difficult to determine whose response was to whose initial attack. Emphasis was generally on the idea that Israel, as a proper state with a democratic government, was trying to defend itself in its fight against "terrorism." imbalance of power between the two sides: a state and an army with huge American backing and weapons and a guerrilla group either under military occupation or threat of attack, were rarely explained.

Greg Philo, a leading academic from Glasgow University, and his team of analysts and researchers address this failure very well as we have seen in Chapter Four. In 
their definitive work on television and radio coverage of the Israel-Palestinian conflict, they also found that even when certain important events, such as the breaking of a ceasefire or a siege are reported, they appear "as confused, scattered moments and oblique references."10 (The same held true with the AP coverage.) The contrary perspective that militant groups were responsible for starting the violence "occurs as a consistently and clearly stated theme..."11- even though the violence is not that of "siege, deprivation, death and destruction, but the odd and usually harmless rocket - which of course, naturally, brings the inevitable Israeli response." 12

As explored in previous chapters, part of this reporting process dehumanizes the Arabs, the other. Lebanese or Palestinians are never "kidnapped" by Israel but imprisoned, while Israelis held by Arabs are often referred to as being "kidnapped;" they also have names and their faces usually become familiar to audiences. The widely used labels of Islamic militants trigger in the Western mind dangerous religious fanatics. Perhaps Shirine Tadros, an Egyptian and former correspondent for Al-Jazeera television who reported on the war in Gaza in November 2012, explains best why the coverage is flawed:

The need to sanitize events so as not to be controversial and upset the wrong people, the lack of humanizing the conflict for fear that it will make you look sympathetic or worse empathetic to the Palestinians, which could be career suicide...

The thing journalists seem to be struggling most with right now is what constitutes a legitimate target. A house with 10 family members, including kids, women and old people is struck with a missile. They all die. There is initial outrage. But then the Israeli army says it was targeting a 'Hamas official.' Suddenly the coverage is different. The line about the Hamas official is put into every script without question or 
context - all is well now because initially the story seemed unbalanced, too risky to report because it sounded too bad to be true. ${ }^{13}$

Noam Chomsky (Appendix A, 4) also takes issue with journalists - and some scholars - who accept the authority line without challenge or skepticism. "It would be impossible for the media to simply review the facts," ${ }^{14}$ he says in reference to America's double-standards when it comes to Israel. "The fact that nobody even notices there is something funny about it, that shows you the profound level of indoctrination. Not only here, but in England and Europe generally. There is a deeplyrooted Imperial mentality which simply cannot see the world. ... It's so transparent. You have to be kind of intentionally blind not to see it." 15 French intellectual and scholar Francois Burgat, ${ }^{16}$ who warned of the dangers of Western blindness to colonial Middle Eastern history, contended that two main types of intellectuals dominate the region's narrative - the "negative intellectuals" who echo state interests, and "the facade intellectuals," who confirm their already-held notions, beliefs, preconceptions, and racisms regarding the "other." According to reporter Nir Rosen, mainstream journalists, as well as their local interlocutors, often fall into both categories. The Middle East, he says, "is an exceptionally suitable place for the Western media to learn about itself and its future, because it is the scene where all pretensions of objectivity, neutrality towards power, and critical engagement have faltered spectacularly." ${ }^{17}$ It is also where journalism simplifies - "de-historicizes;" journalists "take reality and amputate it, contort it, and fit it into a predetermined discourse or taxonomy. The American media always want to fit events in the region 
into an American narrative," writes Rosen. "Islam is also treated like a code that can be unlocked, and then locals can be understood as if they are programmed only through Islam." And, "all too often, it just comes down to "what does this mean for Israel's security?" It is difficult "to portray Arabs and Muslims as the good guys unless they are "like us." "18

This, he wrote, is not just the journalists' fault, but "driven by American discourse which drives the editors back in New York and Washington. ... I once asked my editor at The New York Times Magazine if I could write about a subject outside the Muslim world. He said even if I was fluent in Spanish and an expert on Latin America, I wouldn't be published if it wasn't about jihad." 19

This assessment rings true with an incident on June 3, 2010, when a few thousand people rallied outside the UN headquarters in Beirut to protest an Israeli naval commando raid three days earlier on an aid flotilla that was carrying humanitarian aid for Israeli-besieged Gaza. Nine people were killed in the raid in international waters in the Mediterranean Sea. AP's deputy Middle East regional editor, who was visiting Beirut from his base in Cairo, returned from the rally unable to control his excitement (Appendix C, 16): he had spotted a toddler in the midst of the big crowd wearing a mock suicide vest - irrelevant to the seriousness of the rally. The AP photos of the toddler of course made a huge splash on the internet, with antiMuslim bloggers using it as proof of Muslims' innate violent nature. "Photo of the Day: How Muslims Celebrate HAMAS Flotilla Terrorism," was the headline of Debbie Schlussel's blog. ${ }^{20}$ The sensational and out-of-context use of the toddler's 
photographs not only made a negative value judgment on an entire crowed that was peacefully demonstrating against a legitimate cause, it also sheds light on the extent of ignorance and perhaps "indoctrination" of reporters since $9 / 11$; or perhaps a drive to attract audience.

We have seen in previous chapters that many of the AP reporters - especially copy editors - were unaware of the existence and possible effects of much of the value-laden language, blurred timelines or lack of context in AP copy. Others who were aware, felt constraints placed on them either from senior editors, AP boilerplates, ${ }^{21}$ or outside pressures, including governments. One journalistic slip, according to Donna Bryson Bryson (Appendix A, 3) is that "reporters too often repeat what other reporters have written without questioning or doing their own reporting. ... Reporters don't question their own language enough, and that might be a matter of professionally shared values.... Our sense of what a journalist is, developed at university and in the workplace, is probably more to blame for conformity in the industry than the 'power' of top editors and an organization's culture."

Could the problem lie in journalism schools especially when some professors who question the feasibility of objective journalism settle for "imperfectionism" (as proposed by Stephen Ward and discussed in Chapter Two)?22 At a time when journalism is suffering from an unprecedented credibility problem, the solution to its ills is not to seek imperfection, but to perfect the imperfections, or at least improve them. The goal should be the "Truth," not a semblance of truth. To settle for imperfection because it reduces expectations, and to call for non-absolute forms of 
inquiry, is to set the bar very low. It is a disservice to journalism and the public. It is also a disservice to good journalists who have maintained excellent standards for many years despite all kinds of challenges - it is called journalistic integrity. Integrity means being fair, not losing sight of the bigger picture, not hiding behind the distorted concepts of "objectivity" and "balance." Journalistic integrity is when journalists report fairly and intelligently about something or someone they may personally disagree with. Good journalism is when patriotism, ideology, and religion are left at home. It is when a journalist does not bend under pressure whether for personal gains or weaknesses. None of this is too difficult. It is time to make it better, perhaps learn from those who have maintained the standards. Better journalism is achievable as long as journalists do not settle for the mediocre. There are many good journalists who try to do their job professionally. Many others have unfortunately quit in protest because of too much constraint. It is a struggle and hard work for those who stay, and it takes a great deal of personal sacrifice.

Covering the Middle East is more constrained because of popular forces, including very organized groups such as AIPAC (The American Israeli Public Affairs Committee) that have tremendous influence over the media in making sure they toe the Israeli line. What is commonly called the Lobby, is the most powerful element in the PR drive. Its influence in American political and journalistic circles "is great and insidious," says veteran and former BBC Middle East correspondent Tim Llewellyn, author of the authoritative book on Lebanon, The Rise of Phoenix: Beirut and the Story of Lebanon. ${ }^{23}$ "The Zionist propagandists are skilled at terrifying, penetrating 
and cajoling" the media in America and Britain, he says. "These manipulators have a knack like no other lobbyists of knowing whom and where to strike, and when, and they can be objectionable and personal when required," according to Llewellyn, ${ }^{24}$ whose assessment of the influence of Israeli public relations on the BBC, could also apply to the American media; it also resonates with the views of many former and current AP journalists interviewed for this thesis. In a lecture he gave in April 2014, Llewellyn explained the reasons why the $\mathrm{BBC}$ has cowed under pressure, and outlines the dynamics of its relationship with the Lobby - which again could apply to most mainstream media, including the AP:

Most BBC executives ... yearn for a quiet and trouble-free life - their policies are largely to avoid and avert trouble and confrontation, not meet it head on and certainly not seek it. The soft answer turns away wrath, and compliance with these awkward but powerful pro-Zionist customers is much preferable to accusation and abuse, the bottom line of which can be that epithet that all British great and good fear most, that of anti-Semite, which is more and more broadly used by Israel and its fans these days to characterize anything that seems to contradict or criticize Israel's methods and interests. ${ }^{25}$

The constraints, however, go beyond the Lobby, and is also rooted in racism and indoctrination, which is "of the accidental rather than the deliberate kind, but nonetheless effective for that." ${ }^{26}$ Llewellyn (Appendix A, 14) provides a sweeping analysis in an interview for this thesis of the journalists' mindset (and psychology) in covering the Middle East that also resonates with some of the comments of AP's American journalists. His insight thoroughly reflects the dynamics of media coverage: 
There still lurk in our British perceptions and perspectives our fears and ignorance of 'the other,' of for example Islam, of Muslims, of Arabs, a hangover perhaps from our history books and the stories we heard in our infancy. My generation, and even that of my children, were to some extent still products of an Imperial and post-Imperial education system - if the red had disappeared from the Map of the World, the spirit that had informed it, the stories of war and conquest and derring-do, of Kipling, Rider Haggard, the Charge of the Light Brigade, the marching boots of Wellington's armies, the flotillas of Francis Drake and Walter Raleigh, the escapades of Lawrence of Arabia, these were presented to us heroically in lesson, in film, on TV and radio. ${ }^{27}$

Many of the "Empire's glories" and attitudes continue to linger on, says

Llewellyn. "They still color our background pinkish, if not red," even though many educated people of his generation had questioned them. "The virulent popular press, many of our politicians and, at times, the broadcasters, reflect this rosy hue," he says, adding that the news media still tend to trust the official word, "the steady reasoning of the state and our glorious history to back it." Even journalists of different ethnic backgrounds who enter the workforce are influenced by these attitudes and are inclined to go with the flow. "The institutional thinking might well be the watchword for them, as it seems to be for many senior journalists and executives who know, or should know, better - but jobs are hard to come by these days." 28

Llewellyn explains why Americans specifically are ill-informed about the Middle East. Is it nurture, distance or the media? American news, he says, is geared to the U.S. and since Israel is seen as a strategic ally, the American narrative is sympathetic to it.

Underlying all this is racism, Israelis are 'people like us.' They go to supermarkets, wear bikinis, drive hatchbacks and SUVs, eat rice 
crispies and - largely - speak English (those that are seen on TV) and they have 'our values.' They are white (Arabs are 'brown.'). They don't wear headscarves and tea-towels and they don't carry bodies wrapped in sheets to the graveside wailing and chanting incomprehensibly. Their young soldiers in uniform carry guns, like ours do, but not young lads in masks and/or civilian clothes. They have a parliament, like Europeans, and a Prime Minister, and these guys wear suits and ties, whereas Palestinians who wear suits and ties are rarely shown and their parliament or elections are rarely mentioned. The perception of Arabs is that they are not 'people like us.' They are Muslims, which is a bit weird, and do not react to events as we do. They are excitable, where we are cool, out of control, where we are disciplined, disorderly, where we are law-abiding.

He lists all other reasons why Westerners identify with Jews (by association with Israel): they are educated, witty, have a major presence in the arts -music, films, and literature. They are also university professors, judges, lawyers, doctors, psychologists, dentists, surgeons, philanthropists, philosophers, mayors, and politicians. On the other hand, says Llewellyn, Arabs are seen in the West as being "a mess, basically, ill-disciplined, failures, lacking in culture or balance and deeply menacing" - as stereotyped in Hollywood and on television.

Arabs work in grocery stores and garages, or on assembly lines in Detroit. This is the perception that is background to and underlies the way Israel and the Middle East is presented. The media rarely try to explain to Americans WHY Arabs and Iranians resent the U.S., why they behave the way they do. It's just irrational, innately wild behavior. You'll recall in Iran in 1979 all the networks ever showed was hordes of veiled women and angry young men shouting out 'Death to America' and burning Stars and Stripes. No one was in the business of telling America about Savak, ${ }^{29}$ Persian culture, the Shah's Westernization program, the corruption and inequities he presided over, the vulgarity, the torture, the insult to Iranian people, Mossadeq, ${ }^{30}$ British Petroleum, and so on. No one even at the BBC any longer puts Gaza in any sort of context. It's those wild ... firing 
rockets because that's what they do, those pesky Arabs, they shoot at nice civilians in their neat homes and in their neat school buses and VW Golfs. It is all of a piece. Take away the history and the context, the 65 years of Gazan refugees in mounting squalor, under siege, 'on an Israeli diet, ${ }^{31}$... take away that, and the daily Israeli shootings, bombings, restrictions, free-fire zones and ceasefire violations, keep misquoting Hamas, and all you are left with is irrational and out-ofcontrol, murderous Middle Easterners. The Israeli Lobby doesn't need to do much. ${ }^{32}$

As we saw in Chapter Two, Israel invaded Lebanon under the pretext of an assassination attempt on its ambassador in London and stopping cross border PLO attacks even though the Palestinian group had not violated the ceasefire for 11 months. Yet Israel's narrative was repeated across the political spectrum among American intellectuals, both right and left. Even today, it is the reason given for the 1982 war. "The myth was born that it was preceded by daily shooting," wrote leftist Israeli writer Uri Avneri or the 1982 invasion. “Today, almost every Israeli can 'remember' the shooting an astonishing example of the power of suggestion." 33 Israel's "right" to "self-defense" even at the cost of thousands of civilian lives has been defended even by those who have fought and spoken for the of innocent civilians throughout the world - from Vietnam to South Africa to Native Americans. Actress Jane Fonda, whose campaign against civilian suffering in North Vietnam gained her fame - and notoriety - toured Israel and Lebanon at the height of the war in July 1982, declaring solidarity with Israel in its "struggle against Palestinian terror." 34 Fonda's human compassion for one set of innocent victims but not other equally innocent victims, was nothing new. Take the still-idolized journalist Martha Gellhorn whose powerful portrayal of the suffering of civilians in Vietnam and compare 
it to her racist and condescending references to Palestinians. Gellhorn regarded

Palestinian refugees with contempt as she explained in a 1962 article in The Atlantic:

The fancy word we use nowadays is 'empathy' - entering into the emotions of others. I had appreciated and admired individual refugees but realized I had felt no blanket empathy for the Palestinian refugees, and finally I knew why... It is hard to sorrow for those who only sorrow over themselves. It is difficult to pity the pitiless. To wring the heart past all doubt, those who cry aloud for justice must be innocent. They cannot have wished for a victorious rewarding war, blame everyone else for their defeat, and remain guiltless. Some of them may be unfortunate human beings... But a profound difference exists between victims of misfortune... and victims of injustice. My empathy knew where it stood. ${ }^{35}$

Gellhorn's position on Israel and the Palestinians is emblematic of many of the leftist and liberal European and North American intellectuals. It is a puzzling stance to many Middle Eastern intellectuals: Why when most of the liberal giants - such as JeanPaul Sartre, Michel Foucault, Étienne Balibar, Pierre Bourdieu and Slavoj Zizek among others have voiced public anger and protested against racism, white supremacy, Nazism and South African Apartheid, are opposed to colonialism, old and new - have they no compassion and sympathy for Palestinian victims of Israeli occupation and violence? As Edward Said ${ }^{36}$ maintained, the impunity with which Arabs and Muslims are disparaged would be unacceptable in mainstream discussion about Africans, Jews, or Asians. But why? Columbia University professor Joseph Massad believes it is because leftists "continue to hold on to a pristine image of a Jewish State founded by Holocaust survivors rather than by armed colonial settlers." Their status as colonizers, who have used "racist colonial violence for the last century against the Palestinian people, is a status they refuse to recognize and continue to resist vehemently." ${ }^{37}$ 
Bourdieu, a French philosopher, explained this contradiction in a 2000 interview with the Revue d'etudes palestiniennes: "I have always hesitated to take public positions... because I did not feel sufficiently competent to offer real clarifications about, what is undoubtedly, the most difficult and most tragic question of our times (how to choose between the victims of racist violence par excellence and the victims of these victims?)"38

According to Massad, some Western leftist-socialist intellectuals reiterate the false notion that Hitler is a hero in most Arab countries and that The Elders of the Protocols of Zion ${ }^{39}$ and other anti-Semitic myths are found in Arab primary school textbooks, a misconception that Martha Gellhorn may have also been influenced by. ${ }^{40}$ Israel's image as the only democracy in the Middle East could also be a factor in shaping such attitudes, as well as Islamophobic bias - the myth that Arabs who resist occupation are more driven because of Islam's rejection of Jewish “cosmopolitanism,” and "modernity," a familiar rhetoric used by George W. Bush to mobilize support for his "war on terror" following $9 / 11 .{ }^{41}$

Chomsky contends that the left in America, including the Labor Union, strongly supported the 1982 invasion, as did most conservative columnists.

At the extreme left of mainstream politics, support for the invasion was no less fervent. The Santa Monica City Council, regarded as virtually a socialist enclave, passed a resolution 'in essence, to support the right of Israel to defend its borders by invading Lebanon.' 42

Daniel Pipes explains that America's “inexhaustible fascination” with Israel derives equally from theology and history. Jews were the only non-Christians that 
Europeans encountered through most of medieval and modern times. "As a conspicuous religious minority with a crucial role in Christian theology, the Jews have always been disproportionately prominent in Europe." ${ }^{\prime 3}$ The U.S. inherited this European interest in Jews and Israel inherited the conspicuousness attached to the Jewish people of Europe. However, Pipes adds:

Whereas the Jews of Europe attracted attention by being different, the Jews of the Middle East, ironically, attract attention by being familiar. Israel, founded by settlers coming from Europe, is the most Western nation of its region. Consequently, to an American, it is the most comprehensible country in the Middle East. ${ }^{44}$

This pattern has remained unchanged despite the growing number of Middle Eastern Jews who have become a majority in Israel because "the dominant political culture remains the one established by the pioneers early in the century," said Pipes. Hence, because of "the drama of its birth, the resurrection of Hebrew, the ingathering of Jews from around the world, the age-old religious associations of the land, Israel commands disproportionate attention from the American media. ${ }^{945}$ However, one could argue that if familiarity, common culture, history, and theology are the reasons why intellectuals feel no empathy for victims of Israel's oppression, then why are they not beholden to the same criteria when it comes to victims of America's violence (Vietnam), or of the white European Apartheid regime in South Africa?

The Middle East and other parts of the Islamic world, especially since 9/11, have provided Western reporters with the best opportunities to make it big in the industry. Many with stints there have returned with big promotions, gone on to win awards and write books. ${ }^{46}$ But not all these reporters understand the complexity of the region that 
many do not even speak its languages or have done any substantial reading on it. A scant few - not more than half a dozen - of the army of journalists who cover the area speak Arabic, even though they consider themselves experts on the region, its culture and religion. How can they understand the suffering of a mother who wants to tell them how the death of her son has destroyed her, or understand the trauma of a child who witnessed the killing of her father and siblings at a Baghdad intersection by American soldiers, or by Israeli shellfire in a Lebanese village? Can a translator really do justice? There is supposed to be a connection between the reporter and the subject, that connection is the magic of being a journalist. Seymour Hersh believes the malady of journalism lies in the fact that journalists today are more interested in winning awards. "It's journalism looking for the Pulitzer Prize." ${ }^{47}$ Veteran British journalist Robert Fisk advises "every journalist in the Middle East needs to walk around with a history book to remind him or her of why we got to where we are; why the injustices and horrors of yesteryear are engraved in the people's minds and why they have a powerful influence on what happens next." 48 Based on these pieces of evidence and anecdotes, one can strongly argue that quality journalism is under threat and the future looks gloomy for the profession. Considering the past years in which we have witnessed traditional print and broadcast outlets hemorrhaging their audiences, there is much to be gained from examining alternatives to traditional media, as the multiplicity of views is greater today, with the number of tweeters, bloggers and special interest web sites. It is true, as academic James Curran, ${ }^{49}$ points out, that traditional news media are not faced with an apocalypse, but there is hope that they will be much more accountable with the advent of social media. 
Robert McChesney asks if the internet will set us free. ${ }^{50} \mathrm{My}$ answer is that the internet is perhaps one of our best hope in the short run, or at least a major step toward dismantling the corporate grip on our media, the economy and politics as a whole. McChesney is not so optimistic, however, because, as he states, a wave of mergers between traditional media and telecom firms with internet and computer firms have already taken place. Financial considerations are a hindrance, to say the least.

Yet, over the years since McChesney's study in 2001, bloggers, tweeters and writers have used the social media not only to inform the public, but are also acting as a watchdog of mainstream corporate media. According to Curran, the rise of the web enables people to answer back: hold the media to account, to verify or falsify its claims and provide a counterweight to its oligopolistic power. It was bloggers who drew attention to the inaccurate AP "Hiroshima" nuclear claim (see Chapter One). Had it not been for the internet, Facebook and other social media outlets, the scientists' response would most certainly not have been publicized as it was, which was picked up by every social media organ with calls for accountability. In the end, the AP made some adjustments to the story. It marked one of many times when bloggers successfully challenged news values and in the process redefined what was acceptable and unacceptable. It is hoped that gatecrashers, as Curran ${ }^{51}$ refers to the legions of bloggers, citizen journalists and web-based start ups, will be watching mainstream contents very closely. Unless journalists take heed of Chomsky’s advice (and others), journalism will probably continue the same path: "We call on journalists around the world working for corporate media outlets to refuse to be instruments of this systematic policy of disguise. 
We call on citizens to inform themselves through independent media, and to voice their conscience by whichever means is accessible to them." ${ }^{52}$ Had it not been for the internet and blogs we may well not have seen such pleas and other good work by Chomsky, who has been a media critic for a very long time and has written several books on the subject, but his reach and his impact have become much wider and stronger since the advent of the internet.

James R. Compton and Paul Benedetti ${ }^{53}$ blame the rise of social media on the failure of traditional news organizations to provide sufficient coverage of, among others, government war propaganda in the runup to the invasion in Iraq. While I agree - and disagree - with many of the studies and academic papers on the future of journalism, the problem I have with those I have seen is that they rarely, if at all, touch on the work of journalism itself and instead focus on the threats or advantages of the technologies that have been springing up. Compton and Benedetti ask how autonomous is the work of reporting likely to be in the wake of massive layoffs. My question is, how autonomous was it before the explosion of the social media? When 9/11 occurred, Americans were shocked into asking, "why do they hate us?" Some scholars ${ }^{54}$ have blamed the media the vast armies of foreign correspondents - for not informing the public of the changing landscape in the Middle East and the negative influence of American foreign policy on that region and beyond. Before $9 / 11$, we were not in a "chaotic moment in journalism" as the Compton and Benedetti describe the current "crisis." Journalists were not under pressure to produce more, in less time, as a consequence of newsroom redundancies, and the work generated by websites established by traditional news media, requiring stories to 
be updated in a round the clock news cycle. So how come journalism suffered from "creative cannibalism" then?

The rise of various social media outlets, in my opinion, is unavoidable and not necessarily a threat to journalism. It is a normal evolution of the media. If the function of "gatecrashers," is to provide better context and make traditional journalism accountable, then power to them. According to Chomsky, had it not been for Facebook postings during the 2012 Israeli attacks on Gaza, "we would not be aware of the degree of terror felt by ordinary civilians in Gaza. This stands in stark contrast to the world's awareness of terrorized and shock-treated Israeli citizens. Apparently such scenes are not newsworthy for the New York Times, the CBC, or the BBC." ${ }^{55}$ On his website, Chomsky provided extensive analysis and perspective on the war, the history of the Israeli-Palestinian conflict that dates back to decades. Before journalists and editors cry wolf, they ought to take a very good and reflective look at their work. If standards remain so low, with or without new tools, journalism will become almost irrelevant.

Despite the discouraging picture of consistent media "misconduct," we should not give up hope in improving the profession. To ensure that journalistic integrity is not compromised further, journalists and scholars ought to learn the lessons of the rampant violations of ethics, especially in our coverage of the Middle East. Journalism must not allow itself to be easily manipulated by governments and the military. It should not be their mouthpieces in their drive to further their agendas. When the media become complicit - whether knowingly or unknowingly - the casualty is the truth. Journalists should be held accountable, just like in any other profession. It is not possible to go back 
and change what happened in the past, but future journalists can do a better job capturing the complexities of world affairs. This is particularly important in today's world where journalism is distrusted or seen as irrelevant. Perhaps there is light at the end of the tunnel - even as news organizations continue to slash budgets. Online journalism could lead the way, though corporations already are pouncing on and buying off the successful ones. It is not only journalists who should grab this opportunity, but also scholars and the public. The public needs to become more engaged and aggressive in demanding critical journalism and not be too accepting and complacent.

Another light is the increasing number of American and European journalists of Middle Eastern background employed by major mainstream media outlets. Unlike their predecessors who were afraid to "rock the boat" for fear of being branded anti-American or anti-Israel, or worse, pro-Hamas, pro-Hezbollah, or pro-Iranian regime, these young journalists are making valuable contributions to today's journalism in challenging the old media narrative about the Middle East. They are less intimidated by the pressures. More importantly, they understand Western society, culture and media better than local staffers working in various bureaus around the world and are more able to work around the de facto Western narrative.

Also, journalism schools' international reporting curricula would better serve the future of the profession if they made it a requirement for students who plan to cover foreign news to learn at least one major foreign language and take courses in the history, literature and culture of a couple of parts of the world where they may want to focus on. Teaching students only reporting and writing techniques is apparently not enough. ${ }^{56}$ 


\section{Endnotes}

${ }^{1}$ GG Labelle (Appendix A, 13).

2 Donna Bryson (Appendix A, 3).

${ }^{3}$ Memo from G.G. Labelle on Feb. 2, 2005 to management in New York.

${ }^{4}$ ibid.

${ }^{5}$ Scheherezade Faramarzi, AP published on Highbeam Business, "Iran stands as a power in Mideast," Dec. 10, 2006. http://business.highbeam.com/435553/article-1G1-155721246/iran-stands-power-mideast

${ }^{6}$ John Daniszewski, AP international editor.

${ }^{7}$ Shaz is short for Scheherezade (Shahrzad Faramarzi).

8 Tim Llewellyn, "The BBC Bias: Firmly in the Arms of Zion, Media talks at Nottingham (March 15) and Istanbul (April 22-23), 2014. Transcript of the lecture provided by Llewellyn.

${ }^{9}$ Greg Philo and M. Berry M, More Bad News from Israel (London: Pluto, 2004).

10 Greg Philo and M. Berry M, More Bad News from Israel (London: Pluto, 2004).

11 ibid.

12 Llewellyn, op cit.

13 ibid.

14 Noam Chomsky. Personal interview. Cambridge, MA, May 2009.

15 ibid..

${ }^{16}$ François Burgat, Islamism in the Shadow of Al-Qaeda (Texas: University of Texas Press, 2008) p. 134.

17 Nir Rosen, Al Jazeera.com, "Western media fraud in the Middle East," May 18, 2011. http://www.aljazeera.com/indepth/opinion/2011/05/201151882929682601.html

18 ibid.

19 ibid. 
20 Debbie Schlussel, "Photo of the Day: How Muslims Celebrate Hamas Flotilla Terrorism,” June 3, 2010. http:/www.debbieschlussel.com/22793/photo-of-the-day-how-lebanese-other-muslims-celebrate-hamasflotilla-terrorism/

21 Boilerplate is any text that is or can be reused in new contexts or applications without being greatly changed from the original.

22 Stephen Ward, The Invention of Journalism Ethics: The Path to Objectivity and Beyond, April 2006. http://www.mqup.ca/invention-of-journalism-ethics--the-products-9780773528116.php

23 Tim Llewellyn, Spirit of the Phoenix: Beirut and the Story of Lebanon (London: I.B. Tauris, 2010).

24 Tim Llewellyn, "The $B B C$ Bias: Firmly in the Arms of Zion, Media talks at Nottingham (March 15) and Istanbul (April 22-23), 2014. Transcript of the lecture provided by Llewellyn.

25 ibid.

26 ibid.

27 ibid.

28 ibid.

29 The Shah's secret service.

30 Iranian Prime Minister Mohammad Mossadeq was overthrown in a CIA-engineered military coup in 1953.

31 Reference to Israeli blockade of Gaza since 2007.

32 Llewellyn. Email interview. Dec. 5, 2012.

33 Uri Avneri, “The War of Lies,” Jan. 7, 2012 - http://zope.gush-shalom.org/home/en/channels/avnery/ $\underline{1339170910 /}$

34 Noam Chomsky, Fateful Triangle: Israel, the United States, and the Palestinians (Montreal: Black Rose Books Ltd., 1984) p. 268.

35 Martha Gellhorn, The Atlantic, "The Arabs of Palestine,” October 1961 - http://www.theatlantic.com/ magazine/archive/1961/10/the-arabs-of-palestine/304203/?single page $=$ true

36 Edward Said, Covering Islam: How the Media and the Experts Determine How We See the Rest of the World (New York: Vintage Books, 1981).

37 Joseph Mossad, "Sartre, European intellectuals and Zionism, The Electronic Intifada, 2003 - http://electronicintifada.net/content/sartre-european-intellectuals-and-zionism/4384

38 ibid. 
${ }^{39}$ The tract, fabricated by the secret police of the Czar, purported to expose a sinister conspiracy of the Jews to rule the world. See also Encyclopedia Britannica, http://www.britannica.com/EBchecked/topic/ 480269/Protocols-of-the-Learned-Elders-of-Zion

40 Odd supposition; I read the Diaries of Ann Frank in primary school in Kuwait; most of the movies about the Holocaust and Exodus are shown in cinemas and on television in the Middle East.

${ }^{41}$ In his address to Joint Session of Congress following the 9/11 attacks, George W. Bush said: “Americans are asking, why do they hate us?... They hate our freedoms - our freedom of religion, our freedom of speech, our freedom to vote and assemble and disagree with each other." http://www.americanrhetoric.com/ speeches/gwbush911jointsessionspeech.htm

42 Chomsky, op cit. p. 266.

43 Daniel Pipes, New Republic, "The Media and the Middle East," Aug. 2, 1982. http://www.danielpipes.org/166/the-media-and-the-middle-east

44 ibid.

45 ibid.

${ }^{46}$ See for example, Kim Barker, The Taliban Shuffle: Strange Days in Afghanistan and Pakistan (New York: Anchor Books, 2012); or Dexter, Filkins The Forever War (New York: Vintage Books, 2009).

${ }^{47}$ Seymour Hersh, The Guardian, "On Obama, NSA and the 'pathetic' American media," Sept. 27, 2013. http://www.theguardian.com/media/media-blog/2013/sep/27/seymour-hersh-obama-nsa-american-media? $\underline{\mathrm{CMP}=\text { twt gu }}$

48 Philip Knight and John R Bradley, The New Zealand Herald, "Mixed reviews for Robert Fisk's The Great War for Civilization," Oct 28, 2005. http://www.nzherald.co.nz/lifestyle/news/article.cfm? c id=6\&objectid $=10352337$

49 James Curran, Media and Power (Communication and Society), (New York: Routledge, 2002).

${ }^{50}$ Robert McChesney, Rich Media, Poor Democracy: Communication Politics in Dubious Times, (New York: The New Press, 1999).

${ }^{51}$ Curran, op cit.

52 Maureen Clare Murphy, Electronic Intifada, "Linguists including Noam Chomsky condemn 'reprehensible' Gaza coverage," Nov. 14, 2012. http://electronicintifada.net/blogs/maureen-clare-murphy/linguists-including-noam-chomsky-condemn-reprehensible-gaza-coverage

53 James R. Compton and Paul Benedetti, Research Gate, Labour, New Media and the Institutional Restructuring of Journalism. August 2010. http://www.researchgate.net/publication/ 232986489_LABOUR_NEW_MEDIA_AND_THE_INSTITUTIONAL_RESTRUCTURING_OF_JOURNALISM 
${ }^{54}$ For example, Rosen, op cit.

55 Rabble.ca, "Nous accusons: Mainstream media fails to report on atrocities against Gaza" Nov. 14, 2012. http://rabble.ca/news/2012/11/nous-accusons-mainstream-media-fails-report-atrocities-gaza

56 Karim H. Karim cites in his book, The Islamic Peril: Media and Global Violence (Montreal: Black Rose Books, 2002) a review on journalism curriculum that proposes the integration of academic theory and journalism training to help move journalism schools away from being industry-oriented to training students with a broader base knowledge about the world. Planning for a Curricular Change: A Report of the Project on the Future of Journalism and Mass Communications Education (Eugene, Oregon: School of Journalism University of Oregon, 1984) and Stuart Adam, “Thinking Journalism," Content, July/August 1988, pp. 4-11. 


\section{Appendix A: Interviewee List}

1. Terry A. Anderson. Former AP head of Middle East operations based in Beirut. Personal interview, Beirut, Lebanon. July 5, 2010

2. Hilary Appelman. Former AP correspondent in Jerusalem and former editor in New York. Email interview. Feb. 3, 2014

3. Donna Bryson. Former AP Middle East news editor based in Cairo. Email interview. Feb. 2, 2014

4. Noam Chomsky. Personal interview, Cambridge, MA. May 2009

5. Earleen Fisher. Former AP head of Middle East operations based in Cairo and former senior AP correspondent based in Beirut. Telephone interview. Oct. 25, 2013

6. Lauren Frayer. Former AP editor and journalist based in Cairo. Skype interview. March 31, 2014

7. Charles Glass. Former ABC News Middle East correspondent based in Beirut. Skype interview. Nov. 11, 2013

8. Charles J. Hanley. Retired AP Special Correspondent based in New York. Email interview. Sept. 14, 2013

9. Jacqueline Hazelton. Former AP editor in New York. Email interview. Feb. 26, 2014

10. Stephen K. Hindy. Former AP Middle East news editor in Beirut and Cairo. Telephone interviews, Nov. 13 and 182013

11. Ron Kampeas. Former AP editor in Jerusalem, New York and Washington. Email interview. Feb. 25, 2014

12. Ellen Knickmeyer. Former AP editor in New York. Email and Skype interviews. Jan. 27, Feb. 2, 2014

13. GG Labelle. Retired Middle East news editor based in Beirut, Jerusalem, Cairo; former senior editor in New York. Email interview. Sept. 12, 2013, March 4, 2014

14. Tim Llewellyn. Former BBC Middle East correspondent. Email interview. Dec. 5, 2014

15. Donald Mell. Former AP photographer based in Beirut. Telephone interviews. Feb. 11, 2013, Jan. 31, 2014

16. Alfred De Montesquiou. Former editor and correspondent based in Cairo. Skype interview. Feb. 28, 2014

17. Jasper Mortimer. Former AP editor based in Cairo. Email interview. March 23, 2014 
18. Elias Muhanna, Brown University professor. Email interview. Jul. 20, 2014

19. Anja Niedringhaus. The late AP photographer in Baghdad. Skype interview. Feb. 3, 2013

20. Ellen Nimmons. Assistant AP foreign editor. Telephone interview. Feb. 22, 2014

21. Greg Philo. Glasgow University professor. Skype interview. Oct. 24, 2013

22. Eileen Alt Powell. Retired AP correspondent in Beirut, Jerusalem and Cairo; retired editor in New York. Email interview. March 4, 2014

23. Dr. Amal Shamaa, pediatrician at Beirut's Berbir Hospital in 1982. Personal interview, Kuwait, February 2012

24. Susan Sevareid. Former AP editor in New York; former correspondent based in Cairo. Email interview. March 15, 2014

25. Leslie Shepherd. Former AP editor in New York. Personal interview, Toronto. Feb. 16,2014

26. Tanalee Smith, former AP editor in Cairo, New York and Asia. Email interview. April 26, 2013

27. Nicolas B. Tatro. Retired AP deputy foreign editor and former head of AP Middle East operations in Beirut and Jerusalem. Telephone interviews. August 2013.

28. Interviewee A, Email and Skype interviews. Jan. 27, Feb. 2, 2014

29. Interviewee B. Email interview. March 15, 2014

Interviewee C. Email interview. Feb. 15, 2014

30. Interviewee D. Email interview. Feb. 6, 2014

31. Interviewee E. Skype interview. Feb. 20, 2014

32. Interviewee F. Email interview. Feb. 17, 2014

33. Interviewee G. Telephone interview. Aug. 13, 2014

34. Interviewee H. Telephone interview. Oct. 25, 2013

35. Interviewee I. Skype interview. Feb. 28, 2014

36. Interviewee J. Skype interview. March 31, 2014

37. Interviewee K. Email interview. August 27, 2014 


\section{Appendix B: A History of The Associated Press ${ }^{1}$}

Based in New York City, The Associated Press is a multinational non-profit cooperative news agency owned by its contributing newspapers, radio and television stations in the United States. It has a photo service, two radio networks, a video news service, and a central role as a news source on the Internet's World Wide Web.

AP's origins were in international reporting, created by five daily newspapers in the United States to share the cost of transmitting news of the Mexican-American War by boat, horse express, and telegraph. David Hale of the Journal of Commerce proposed that the newspapers pool their resources to reproduce a single telegraphic report on each news event, one they could all publish - thus news became a salable commodity.

The newly invented rotary press, replacing flatbed printing, produced bigger, faster editions that led to the New York Tribune installing high-speed press in the 1870 s, allowing it to publish 18,000 papers per hour. In 1858 , news gathering took a big step across the Atlantic when the first transoceanic cable was laid in and the first news message from Europe arrived, addressed to The Associated Press, with 42 words summarizing five stories in headline: "MUTINY BEING QUELLED, ALL INDIA BECOMING TRANQUIL."

When hostilities broke out between the U.S. North and the South in 1861, the AP's chief executive, Daniel Craig, sent out platoons of reporters to learn on the job how to cover a war. Over time, on the move with Union armies, wiring in terse dispatches and writing them with reports sent by messenger, the AP journalists set a 
standard for the new specialty of combat correspondent - all under the anonymous byline "From The Associated Press Agent." During the American Civil War (18611865 ) and Spanish-American War of 1898 , there was a new incentive to write vivid, on-the-spot reporting leading to the Graphic Revolution and the ability to preserve and transmit images and print.

When Abraham Lincoln dedicated the cemetery at Gettysburg in November 1863, Joseph L. Gilbert, AP's 21-year old shorthand reporter, took down the president's words, checking them later against Lincoln's own text, and raced to the telegraph office at the Gettysburg depot where the report was sent to The Associated Press in New York. Weeks later, when Lincoln began preparing a final text of the address, he consulted the AP account to remind him of what he had said. For historians, that AP text became the most reliable account of one of American history's most memorable three minutes.

For decades stories had been written in a slow narrative style, such as the story that AP's congressional reporter Lawrence Gobright wrote. He began: "President Lincoln and wife, with other friends, this evening visited Ford's Theater..." Not until 200 words later, did the reader learn the president had been shot. At 30 to 40 words a minute, slow-moving copy often broke off before reaching the real news (telegraph wires strung through trees and over fences were notoriously unreliable). So in the 1880 s, AP editors began encouraging correspondents to write in a different style: the key facts first, in the "lead" 
paragraphs, followed by descending layers of detail. The "inverted pyramid" style championed by the AP became a hallmark of modern journalism.

In 1899, the AP was the first news organization to try out Guglielmo Marconi's new "wireless" device to transmit news. In 1914, it introduced the "telegraph typewriter" or teletypewriter, into newsrooms; the teleprinter transmitted directly to printers over telegraph wires. A worldwide network of 60 -word-per-minute teleprinter machine was built in the early 1970s. The AP was the first news agency to install a large-scale computer system for writing, editing and transmitting its reports. The teletype gave way to a "DataStream" that eventually ran 200 times faster.

In 1927, the AP inaugurated a photo service that distributed pictures by messenger and mail. In 1935, it launched the WirePhoto network, the world's first wire service for photographs that allowed transmission of news photographs over leased private telephone lines on the day they were taken. The first photograph to transfer over the network depicted an airplane crash in Morehouse, New York, on New Year's Day, 1935. Many of AP photographs have become world history icons: the famous images of the American flag being raised on Iwo Jima in 1945; Harry Truman beaming over his surprise election victory in 1948; the 1937 fiery crash of the Hindenburg. In 1980, the AP pioneered satellite transmission of news and in 1982 satellites began transmitting news photography. A photo of a solitary protester defying a line of tanks in Tiananmen Square in China in 1989 was one of many images that have immortalized some of the signature events of the past century. 
The news agency expanded from print to radio broadcast news in 1941 . In 1897, AP maintained just seven permanent bureaus outside the U.S. and Canada: Berlin, Havana, Honolulu, London, Mexico City, Tokyo, and Apia, Samoa. (It began dispatching reporters to major news events around the globe, including insurrections in Cuba in 1886, an international crisis in Samoa in 1889, the Philippines in 1899, and the Russian revolutions of 1905 and 1917.)

The cooperative grew rapidly under the leadership of Kent Cooper (served 1925-48), who built up bureau staff in South America, Europe, and after World War II, in the Middle East. Almost 200 reporters and photographers fanned out around the globe to cover World War II. The big European news agencies - "the cartel," as Cooper called them - had long frozen the AP out of the international news marketplace. But Reuters, the biggest, finally conceded a freer hand to the American agency in the mid-1930s, and the war's end left the AP in a strong position to sell its news in dozens of countries.

After Britain defeated German Field Marshal Erwin Rommel at the battle of El-Alamein in 1942, Cairo became the base for AP's Middle East war and postwar reporting. The news, however, was in neighboring Palestine, but the AP did not establish a full bureau there until 1967, just as the Arab-Israeli war erupted. Until then, Arab bureaus were not allowed to cover Israel, so coverage was handled from Istanbul. Cairo remained AP's regional headquarters for Middle East coverage from World War II until 1963, when Beirut, a financial crossroads, assumed that function. 
In the 1970s, AP plunged into the digital age. For journalists, Vietnam was a transitional war - the last before the digital revolution turned typewriters into museum curiosities and the first in which pictures and stories could be sent by satellite, though not from Vietnam itself. Television became a full-fledged war-reporting presence. Women made up about 10 percent of the press corps at any given time.

By 1975, Lebanon, AP's Middle East headquarters, had become hazardous duty with the outbreak of a protracted civil war between Palestinians and their leftist Lebanese allies, and right-wing Christians. By 1980, AP had cataloged more than 90 ad hoc fighting forces in Lebanon, including pro-Syrians, Christians, and Marxists, and Palestinians exiled from Jordan. "Beirut is a high-rise war with snipers and rocket crews controlling whole blocks of streets from 20-story buildings," said reporter Holger Jensen, recalling that reporters in Vietnam had had at least some measure of military protection. "Indiscriminate mortar fire comes from both sides. Teenage gunmen have a tendency to shoot anything that moves."

When the United States invaded the Caribbean island of Grenada in 1983 to overturn a Marxist military coup, military commanders barred the press, leading to an agreement by the Pentagon and news organizations for a system of "media pools" reporters ready to move on sudden notice with American forces in military operations. The wire services were guaranteed pool slots; other organizations rotated. The first combat test of the system came during the so-called tanker war in the Persian Gulf in 1987 and 1988. When American warships attacked Iranian naval vessels on April 18, 1988, after a U.S. frigate was severely damaged by an Iranian 
mine, an AP pool reporter filed a running eyewitness account directly from the bridge of another frigate to the Navy press office at the Pentagon. The operation was the most significant clash involving American surface warships since modern history's biggest naval battle at Leyte Gulf in 1944. Cutbacks at longtime U.S. rival United Press International, most significantly in 1993, left the AP as the primary nationally oriented news service based in the United States, although UPI still produces and distributes news stories and photos daily. Other English-language news services, such as Reuters and the English-language service of Agence France-Presse, are based outside the United States.

By the late 1980s, laptop computers, portable negative transmitters and satellite phones enabled reporters to dial out from most places to file on-the-spot copy and pictures. When U.S. Marines came ashore in the Somali capital Mogadishu in 1992, a city with no electricity and no telephones, an AP reporter was immediately able to file her story to the world. A 700-word story that once took 10 minutes to send takes just five seconds now.

In 1994, AP introduced APTV, a global news video service based in London, and AP All News Radio, a 24-hour audio format that allows even the smallest station to carry nonstop news. In photos, film-less digital cameras, developed with Kodak, coupled with digital darkrooms, enabled AP photojournalists to get pictures to papers in minutes - from shutter release to arrival in far-off newsrooms.

In 1996, AP Multimedia Services led the cooperative into the newest medium of all, the Internet. On the Web sites of many newspapers, an AP text-picture-sound 
link, dubbed "THE WIRE," became the gateway to continuously updated news of the U.S. and the world.

In 2004, the AP joined YouTube. In 2008, it launched AP Mobile (initially known as the AP Mobile News Network), a multimedia news portal that gives users news they can choose and provides anytime access to international, national and local news. AP was the first to debut a dedicated iPhone news application in June 2008, offering its own worldwide coverage of breaking news, sports, entertainment, politics and business, as well as content from more than 1,000 AP members and third-party sources. AP's multi-topic structure has lent itself to web portals, such as Yahoo! and MSN, all of which have news sites that constantly need to be updated. Often, such portals rely on the AP and other news services as their first source for news coverage of breaking news items. Yahoo!'s "Top News" page gives the AP top visibility out of any news outlet and the AP is also the news service used on the Wii's News Channel. Until the arrival of the internet, AP bureaus around the world were often the first stop for newly arrived journalists and for many resident correspondents. In times of crisis, it was AP's local staff who gave information and guidance on where to go and what to cover, as well as explain some of the complicated political environment of countries. 


\section{Endnotes}

1 The above information compiled from books published by the AP and AP links on the Internet about the
news organization: Alabiso, Vincent, Kelly Smith Tunney, Chuck Zoeller and Peter Arnett (2000) Flash!
The Associated Press Covers the World, Harry N. Abrams; The Associated Press, David Halberstam (2007)
Breaking News: How the Associated Press Has Covered War, Peace, and Everything Else, Princeton Archi-
tectural Press; The Associated Press, David Halberstam (2007) Breaking News: How the Associated Press
Has Covered War, Peace, and Everything Else, Princeton Architectural Press; and, https://www.facebook.-
com/pages/Associated-Press/109042952456316? group_id=0\# 
Appendix C: List of Internal AP Communications

1. Exchange of Internal AP private messages in May 2006 that I have kept in files between myself and Editor A in London about a story on mainstream Muslims of Europe's views on bombings in Europe.

2. Telephone conversation with leading French scholar of Islam, Olivier Roy, about Muslims of Europe.

3. Face-to-face conversation between myself and Editor A in London on the project about mainstream Muslims in Europe.

4. Conversation with AP stringer John Thorne in Morocco.

5. Internal AP private message from Editor B cautions me against making story sympathetic toward Hezbollah.

6. Verbal communication with Editor $\mathrm{C}$ in Beirut

7. Telephone conversation with deputy foreign editor, Editor D, in New York who quoted Editor $\mathrm{C}$ why he did not use the Baalbek story on the A-wire.

8. Verbal conversation with Editor E regarding story on Hezbollah being strong adversary to Israel.

9. Verbal conversation with Editor $\mathrm{F}$ in Beirut.

10. Editor G sent the proposed lead by AP message wire - seen in all Mideast bureaus - to the New York desk. I have a copy of the proposed lead, or as known in the AP, the "AMs line" or "Budget." It is not clear if the New York desk asked for revision of the lead. 
11. Editor G sent an email dated Sept. 5, 2009 to Beirut staff asking to change the way AP stories should address the casualty figures following a complaint from an unnamed person to AP headquarters.

12. Editor G forwards Sept. 5, 2009 email she sent to New York, referring to AP's failure "to note that facts about casualties" remain in dispute. The editor advised the staff to use alternative wording in adherence to the complainant's request.

13. Private message from me to Cairo bureau and one from Editor $\mathrm{H}$ to Jerusalem bureau to include Lebanese casualties in a brief story the latter had filed.

14. Editor I verbally relays verbal instruction from Editor $G$ to refrain from saying in stories that Israel destroyed Lebanon's infrastructure during the 2006 war.

15. Editor G in a December 2006 AP private message to Editor B asks to refrain from inserting the label "axis of evil" in my stories.

16. On June 3, 2010, Editor J told me in an excited voice about the toddler wearing an mock suicide belt, to which I said, "And you made sure photos took pictures of him;" to which he replied: "of course." 


\section{Appendix D: Letter from Tel Aviv Bureau Chief Frank Crepeau to Sr. Editors}

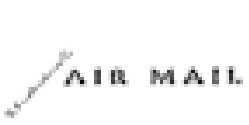

\author{
$C \mathrm{CC}: 5 \%$ \\ THE ASSOCIATED PRESS \\ p, o, nox aosวo
}

TRL AVIV Stsoo. ISHAEL.

Hr. Doolling

Heoein

$$
\text { Doax utto, }
$$

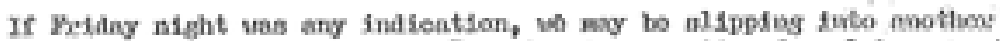

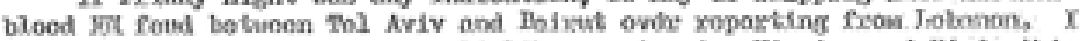

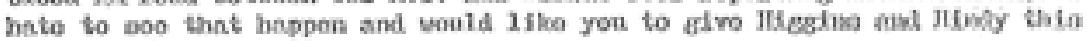
lottox to oxplain owe zesis point of viou.

that Tel. Aviv wan trying to to usn back wp lesixut on a dicrtomit and

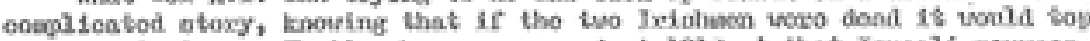

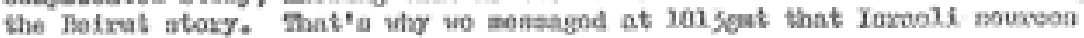
vexe anying thay voxe dend.

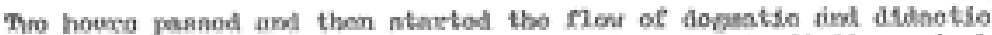

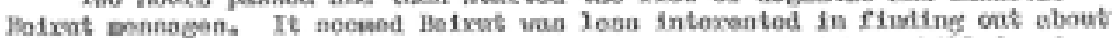

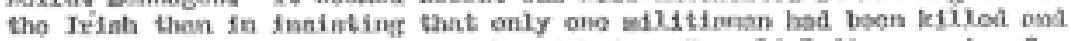
indfenting that Tol Aviv had nimply pieknd up Imsold Radio xoportis of npurioun Hadded elasene.

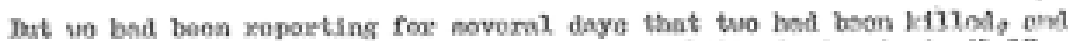

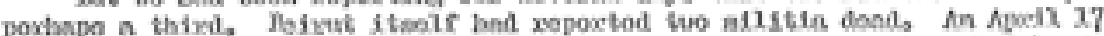
UxuPJ, bullotin ly Caknol had roparted it. Donponniblo ropextess hat bocis

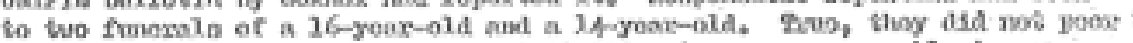

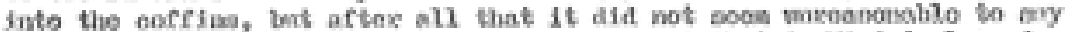

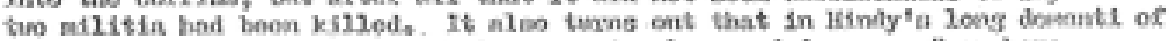

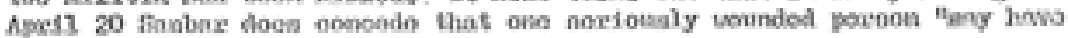
Afäd Intext"

The elarihen in nowthexn Johanon axo not no woll plamod that vo mos tiblo

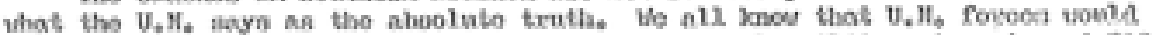

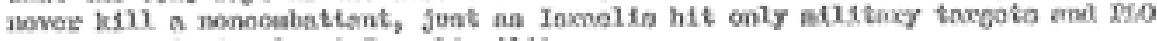
zosde axe aised only at Inxools nilitaxy.

Tho aimple, blsok and thit vornion in that Inxtolf-babood silitin

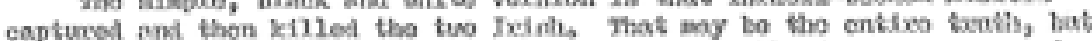
thoxa in another vornion involvinis a blood foul, oalls ros venpeanoo ond

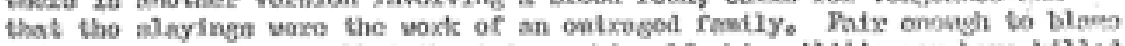

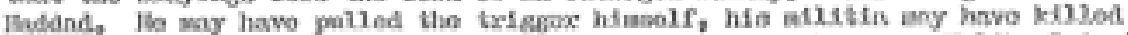

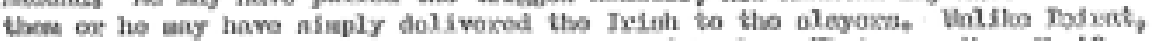

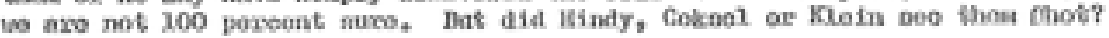

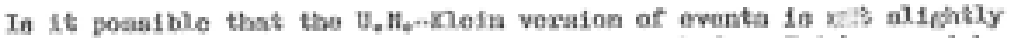

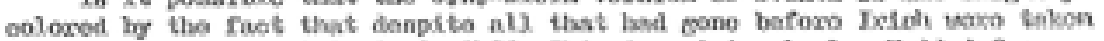

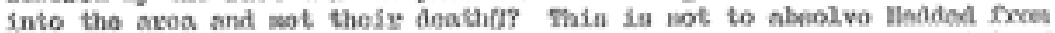

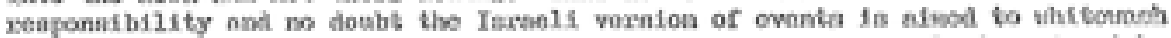
lleddal if at all posaible, Tho point 30 , wo txy to aneese, ovatuato and voled noureen thother thoy axo tho U.N.. Iaraelif milstaxy, Hadilnd, "un the apot gunxeilla coursndorn," xestidents of forafand ox the RLO, 


\section{Át MAIL}

t

\section{THE ASSOCIATED PRESS}

7. 0.

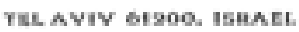

2.

In hin dinquiation MSl9 of speil 20 an allitia, Ifindy nidit toll brov

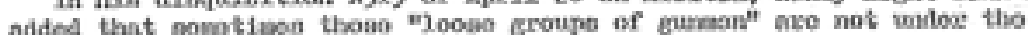

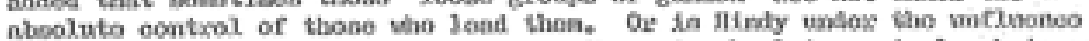

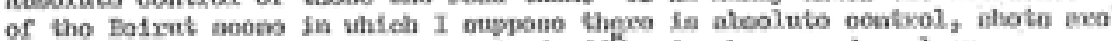
fixod only on the npooific conwand of offiore in ehargo and a cloonc, funetionfing ohsin of equeand extets?

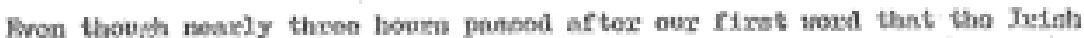
wowo doad, Tol Aviv did not firo off monisagoe to laixut asi Ifr noctuing

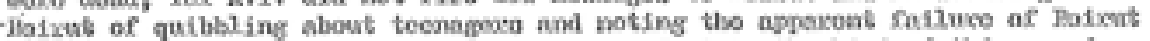

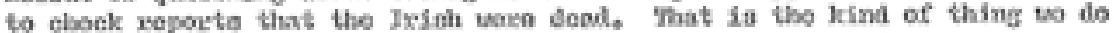
not do and do not appreesinto other bosoann of neenning un of,

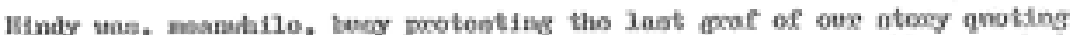

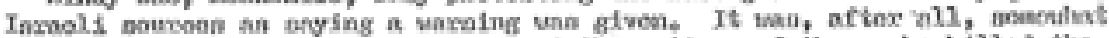
hoside the pofut and in no why oxewood the notiens of thoeo who fillod tho

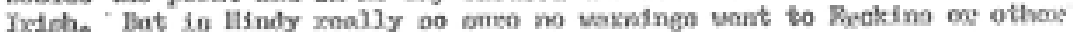

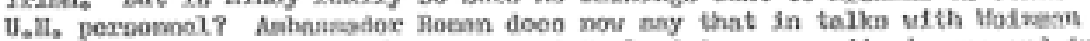

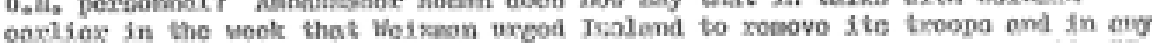

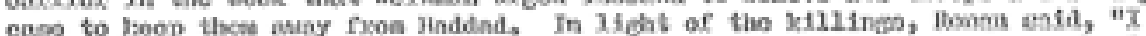

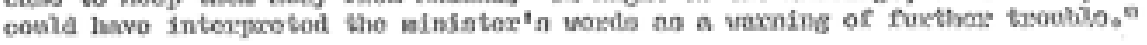

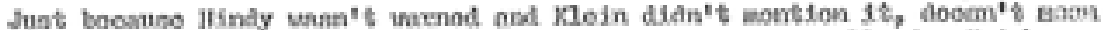

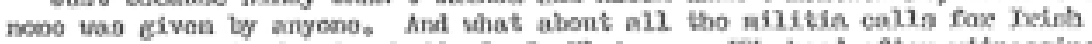
blood and dononds for tuo bodion? So Xloin boed JEX ahood oftox vitunoesing

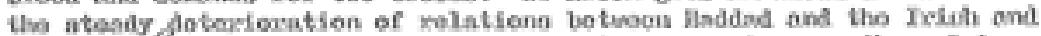

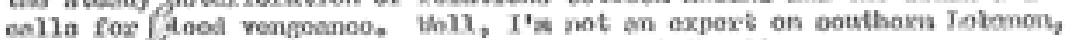
unt"I voukan't havo thoudit it a cood idea at the timo.

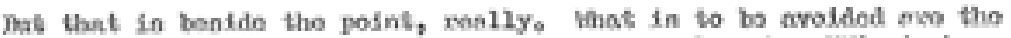

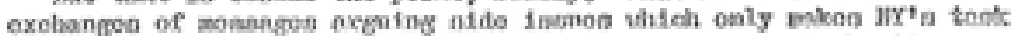

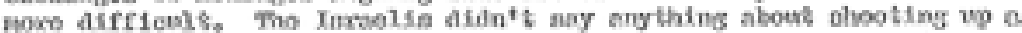

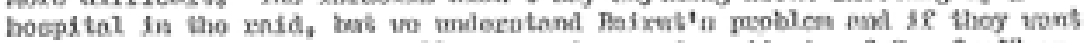

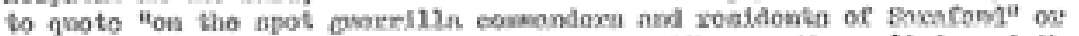

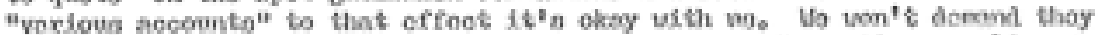

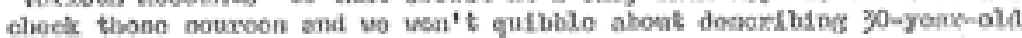

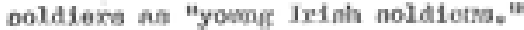

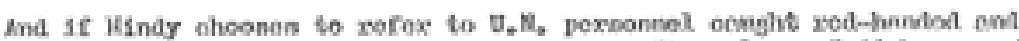

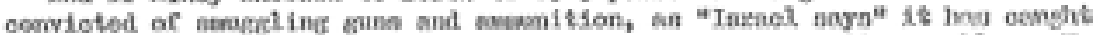

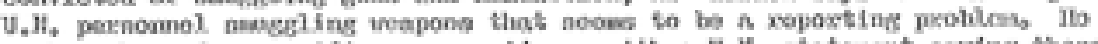

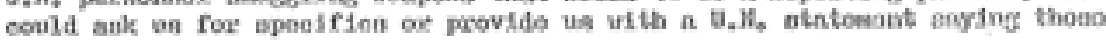
poruons waxo bowohon fresed ant ratlwoadod,

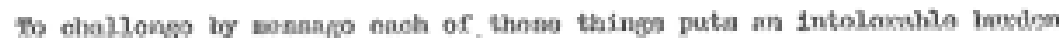

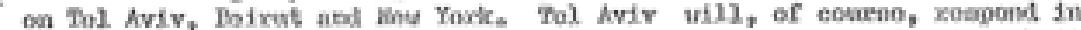

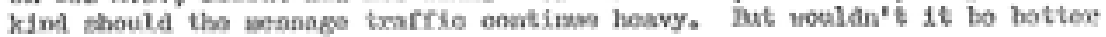
if we could work tognther?

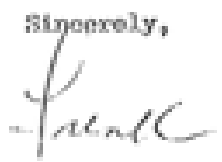




\section{Appendix E: Letter from Beirut News Editor Stephen Hindi to Senior Editors}

1.Assc

shoot

$\underline{\text { nid }=1}$

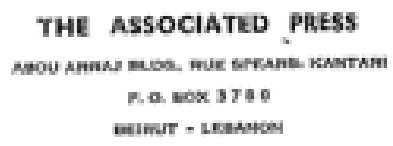

Juno 2. 1980

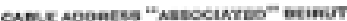

The nob newas - asees * mats

Telex aptsi is

2. Assi He. Polotrotilicy Mew Yoxk

push $€$

Dear Wate,

$\underline{\text { Repo }}$

$I$ wis angered to see from U.S. press oxppings of my April 18 rirst-

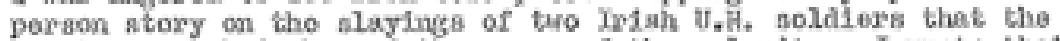

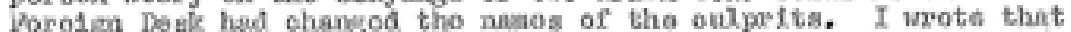

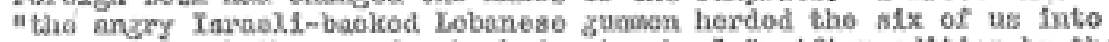
$\mathrm{a}$ downsteivs bathroch of a boubod"out sohool." after editing by the

3.The porelen Dosk, the stiory anid "tho angry fobenose gununo..."

4. Mar

$x$ do not dispute the authorsty of the Dosk in madcing nows fudgatont, but on a rixst-pexson ploco, y. thint it is imperativo that the roporter bo eonsultod when key obsuges aro belng made.

1982.

Had the doak anked mo to justify what I urs beying in the load, I Bdadiy would have dono so. Wa . Klein snd Cegt. Vineont, the two U.ll. obseru vers in the group, xooognisod at least one nowber of the group thint

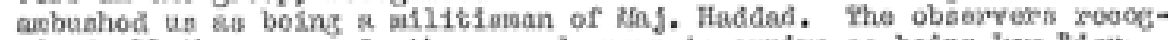
ndrod al, the grumen in the socond group to arrive as bolng key Rteu-

Nicola tenonte of Haddra. Kotn and Vinoent lonew then by nawe.

"Syria

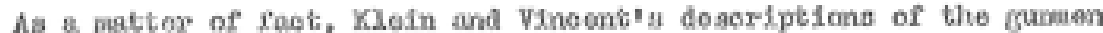
wore mosanged to Nou York when Iorael. noizes atarted putting out their vorelon of the story (Arab vilisgera...). Fo the oxedit of the Desk, those dosoxiptions nppesired sin some of the olipplnge, $Y$ have re*

$\underline{\text { article: }}$ oeived. But ang riret-parson plece was not oorreoted.

\section{Bar1 wotns, oto. 'By dolng this, wo ensaxe the baelcers shmes sone of the xosponsibility for the deeds of thoir olienter. The Iaradis aupply

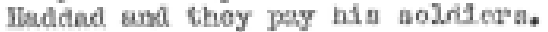

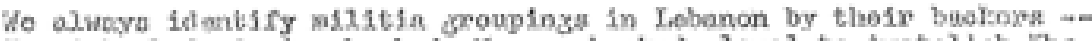

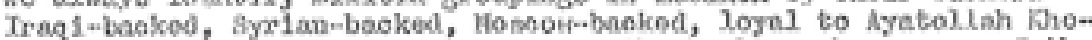

In $\mathrm{Co} \quad$ way not Inraoli-beciced, nud why wasn't $I$ conandted?

6. Mic

7. Farc

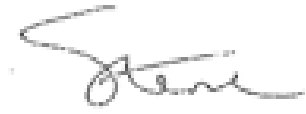

8. AP؛

Israel

Steplen K. Hindy

News EAlar - Middlo Esit Stricen

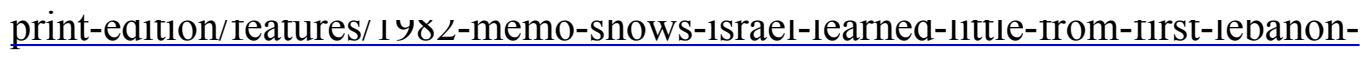

war-1.279802 
9. George Gedda, AP archives, July 30, 1982.

10. Arthur Max, AP archives, "Israel Angry with War Critics,” Aug. 7, 1982.

11. Charles J. Hanley, AP archives, “Lebanon Crisis Won't End With PLO Pullout,” Aug. $14,1982$.

12. AP published in New York Times, PLO Troops Begin Pullout in Beirut, Aug. 22, 1982. http://www.nytimes.com/1982/08/22/world/plo-troops-begin-pullout-in-beirutfrench-enter-city.html

13. The Associated Press, archives, Sept. 10, 1982.

14. Marcus Eliason, AP archives, "Gemayel Death Could Be Third Israeli Setback in Lebanon," Sept. 15, 1982.

15. David Minthorn, AP archives, "Brezhnev Blames U.S. for Massacre, Urges U.N. Action, Sept. 20, 1982.

16. Larry Thorson, AP archives, "Defense minister with big ideas for Israel," Sept. 22, 1982.

17. Marcus Eliason, AP archives, Sept. 25, 1982.

18. AP archives, “Colonel Who Resigned Over War Speaks for First Time,” Sept. 1982.

19. Scheherezade Faramarzi, AP published in Philadelphia Inquirer, "Survivors: Israelis Watched Massacre,” Dec. 22, 1982.

20.Scheherezade Faramarzi, The Galveston Daily News, "Exporting Islamic fundamentalism to Lebanon, Nov. 6, 1982. http://www.newspapers.com/newspage/16609382/

21. Scheherezade Faramarzi, AP published in The Gettysburg Times, "Victims tell of terror shelling by battleship New Jersey," Feb. 14, 1984. 
22. Scheherezade Faramarzi, AP published in Tulsa World, "Cycle of Resentment Grows in Israeli-occupied Lebanon,” May 13, 1984.

23. AP archives, "EDITOR'S NOTE - THE FOLLOWING COPY WAS SUBMITTED TO THE ISRAELI,” June 16,1985. TEL AVIV EDITOR'S NOTE - The following copy was submitted to the Israeli military censor, who ordered a significant deletions. http:// www.apnewsarchive.com/1985/EDITOR-S-NOTE-The-following-copy-was-submitted$\underline{\text { to-the-Israeli-military-censor-who-ordered-a-significant-deletions-/id-304c } 7 \mathrm{c} 3 \mathrm{eb} 2 \mathrm{e} 6 \mathrm{fb}-}$ $\underline{\mathrm{ca} 03 \mathrm{~d} 6 \mathrm{cb} 3 \mathrm{e} 49 \mathrm{ec} 6731}$

24. Edmond Shedid, AP archives, "Seven Wounded in Israel Copter Raid, 2 Killed in Tank Fire,” May. 4, 1993. http://www.apnewsarchive.com/1993/Seven-Wounded-In-Israeli-Copter-Raid-2-Killed-in-Tank-Fire/id-9b04ea2f7477bba5af8fe20fd04207be 25. AP archives, "Guerrillas Fire Katyusha Rockets on Norther Israel," April 9, 1996. 26. Israelis Again Fire on Rebel Hub in Beirut, April 12, 1996. http://www.deseretnews.com/article/483092/ISRAELIS-AGAIN-FIRE-ON-REBEL-HUB-IN-BEIRUT.html? $\mathrm{pg}=\mathrm{all}$

27. Barry Schweid, AP archives, Christopher Works on Agreement to Halt Israel-Hezbollah Conflict, April 15, 1996. http://www.apnewsarchive.com/1996/Christopher-Workson-Agreement-to-Halt-Israel-Hezbollah-Conflict/idd5ee2ce426cb3e7b1103ce545c5e01d8?SearchText=lebanon\%20April \%201996\%20hezbollah\%20israel\%20;Display 
28. Hussein Dakroub, The Brownsville Herald, "Israel-Hezbollah battles claim more lives in Lebanon,” April 16, 1996. http://newspaperarchive.com/us texas/brownsville/ brownsville-herald/1996/04-16/page-3

29. Jack Katzenell, AP archives, "Overwhelming public support for bombardment of Lebanon," April 16, 1996. http://newspaperarchive.com/us/texas/brownsville/ brownsville-herald/1996/04-16/page-3

30. Dianna Cahn, AP archives, "Israelis Flee Rocket Fire, But Strongly Support War, April 16, 1996.

31. Nicolas B. Tatro, AP archives, "U.S. Truce Proposals: International Monitoring and Syrian Guarantee, April 17, 1996. http://www.apnewsarchive.com/1996/U-S-Truce-Proposals-International-Monitoring-And-Syrian-Guarantee/id-ecf4922d8d05458c41da4e6c2a8e3ade?SearchText=lebanon\%20April\%201996\%20hezbollah\%20israel $\underline{\% 20 ; \text { Display }}$

32. Scheherezade Faramarzi, AP, “Israeli Arabs: Government doesn't protect us from rockets." April 17, 1996, http://www.apnewsarchive.com/1996/Israeli-Arabs-Government-Doesn-t-Protect-Us-from-Rockets/id-0c8ba8001532115d3049f10e087f8e3f? $\underline{\text { SearchText }=\text { Scheherezade } \% 20 \text { faramarzi } \% 201996 \% 20 \text { Arab\%20Israelis\%20shelters }}$ $\underline{\% 20 ; \text { Display }}$

33. Robert H. Reid, AP archives, Pressure Mounts in Security Council for Cease-fire in Lebanon, April 18, 1996.

34. Tarek al-Issawi, AP archives, "Israeli Aircraft Attack Apartment Building in Southern Lebanon, 11 Killed," April 18, 1996, http://www.apnewsarchive.com/1996/Israeli-Air- 
craft-Attack-Apartment-Building-in-Southern-Lebanon-11-Killed/

id-0af1bc2f474a8cd46a22dc5f803551d5

35. AP published in Arizona Daily Wildcat, "Israeli attack kills 75 UN refugees," April

19, 1996. http://wc.arizona.edu/papers/89/141/01_2_m.html

36. AP archives, "Chronology of Recent Fighting," April 19, 1996. http://www.ap-

newsarchive.com/1996/Chronology-of-Recent-Fighting/id-7608f3ed94a7e12a-

ca9de9e540bddcba?SearchText=lebanon\%20April\%201996\%20hezbollah\%20israel

$\underline{\% 20 ; \text { Display }}$

37. Dafna Linzer, News Press, April 21, 1996. http://archives.savannahnow.com/

sav_pdf_archive/text/ fr147/A_2323472.pdf

38. Sam F. Ghattas, AP archives, "Christopher in Lebanon, Israeli Warplanes, Gunboats

in Action,” April 24, 1996. http://www.apnewsarchive.com/1996/Christopher-In-

Lebanon-Israeli-Warplanes-Gunboats-In-Action/id-

ac712413140aa0068461a6312b7a5c05?SearchText=lebanon\%20April

\%201996\%20hezbollah\%20israel\%20;Display_

39. Hilary Appelman, AP archives, "Israelis Say Fighting to Prevent New Tragedy," April $25,1996$.

40. Louis Meixler, AP archives, "UN General Assembly Condemns Israeli Attack on Civilians in Lebanon," April 26, 1996. http://www.apnewsarchive.com/1996/U-N-General-Assembly-Condemns-Israeli-Attack-on-Civilians-in-Lebanon/idef6ad8298d968f103c7ce9727f26198a?SearchText=lebanon\%20April \%201996\%20hezbollah\%20israel\%20;Display_ 
41. Tarek Al-Issawi, South Coast Today, “Lebanese refugees go home.” Saturday April 28, 1996. http://www.southcoasttoday.com/apps/pbcs.dll/article?AID=/19960428/

\section{$\underline{\text { NEWS/304289998 }}$}

42. Robert H. Reid, AP archives, "Israel's Artillery Commander Denies UN Camp was Targeted," May 6, 1996. http://www.apnewsarchive.com/1996/Israel-s-Artillery-Commander-Denies-U-N-Camp-Was-Targeted/id-b31cdd71ba2242d2a6dd1d903f864bf3

43. AP published in Los Angeles Times, "Videotape Supports Claims Israel Targeted UN Base,” May 7, 1996. http://articles.latimes.com/1996-05-07/news/mn-1404_1_u-n-base

44. Nicolas B. Tatro, AP archives, "Peres Says UN Report One-sided, Israel Releases Own Video,” May 8, 1996. http://www.apnewsarchive.com/1996/Peres-Says-U-N-Report-One-Sided-Israel-Releases-Own-Video/id-093623e23748028d9a3fa8d88e3d0fc1? SearchText=lebanon\%20April\%201996\%20hezbollah\%20israel\%20;Display 45. Nicolas B. Tatro, AP archives, "Israel Blames Peacekeepers for Contributing to Qana Shelling Tragedy," May 15, 1996. http://www.apnewsarchive.com/1996/Israel-BlamesPeacekeepers-For-Contributing-To-Qana-Shelling-Tragedy/id-6e66bec43ff9d55ffc84718eaba3061d?SearchText=lebanon\%20April\%201996\%20hezbollah\%20israel $\underline{\% 20 ; \text { Display }}$

46. Scheherezade Faramarzi, AP archives, "Rabbis and Sheiks," June 10, 1996. 47. Ahmed Mantash, AP published in South Coast Today, "Guerrillas gloat over slain Israelis," Sept. 6, 1997. http://www.southcoasttoday.com/apps/pbcs.dll/article?AID=/ 19970906/NEWS/309069921\&emailAFriend $=1$ 
48. George Jahn, Associated Press archives, “Officials: Tubing may have Iraq link,” Sep. 18, 2002. http://www.apnewsarchive.com/2002/Officials-Tubing-May-Have-Iraq-Link/ id-77ece27e01da699ca7ea4db69245d5de? SearchText=george\%20jahn\%20Iraq\%20alu$\underline{\text { minum } \% 20 \text { tubes } \% 202002 ; \text { Display }}$

49. Scheherezade Faramarzi, AP published on Jacksonville.com, "Jittery U.S. soldiers firing in the dark kill six Iraqis trying to get home before curfew," August 10, 2003.http://jacksonville.com/tu-online/apnews/stories/081003/D7SR8BVG5.html 50. Scheherezade Faramarzi, AP published on $C B S$ Website, "Palestinians' Rage At U.S. Festers ," April 23, 2004 - http://www.cbsnews.com/news/palestinians-rage-at-us-fes$\underline{\text { ters/ }}$

51. Scheherezade Faramarzi, Associated Press, May 20, 2004, “U.S. Aircraft Reportedly Kills 40 Iraqis" -http://www.fpp.co.uk/online/04/05/Iraq_wedding_massacre.html 52. Scheherezade Faramarzi, Associated Press, May 21, 2004,’'Iraqi survivors recount US tent shelling after wedding party"- http://www.boston.com/news/world/middleeast/articles/2004/05/21/iraqi_survivors_recount_us_tent_shelling_after_wedding_party/ 53. Anthony Deutsch, AP published in Spartanburg Herald-Journal, "No wedding at border, says military: Evidence: Military binoculars, guns and passports,” May 23, 2004. http://news.google.com/newspapers?

$\underline{\text { nid }=1876 \& \text { dat }=20040523 \& i d=z z 0 f A A A A I B A J \& s j i d=Z N A E A A A A I B A J \& p g}=6847,32$ $\underline{33021}$

54. Scheherezade Faramarzi, May 24, 2004, "Video Contradicts US Military, Shows Iraq Wedding Celebration" - http://www.commondreams.org/headlines04/0524-02.htm 
55. Scheherezade Faramarzi, May 25, 2004, "Photos may show U.S. attacked safe house, not wedding" - http://airwolf.lmtonline.com/news/archive/052504/pagea8.pdf

56. Joseph Panossian, AP published in Desert News, "Hezbollah captures 2 Israeli soldiers in clashes, sparking Israeli offensive into Lebanon,” July 12, 2006. http://www.de$\underline{\text { seretnews.com/article/640194197/Hezbollah-captures-2-Israeli-soldiers-in-clashes- }}$ sparking-Israeli-offensive-into-Lebanon.html?pg=all

57. Steven Gutkin, AP published in NBC News, "Crisis allows Israel to pursue strategic goals, July 13, 2006. http://www.nbcnews.com/id/13847803/ns/world_news-mideast$\underline{\mathrm{n} \_ \text {africa/t/crisis-allows-israel-pursue-strategic-goals/\#.U8rpioBdUUd. }}$.

58. Ravi Nessman, AP published in Southeast Missourian, "Israeli troops raid Lebanon," Jul 13, 2006. http://www.semissourian.com/story/1160085.html 59. AP published AP published in on Fox News "Israel: No Targets in Lebanon Are Immune,” July 13, 2006, http://www.foxnews.com/printer_friendly_wires/ $\underline{\text { 2006Jul13/0,4675,IsraelLebanonMilitary,00.html }}$

60. Steven Gutkin, AP published in Washington Post, "Israel PM's Bid to Free 3 Soldiers a Gamble," July 14, 2006. http://www.washingtonpost.com/wp-dyn/content/article/ $\underline{2006 / 07 / 14 / A R 2006071401348 ~ p f . h t m l ~}$

61. Sam F. Ghattas, AP published in on Katu.com. "Israel continues to punish Lebanon, hits fuel supply,” Jul 14, 2006. http://www.katu.com/news/3632791.htm 62. Hamza Hendawi and Lee Keath, AP story published in Freedom Republic, "Israel sends ground forces into Lebanon," July 17, 2006. http://www.freerepublic.com/focus/f$\underline{\text { news } / 1667025 / \text { posts }}$ 
63. AP published in military.com, "Israel Answers Attacks," July 17, 2006. http://www.military.com/NewsContent/0,13319,105739,00.html?ESRC=eb.nl

64. AP published on Fox News, "Hezbollah Rocket Attack Kills Two in Nazareth," July 19, 2006.

65. Donna Abu Nasr, AP published in Washington Post, "Famed Beirut nightlife shows resilience," July 22, 2006. http://www.washingtonpost.com/wp-dyn/content/article/ 2006/07/22/AR2006072200543 pf.html

66. AP archives, "Israel-Wrong Nasrallah,” Jul 22, 2006.

67. Associated Press, AP published in USA Today, "Battles continue; Israel warns people to leave south Lebanon," Jul 21, 2006. http://usatoday30.usatoday.com/news/world/ 2006-07-20-israel-lebanon_x.htm

68. Sally Buzbee, AP published in Desert News, "News analysis: Fighting could tip balance toward extremists," July 23, 2006. http://www.deseretnews.com/article/640196964/ Fighting-could-tip-balance-toward-extremists.html?pg=all

69. Charles J. Hanley, AP published in Washington Post, "2 Key Americans See 1982 in Lebanon '06," July 23, 2006. http://www.washingtonpost.com/wp-dyn/content/article/ 2006/07/23/AR2006072300210.html

70. Scheherezade Faramarzi, AP published in Washington Post, "Hezbollah Says Israeli Response a Surprise," July 25, 2006. http://www.washingtonpost.com/wp-dyn/content/ article/2006/07/25/AR2006072500974.html

71. Ravi Nessman, AP archives, “Mideast Fighting,” Jul 28, 2006.

72. Hamza Hendawi, AP, “Israel Targeting Hezbollah Infrastructure,” Jul 26, 2006. 
73. Ravi Nessman, AP published in Free Republic, "Israel OKs call-up of 30,000 reservists, Jul 27, 2006. http://www.freerepublic.com/focus/f-news/1673413/posts

74. Sally Buzbee, AP published in USA Today, "In guerrilla war, Hezbollah may have an edge, Jul 30, 2006. http://30.usatoday.com/news/world/2006-07-30-hezbollah-analy$\underline{\text { sis X.htm }}$

75. Matti Friedman, AP published in Washington Post, "Plumbers Come to Rescue in Israeli Shelter," July 31, 2006;. http://www.washingtonpost.com/wp-dyn/content/article/ 2006/07/27/AR2006072701046 pf.html

76. Aron Heller, AP published in Washington Post, "Northern Israelis Adapt to Life Under Fire,” July 31, 2006. http://www.washingtonpost.com/wp-dyn/content/article/ 2006/07/31/AR2006073100540.html

77. Hussein Dakroub, AP archives, "Israel sends armored troops into Lebanon," Aug. 1, 2006.

78. Scheherezade Faramarzi, AP published in Washington Post, "Hezbollah's Fight Impresses Supporters," August 2, 2006. http://www.washingtonpost.com/wp-dyn/content/ article/2006/08/02/AR2006080200362_pf.html

79. Scheherezade Faramarzi, AP archives, "Night of Death,” Aug. 3, 2006.

80. AP published on Fox News, "Israeli Forces Battle Hezbollah in Tyre, Launch Multiple Airstrikes Across Country, Aug. 5, 2006. http://www.foxnews.com/story/2006/08/05/ israeli-forces-battle-hezbollah-in-tyre-launch-multiple-airstrikes-across/ 
81. Aron Heller, AP published in Irish Examiner, "Israel suffers deadliest attack as rockets kill 15," August 7, 2006. http://www.irishexaminer.com/world/israel-suffers-deadliest-attack-as-rockets-kill-15-10244.html

82. Anne Gearan, AP published in South Coast Today, "Deal to end fighting won't help U.S. image," Aug. 13, 2006. http://www.southcoasttoday.com/apps/pbcs.dll/article? $\underline{\mathrm{AID}=/ 20060813 / \mathrm{NEWS} / 308139977 \& \mathrm{cid}=\text { sitesearch }}$ 83. Kathy Gannon, AP published in the Washington Post, "Lebanese Find Destruction Back Home,” Aug. 14, 2004. http://www.washingtonpost.com/wp-dyn/content/article/ 2006/08/14/AR2006081400821_pf.html

84. Steven Gutkin, AP published in Washington Post, "When Will Be Next Mideast War?” Aug 14, 2006. http://www.washingtonpost.com/wp-dyn/content/article/ 2006/08/14/AR2006081400721.html 85. AP published in Washington Post, "Mideast War, by the Numbers," Aug. 17, 2006. http://www.washingtonpost.com/wp-dyn/content/article/2006/08/17/ $\underline{\text { AR2006081700909 pf.html }}$ 86. Scheherezade Faramarzi, AP published in Roth Army, "Hezbollah puts down deep roots," Aug. 21, 2006. http://www.rotharmy.com/forums/archive/index.php?t-39537.html 87. Todd Pitman, AP published in Washington Post, "Lebanese Father Mourns Loss of Family,” Aug. 29, 2006. http://www.apnewsarchive.com/2006/Lebanese-Father-MournsLoss-of-Family/id-e1d3f2e7ca6b594bc91988310e5d4f65?SearchText=\%20marwaheen \%202006; Display 
88. AP published on Fox News, "Haifa Man Dies From Lebanon War Wounds," Aug. 31, 2007. http://www.foxnews.com/printer friendly wires/2007Aug31/0,4675,BRFIsraelWarFatality,00.html

89. AP, "Saving animals through 40 days \& nights of war in Lebanon \& Israel, September 2006. http://www.animalpeoplenews.org/06/09/tsg.savinganimals09.06.htm.

90. Hamza Hendawi, AP, Nasrallah's Popularity Climbs, Sept. 25, 2006. http://www.apnewsarchive.com/2006/Nasrallah-s-Popularity-Climbs/id$\underline{\text { da048352fd04c1028ed08a9a34ffb1db }}$

91. Hamza Hendawi, AP published in Washington Post, "U.N.-Israel Encounter Highlights Discord," Sept. 29, 2006. http://www.washingtonpost.com/wp-dyn/content/article/ 2006/09/29/AR2006092900986_pf.html

92. Scheherezade Faramarzi, AP on Highbeam Business, "Iran stands as a power in Mideast,” Dec. 10, 2006. http://business.highbeam.com/435553/article-1G1-155721246/ iran-stands-power-mideast

93. Sam F. Ghattas, AP archives, "Lebanon Sees More Than 1,ooo War Deaths, Dec. 28, 2006.

94. Jim Krane, AP, March 24, 2007, AP published in The St. Augustine Record, "Iranian forces seize 15 U.K. sailors, marines,"

95. AP published on Fox News, "Haifa Man Dies From Lebanon War Wounds," Aug. 31, 2007. http://www.foxnews.com/printer_friendly_wires/2007Aug31/0,4675,BRFIsraelWarFatality,00.html 
96. Kim Gamel, AP published in USA Today, Feb. 28, 2008, "US mil: Iraqi killed north of Baghdad" - http://usatoday30.usatoday.com/news/world/2008-02-28-1394763717_x.htm 97. George Jahn, “AP EXCLUSIVE: GRAPH SUGGESTS IRAN WORKING ON BOMB," Nov. 27, 2012. http://bigstory.ap.org/article/ap-exclusive-graph-suggests-iran$\underline{\text { working-bomb }}$

98. Associated Press, "Social Media Guidelines for AP Employees," May 2013. http:// www.ap.org/Images/Social-Media-Guidelines_tcm28-9832.pdf

99. https://www.facebook.com/pages/Associated-Press/109042952456316?group_id=0\# 


\section{Appendix F: Some of the General Questions Posed to AP Interviewees}

1. Describe the changes that have taken place over the years in AP coverage of Middle East conflicts. Give details with examples and areas these changes were most felt.

2. What was the process - in detail with specific examples - of AP news gathering, writing, editing and final publication? What factors influenced news selection, finding news sources? What were most of the reporting and writing of the news dependent on?

6. Were AP journalists, especially senior editors, under pressure to report certain stories from higher ups in the organization, from government, the US military, or lobbyists? If yes, how much did these pressures influence AP coverage? Did the AP resist such pressures in any way? Please provide examples.

7. Was the AP - among other news organizations - uncritical of President Bush's campaign for war against Iraq? What exactly happened in the discussion meetings on the subject?

8. Did the AP, like other news organizations, demonstrate patriotism in post-9/11 coverage? If yes, was there a specific policy to do so? Any specifics/examples?

9. Are there any suggestions as to how to strengthen practices for the reporting on the Middle East that is independent and accurate? 


\section{References}

Albasio, Vincent, Kelly Smith Tunney, Chuck Zoeller and Peter Arnett,, Flash! The Associated Press Covers the World, Harry N. Abrams 2000.

Anderson, Terry A, Den of Lions: Memoirs of Seven Years (New York: Random House, 1993).

Bergen, Peter L, The Osama Bin Laden I Know: An Oral History of Al Qaeda's Leader (New York: Free Press, 2006).

Carpentier, Nico, The ideological model of war: Discursive mediations of the Self and the Enemy, (Amsterdam/New York: Rodopi, 2011).

Chomsky, Noam, Fateful Triangle: Israel, the United States, and the Palestinians (Montreal: Black Rose Books Ltd., 1984).

Cottle, Simon, Mediatized Conflict: Development in Media and Conflict Studies. (UK: Open University Press, 2006).

Farquhar, Scott C. (Lieutenant-Colonel), Back to Basics: A Study of the Second Lebanon War and Operation Cast Lead, (Defense Department, 2009).

Fisk, Robert, Pity the Nation: The Abduction of Lebanon. (UK: Andre Deutsch, 1990).

Friedman, Thomas L. From Beirut to Jerusalem (London: Collins, 1990).

Gans, Herbert J, Deciding What's News: A Study of CBS Evening News, NBC Nightly News, Newsweek, and Time, (Chicago: Northwestern University Press, 1979).

Gilmour, David, Lebanon: The Fractured Country (UK: Sphere Books, 1984).

Hallin, Daniel C. The "Uncensored War": The Media and Vietnam (California: University of California Press, 1989).

Herman, Edward S and Noam Chomsky, Manufacturing Consent: The Political Economy of the Mass Media, (New York: Pantheon, 2002).

Hirst, David, Beware of Small States: Lebanon, Battleground of the Middle East, (Nation Books, 2011).

Karim, Karim H. Islamic Peril: Media and Global Violence (Montreal: Black Rose Books, 2002). 
Kapeliouk, Amnon, Sabra \& Shatilla: Inquiry into a Massacre, translated from French by Khalil Jahshan (Belmont, MA: Association of Arab-American University Graduates, 1984).

Knightly, Philip, The First Casualty: The War Correspondent as Hero and Myth-Maker from the Crimea to Iraq (Maryland: Johns Hopkins University Press, 2004).

Said Makdisi, Jean, Beirut Fragments: A War Memoir (New York: Persea Books, 1990).

McChesney, Robert, Rich Media, Poor Democracy: Communication Politics in Dubious Times (New York: The New Press, 1999).

McLuhan, Marshall and David Carson The Book of Probes (NY: Ginko Press, 2003).

Mearsheimer, John J and Stephen M. Walt, The Israel Lobby and U.S. Foreign Policy (New York: Farrar, Strauss and Giroux, 2007).

Morris, Benny, The Righteous Victims: A History of the Zionist-Arab Conflict, 1881-1999 (New York: A. Knopf, 1999).

Norton, Augustus Richard, Hezbollah: A Short History (New Jersey: Princeton University Press, 2007).

Petran, Tabitha, The Struggle Over Lebanon (New York: Monthly Review Press, 1987).

Philo, Greg and M. Berry, Bad News from Israel (London: Pluto, 2004).

Said, Edward, Covering Islam: How the Media and the Experts Determine How We See the Rest of the World (New York: Knopf Doubleday Publishing Group, 1997).

Schiff, Ze'ev and Ehud Ya'ari, Israel's Lebanon War (New York: Simon and Schuster, 1984). Ariel Sharon, Warrior: An Autobiography (New York: Simon and Schuster, 1989).

The Associated Press, Breaking News: How the Associated Press Has Covered War, Peace, and Everything Else (New York: Princeton Architectural Press, 2007).

Tumber, Howard and Frank Webster, Journalists under Fire: Information War and Journalistic Practices (New York: Sage Publications, 2006).

Vallone, Robert P, Lee Ross, and Mark R. Lepper, "The Hostile Media Phenomenon: Biased Perception and Perceptions of Media Bias in Coverage of the Beirut Massacre," Journal of Personality and Social Psychology (California: Stanford University, 1985). 
References

Zelizer, Barbie and Stuart Allan, Journalism After September 11 (New York: Routledge, 2001). 


\section{List of Cited AP Stories}

1.Associated Press published in Spokane Chronicle, "Israel bombs Beirut to avenge shooting," June 4, 1982 - http://news.google.com/newspapers?

$\underline{\text { nid }=1345 \& \text { dat }=19820604 \& \mathrm{id}=\text { o-0vAAAAIBAJ } \& \text { sjid }=\text { YPkDAAAAIBAJ } \& p g=5984,12}$ $\underline{70148}$

2. Associated Press published in The Daily Collegian, "Israeli invasion pushes guerrillas from stronghold,” June 9, 1982. http://digitalnewspapers.libraries.psu.edu/Repository/ DCG/1982/06/09/036-DCG-1982-06-09-001-SINGLE.pdf

3.The Associated Press, archive, June 8, 1982.

4. Marcus Eliason, AP archives, "Israel's Two War Leaders Unlikely Partners," June 9, 1982.

5. Nicolas B. Tatro, AP appeared in The International Coalition for Missing Israeli Soldiers, "Syrians Parade Israeli Tank Through Damascus,” June 11, 1982. http:// www.mia.org.il/articles.html

6. Barton Reppert, AP accessed through LexNexis, "Opposition To Israeli Action Forming In Congress," June 11, 1982.

7. Michael Goldsmith, AP archives, June 22, 1982.

8. Farouk Nassar, AP archives, June 23, 1982.

9. AP story accessed in LexisNexis; Also see: Amir Oren, Ha'aretz, "1982 memo shows Israel learned little from first Lebanon War,”Jul 12, 2009 - http://www.haaretz.com/ print-edition/features/1982-memo-shows-israel-learned-little-from-first-lebanonwar-1.279802 
10. George Gedda, AP archives, July 30, 1982.

11. Arthur Max, AP archives, "Israel Angry with War Critics," Aug. 7, 1982.

12. Charles J. Hanley, AP archives, “Lebanon Crisis Won't End With PLO Pullout,” Aug. $14,1982$.

13. AP published in New York Times, PLO Troops Begin Pullout in Beirut, Aug. 22, 1982. http://www.nytimes.com/1982/08/22/world/plo-troops-begin-pullout-in-beirutfrench-enter-city.html

14. The Associated Press, archives, Sept. 10, 1982.

15. Marcus Eliason, AP archives, "Gemayel Death Could be Third Israeli Setback in Lebanon," Sept. 15, 1982.

16. David Minthorn, AP archives, "Brezhnev Blames U.S. for Massacre, Urges U.N. Action, Sept. 20, 1982.

17. Larry Thorson, AP archives, “Defense minister with big ideas for Israel," Sept. 22, 1982.

18. Marcus Eliason, AP archives, Sept. 25, 1982.

19. AP archives, “Colonel Who Resigned Over War Speaks for First Time,” Sept. 1982.

20. Scheherezade Faramarzi, AP published in Philadelphia Inquirer, "Survivors: Israelis Watched Massacre,” Dec. 22, 1982.

21.Scheherezade Faramarzi, The Galveston Daily News, "Exporting Islamic fundamentalism to Lebanon, Nov. 6, 1982. http://www.newspapers.com/newspage/16609382/

22. Scheherezade Faramarzi, AP published in The Gettysburg Times, "Victims tell of terror shelling by battleship New Jersey," Feb. 14, 1984. 
23. Scheherezade Faramarzi, AP published in Tulsa World, "Cycle of Resentment Grows in Israeli-occupied Lebanon,” May 13, 1984.

24. AP archives, "EDITOR'S NOTE - THE FOLLOWING COPY WAS SUBMITTED TO THE ISRAELI,” June 16,1985. TEL AVIV EDITOR'S NOTE - The following copy was submitted to the Israeli military censor, who ordered significant deletions. http:// www.apnewsarchive.com/1985/EDITOR-S-NOTE-The-following-copy-was-submitted$\underline{\text { to-the-Israeli-military-censor-who-ordered-a-significant-deletions-/id-304c } 7 \mathrm{c} 3 \mathrm{eb} 2 \mathrm{e} 6 \mathrm{fb}-}$ $\underline{\mathrm{ca} 03 \mathrm{~d} 6 \mathrm{cb} 3 \mathrm{e} 49 \mathrm{ec} 6731}$

25. Edmond Shedid, AP archives, "Seven Wounded in Israel Copter Raid, 2 Killed in Tank Fire,” May. 4, 1993. http://www.apnewsarchive.com/1993/Seven-Wounded-In-Israeli-Copter-Raid-2-Killed-in-Tank-Fire/id-9b04ea2f7477bba5af8fe20fd04207be 26. AP archives, "Guerrillas Fire Katyusha Rockets on Northern Israel,” April 9, 1996. 27. AP published in Desert News, "Israelis Again Fire on Rebel Hub in Beirut," April 12, 1996. http://www.deseretnews.com/article/483092/ISRAELIS-AGAIN-FIRE-ON-

\section{REBEL-HUB-IN-BEIRUT.html?pg=all}

28. Barry Schweid, AP archives, "Christopher Works on Agreement to Halt IsraelHezbollah Conflict," April 15, 1996. http://www.apnewsarchive.com/1996/ChristopherWorks-on-Agreement-to-Halt-Israel-Hezbollah-Conflict/idd5ee2ce426cb3e7b1103ce545c5e01d8?SearchText=lebanon\%20April \%201996\%20hezbollah\%20israel\%20;Display 
29. Hussein Dakroub, The Brownsville Herald, "Israel-Hezbollah battles claim more lives in Lebanon,” April 16, 1996. http://newspaperarchive.com/us texas/brownsville/ brownsville-herald/1996/04-16/page-3

30. Jack Katzenell, AP archives, "Overwhelming public support for bombardment of Lebanon," April 16, 1996. http://newspaperarchive.com/us/texas/brownsville/ brownsville-herald/1996/04-16/page-3

31. Dianna Cahn, AP archives, "Israelis Flee Rocket Fire, But Strongly Support War," April 16, 1996.

32. Nicolas B. Tatro, AP archives, "U.S. Truce Proposals: International Monitoring and Syrian Guarantee," April 17, 1996. http://www.apnewsarchive.com/1996/U-S-TruceProposals-International-Monitoring-And-Syrian-Guarantee/id-ecf4922d8d05458c41da4e6c2a8e3ade?SearchText=lebanon\%20April\%201996\%20hezbollah\%20israel $\underline{\% 20 ; \text { Display }}$

33. Scheherezade Faramarzi, AP, “Israeli Arabs: Government doesn't protect us from rockets." April 17, 1996, http://www.apnewsarchive.com/1996/Israeli-Arabs-Government-Doesn-t-Protect-Us-from-Rockets/id-0c8ba8001532115d3049f10e087f8e3f? SearchText=Scheherezade\%20faramarzi $\% 201996 \% 20$ Arab\%20Israelis\%20shelters $\underline{\% 20 ; \text { Display }}$

34. Robert H. Reid, AP archives, "Pressure Mounts in Security Council for Cease-fire in Lebanon,” April 18, 1996.

35. Tarek al-Issawi, AP archives, "Israeli Aircraft Attack Apartment Building in Southern Lebanon, 11 Killed," April 18, 1996, http://www.apnewsarchive.com/1996/Israeli-Air- 
craft-Attack-Apartment-Building-in-Southern-Lebanon-11-Killed/

id-0af1bc2f474a8cd46a22dc5f803551d5

36. AP published in Arizona Daily Wildcat, "Israeli attack kills 75 UN refugees," April 19, 1996. http://wc.arizona.edu/papers/89/141/01_2_m.html

37. AP archives, “Chronology of Recent Fighting," April 19, 1996. http://www.apnewsarchive.com/1996/Chronology-of-Recent-Fighting/id-7608f3ed94a7e12aca9de9e540bddcba?SearchText=lebanon\%20April\%201996\%20hezbollah\%20israel $\underline{\% 20 ; \text { Display }}$

38. Dafna Linzer, News Press, April 21, 1996. http://archives.savannahnow.com/ sav_pdf_archive/text/ fr147/A_2323472.pdf

39. Sam F. Ghattas, AP archives, "Christopher in Lebanon, Israeli Warplanes, Gunboats in Action,” April 24, 1996. http://www.apnewsarchive.com/1996/Christopher-InLebanon-Israeli-Warplanes-Gunboats-In-Action/idac712413140aa0068461a6312b7a5c05?SearchText=lebanon\%20April \%201996\%20hezbollah\%20israel\%20;Display_

40. Hilary Appelman, AP archives, "Israelis Say Fighting to Prevent New Tragedy,” April $25,1996$.

41. Louis Meixler, AP archives, "UN General Assembly Condemns Israeli Attack on Civilians in Lebanon," April 26, 1996. http://www.apnewsarchive.com/1996/U-N-General-Assembly-Condemns-Israeli-Attack-on-Civilians-in-Lebanon/idef6ad8298d968f103c7ce9727f26198a?SearchText=lebanon\%20April \%201996\%20hezbollah\%20israel\%20;Display_ 
42. Tarek Al-Issawi, South Coast Today, "Lebanese refugees go home.” Saturday April 28, 1996. http://www.southcoasttoday.com/apps/pbcs.dll/article?AID=/19960428/

\section{$\underline{\text { NEWS/304289998 }}$}

43. Robert H. Reid, AP archives, "Israel's Artillery Commander Denies UN Camp was Targeted," May 6, 1996. http://www.apnewsarchive.com/1996/Israel-s-Artillery-Commander-Denies-U-N-Camp-Was-Targeted/id-b31cdd71ba2242d2a6dd1d903f864bf3

44. AP published in Los Angeles Times, "Videotape Supports Claims Israel Targeted UN Base,” May 7, 1996. http://articles.latimes.com/1996-05-07/news/mn-1404_1_u-n-base

45. Nicolas B. Tatro, AP archives, "Peres Says UN Report One-sided, Israel Releases Own Video," May 8, 1996. http://www.apnewsarchive.com/1996/Peres-Says-U-N-Report-One-Sided-Israel-Releases-Own-Video/id-093623e23748028d9a3fa8d88e3d0fc1? SearchText=lebanon\%20April\%201996\%20hezbollah\%20israel\%20;Display 46. Nicolas B. Tatro, AP archives, "Israel Blames Peacekeepers for Contributing to Qana Shelling Tragedy,” May 15, 1996. http://www.apnewsarchive.com/1996/Israel-BlamesPeacekeepers-For-Contributing-To-Qana-Shelling-Tragedy/id-6e66bec43ff9d55ffc84718eaba3061d?SearchText=lebanon\%20April\%201996\%20hezbollah\%20israel $\underline{\% 20 ; \text { Display }}$

47. Scheherezade Faramarzi, AP archives, "Rabbis and Sheiks," June 10, 1996. 48. Ahmed Mantash, AP published in South Coast Today, "Guerrillas gloat over slain Israelis," Sept. 6, 1997. http://www.southcoasttoday.com/apps/pbcs.dll/article?AID=/ 19970906/NEWS/309069921\&emailAFriend $=1$ 
49. George Jahn, Associated Press archives, “Officials: Tubing may have Iraq link,” Sep. 18, 2002. http://www.apnewsarchive.com/2002/Officials-Tubing-May-Have-Iraq-Link/ id-77ece27e01da699ca7ea4db69245d5de? SearchText=george\%20jahn\%20Iraq\%20alu$\underline{\text { minum } \% 20 \text { tubes } \% 202002 ; \text { Display }}$

50. Scheherezade Faramarzi, AP published on Jacksonville.com, "Jittery U.S. soldiers firing in the dark kill six Iraqis trying to get home before curfew," August 10, 2003.http://jacksonville.com/tu-online/apnews/stories/081003/D7SR8BVG5.html 51. Scheherezade Faramarzi, AP published on $C B S$ Website, "Palestinians' Rage At U.S. Festers ," April 23, 2004 - http://www.cbsnews.com/news/palestinians-rage-at-us-fes$\underline{\text { ters/ }}$

52. Scheherezade Faramarzi, Associated Press, May 20, 2004, “U.S. Aircraft Reportedly Kills 40 Iraqis" -http://www.fpp.co.uk/online/04/05/Iraq_wedding_massacre.html 53. Scheherezade Faramarzi, Associated Press, May 21, 2004,’'Iraqi survivors recount US tent shelling after wedding party"- http://www.boston.com/news/world/middleeast/articles/2004/05/21/iraqi_survivors_recount_us tent_shelling_after_wedding_party/ 54. Anthony Deutsch, AP published in Spartanburg Herald-Journal, "No wedding at border, says military: Evidence: Military binoculars, guns and passports,” May 23, 2004. http://news.google.com/newspapers?

$\underline{\text { nid }=1876 \& \text { dat }=20040523 \& \text { id=zz0fAAAAIBAJ\&sjid=ZNAEAAAAIBAJ } \& p g=6847,32}$ $\underline{33021}$

55. Scheherezade Faramarzi, May 24, 2004, "Video Contradicts US Military, Shows Iraq Wedding Celebration" - http://www.commondreams.org/headlines04/0524-02.htm 
56. Scheherezade Faramarzi, May 25, 2004, "Photos may show U.S. attacked safe house, not wedding" - http://airwolf.lmtonline.com/news/archive/052504/pagea8.pdf

57. Joseph Panossian, AP published in Desert News, "Hezbollah captures 2 Israeli soldiers in clashes, sparking Israeli offensive into Lebanon," July 12, 2006. http://www.de$\underline{\text { seretnews.com/article/640194197/Hezbollah-captures-2-Israeli-soldiers-in-clashes- }}$ sparking-Israeli-offensive-into-Lebanon.html?pg=all

58. Steven Gutkin, AP published in NBC News, "Crisis allows Israel to pursue strategic goals, July 13, 2006. http://www.nbcnews.com/id/13847803/ns/world_news-mideast$\underline{\mathrm{n} \_ \text {africa/t/crisis-allows-israel-pursue-strategic-goals/\#.U8rpioBdUUd. }}$.

59. Ravi Nessman, AP published in Southeast Missourian, "Israeli troops raid Lebanon," Jul 13, 2006. http://www.semissourian.com/story/1160085.html 60. AP published AP published in on Fox News "Israel: No Targets in Lebanon Are Immune," July 13, 2006, http://www.foxnews.com/printer_friendly_wires/ $\underline{\text { 2006Jul13/0,4675,IsraelLebanonMilitary,00.html }}$

61. Steven Gutkin, AP published in Washington Post, "Israel PM's Bid to Free 3 Soldiers a Gamble," July 14, 2006. http://www.washingtonpost.com/wp-dyn/content/article/ $\underline{2006 / 07 / 14 / A R 2006071401348 ~ p f . h t m l ~}$

62. Sam F. Ghattas, AP published in on Katu.com. "Israel continues to punish Lebanon, hits fuel supply,” Jul 14, 2006. http://www.katu.com/news/3632791.htm 63. Hamza Hendawi and Lee Keath, AP story published in Freedom Republic, "Israel sends ground forces into Lebanon," July 17, 2006. http://www.freerepublic.com/focus/f$\underline{\text { news } / 1667025 / \text { posts }}$ 
64. AP published in military.com, "Israel Answers Attacks," July 17, 2006. http://www.military.com/NewsContent/0,13319,105739,00.html?ESRC=eb.nl

65. AP published on Fox News, "Hezbollah Rocket Attack Kills Two in Nazareth,” July 19, 2006.

66. Donna Abu Nasr, AP published in Washington Post, "Famed Beirut nightlife shows resilience,”July 22, 2006. http://www.washingtonpost.com/wp-dyn/content/article/ 2006/07/22/AR2006072200543 pf.html

67. AP archives, "Israel-Wrong Nasrallah,” Jul 22, 2006.

68. Associated Press, AP published in USA Today, "Battles continue; Israel warns people to leave south Lebanon,” Jul 21, 2006. http://usatoday30.usatoday.com/news/world/ 2006-07-20-israel-lebanon_x.htm

69. Sally Buzbee, AP published in Desert News, "News analysis: Fighting could tip balance toward extremists," July 23, 2006. http://www.deseretnews.com/article/640196964/ Fighting-could-tip-balance-toward-extremists.html?pg=all

70. Charles J. Hanley, AP published in Washington Post, "2 Key Americans See 1982 in Lebanon '06," July 23, 2006. http://www.washingtonpost.com/wp-dyn/content/article/ 2006/07/23/AR2006072300210.html

71. Scheherezade Faramarzi, AP published in Washington Post, "Hezbollah Says Israeli Response a Surprise," July 25, 2006. http://www.washingtonpost.com/wp-dyn/content/ article/2006/07/25/AR2006072500974.html

72. Ravi Nessman, AP archives, “Mideast Fighting,” Jul 28, 2006.

73. Hamza Hendawi, AP, “Israel Targeting Hezbollah Infrastructure,” Jul 26, 2006. 
74. Ravi Nessman, AP published in Free Republic, "Israel OKs call-up of 30,000 reservists, Jul 27, 2006. http://www.freerepublic.com/focus/f-news/1673413/posts

75. Sally Buzbee, AP published in USA Today, "In guerrilla war, Hezbollah may have an edge, Jul 30, 2006. http://30.usatoday.com/news/world/2006-07-30-hezbollah-analy$\underline{\text { sis X.htm }}$

76. Matti Friedman, AP published in Washington Post, "Plumbers Come to Rescue in Israeli Shelter," July 31, 2006;. http://www.washingtonpost.com/wp-dyn/content/article/ 2006/07/27/AR2006072701046 pf.html

77. Aron Heller, AP published in Washington Post, "Northern Israelis Adapt to Life Under Fire,” July 31, 2006. http://www.washingtonpost.com/wp-dyn/content/article/ 2006/07/31/AR2006073100540.html

78. Hussein Dakroub, AP archives, "Israel sends armored troops into Lebanon," Aug. 1, 2006.

79. Scheherezade Faramarzi, AP published in Washington Post, "Hezbollah's Fight Impresses Supporters," August 2, 2006. http://www.washingtonpost.com/wp-dyn/content/ article/2006/08/02/AR2006080200362_pf.html

80. Scheherezade Faramarzi, AP archives, "Night of Death,” Aug. 3, 2006.

81. AP published on Fox News, "Israeli Forces Battle Hezbollah in Tyre, Launch Multiple Airstrikes Across Country, Aug. 5, 2006. http://www.foxnews.com/story/2006/08/05/ israeli-forces-battle-hezbollah-in-tyre-launch-multiple-airstrikes-across/ 
82. Aron Heller, AP published in Irish Examiner, "Israel suffers deadliest attack as rockets kill 15,” August 7, 2006. http://www.irishexaminer.com/world/israel-suffers-deadliest-attack-as-rockets-kill-15-10244.html

83. Anne Gearan, AP published in South Coast Today, "Deal to end fighting won't help U.S. image,” Aug. 13, 2006. http://www.southcoasttoday.com/apps/pbcs.dll/article? $\underline{\mathrm{AID}=/ 20060813 / \mathrm{NEWS} / 308139977 \& \mathrm{cid}=\text { sitesearch }}$

84. Kathy Gannon, AP published in Washington Post, "Lebanese Find Destruction Back Home," Aug. 14, 2004. http://www.washingtonpost.com/wp-dyn/content/article/ 2006/08/14/AR2006081400821_pf.html

85. Steven Gutkin, AP published in Washington Post, "When Will Be Next Mideast War?” Aug 14, 2006. http://www.washingtonpost.com/wp-dyn/content/article/ 2006/08/14/AR2006081400721.html

86. AP published in Washington Post, "Mideast War, by the Numbers," Aug. 17, 2006. http://www.washingtonpost.com/wp-dyn/content/article/2006/08/17/ $\underline{\text { AR2006081700909_pf.html }}$

87. Scheherezade Faramarzi, AP published in Roth Army, "Hezbollah puts down deep roots,” Aug. 21, 2006. http://www.rotharmy.com/forums/archive/index.php?t-39537.html 88. Todd Pitman, AP published in Washington Post, "Lebanese Father Mourns Loss of Family," Aug. 29, 2006. http://www.apnewsarchive.com/2006/Lebanese-Father-MournsLoss-of-Family/id-e1d3f2e7ca6b594bc91988310e5d4f65?SearchText=\%20marwaheen \%202006; Display 
89. AP published on Fox News, "Haifa Man Dies From Lebanon War Wounds," Aug. 31, 2007. http://www.foxnews.com/printer friendly wires/2007Aug31/0,4675,BRFIsraelWarFatality,00.html

90. AP, "Saving animals through 40 days \& nights of war in Lebanon \& Israel, September 2006. http://www.animalpeoplenews.org/06/09/tsg.savinganimals09.06.htm.

91. Hamza Hendawi, AP, Nasrallah's Popularity Climbs, Sept. 25, 2006. http://www.apnewsarchive.com/2006/Nasrallah-s-Popularity-Climbs/id$\underline{\text { da048352fd04c1028ed08a9a34ffb1db }}$

92. Hamza Hendawi, AP published in Washington Post, "U.N.-Israel Encounter Highlights Discord," Sept. 29, 2006. http://www.washingtonpost.com/wp-dyn/content/article/ 2006/09/29/AR2006092900986 pf.html

93. Scheherezade Faramarzi, AP on Highbeam Business, "Iran stands as a power in Mideast,” Dec. 10, 2006. http://business.highbeam.com/435553/article-1G1-155721246/ iran-stands-power-mideast

94. Sam F. Ghattas, AP archives, "Lebanon Sees More Than 1,ooo War Deaths, Dec. 28, 2006.

95. Jim Krane, AP, March 24, 2007, AP published in The St. Augustine Record, "Iranian forces seize 15 U.K. sailors, marines,"

96. AP published on Fox News, "Haifa Man Dies From Lebanon War Wounds," Aug. 31, 2007. http://www.foxnews.com/printer_friendly_wires/2007Aug31/0,4675,BRFIsraelWarFatality,00.html 
97. Kim Gamel, AP published in USA Today, Feb. 28, 2008, "US mil: Iraqi killed north of Baghdad" - http://usatoday30.usatoday.com/news/world/2008-02-28-1394763717_x.htm 98. George Jahn, “AP EXCLUSIVE: GRAPH SUGGESTS IRAN WORKING ON BOMB," Nov. 27, 2012. http://bigstory.ap.org/article/ap-exclusive-graph-suggests-iran$\underline{\text { working-bomb }}$ 99. Associated Press, "Social Media Guidelines for AP Employees," May 2013. http:// www.ap.org/Images/Social-Media-Guidelines_tcm28-9832.pdf

100. https://www.facebook.com/pages/Associated-Press/109042952456316? group id=0\# 